\title{
12. SITE 313: MID-PACIFIC MOUNTAINS
}

\author{
The Shipboard Scientific Party ${ }^{1}$
}

\section{SITE DATA}

Date Occupied: 3 October 1973 (1133)

Date Departed: 6 October 1973 (1815)

Time on Site: 78.7 hours

Position: $20^{\circ} 10.52^{\prime} \mathrm{N}, 170^{\circ} 57.15^{\prime} \mathrm{W}$

Water Depth: 3484 corrected meters (echo sounding)

Bottom Felt With Drill Pipe At: 3492 meters below rig floor

Penetration: 606 meters

Number of Holes: 1

Number of Cores: 44

Total Length of Cored Section: 394.5 meters

Total Core Recovered: 220.5 meters

\section{BACKGROUND AND OBJECTIVES}

After more than a day at Site 312 of waiting for the swell and seas to subside, with no more of the drill string but the bottom-hole assembly hanging below the rig floor, it became apparent that not enough drilling time remained on Leg 32 for us to reach our objective of dating the crust at anomaly M-2. Also, because of the great depth of water and the near certainty that there would be slow drilling and coring in the cherts and turbidites expected, we expected no more than a marginal chance for enough time to attain our secondary objectives of recording the equatorial passage of the Pacific plate or of recovering many cores for biostratigraphic and sedimentological study. In fact, it was possible that the usual shallow subbottom reflector shown on the 12$\mathrm{kHz}$ record would prohibit our spudding in at all, even though the airgun record showed less shallow reflectors there than at any other place along our track. A $3.5-\mathrm{kHz}$ profiler would have been very useful for comparison of the uppermost acoustic reflectors present at Site 311 versus Site 312.

'Roger L. Larson, Lamont-Doherty Geological Observatory, Palisades, New York (Co-chief scientist); Ralph Moberly, Hawaii Institute of Geophysics, Honolulu, Hawaii (Co-chief scientist); David Bukry, U.S. Geological Survey, La Jolla, California; Helen P. Foreman, Oberlin College, Oberlin, Ohio; James V. Gardner, Scripps Institution of Oceanography, La Jolla, California; John B. Keene, Scripps Institution of Oceanography, La Jolla, California; Yves Lancelot, Lamont-Doherty Geological Observatory, Palisades, New York; Hanspeter Luterbacher, Esso Production Research-European, Begles, France; Monte C. Marshall, U. S. Geological Survey, Menlo Park, California; Albert Matter, Universitat Bern, Bern, Switzerland.

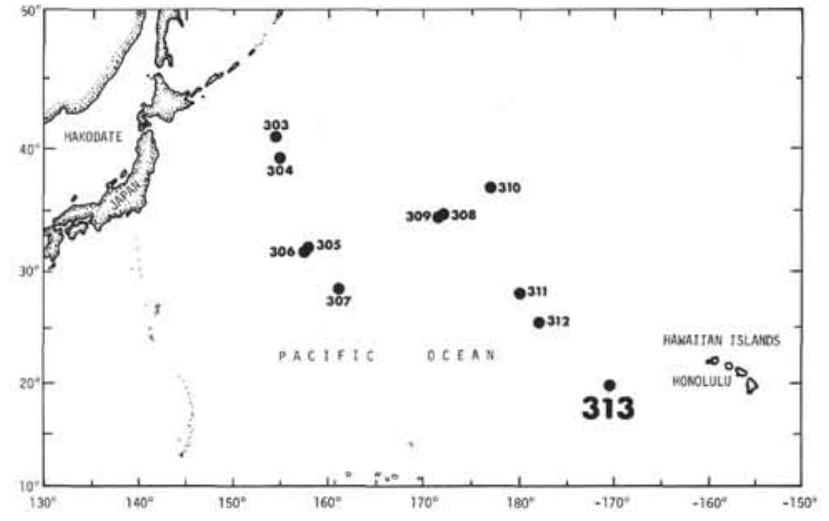

So we were faced with the problem of how best to utilize the 4 days of drilling time remaining. A conversation with staff at DSDP headquarters indicated that although a 2-day early arrival in Honolulu could be used effectively in the shipyard, any earlier arrival could not be so used. Because Leg 32 had expected to end at Midway Islands and was only changed to Honolulu shortly before departure, and because our high priority sites in the western Pacific were expected to take all of our scheduled time, we had not selected any contingency sites between Midway and Honolulu. We did not have enough time to drill the first site of Leg 33, near Johnston Island, as it was to be continuously cored in deep water and needed some additional travel time to reach it.

We had four general possibilities for sites: (1) deepwater sites north or south of the Hawaiian Archipelago, (2) shallow to deep sites along the Hawaiian Ridge, (3) shallow to deep sites along the northeastern Mid-Pacific Mountains, and (4) shallow sites along Necker Ridge. Factors such as the expected poor preservation of fossils, the time of wire-line trips for retrieving cores, and the fact that there would be no magnetic anomalies for extending a basement date to other areas caused us to reject deep-water sites. The general theme of Leg 32, Mesozoic history, argued against any Hawaiian site, which would be virtually certain to be mainly Neogene detritus over sparsely fossiliferous Mesozoic. The shallow depth, tectonic interest, and position on our direct route made Necker Ridge attractive, but it lacked much sediment. The Mid-Pacific Mountains had been drilled at Horizon Guyot (Site 171), but the pre-Maestrichtian record there contained considerable volcanic material, including a lava flow, and a friable shallow-water calcarenite that could not be well dated.

In view of the overall leg objectives, we decided to drill a site in the Mid-Pacific Mountains, concentrating our coring effort on the pre-Maestrichtian section. Site 
171 was at 2300 meters depth, and we wanted a somewhat deeper site that could be expected to have planktonic fossils to record its earlier history. A deeper site might allow us to reach the broad, irregular basement ridge on which the seamounts and guyots of the MidPacific Mountains sit. Besides these Mesozoic interests, we intended to sample the Paleogene. In Core 9 of Site 171, middle Eocene lies unconformably on midMaestrichtian, but a site in a basin might preserve the Paleogene.

A basin a few tens of $\mathrm{km}$ in diameter lies near $20^{\circ} \mathrm{N}$, $171^{\circ} \mathrm{W}$ with its floor near 3500 meters. It is surrounded on the south and east by seamounts, perhaps guyots, that rise to 1200 meters, and on the west by one that rises to 2000 meters. The basin appears to be open to the north, at 3750 meters depth. Tracks of the Scripps Institution of Oceanography expeditions Circe and Scan, as well as Glomar Challenger Leg 6, cross the basin. We chose a site (Figure 1) at 1700 on 17 May 1969 of the Scan-3 track as being most likely to meet our objectives within the time available.

\section{OPERATIONS}

After abandoning Site 312 because there was not enough time remaining to achieve the primary objective at that location, we steamed east-southeast to a shallowwater site at the northern edge of the Mid-Pacific Mountains. This is a valley between several volcanic peaks that holds $0.5 \mathrm{sec}$ of relatively flat-lying sediments. We aimed for $20^{\circ} 11.7^{\prime} \mathrm{N}, 170^{\circ} 58.1^{\prime} \mathrm{W}$, which was crossed by the Argo on expedition Scan at 1730, 17 May 1969. As our approach was along an azimuth close to that of the

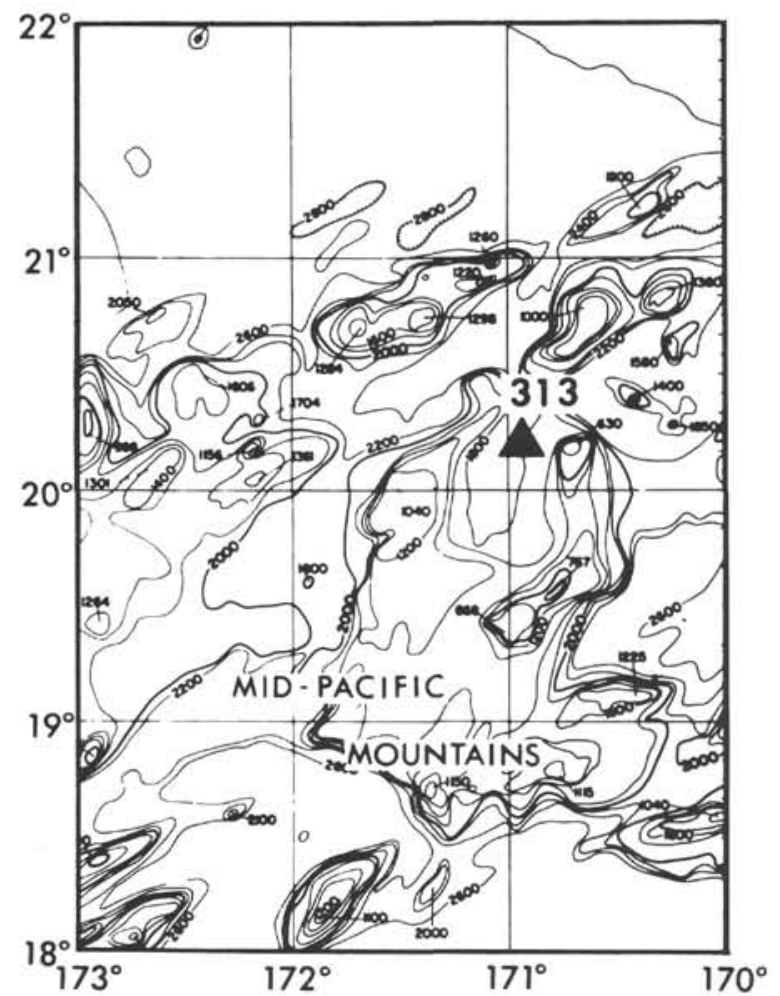

Figure 1. Bathymetry in the regton of Site 313 (after Chase et al., 1971). Contour interval $200 \mathrm{fm}$ uncorrected.
Scan line, we did not feel a detailed survey of the site was necessary. At 1030Z, 3 October 1973, we crossed the potential site location in the middle of the basin. We continued beyond the site until $1105 \mathrm{Z}$, when we made a wide turn to port to reverse course and take us back to the center of the basin. At $1124 \mathrm{Z}$ we slowed to 5 knots in preparation for the beacon drop (Figures 2 and 3 ). At $1133 \mathrm{Z}$ on 3 October 1973, we dropped a presoaked beacon on the run in 1862 uncorrected fm ( $3494 \mathrm{~m}$, corrected to the rig floor). At about $1200 \mathrm{Z}$ we began to run in pipe in a calm sea with a light breeze.

A sonobuoy was run on station on 6 October 1973.

We left Site 313 by heading slowly west-southwest, streaming the running gear, turning, and coming back across the site heading east-northeast for Honolulu (Figure 3).

We reached the sea floor with the drilling assembly 8 $\mathrm{hr}$ after starting to run in pipe at this site. An indication of bottom contact occurred at 3492 meters, 2 meters above the corrected PDR depth. An 8.5-meter core was cut that contained 8.0 meters of sediment. The sediment at the sea floor proved to be soft, and we spudded in the drilling assembly with no problems. For each four lengths of drill pipe, we drilled three and cored the fourth down to 150 meters where we encountered the Eocene with Core 5. From 150 to 250 meters were continuously cored in an attempt to recover all of the Eocene-Paleocene sediment at this site. When the Maestrichtian was encountered in Core 15 at 240 meters, we began to recover every other core, as the Maestrichtian to Campanian is known for this area from Horizon Guyot. Cores 15 through 19 are all in the same Maestrichtian zone, so we began coring every fourth length of drill pipe with Core 20. This was continued until Core 22, which encountered a very hard layer at 398 meters. We recovered a partial Core 22 that consisted of calcareous porcellanite. The formation be-

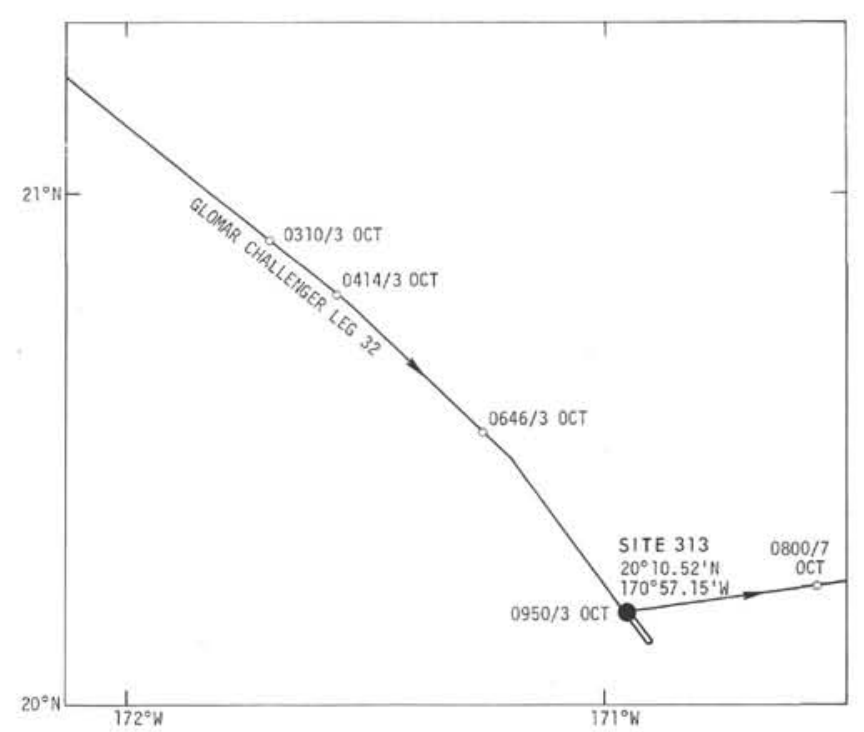

Figure 2. Track chart in vicinity of Site 313. Navigation points indicated by open circles and annotated time/daymonth. 


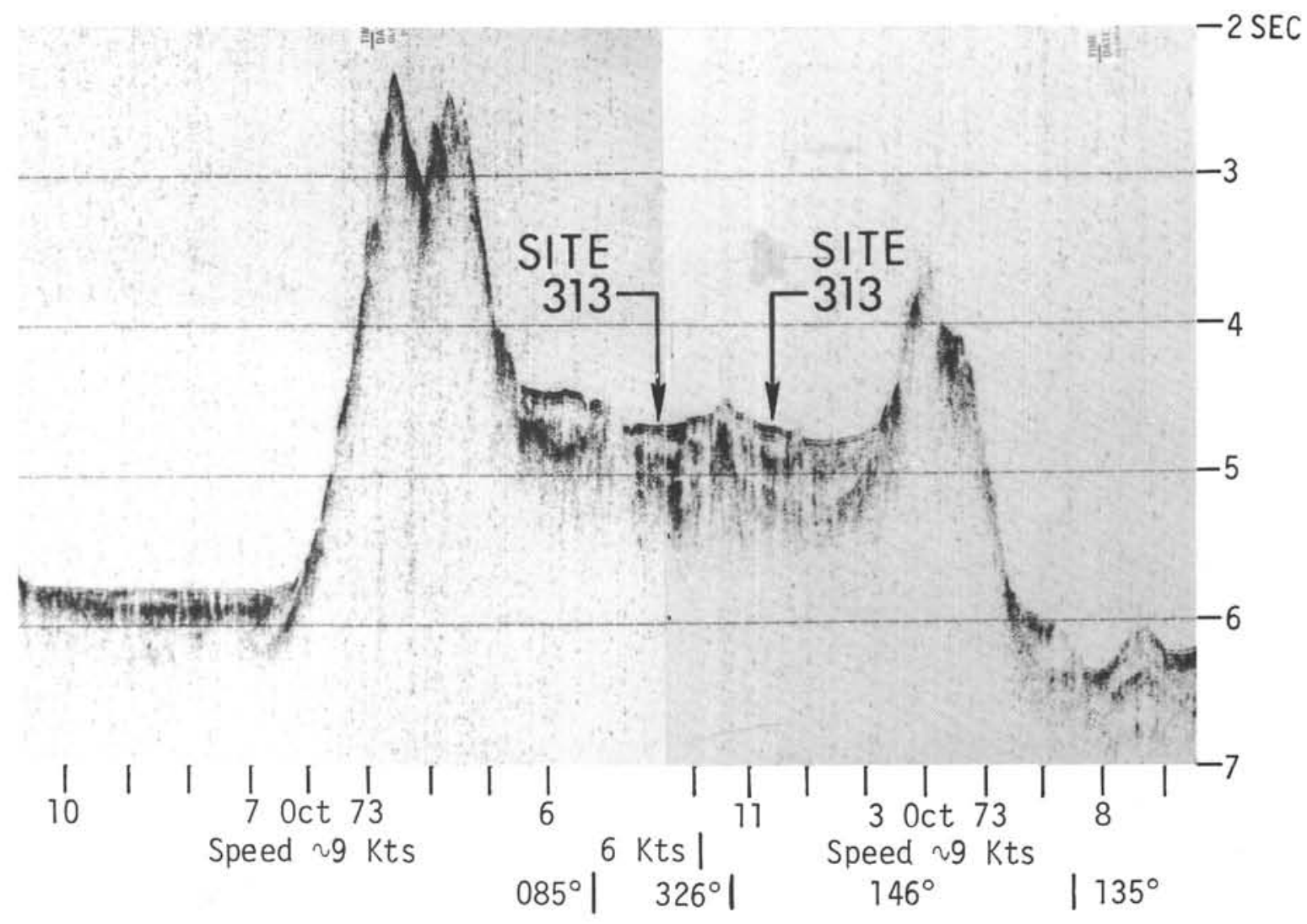

Figure 3. Seismic profiler sections approaching and leaving Site 313.

neath also appeared to be well lithified, so we began continuous coring at 398 meters. This was continued to the bottom of the hole at 606 meters through a sequence of late Campanian volcanic and calcareous turbidites. This formation was well lithified and stood up well during the coring process, so that about $50 \%$ of it was recovered. We had trouble several times around Core 30 pulling the inner core barrel free from the drilling assembly. The overshot would hook onto the core barrel with no problem, but several $10,000-1 b$ tugs would then be necessary to start the core barrel up the pipe. The cause of this trouble was not discovered.

Basalt that we assume to be basement was recovered in Cores 43 and 44 . There was not a distinct break in the drilling rate to indicate the basement contact, although the last half of Core 43 drilled more slowly and with more vibration than the first half. The last 3 meters of Core 44 drilled through very quickly as though we had punched through the bottom of a sill or flow. Nothing but basalt was recovered, although this could have resulted from excessive pump pressure washing away a softer, underlying formation. The textural characteristics of the lower recovered portion of Core 44 will be examined closely to determine if the material is intrusive or extrusive. A summary of the coring data appears in Table 1.

\section{LITHOLOGIC SUMMARY}

The stratigraphic section drilled at Site 313 was continuously cored for the intervals 149.5 to 251 meters (Cores 5 through 16) and 397 to 606 meters (Cores 22 through 44), and intermittently cored at other intervals. At 594 meters (Core 43) basalt was encountered and the hole was terminated in basalt at 606 meters (Core 44). The water depth at this site was 3492 meters.

The recovery was relatively good in all cores with the exception of Cores $6,8,10,11$, and 14 wherein mainly chert fragments were recovered.

The composition of selected lithologies is shown in the smear slide summary (Table 2).

The section can be divided into two sedimentary units overlying an igneous unit.

Unit 1 -Foram-nanno ooze becoming chalk and containing chert below 149.5 meters (Core 5) and with minor amounts of radiolarian-nanno ooze and zeoliticnanno ooze (mostly turbidites) (Cores 1 through 22, 0 $400 \mathrm{~m})$.

Unit 2-Foram-nanno limestone, calcareous volcanic sandstone, siltstone, and breccia and calcareous claystone (turbidite sequence) (Cores 23 through 42, 400-594 m).

Unit 3-Basalt (Cores 43 and 44, 594-606 m).

\section{Unit 1-Ooze, Chalk, and Chert (Cores 1 through 22)}

This unit extends from the ocean floor down to a depth of 400 meters where the first greenish-black volcanic sandstone was recovered.

Core $1(0-8 \mathrm{~m})$ contained a yellowish-brown zeolitic nanno ooze and, although badly disturbed by drilling, some deposition by turbidites can be recognized. There are minor layers $(<10 \mathrm{~cm})$ of foram-nanno ooze and 
TABLE 1

Coring Summary

\begin{tabular}{|c|c|c|c|c|c|c|c|}
\hline Core & $\begin{array}{l}\text { Date } \\
\text { (Oct. } \\
1973 \text { ) }\end{array}$ & Time & $\begin{array}{l}\text { Depth From } \\
\text { Drill Floor } \\
\text { (m) }\end{array}$ & $\begin{array}{l}\text { Depth Below } \\
\text { Sea Floor } \\
\text { (m) }\end{array}$ & $\begin{array}{l}\text { Length } \\
\text { Cored } \\
\text { (m) }\end{array}$ & $\begin{array}{l}\text { Length } \\
\text { Recovered } \\
\text { (m) }\end{array}$ & $\begin{array}{c}\text { Recovery } \\
\text { (\%) }\end{array}$ \\
\hline 1 & 3 & 0930 & $3492.0-3500.0$ & $0.0-8.0$ & 8.0 & 8.0 & 100 \\
\hline 2 & 3 & 1045 & $3527.5-3537.0$ & $35.5-45.0$ & 9.5 & 3.5 & 37 \\
\hline 3 & 3 & 1235 & $3565.5-3575.0$ & $73.5-83.0$ & 9.5 & 8.8 & 93 \\
\hline 4 & 3 & 1405 & $3603.5-3613.0$ & $111.5-121.0$ & 9.5 & 8.9 & 94 \\
\hline 5 & 3 & 1525 & $3641.5-3651.0$ & $149.5-159.0$ & 9.5 & 9.5 & 100 \\
\hline 6 & 3 & 1735 & $3651.0-3660.0$ & $159.0-168.0$ & 9.0 & 0.3 & 3 \\
\hline 7 & 3 & 1910 & $3660.0-3669.0$ & $168.0-177.0$ & 9.0 & 8.1 & 90 \\
\hline 8 & 3 & 2045 & $3669.0-3678.5$ & $177.0-186.5$ & 9.5 & 0.1 & 1 \\
\hline 9 & 3 & 2205 & $3678.5-3681.0$ & $186.5-189.0$ & 2.5 & 0.9 & 36 \\
\hline 10 & 3 & 2320 & $3681.0-3687.5$ & $189.0-195.5$ & 6.5 & 0.1 & 1 \\
\hline 11 & 4 & 0040 & $3687.5-3697.0$ & $195.5-205.0$ & 9.5 & 0.1 & 1 \\
\hline 12 & 4 & 0150 & $3697.0-3706.0$ & $205.0-214.0$ & 9.0 & 6.5 & 72 \\
\hline 13 & 4 & 0255 & $3706.0-3715.0$ & $214.0-223.0$ & 9.0 & 9.5 & 105 \\
\hline 14 & 4 & 0410 & $3715.0-3724.5$ & $223.0-232.5$ & 9.5 & 0.1 & 1 \\
\hline 15 & 4 & 0520 & $3724.5-3734.0$ & $232.5-242.0$ & 9.5 & 5.5 & 58 \\
\hline 16 & 4 & 0630 & $3734.0-3743.0$ & $242.0-251.0$ & 9.0 & 7.0 & 78 \\
\hline 17 & 4 & 0745 & $3752.5-3762.0$ & $260.5-270.0$ & 9.5 & 6.5 & 68 \\
\hline 18 & 4 & 0900 & $3771.5-3781.0$ & $279.5-289.0$ & 9.5 & 7.6 & 79 \\
\hline 19 & 4 & 1010 & $3790.5-3800.0$ & $298.5-308.0$ & 9.5 & 9.5 & 100 \\
\hline 20 & 4 & 1150 & $3828.5-3838.0$ & $336.5-346.0$ & 9.5 & 3.9 & 41 \\
\hline 21 & 4 & 1350 & $3866.5-3876.0$ & $374.5-384.0$ & 9.5 & 7.5 & 79 \\
\hline 22 & 4 & 1545 & $3889.0-3892.0$ & $397.0-400.0$ & 3.0 & 3.0 & 100 \\
\hline 23 & 4 & 1730 & $3892.0-3901.5$ & $400.0-409.5$ & 9.5 & 0.5 & 5 \\
\hline 24 & 4 & 1930 & $3901.5-3911.0$ & $409.5-419.0$ & 9.5 & 7.6 & 80 \\
\hline 25 & 4 & 2110 & $3911.0-3920.5$ & $419.0-428.5$ & 9.5 & 5.1 & 54 \\
\hline 26 & 4 & 2240 & $3920.5-3930.0$ & $428.5-438.0$ & 9.5 & 1.9 & 20 \\
\hline 27 & 5 & 0040 & $3930.0-3939.5$ & $438.0-447.5$ & 9.5 & 3.1 & 33 \\
\hline 28 & 5 & 0230 & $3939.5-3949.0$ & $447.5-457.0$ & 9.5 & 5.0 & 53 \\
\hline 29 & 5 & 0400 & $3949.0-3958.0$ & $457.0-466.0$ & 9.0 & 5.2 & 58 \\
\hline 30 & 5 & 0645 & $3958.0-3967.5$ & $466.0-475.5$ & 9.5 & 4.4 & 46 \\
\hline 31 & 5 & 0845 & $3967.5-3977.0$ & $475.5-485.0$ & 9.5 & 6.6 & 69 \\
\hline 32 & 5 & 1030 & $3977.0-3986.5$ & $485.0-494.5$ & 9.5 & 4.1 & 43 \\
\hline 33 & 5 & 1205 & $3986.5-3996.0$ & $494.5-504.0$ & 9.5 & 2.8 & 29 \\
\hline 34 & 5 & 1340 & $3996.0-4005.5$ & $504.0-513.5$ & 9.5 & 4.7 & 49 \\
\hline 35 & 5 & 1540 & $4005.5-4015.0$ & $513.5-523.0$ & 9.5 & 7.2 & 76 \\
\hline 36 & 5 & 1710 & $4015.0-4024.5$ & $523.0-532.5$ & 9.5 & 6.1 & 64 \\
\hline 37 & 5 & 1855 & $4024.5-4034.0$ & $532.5-542.0$ & 9.5 & 9.5 & 100 \\
\hline 38 & 5 & 2055 & $4034.0-4043.0$ & $542.0-551.0$ & 9.0 & 4.5 & 50 \\
\hline 39 & 5 & 2230 & $4043.0-4052.0$ & $551.0-560.0$ & 9.0 & 5.2 & 58 \\
\hline 40 & 6 & 0010 & $4052.0-4061.0$ & $560.0-569.0$ & 9.0 & 4.5 & 50 \\
\hline 41 & 6 & 0220 & $4061.0-4070.5$ & $569.0-578.5$ & 9.5 & 6.6 & 69 \\
\hline 42 & 6 & 0415 & $4070.5-4080.0$ & $578.5-588.0$ & 9.5 & 4.5 & 47 \\
\hline 43 & 6 & 0605 & $4080.0-4089.0$ & $588.0-597.0$ & 9.0 & 1.9 & 21 \\
\hline 44 & 6 & 0815 & $4089.0-4098.0$ & $597.0-606.0$ & 9.0 & 4.6 & 51 \\
\hline Total & & & & & 394.5 & 220.5 & 55.9 \\
\hline
\end{tabular}

these are a paler shade of color. The zeolite phillipsite is common in the finer darker layers and is often twinned, although the crystal outline is ragged. Individual crystals are generally less than $50 \mu \mathrm{m}$.

In Core $2(35.5-45 \mathrm{~m})$ radiolarians become abundant below Section 3 and the nanno ooze becomes a radiolarian nanno ooze. In Cores 3 and 4 (73.5-83 m, 111.5$121 \mathrm{~m}$ ) nanno ooze again becomes the dominant lithology.

The first chert and chalk were recovered from the upper part of Core 5 (149.5-159 m). The chert was banded (3-4 $\mathrm{mm})$ brown and gray, vitreous, and with conchoidal fractures. The rounded surfaces on the chert with at- tached calcareous material indicate its nodular nature. The nanno chalk in Core 5 contained a minor amount of volcanic sand-size material, was cross-bedded and laminated, and represented part of a turbidite. Bioturbation is common in the chalk layers which are interbedded with softer nanno ooze. Interbedded nanno ooze and chalk also occur in Core $6(159-168 \mathrm{~m})$. In Core 5 a zeolite (clinoptilolite) occurs in darker layers as clear prismatic crystals $(30-40 \mu \mathrm{m})$.

The remainder of the first continuously cored interval (Cores 7 through 16) consisted of a foram-nanno chalk (Cores 7 and 8) with minor chert, radiolarian foramnanno chalk with rare chert (Cores 9 through 14) and 
TABLE 2

Smear Slide Summary, Site 313

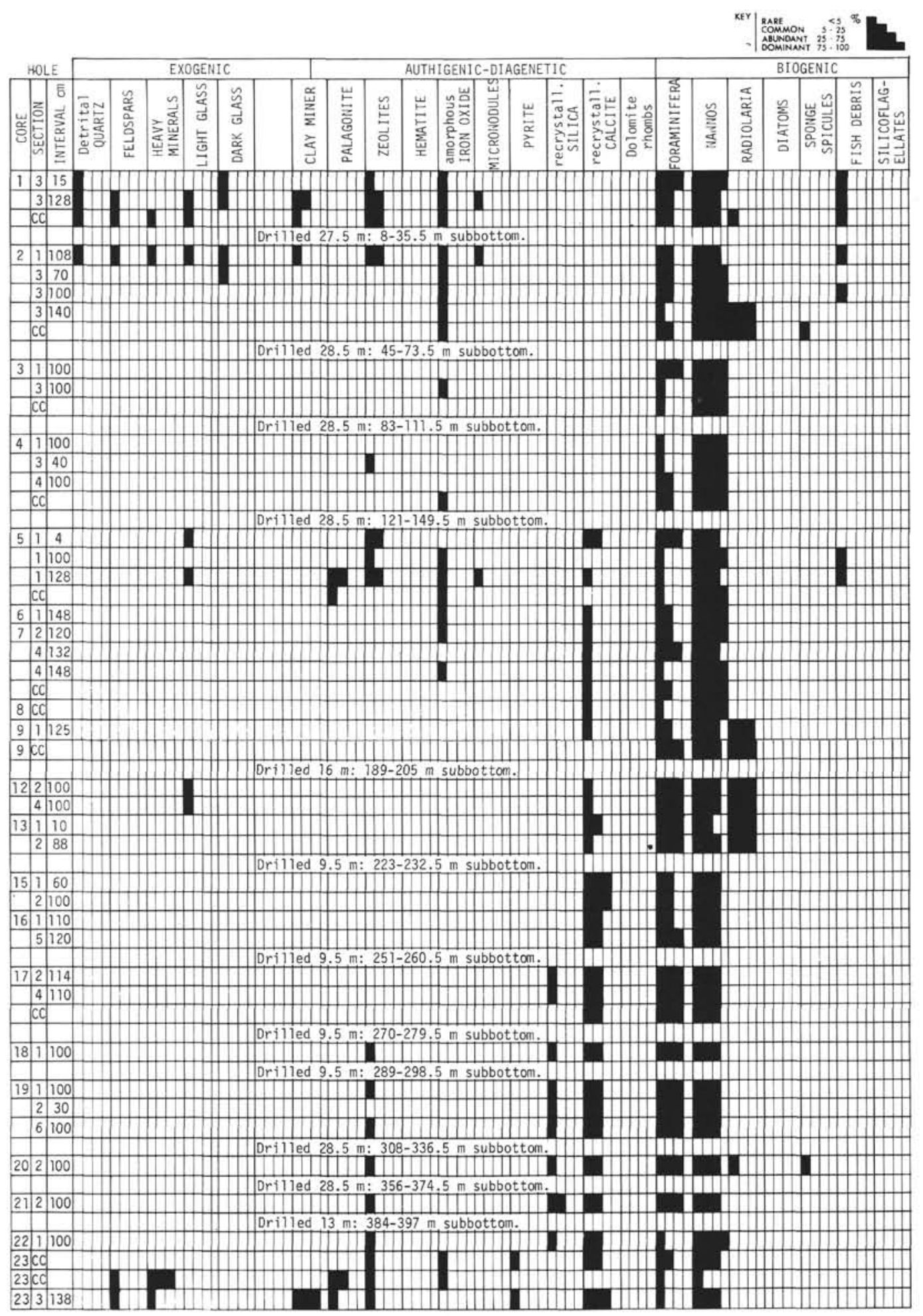




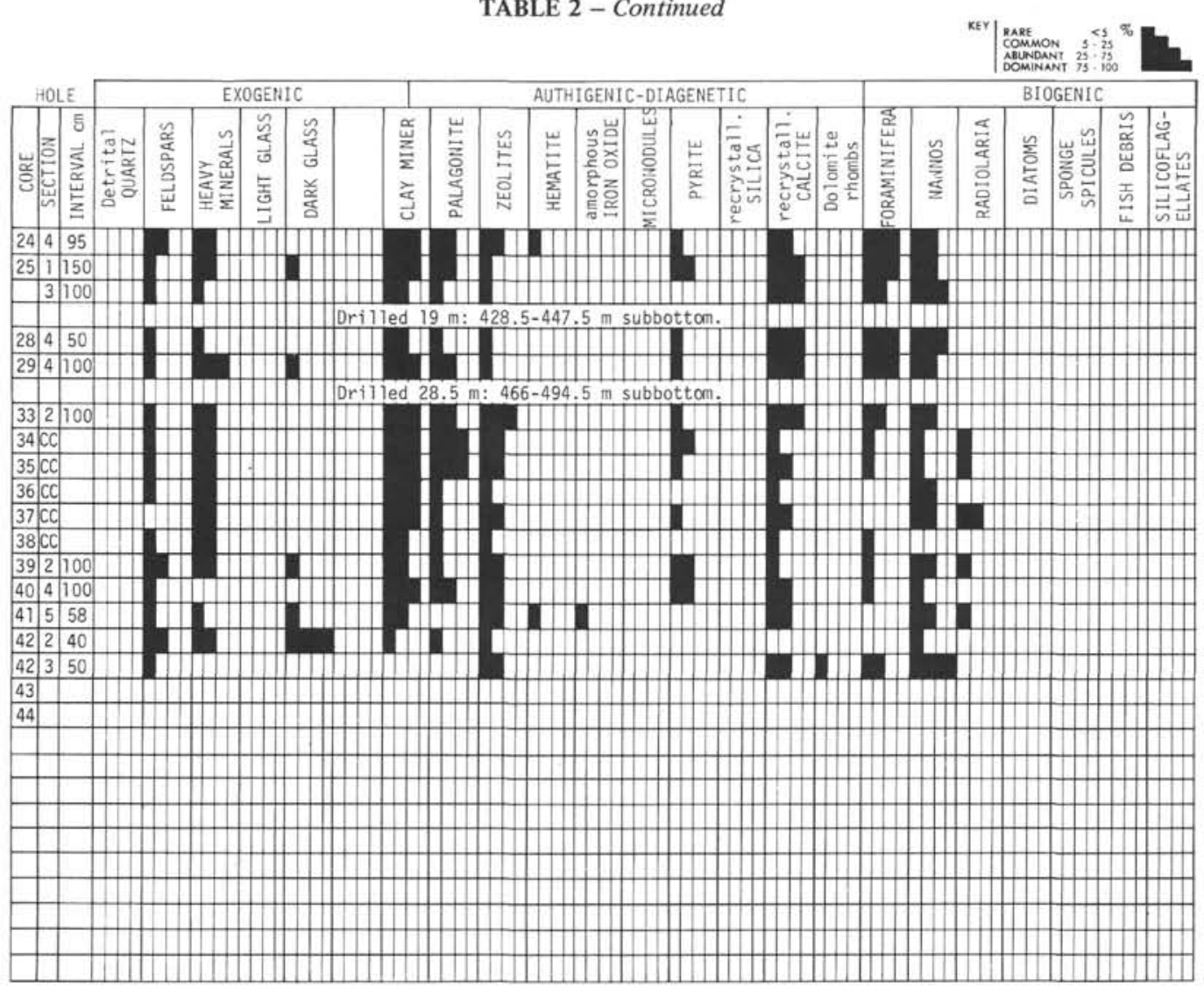

foram-nanno chalk with minor chert (Cores 15 and 16). This lower lithology continues in the discontinuously sampled interval down to the base of Unit 1 in Core 22.

The entire unit is mainly turbidite deposits with minor pelagic deposition and diagenetic chert as nodules and lenses. Due to severe drilling disturbance, it is rare to find a complete turbidite.

Radiolarians are abundant in the lower part of the Cenozoic (Cores 9 through 13) and consist of amorphous opal. In contrast, foraminifera are common throughout the unit.

Cores 17, 18, and 20 contain layers of calcareous porcellanite (recrystallized calcite and opal-CT) and the lithification has preserved microfaulting and burrowing. The faulting is probably due to slumping or compaction.

Below Core 20, Section 1, the amount of calcareous porcellanite recovered increases, and it is generally laminated with occasional burrows. The sharp contact between calcareous porcellanite and the underlying volcanic sandstone was sampled in Core 23, Section 1 .

\section{Unit 2-Volcanic Sandstone, Limestone} (Cores 23 through 42)

This unit commenced just below the hard drilling (398 $\mathrm{m})$ at 400 meters where the uppermost limestone and volcanic sandstone was encountered and continued down to the basalt of Unit 3.

The unit consists of turbidite and slump deposits of varying thickness (up to $4 \mathrm{~m}$ ) and clast size (up to 10 $\mathrm{cm}$ ). The turbidite layers consist of graded volcanic sandstone overlain by laminated volcanic siltstone, cross-bedded calcareous siltstone, laminated foramnanno limestone and bioturbated limestone. Claystone and breccia are also present. The volcanic sandstone is generally green whereas the limestone is shades of gray. All the volcanic sandstone is calcareous; however, below Core 34 the volcanic sandstone does become less calcareous and the limestone contains fewer clay minerals. The volcanic material is palagonite, angular fragments of basalt, pyroxene, and feldspar and is now cemented with zeolite, green clay (nontronite, celadonite) and minor calcite. The clastic material is poorly sorted.

Because the unit is lithified, the drilling has not dijsturbed the sedimentary structures; however, some softer layers may have been washed completely away.

A good example of sedimentary structures occurs in Core 24 , Section 3 , where thin beds $(2-4 \mathrm{~cm})$ are tightly but irregularly folded due to penecontemporaneous deformation whereas adjacent laminae in the same sample are undeformed. This type of deformation is common in the silt- and clay-sized laminae in the upper part of the turbidites throughout the unit. Burrowing, both horizontal and vertical, has partly or completely destroyed the laminations in the upper limestone part of the turbidites. Part of this burrowed limestone may represent pelagic deposition between turbidite flows. Many of the burrows contain chevron-like structures (zoophycus).

In Core 26 a breccia was sampled and shows evidence of a slump- or mudflow-type of origin. The bed is approximately 4 meters thick and consists of angular, rounded, and elongate lithic fragments (basalt, volcanic 
sandstone, claystone, limestone) varying in size up to several centimeters, with a finer-grained calcareous matrix composing more than $60 \%$ of the rock. Further evidence of massive displacement is flow lines around clasts and injection of brecciated dikes into the upper part of the bed.

The bedding planes throughout this unit are generally sharp, but are not always at right angles to the core axis. Some are inclined up to $10^{\circ}$, or even more where slumping has occurred. Bedding-plane structures are well preserved in Core 30, Section 1, and include load casts, groove casts, and ripple marks.

No chert was recovered in this unit until Core 38 , Section 1, where irregular patches and laminae $(1-2 \mathrm{~cm})$ of pale brown chert occur in nanno-limestone. Similar laminae of porcellaneous chert occurred in Core 38, Section 2, and Core 42, Section 1. Throughout the unit radiolarians are rare or absent, however, they are common above the chert in Cores 34 through 37 where they are found in the volcanic sandstone and still consist of amorphous opal.

In Core 41 , Section 3 , there is a gradational change over a few centimeters of the color of the volcanic sandstone and breccia from a dark greenish-gray to dusky yellow. This color continues for over a meter and then reverts to greenish-gray. The lithology remains the same, and the different color probably reflects the oxidation state of the iron, with the dusky yellow layer being $\mathrm{Fe}^{3+}$-rich. Below this layer the limestone also changes color to very pale orange and near the base of the unit contains dolomite rhombs $(\leq 100 \mu \mathrm{m})$. Brown volcanic glass of sand size forms black layers less than 5 $\mathrm{cm}$ thick in this limestone (Core 41, Section 5, and Core 42, Section 2).

\section{Unit 3-Fine-grained Basalt (Cores 43 and 44)}

This unit consists of fine-grained, nonporphyritic, alkali basalt. The contact between the basalt and the overlying sediments was not recovered; neither were any glassy selvages recovered. The basalt in Core 43 is moderately highly fractured (fracture spacing about 2 $\mathrm{cm})$. The fractures are filled with zeolite and calcite. The original lava evidently had a high volatile content as the basalt contains about $15 \%$ vesicles that are less than 1 $\mathrm{mm}$ diameter, as well as some larger ones up to $2 \mathrm{~cm}$ in diameter. The vesicles are filled with montmorillonite, calcite, and most commonly, zeolite. Cream-colored zeolite fills the smaller vugs, forming amygdules, and clear, drusy crystals of zeolite line the larger cavities. The basalt is generally a medium dark gray, but it has a brown color at the top and at two places in Core 43, Section 2. Much of the basalt in Core 44, Section 3 (the base of the recovered basalt) is also brownish gray. The basalt at the top of the recovered interval and the brown basalt in Core 43, Section 2, also appear to be finer grained than the rest of the basalt.

In thin section the basalt is seen to have an intersertal texture of plagioclase laths $(50 \times 400 \mu \mathrm{m})$ and brown, titanoaugite prisms $(40 \times 150 \mu \mathrm{m})$. The cores of the plagioclase laths are altered to zeolite and the groundmass is more or less altered to montmorillonite, especially in the basalt of Core 43 . The pyroxene is usually fairly fresh. The brown color is seen to be due to clouds of minute, yellow-red granules (goethite?). The grain size in the topmost basalt and the brown basalt in Core 43 , Section 2 is slightly less than in the rest of the interval. However, the fine-grained appearance of the brown basalt of Core 43, Section 2 is at least partially due to the smallness of its vesicles and because the alteration here is so extensive that the pyroxene is largely altered to clay. While not nearly as conclusive as the varioles found in the basalts of previous sites, the somewhat smaller grain size and greater degree of alteration at the two depths in Core 43, Section 2 do suggest the proximity of cooling unit margins.

\section{Conclusions}

The hole was drilled in a sediment-filled basin surrounded on the east, south, and west by volcanic highs representing part of the Mid-Pacific Mountains. The nearest guyot is less than $50 \mathrm{~km}$ away from the site.

The basal sedimentary unit represents a time of rapid deposition by turbidity currents and gravity slides from the nearby volcanic mountains. There is no evidence of shallow-water detritus so it is assumed that the source areas for the sediment remained well below sea level. The mountains provided the basaltic volcanic detritus and calcareous material for the turbidites. Intervening quiet periods allowed some pelagic carbonate deposition and burrowing to occur. Because of its smaller grain size, the carbonate that was transported by the turbidity currents forms the upper parts of most turbidites. The turbidites vary in thickness and lithology, some being more calcareous than others. Generally this reflects the flow regime of the particular turbidite at that location.

As the basin filled and the supply of volcanic detritus decreased, a more calcareous facies developed consisting of turbidite and pelagic deposition.

Lithification begins in the carbonate in Core 5 (149.5 $\mathrm{m})$ and increases down the hole. Diagenetic dolomite rhombs occur in limestone at the base of the hole.

The lack of chert in Unit 2 is probably due to the absence of siliceous microfossils and the nature of the facies. Where radiolarians do occur in this unit they still exist as opal-A.

The cement in the volcanic sandstone (Unit 2) consists of radiating sheaves of zeolite (phillipsite) and green clay (celadonite, nontronite) formed from the alteration of the volcanic glass and palagonite.

Unfortunately, no sediment-basalt contact was recovered to provide evidence as to whether the basalt of Unit 3 is extrusive or intrusive. The very fine grain size throughout the 6 meters of basalt, as well as the possibility of multiple cooling units, suggest that the basalt is extrusive. The presence of titanoaugite indicates that the basalt is alkalic, suggesting that it is neither part of the ridge-generated oceanic crust nor part of the early archipelagic apron, but instead formed somewhat late in the development of the nearby seamounts.

\section{GEOCHEMICAL MEASUREMENTS}

Alkalinity, $p \mathrm{H}$, and salinity measurements for Site 313 are summarized in Table 3 and presented graphically in Figure 4 . The sediments were squeezed at $4^{\circ} \mathrm{C}$ to obtain 
TABLE 3

Summary of Shipboard Geochemical Data

\begin{tabular}{|c|c|c|c|c|c|c|}
\hline \multirow[b]{2}{*}{$\begin{array}{c}\text { Sample } \\
\text { (Interval in } \mathrm{cm} \text { ) }\end{array}$} & \multirow[b]{2}{*}{$\begin{array}{l}\text { Depth Below } \\
\text { Sea Floor }(\mathrm{m})\end{array}$} & \multicolumn{2}{|c|}{$p \mathrm{H}$} & \multirow[b]{2}{*}{$\begin{array}{l}\text { Alkalinity } \\
(\mathrm{meq} / \mathrm{kg})\end{array}$} & \multirow[b]{2}{*}{$\begin{array}{c}\text { Salinity } \\
(\% \circ)\end{array}$} & \multirow{2}{*}{$\begin{array}{c}\text { Remarks } \\
\text { (Combination } \\
\text { Electrode } p \mathrm{H})\end{array}$} \\
\hline & & $\begin{array}{l}\text { Punch- } \\
\text { in }\end{array}$ & $\begin{array}{l}\text { Flow- } \\
\text { through }\end{array}$ & & & \\
\hline Surface Seawater & & 8.20 & 8.28 & 2.33 & 35.5 & 8.32 \\
\hline $1-5,144-150$ & 7.5 & 7.66 & 7.57 & 2.58 & 35.0 & 7.73 \\
\hline $2-2,144-150$ & 38.5 & 7.52 & 7.57 & 2.47 & 35.8 & 7.61 \\
\hline $3-2,144-150$ & 76.5 & 7.66 & 7.52 & 2.59 & 35.5 & 7.70 \\
\hline $4-1,144-150$ & 113.0 & 7.60 & 7.57 & 2.60 & 35.5 & 7.66 \\
\hline $5-6,144-150$ & 158.5 & 7.69 & 7.55 & 2.76 & 35.5 & 7.66 \\
\hline $7-6,144-150$ & 177.0 & 7.67 & 7.56 & 2.78 & 35.5 & 7.65 \\
\hline $12-4,144-150$ & 211.0 & 7.66 & 7.50 & 2.71 & 35.8 & 7.61 \\
\hline $17-4,144-150$ & 266.5 & - & 7.47 & 2.50 & 35.5 & 7.54 \\
\hline $20-2,144-150$ & 339.5 & 7.57 & 7.43 & 1.51 & 35.4 & 7.51 \\
\hline $24-4,0-6$ & 415.5 & - & 8.48 & 0.23 & 34.4 & - \\
\hline $29-3,144-150$ & 461.5 & - & 8.20 & 0.23 & 34.1 & - \\
\hline $35-3,144-150$ & 518.0 & - & 8.34 & 0.29 & 34.4 & - \\
\hline
\end{tabular}
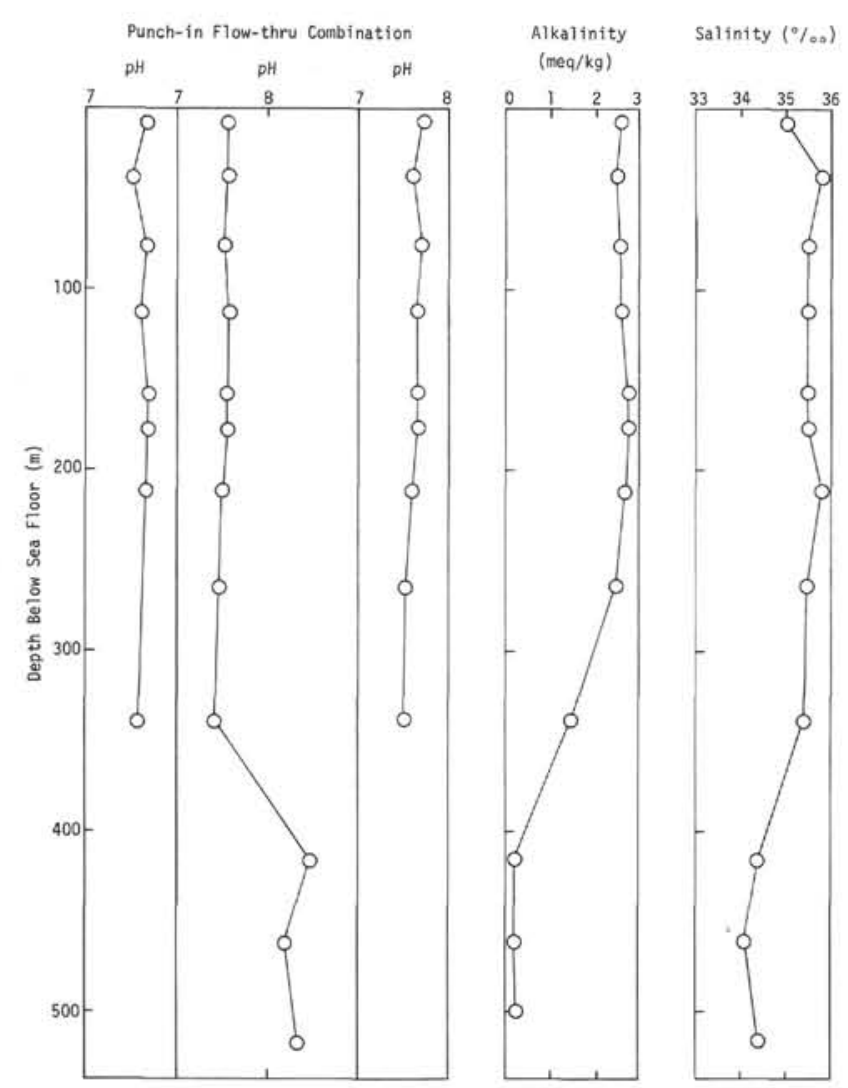

Figure 4. Graphic summary of geochemical data taken at Site 313.

the interstitial water. Twelve interstitial water samples down to 518 meters (depth subbottom) were collected. Below this depth the sediment was too lithified for squeezing.

\footnotetext{
Alkalinity

Alkalinity gradually increases with depth to a maximum measured value of $2.78 \mathrm{meq} / \mathrm{kg}$ at 177 meters and then decreases to $1.51 \mathrm{meq} / \mathrm{kg}$ at 339.5 meters. These values are in carbonate ooze and chalk. Below 339.5 meters samples were taken from a volcanic turbidite se-
}

quence and the alkalinity values are extremely low $(<0.3$ $\mathrm{meq} / \mathrm{kg}$ ).

\section{$\mathrm{pH}$}

The $p \mathrm{H}$ of the interstitial water is less than seawater for all samples in the carbonate section (Unit 1, 0-400 $\mathrm{m}$ ). Within the volcanic turbidite section (Unit 2, 400$518 \mathrm{~m}$ ) the $p \mathrm{H}$ varies from 8.20 to 8.48 .

\section{Salinity}

The salinity of the interstitial water ranges from $34.1 \%$ near the base of the hole to $35.8 \%$ in the upper carbonate section. The surface seawater salinity is $35.5 \%$.

\section{PHYSICAL PROPERTIES}

\section{Wet Bulk Density and Porosity of Soft Sediments}

The wet bulk density of the soft, moderately intensely disturbed calcareous oozes and semilithified chalks was measured with the GRAPE. In general, Sections 2 and 5 of cores were measured. The density increases from 1.5 $\mathrm{g} / \mathrm{cc}$ in the surface ooze to $1.8 \mathrm{~g} / \mathrm{cc}$ in the chalk at 150 meters (Core 5). The density then decreases with depth to $1.6 \mathrm{~g} / \mathrm{cc}$ in the chalk at 220 meters (Core 13), whereupon it resumes its increase with depth, reaching a density of about $1.9 \mathrm{~g} / \mathrm{cc}$ in the chalk at 270 meters (Core 17). The syringe data from the calcareous ooze show that the wet bulk density increase with depth is due to a decrease in porosity from $70 \%$ at the surface to about $55 \%$ at 120 meters (Core 4). The syringe data from the chalks are limited to Core 5. Some of the wet bulk density variation with depth in the chalks may be due to mineralogic changes, such as varying amounts of siliceous components, but most of the variation is probably due to porosity changes. Therefore, the porosity of the chalks increases from $55 \%$ in Core 5 to $65 \%$ in Core 13 and then decreases to about $45 \%$ in Core 17.

\section{Sonic Velocity}

The sonic velocity, $V p$, of the calcareous sediment and rocks increases with lithification. The $V p$ of the calcareous ooze is $1.5 \mathrm{~km} / \mathrm{sec}$, that of the chalk is 1.7 
$\mathrm{km} / \mathrm{sec}$, and the $V p$ of the limestone ranges from 1.8 to $3.9 \mathrm{~km} / \mathrm{sec}$ (the average $V p$ is $2.6 \mathrm{~km} / \mathrm{sec}$ ). The sonic velocity of the volcanic sandstones ranges from 2.0 to $3.2 \mathrm{~km} / \mathrm{sec}$ (the average $V p$ is $2.6 \mathrm{~km} / \mathrm{sec}$ ). The porcellanite in Core 21 has a $V p$ of $2.7 \mathrm{~km} / \mathrm{sec}$, whereas the $V p$ of the chert in Core 10 is, characteristically, 5.0 $\mathrm{km} / \mathrm{sec}$. The velocity of the basalt increases from 3.7 $\mathrm{km} / \mathrm{sec}$ in the altered top to $5.2 \mathrm{~km} / \mathrm{sec}$ in the dense, relatively unaltered interior, and then decreases to 4.6 $\mathrm{km} / \mathrm{sec}$ in the altered, basal portion. Although the $V p$ of both the limestone and volcanic sandstone varies widely, the data suggest a general increase in $V p$ with depth. The average $V p$ is $1.5 \mathrm{~km} / \mathrm{sec}$ at the surface, 1.6 $\mathrm{km} / \mathrm{sec}$ at 150 meters, $2.0 \mathrm{~km} / \mathrm{sec}$ at 300 meters, 2.5 $\mathrm{km} / \mathrm{sec}$ at 450 meters, and $3.0 \mathrm{~km} / \mathrm{sec}$ at 590 meters.

\section{CORRELATION OF SEISMIC PROFILES WITH DRILLING RESULTS}

The seismic reflection profile recorded while approaching the site (Figure 3 ) shows essentially two subbottom reflectors at about 0.22 and $0.40 \mathrm{sec}$. The latter was believed to be the regional acoustic basement until a lower reflection was observed at about $0.55 \mathrm{sec}$ while on our final approach to the site at a slow speed. The presence of this reflector was confirmed later, when a sonobuoy record was obtained while on site. It probably represents the regional acoustic basement.

The first subbottom reflector, at $0.22 \mathrm{sec}$, is believed to correlate with a hard layer recorded by the driller at 188 meters. No definite change can be observed at this level in the lithology of the sediments, although the chalk appears to be consistently more lithified from Core 9 (186.5-189 m) down. This correlation gives an interval velocity of $1.7 \mathrm{~km} / \mathrm{sec}$ for the uppermost interval of the section. This velocity seems reasonable as the sediment is dominantly calcareous ooze with some chert and chalk in the lower 40 meters of the interval.

The correlation between the second reflector, at 0.40 sec, and the lithology is rather well established and supported by both a lithological change (top of the limestone sequence) and the presence of very hard layers recorded by the driller at 398 meters. The interval velocity computed for the chalk and chert interval lying between 188 meters and 398 meters is therefore $2.3 \mathrm{~km} / \mathrm{sec}$.

Basalt was reached at 594 meters and it certainly corresponds with the lowermost reflector. The interval velocity obtained for the sequence of limestones and well-lithified volcanic detritus found above the basement reaches $2.6 \mathrm{~km} / \mathrm{sec}$. All the computed interval velocities show a generally good agreement with the velocities measured directly on the sediments.

Figure 5 summarizes these correlations.

\section{BIOSTRATIGRAPHIC SUMMARY}

Coccoliths and foraminifers are present through most of the Cenozoic section of Cores 1 to $14(0-233 \mathrm{~m})$. Radiolaria are present in Quaternary Core 1, Miocene Core 2, and early Eocene Cores 9, 12, and 13, but are missing in middle Eocene to Oligocene Cores 3 to 8 . Continuous coring of the Cenozoic was done in the Paleocene to Eocene section from Cores 5 to 14 (150-233 m). Warm-water zonal assemblages are indicated throughout by the abundant occurrence of discoasters.
Reworked older fossils are prominent in the Quaternary, middle Miocene, and middle to late Eocene.

Coccoliths are abundant with moderate to poor preservation throughout the Mesozoic section (Maestrichtian-Campanian) Cores 51 to 42 . Foraminifera are diversified and well preserved in Cores 15 through 19 (Maestrichtian), but fewer and less well preserved in Cores 20 through 42. In contrast, Radiolaria are almost entirely lacking in Cores 15 through 19 and 33 through 36 and generally few to rare with poor to moderate preservation in the remaining cores.

On the basis of the coccoliths, Cores 20 to 40 are assigned to the late Campanian and early Maestrichtian Tetralithus trifidus Zone and Cores 41 and 42 to the subjacent Campanian Broinsonia parca Zone. According to the foraminifera, the presence of Globotruncana calcarata in Core 24 indicates the top of the Campanian.

The nominal age of the oldest sediment above basalt is late Campanian (76 \pm 5 m.y.).

\section{Foraminifera}

\section{Cenozoic}

Core 1 contains a mixed assemblage of Quaternary to late Miocene planktonic foraminifera which are partially dissolved. Middle Miocene assemblages with reworked early Eocene and Campanian to Maestrichtian planktonic foraminifera are found in Core 2.

The core-catcher samples of Cores 3 and 5 contain a nondiverse late Oligocene fauna. Core 3 is assigned to Zone P21 and Core 4 to Zones P20-P19.

Cores 5 to 7 are attributed to the upper part of the middle Eocene. The microfaunas are rather poor and badly preserved and are therefore not attributed to a definite zone. A sample from the core catcher of Core 8 is barren.

The two samples examined from Core 9 are dominated by Radiolaria. The few planktonic foraminifera are poorly preserved, but indicate nevertheless the Globorotalia aragonensis Zone (upper part of early Eocene).

No washed residues could be obtained from Cores 10 and 11 .

Cores 12 and 13 are placed into the early Eocene Globorotalia subbotinae Zone. Almost all washed residues are very rich in Radiolaria.

A thin section made from the chert recovered in Core 14 contains no forms suitable for an age determination.

\section{Mesozoic}

Rich and well-preserved microfaunas of Maestrichtian age are found in Cores 15 to 19. Starting with Core 20 , the number of planktonic foraminifera decreases and their preservation becomes rather poor. Most of the few Globotruncana found in Cores 22 and 23 are indeterminate.

The presence of Globotruncana calcarata in Core 24 allows one to recognize the top of the Campanian. Representatives of this species, which indicates the uppermost zone of the Campanian, are found down to Core 31.

The number and preservation of the foraminifera in Cores 25 to 42 are very variable. Commonly, the few 


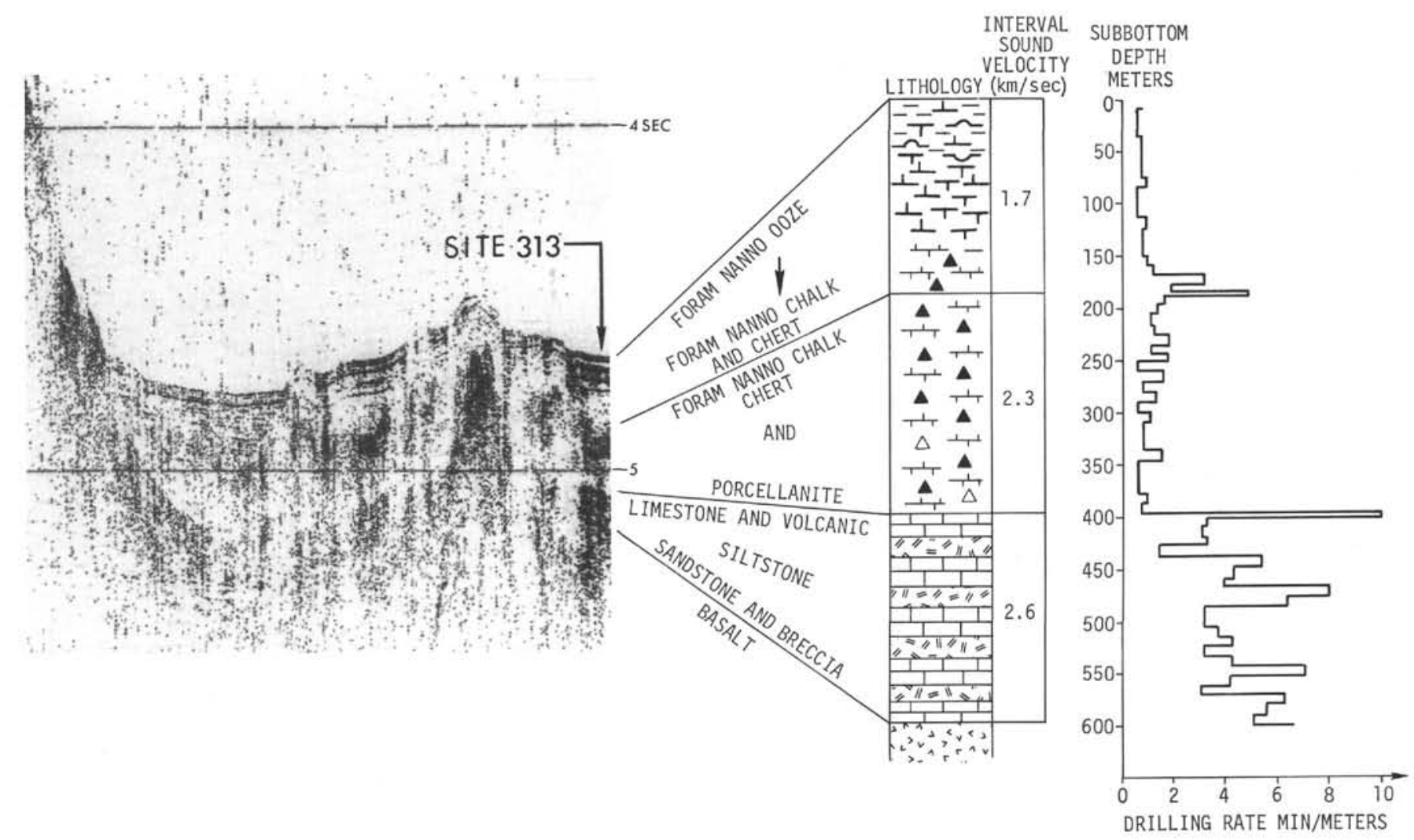

Figure 5. Correlation of seismic reflection profile with drilling results at Site 313.

specimens encountered are heavily encrusted and indeterminate, but a few intercalations contain sufficiently well-preserved specimens which allow one to attribute the entire interval to the Campanian. Starting with Core 40 , the number of benthonic foraminifera and ostracodes increases.

\section{Coccoliths}

\section{Cenozoic}

Coccolith assemblages ranging from Quaternary in Sample 1, CC $(8 \mathrm{~m})$ to late Paleocene Discoaster multiradiatus Zone in Sample 14, CC $(233 \mathrm{~m})$ occur in the Cenozoic section at Site 313. Coccoliths are abundant throughout but preservation is moderate to poor. Warm-water zonal assemblages with abundant discoasters are present throughout. Reworked specimens are common in Cores 1, 5, and 8. Core-catcher samples of Cores 5 to 13 (159-223 m) contain a range of Eocene zones that suggests a relatively complete Eocene section is present at Site 313 . The Paleocene is represented only by a thin chalk bed in Core 14. The next deeper sample at the top of Core 15 is late Cretaceous.

\section{Mesozoic}

Coccoliths are generally abundant and have moderate to poor preservation in the Campanian to Maestrichtian section (Cores 15 to $42,233-588 \mathrm{~m}$ ) recovered above basalt (Cores 43 to $44,588-606 \mathrm{~m}$ ). Most of the Mesozoic section, Cores 20 to 40 , is assigned to the late Campanian to early Maestrichtian Tetralithus trifidus Zone. Coccolith assemblages of Cores 41 and 42 (569-
$588 \mathrm{~m}$ ) are assigned to the subjacent Campanian Broinsonia parca Zone based on the presence of Broinsonia parca and the absence of Eiffellithus eximius and Tetralithus trifidus. Therefore the nominal age of the oldest sediment above basalt is late Campanian ( $76 \pm 5$ m.y.)

\section{Radiolaria}

\section{Cenozoic}

Radiolaria are present only in Cores $1,2,9,12$, and 13 of the Cenozoic section. They are well preserved and common in all of these cores except Core 1, where they are rare.

Core $1(0-8 \mathrm{~m})$ contains a mixed Quaternary-Pliocene assemblage. Radiolaria in Core $2(35-45 \mathrm{~m})$ are of late early Miocene age, Calocycletta costata Zone. In Core 9 they belong to the upper part of the Buryella clinata Zone, and are considered to be late early Eocene. Cores 12 and 13 (205-223 m) contain Radiolaria belonging to the Bekoma bidarfensis Zone, both early Eocene (P6).

Fish teeth were looked for in Cores 1 and 3 through 7. They were present in moderate quantities in all the cores except 6 .

\section{Mesozoic}

Radiolaria are not present in Cores 15 to 19 , except for some very poor and very rare specimens in Core 15 . They are missing also in Cores 24,33 through 36 , and Sample 40-2, 99-101 cm. They are rare to few in Cores 20 through 23, 25 through 27,30 through 32 , and 37 through 42. 
The poorly preserved Radiolaria of Cores 20 through $23(336-409 \mathrm{~m})$ and 30 through $32(466-494 \mathrm{~m})$ are attributed to the late Late Cretaceous and the moderate to good Radiolaria of Cores 25 through $27(419-447 \mathrm{~m})$ and 37 through $41(532-578 \mathrm{~m})$ to the Campanian. The poor Radiolaria of Core $42(578-588 \mathrm{~m})$ are considered to be Late Cretaceous.

A biostratigraphic summary for Site 313 appears in Table 4.

Cores $26,38,39$, and 41 may be assigned to the Amphipyndax enesseffi Zone.

\section{SEDIMENTATION RATES}

The average accumulation rates for Site 313 can be separated into four general categories which correspond to different lithologic types; nanno oozes and rad nanno oozes, foram nanno oozes and foram nanno chalks with cherts and porcellanites, limestones, and interbedded limestones and turbidites, with accumulation rates of 3 $\mathrm{m} / \mathrm{m} . \mathrm{y}$., $8 \mathrm{~m} / \mathrm{m} . \mathrm{y}$., $25 \mathrm{~m} / \mathrm{m} . \mathrm{y}$, and greater than 25 $\mathrm{m} / \mathrm{m} . y_{\text {., }}$ respectively (Table 5 and Figure 6). The accumulation rate values for the oozes are reasonable

TABLE 4

Distribution, Age, and Frequency of Investigated Microfossils

\begin{tabular}{|c|c|c|c|c|c|c|c|c|c|}
\hline \multirow[b]{2}{*}{ 3ั } & \multirow[b]{2}{*}{ Depth $(m)$} & \multirow{2}{*}{ 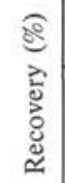 } & \multicolumn{3}{|c|}{ Foraminifera } & \multirow{2}{*}{\multicolumn{2}{|c|}{$\begin{array}{c}\text { Calcareous } \\
\text { Nannoplankton }\end{array}$}} & \multirow{2}{*}{\multicolumn{2}{|c|}{ Radiolaria }} \\
\hline & & & $\frac{\text { लี }}{2}$ & Е & & & & & \\
\hline 1 & $0.0-8.0$ & 100 & $*$ & + & $\begin{array}{l}\text { Quaternary/ } \\
\text { late Miocene }\end{array}$ & $\bullet$ & $\begin{array}{l}\text { Top: Quater.-L. Plioc. } \\
\text { Base: Late Miocene }\end{array}$ & + & $\begin{array}{l}\text { mixed Pleistocene } \\
\& \text { Pliocene }\end{array}$ \\
\hline 2 & $35.5-45.0$ & 37 & $*$ & + & Middle Miocene & $\bullet$ & Middle Miocene & o & $\begin{array}{l}\text { Late early } \\
\text { Miocene }\end{array}$ \\
\hline 3 & $73.5-83.0$ & 93 & + & + & Late Oligocene & $\bullet$ & Late Oligocene & - & - \\
\hline 4 & $111.5-121.0$ & 94 & $*$ & + & $\begin{array}{l}\text { Early (?) } \\
\text { Oligocene }\end{array}$ & $\bullet$ & Early Oligocene & - & - \\
\hline 5 & $149.5-159.0$ & 100 & o & * & Middle Eocene & • & $\begin{array}{l}\text { Late/middle } \\
\text { Eocene }\end{array}$ & * & - \\
\hline 6 & $159.0-168.0$ & 3 & o & + & Middle Eocene & $\bullet$ & Middle Eocene & - & - \\
\hline 7 & $168.0-177.0$ & 90 & $\bullet$ & + & Middle Eocene & $\bullet$ & Middle Eocene & + & - \\
\hline 8 & $177.0-186.5$ & 1 & - & - & - & $\bullet$ & Middle Eocene & - & - \\
\hline 9 & $186.5-189.0$ & 36 & + & - & Early Eocene & $\bullet$ & Early Eocene & $\bullet$ & $\begin{array}{l}\text { Late early } \\
\text { Eocene }\end{array}$ \\
\hline 10 & $189.0-195.5$ & 1 & - & - & - & - & - & - & - \\
\hline 11 & $195.5-205.0$ & 1 & - & - & - & - & - & - & - \\
\hline 12 & $205.0-214.0$ & 72 & o & + & Early Eocene & $\bullet$ & Early Eocene & • & Early Eocene \\
\hline 13 & $214.0-223.0$ & 105 & o & + & Early Eocene & $\bullet$ & Early Eocene & $\bullet$ & Early Eocene \\
\hline 14 & $223.0-242.0$ & 1 & + & - & - & $\bullet$ & Early Eocene & - & - \\
\hline 15 & $232.5-242.0$ & 58 & $\bullet$ & 0 & $\begin{array}{l}\text { Middle } \\
\text { Maestrichtian }\end{array}$ & $\bullet$ & $\begin{array}{l}\text { Early } \\
\text { Maestrichtian }\end{array}$ & + & - \\
\hline 16 & $242.0-251.0$ & 78 & - & * & $\begin{array}{l}\text { Middle } \\
\text { Maestrichtian }\end{array}$ & $\bullet$ & $\begin{array}{l}\text { Early } \\
\text { Maestrichtian }\end{array}$ & - & - \\
\hline 17 & $260.5-270.0$ & 68 & $\bullet$ & $*$ & $\begin{array}{l}\text { Middle } \\
\text { Maestrichtian }\end{array}$ & $\bullet$ & $\begin{array}{l}\text { Early } \\
\text { Maestrichtian }\end{array}$ & - & - \\
\hline 18 & $279.5-289.0$ & 79 & $\bullet$ & + & $\begin{array}{l}\text { Early } \\
\text { Maestrichtian }\end{array}$ & $\bullet$ & $\begin{array}{l}\text { Early } \\
\text { Maestrichtian }\end{array}$ & - & - \\
\hline 19 & $298.5-308.0$ & 100 & $\bullet$ & o & $\begin{array}{l}\text { Early } \\
\text { Maestrichtian }\end{array}$ & $\bullet$ & $\begin{array}{l}\text { Early } \\
\text { Maestrichtian }\end{array}$ & - & - \\
\hline 20 & $336.5-346.0$ & 41 & - & * & $\begin{array}{l}\text { Early } \\
\text { Maestrichtian }\end{array}$ & $\bullet$ & $\begin{array}{l}\text { Early Maestrich. } \\
\text { or late Campan. }\end{array}$ & + & $\begin{array}{l}\text { late late } \\
\text { Cretaceous }\end{array}$ \\
\hline 21 & $374.5-384.0$ & 79 & o & + & $\begin{array}{l}\text { Early } \\
\text { Maestrichtian }\end{array}$ & $\bullet$ & $\begin{array}{l}\text { Early Maestrich. } \\
\text { or late Campan. }\end{array}$ & + & $\begin{array}{l}\text { late Late } \\
\text { Cretaceous }\end{array}$ \\
\hline 22 & $397.0-400.0$ & 100 & + & + & $\begin{array}{l}\text { Early } \\
\text { Maestrichtian }\end{array}$ & * & $\begin{array}{l}\text { Early Maestrich. } \\
\text { or late Campan. }\end{array}$ & + & $\begin{array}{l}\text { late Late } \\
\text { Cretaceous }\end{array}$ \\
\hline 23 & $400.0-409.5$ & 5 & $*$ & + & $\begin{array}{l}\text { Early } \\
\text { Maestrichtian }\end{array}$ & 0 & $\begin{array}{l}\text { Early Maestrich. } \\
\text { or late Campan. }\end{array}$ & + & $\begin{array}{l}\text { late Late } \\
\text { Cretaceous }\end{array}$ \\
\hline 24 & $409.5-419.0$ & 80 & $\bullet$ & + & Late Campanian & o & $\begin{array}{l}\text { Early Maestrich. } \\
\text { or late Campan. }\end{array}$ & - & - \\
\hline 25 & $419.0-428.5$ & 54 & $*$ & + & Late Campanian & $\bullet$ & $\begin{array}{l}\text { Early Maestrich. } \\
\text { or late Campan. }\end{array}$ & + & Campanian \\
\hline 26 & $428.5-438.0$ & 20 & + & + & Late Campanian & o & $\begin{array}{l}\text { Early Maestrich. } \\
\text { or late Campan. }\end{array}$ & + & Campanian \\
\hline
\end{tabular}


TABLE 4 - Continued

\begin{tabular}{|c|c|c|c|c|c|c|c|c|c|}
\hline \multirow[b]{2}{*}{ ¿ัర } & \multirow[b]{2}{*}{ Depth (m) } & \multirow{2}{*}{ 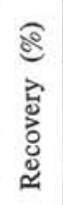 } & \multicolumn{3}{|c|}{ Foraminifera } & \multirow{2}{*}{\multicolumn{2}{|c|}{$\begin{array}{c}\text { Calcareous } \\
\text { Nannoplankton }\end{array}$}} & \multirow{2}{*}{\multicolumn{2}{|c|}{ Radiolaria }} \\
\hline & & & 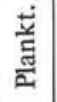 & 豆 & & & & & \\
\hline 27 & $438.0-447.5$ & 33 & $*$ & + & Late Campanian & 0 & $\begin{array}{l}\text { Early Maestrich. } \\
\text { or late Campan. }\end{array}$ & + & Campanian \\
\hline 28 & $447.5-457.0$ & 53 & o & + & Late Campanian & - & - & - & - \\
\hline 29 & $457.0-466.0$ & 58 & o & + & Late Campanian & - & - & - & - \\
\hline 30 & $466.0-475.5$ & 46 & $*$ & + & Early Campanian & $\bullet$ & $\begin{array}{l}\text { Early Maestrich. } \\
\text { or late Campan. }\end{array}$ & + & - \\
\hline 31 & $475.5-485.0$ & 69 & o & + & Early Campanian & - & - & + & - \\
\hline 32 & $485.0-494.5$ & 43 & o & + & Early Campanian & o & $\begin{array}{l}\text { Early Maestrich. } \\
\text { or late Campan. }\end{array}$ & + & - \\
\hline 33 & $494.5-504.0$ & 29 & $*$ & + & Early Campanian & $*$ & $\begin{array}{l}\text { Early Maestrich. } \\
\text { or late Campan. }\end{array}$ & - & - \\
\hline 34 & $504.0-513.5$ & 49 & + & + & Early Campanian & $*$ & $\begin{array}{l}\text { Early Maestrich. } \\
\text { or late Campan. }\end{array}$ & - & - \\
\hline 35 & $513.5-523.0$ & 76 & + & + & Early Campanian & + & $\begin{array}{l}\text { Early Maestrich. } \\
\text { or late Campan. }\end{array}$ & - & - \\
\hline 36 & $523.0-532.5$ & 64 & * & + & Early Campanian & + & $\begin{array}{l}\text { Early Maestrich. } \\
\text { or late Campan. }\end{array}$ & - & - \\
\hline 37 & $532.5-542.0$ & 100 & + & + & $\begin{array}{l}\text { Early } \\
\text { Campanian (?) }\end{array}$ & o & $\begin{array}{l}\text { Early Maestrich. } \\
\text { or late Campan. }\end{array}$ & + & Campanian \\
\hline 38 & $542.0-551.0$ & 50 & + & + & $\begin{array}{l}\text { Early } \\
\text { Campanian (?) }\end{array}$ & o & $\begin{array}{l}\text { Early Maestrich. } \\
\text { or late Campan. }\end{array}$ & + & Campanian \\
\hline 39 & $551.0-560.0$ & 58 & + & + & $\begin{array}{l}\text { Early } \\
\text { Campanian (?) }\end{array}$ & o & $\begin{array}{l}\text { Early Maestrich. } \\
\text { or late Campan. }\end{array}$ & + & Campanian \\
\hline 40 & $560.0-569.0$ & 50 & + & + & - & o & $\begin{array}{l}\text { Early Maestrich. } \\
\text { or late Campan. }\end{array}$ & - & - \\
\hline 41 & $569.0-578.5$ & 69 & + & + & - & $\bullet$ & Late Campanian & + & Campanian \\
\hline 42 & $578.5-588.0$ & 47 & + & $*$ & - & $\bullet$ & Late Campanian & + & Late Cretaceous \\
\hline 43 & $588.0-597.0$ & 21 & BAS & $\prod_{\mathrm{ALT}}$ & & & & & \\
\hline 44 & $597.0-606.0$ & 51 & & & & & & & \\
\hline
\end{tabular}

Note: • abundant; o common; * frequent; + rare; - absent.

TABLE 5

Correlation of Accumulation Rates with Age and Lithology

\begin{tabular}{lcl}
\hline \multicolumn{1}{c}{ Age } & $\begin{array}{c}\text { Accumulation } \\
\text { Rate }(\mathrm{m} / \mathrm{m} . \mathrm{y} .)\end{array}$ & \multicolumn{1}{c}{$\begin{array}{c}\text { Generalized } \\
\text { Lithology }\end{array}$} \\
\hline Late Oligocene to Quaternary & 3 & Nanno ooze and rad nanno ooze \\
Early Oligocene to late Oligocene & 8 & Foram nanno ooze \\
Middle Eocene to early Oligocene & 5 & $\begin{array}{l}\text { Nanno chalk } \\
\text { Late Paleocene to middle Eocene }\end{array}$ \\
Cretaceous (Maestrichtian) & 8 & $\begin{array}{l}\text { Foram nanno chalk with chert } \\
\text { and procellanites }\end{array}$ \\
Cretaceous (Campanian) & 25 & $\begin{array}{l}\text { Limestone } \\
\text { Interbedded limestones and } \\
\text { turbidites }\end{array}$ \\
\hline
\end{tabular}

values for the corresponding sediment type when compaction is taken into account. The accumulation rate for the interbedded limestones and turbidites is a minimum because of the lack of biostratigraphic zones within the section.

\section{SUMMARY AND CONCLUSIONS}

The principal lithologic characteristic of this site is the dominance of carbonate deposition from within the Cretaceous to the present day. The prevalence of calcare- 


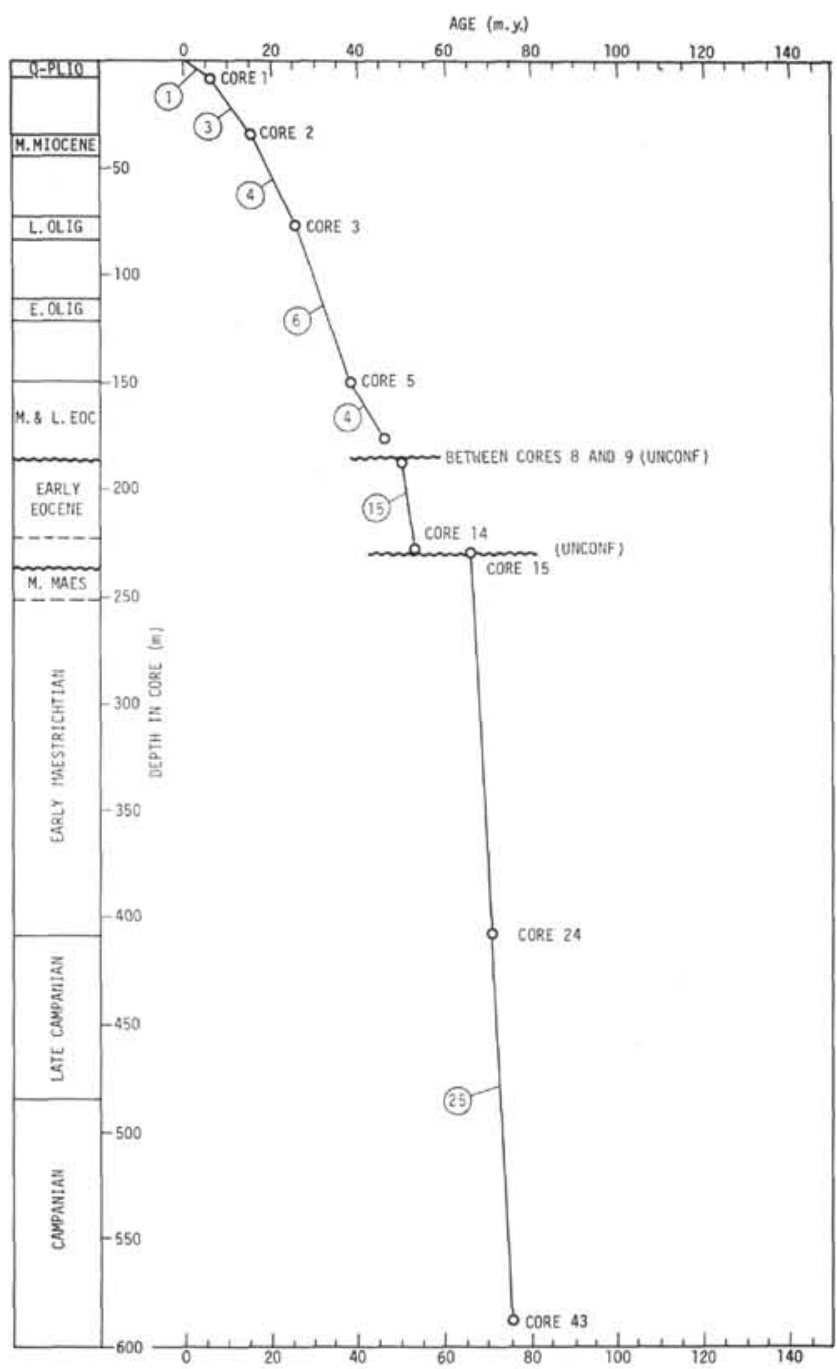

Figure 6. Accumulation rate curve calculated for Site 313. Circled numbers give accumulation rate in $\mathrm{m} / \mathrm{m} . \mathrm{y}$. for each segment.

ous sediment is due largely to the situation of the site as a topographic basin at 3500 meters. The depth is not so great that all the carbonate has dissolved, even though many of the faunas and floras are not well preserved. The topography has directed carbonate, in the form of turbidite deposits from the flanks of the adjacent seamounts, into the basin, and that reworked carbonate is added to the pelagic contribution.

It is the other components added to the carbonate which allow details of the geologic history of the site to be worked out and the microfossils which allow the evenis to be dated. The earliest sedimentary event that can be identified, just after extrusion of the basalts that are discussed in the next paragraph, is the admixture of volcanic-rich turbidites with carbonates in the form of foraminiferal-nannofossil limestones. The volcanic grains of silt, sand, and pebble size, show in thin section to have been mainly palagonitized glass, now largely altered to clay so that these rocks can be cut readily with the band saw. Presumably the clay matrix of some of these rocks is also of volcanic origin. Typical graded sequences have basal breccias that pass upwards into calcareous volcanic sandstones and calcareous siltstones or limestones. A great variety of sedimentary structures and rock types is present and will provide material for the study of microfacies well beyond the attention afforded them by the shipboard party (Moberly and Keene, this volume).

These Coniacian turbidites date a volcanic episode of the adjacent seamounts of the Mid-Pacific Mountains. It will be recalled that at Horizon Guyot (Site 171) there was a period of volcanic activity in the Coniacian and Turonian. Those volcanic sediments rest on a lava flow which in turn is on a shallow-water conglomerate, a hyaloclastite breccia, and a thick section of shallowwater friable coquina, probably Cenomanian at the top but mainly undated, lying on another basalt presumed to be the volcanic edifice of the guyot 145 meters below the Turonian lava. Albian planktonic foraminifera had been picked from cracks in basalt dredged elsewhere on Horizon Guyot, and mid-Cretaceous shallow-water rudistid and coral faunas had been dredged from many of the guyots farther west in the Mid-Pacific Mountains. Perhaps an analogous situation of recurrent volcanism exists at Site 313. The basalt of the deepest core does indeed correlate with acoustic basement, but the last 3 meters of core was cut exceptionally fast and probably was not recovered. Perhaps it was sediment, and if so, here as at Horizon Guyot a section of older sediment may exist between the main volcanic rocks of the MidPacific Mountains Ridge and Coniacian recurrent volcanism. The alkalic tendency of the lava would support that possibility.

In either event, whether the Coniacian volcanism is the only episode, or whether it is a recurrent episode, there are problems in interpreting the behavior of volcanic chains. In the former instance it would mean that volcanism did not proceed in one direction along the ridge, because 30 m.y. older volcanoes are known both west and east of it. In the second instance, the recurrence of volcanism after as long as $30 \mathrm{~m} . \mathrm{y}$. is not typical of other island or seamount chains. However, the Mid-Pacific Mountains certainly are not a typical seamount chain. Their strike is not parallel to the other chains, and thereby does not fit easily into the "hot spot" or other concepts of the origin of volcanic chains popular at this date. Also, this group of seamounts is generally wider than other chains, has more guyots, and has no geomorphic suggestion of differences in ages along them.

No good evidence of shallow-water contributions to the sedimentary record is known, except for an increase in pollen, benthonic foraminifers, and ostracodes that may suggest somewhat lesser depths in the lowest sediment cores.

In the Maestrichtian and continuing through the middle Eocene, silica was the principal addition to the dominantly carbonate sediment. In the early Eocene rocks much of the silica remains as radiolarians, but there, as well as above and below, is silica in the form of modest amounts of chert and porcellanite. The early Eocene radiolarian faunas are worthy of intensive study (Foreman, this volume). 
In the post-Eocene section only four cores were obtained. The Oligocene carbonates are quite pure foraminiferal nannofossil oozes, but the Miocene and Quaternary oozes have modest additions of radiolarians and of zeolites, respectively. Turbidite bedding and reworked foraminifers indicate that redeposition of carbonate continued through the Neogene to the present day. Figure 7 is a summary of data from Site 313.

\section{REFERENCE}

Chase, T. E., Menard, H. W., and Mammerickx, J., 1971. Topography of the North Pacific: Institute of Marine Resources, University of California, San Diego. 


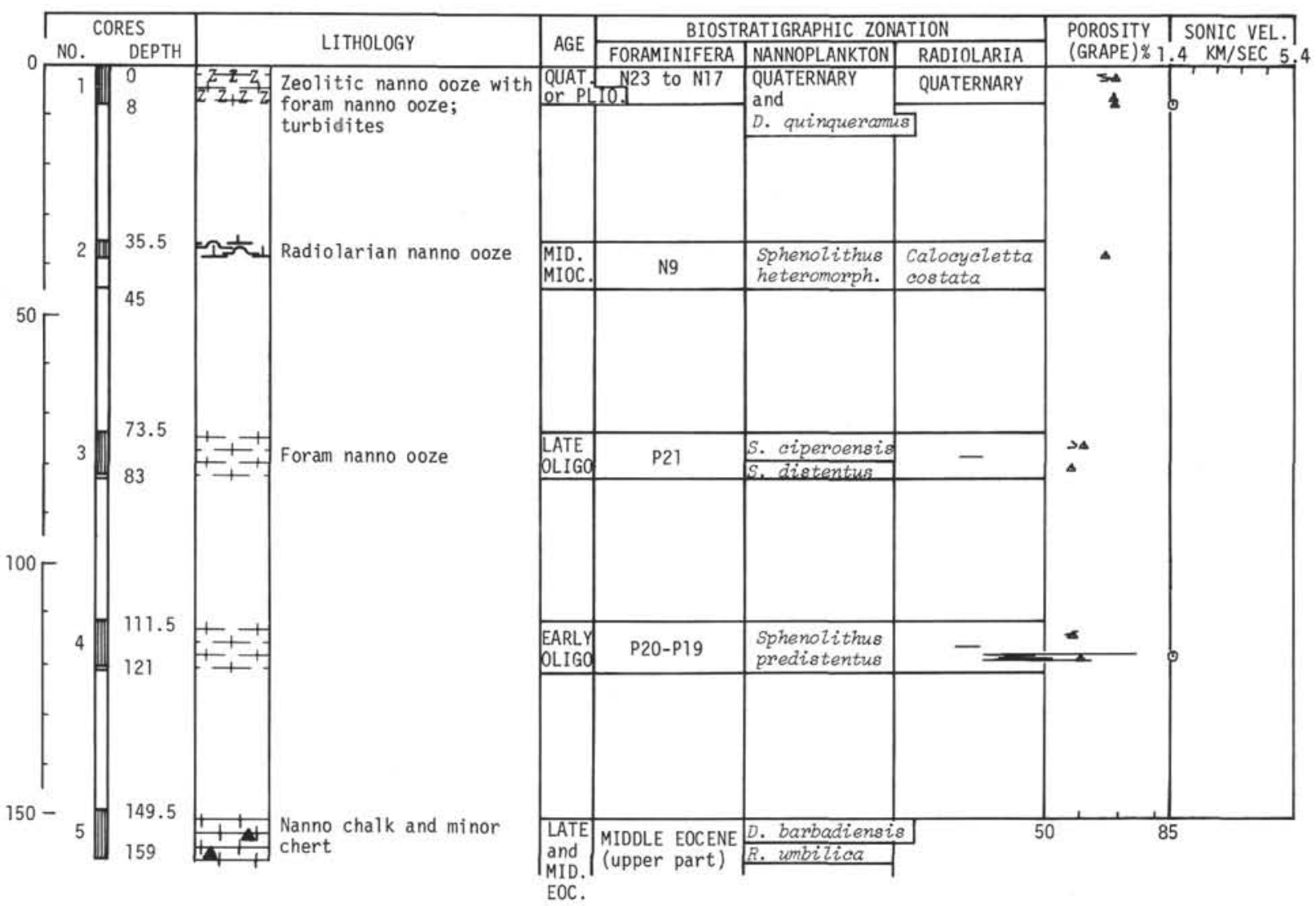

Figure 7. Summary of coring, lithology, biostratigraphy, and physical properties at Site 313.

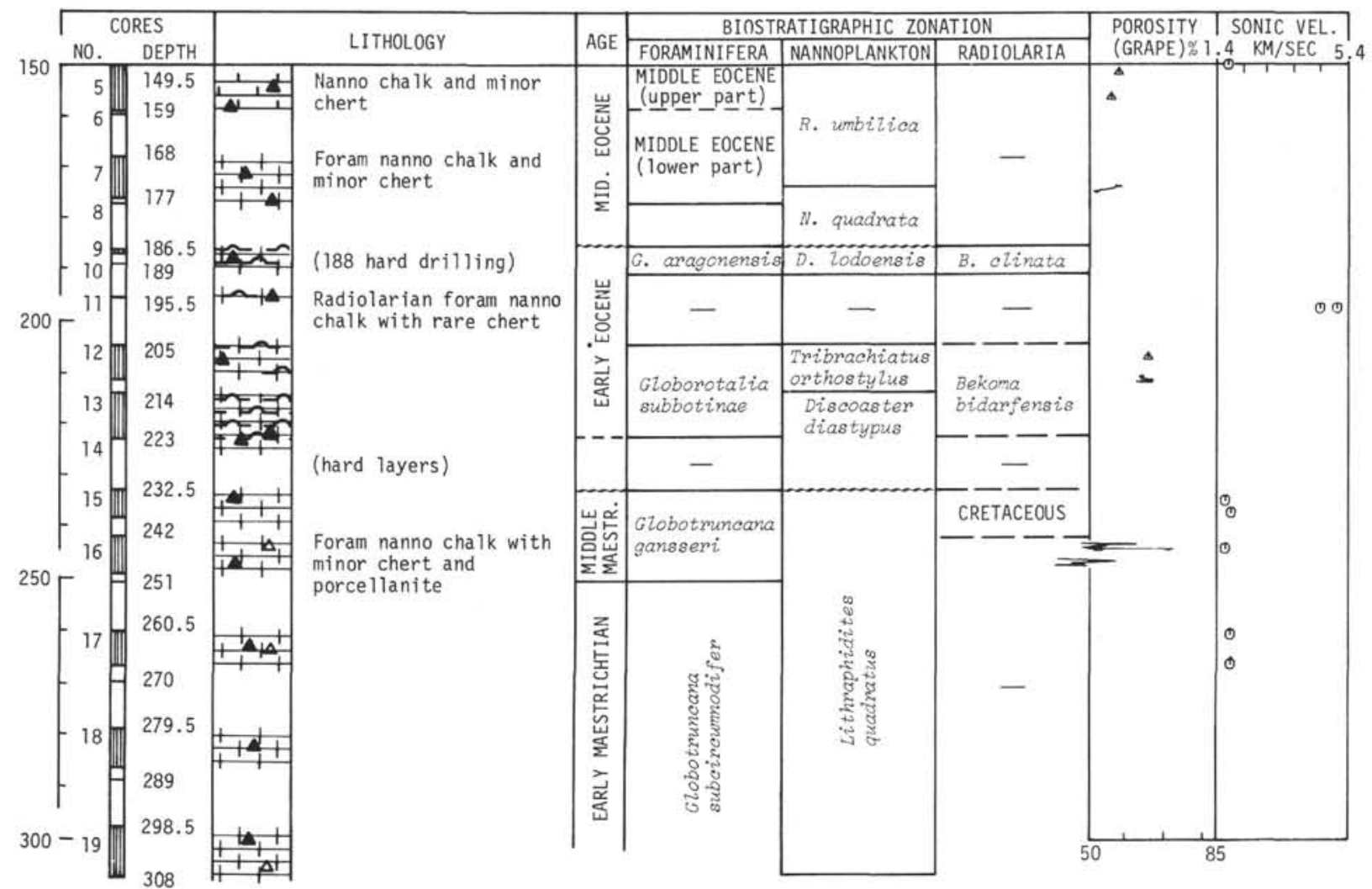

Figure 7. (Continued). 


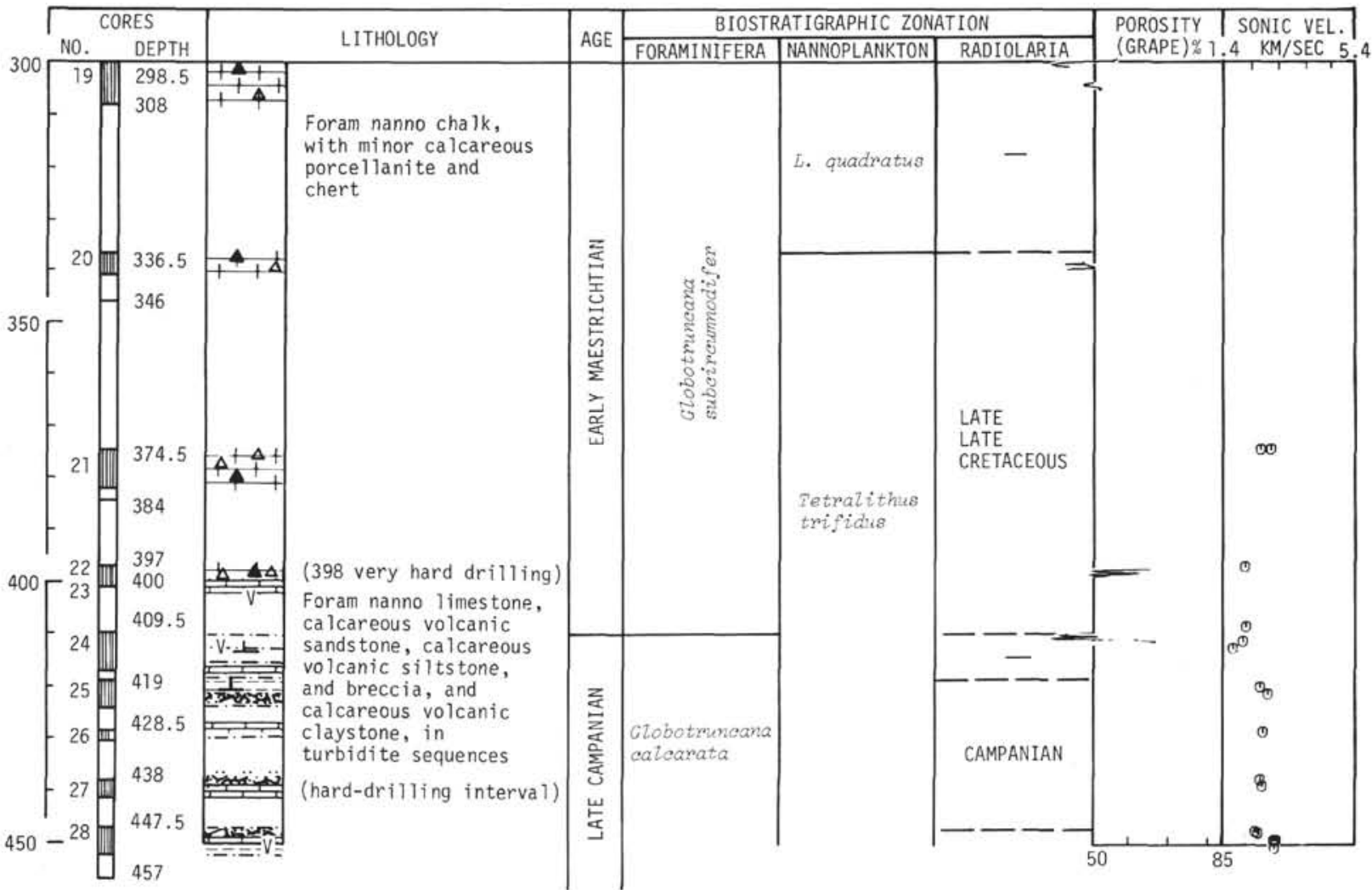

Figure 7. (Continued).

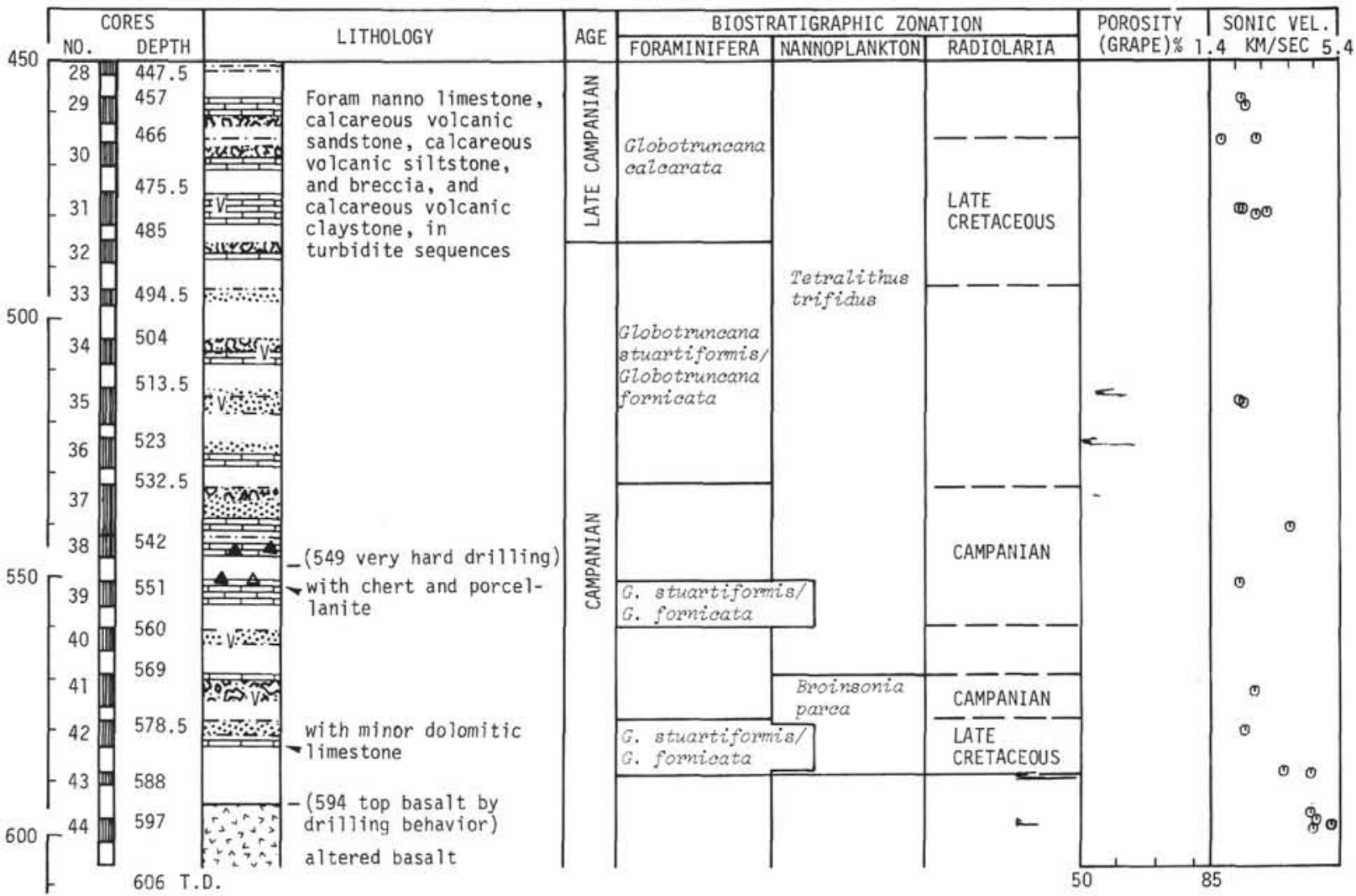

Figure 7. (Continued). 


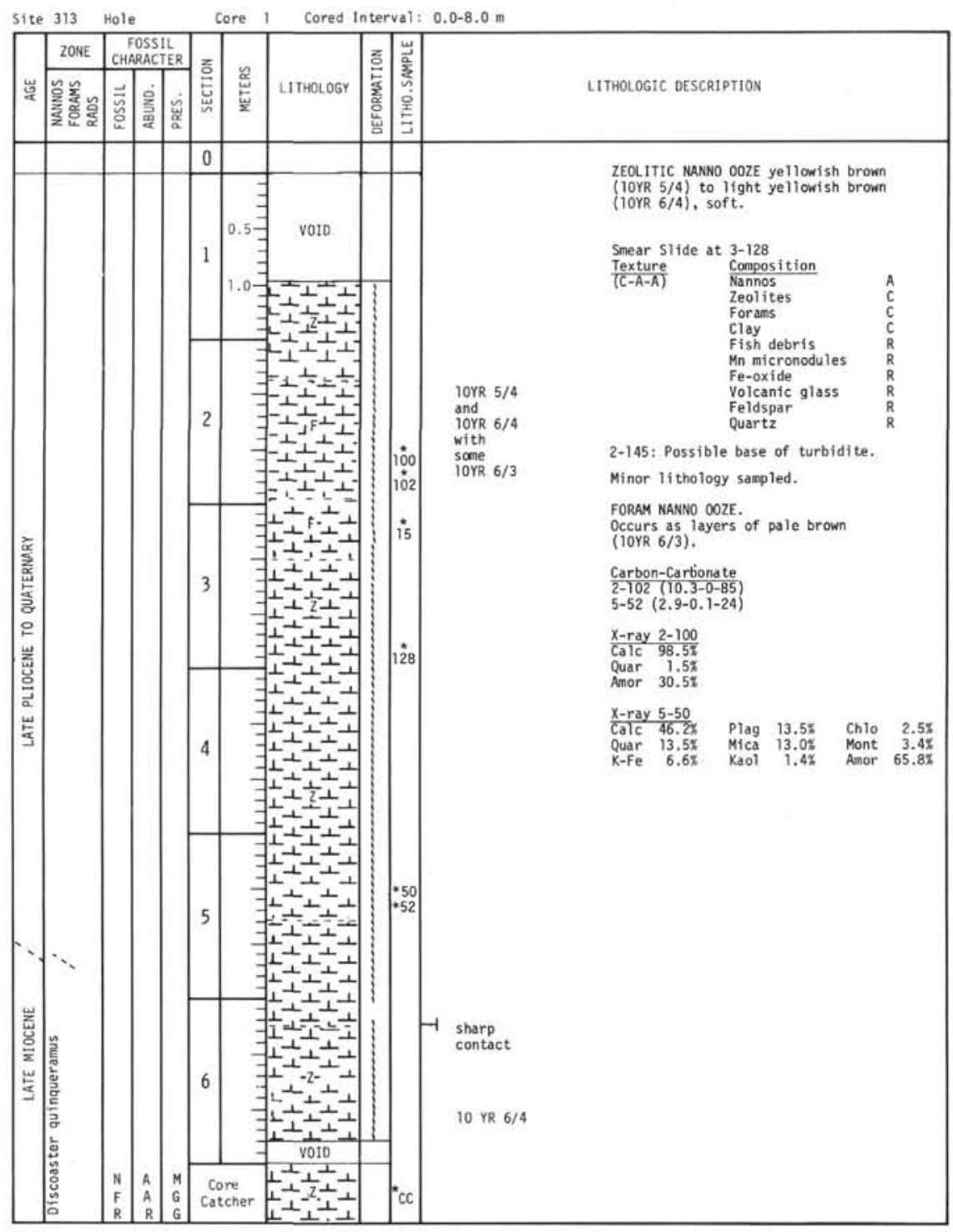

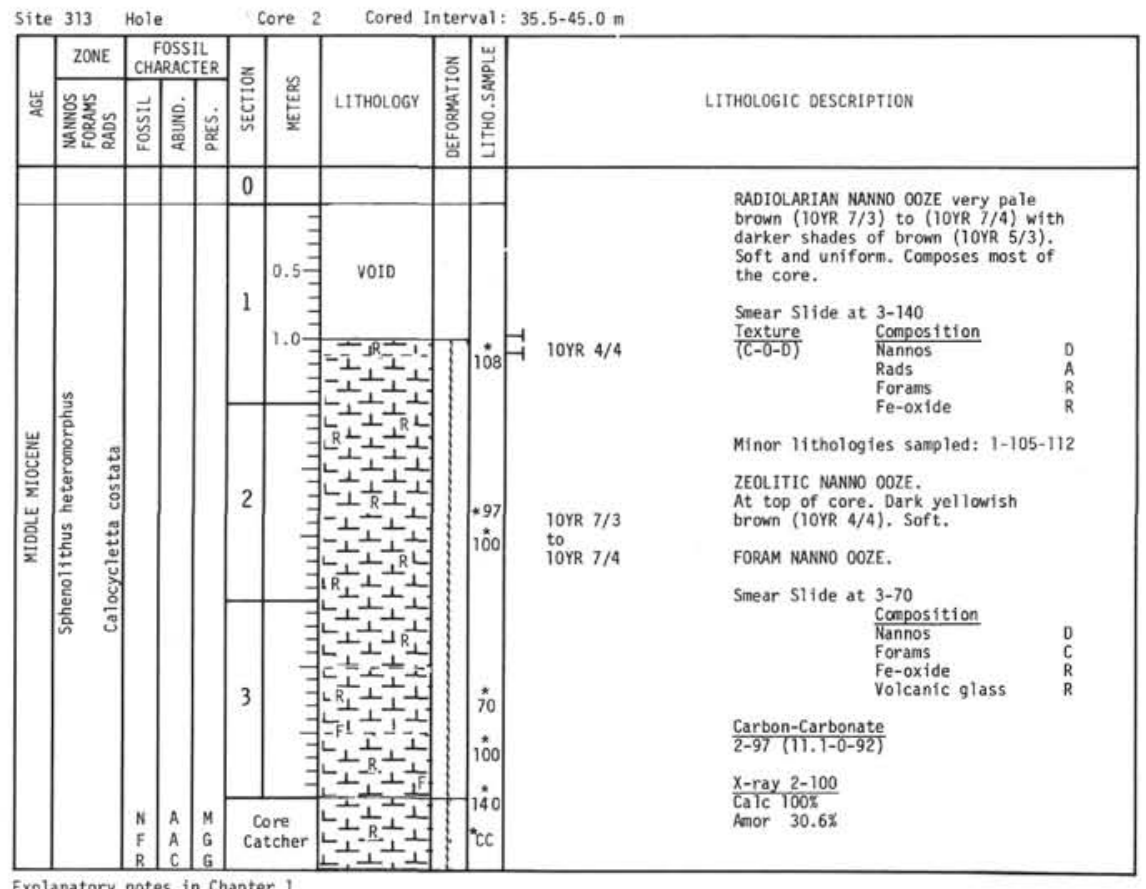




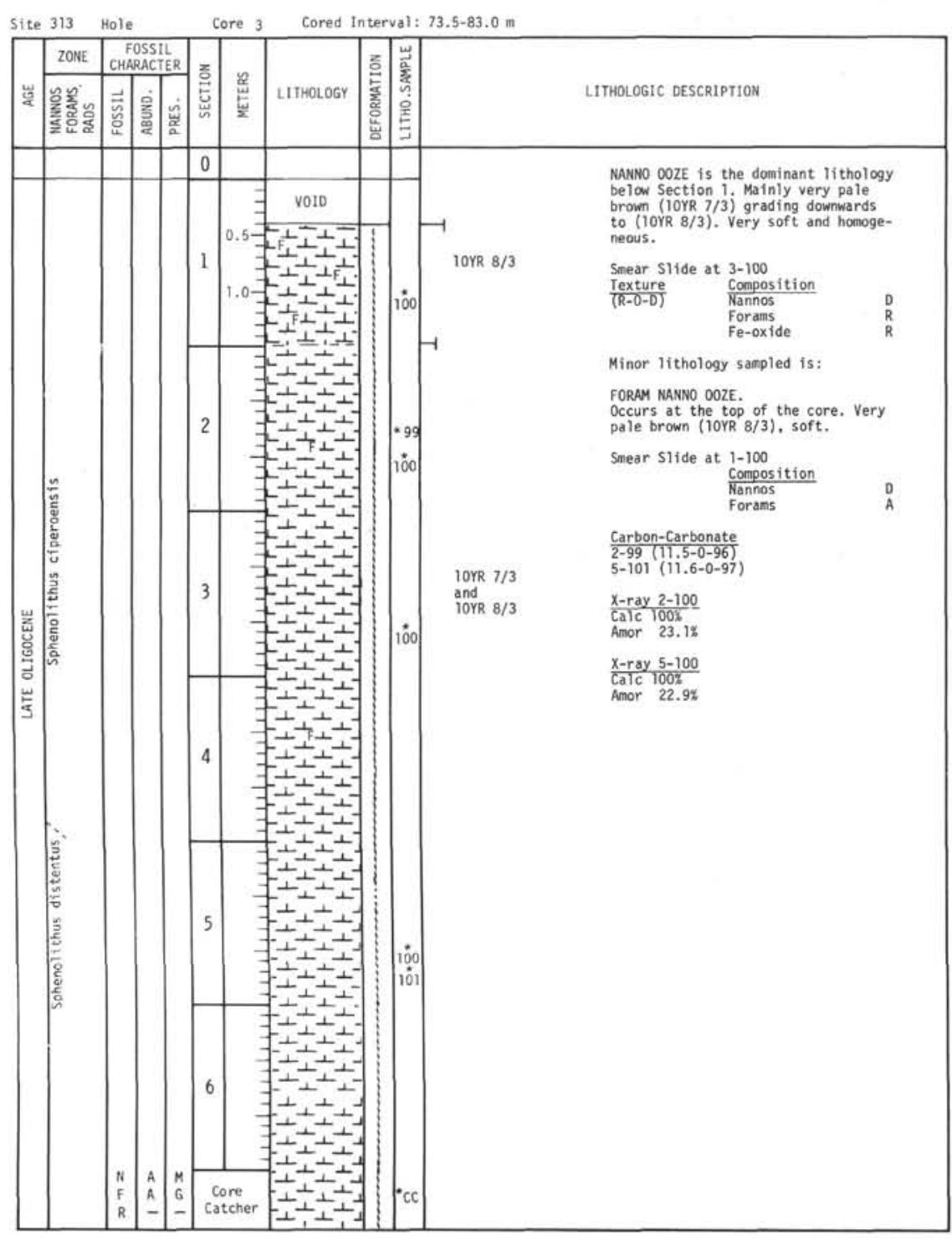

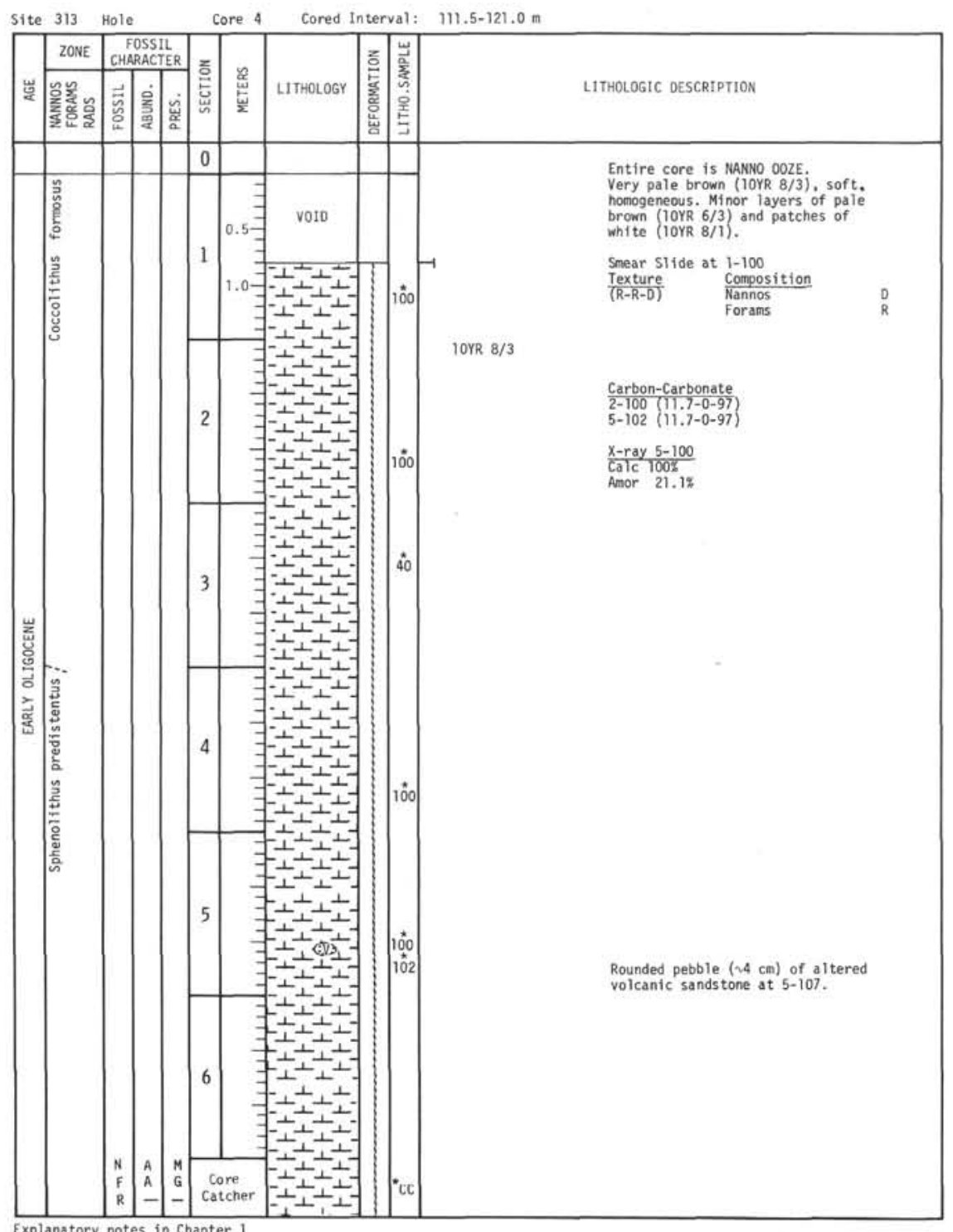




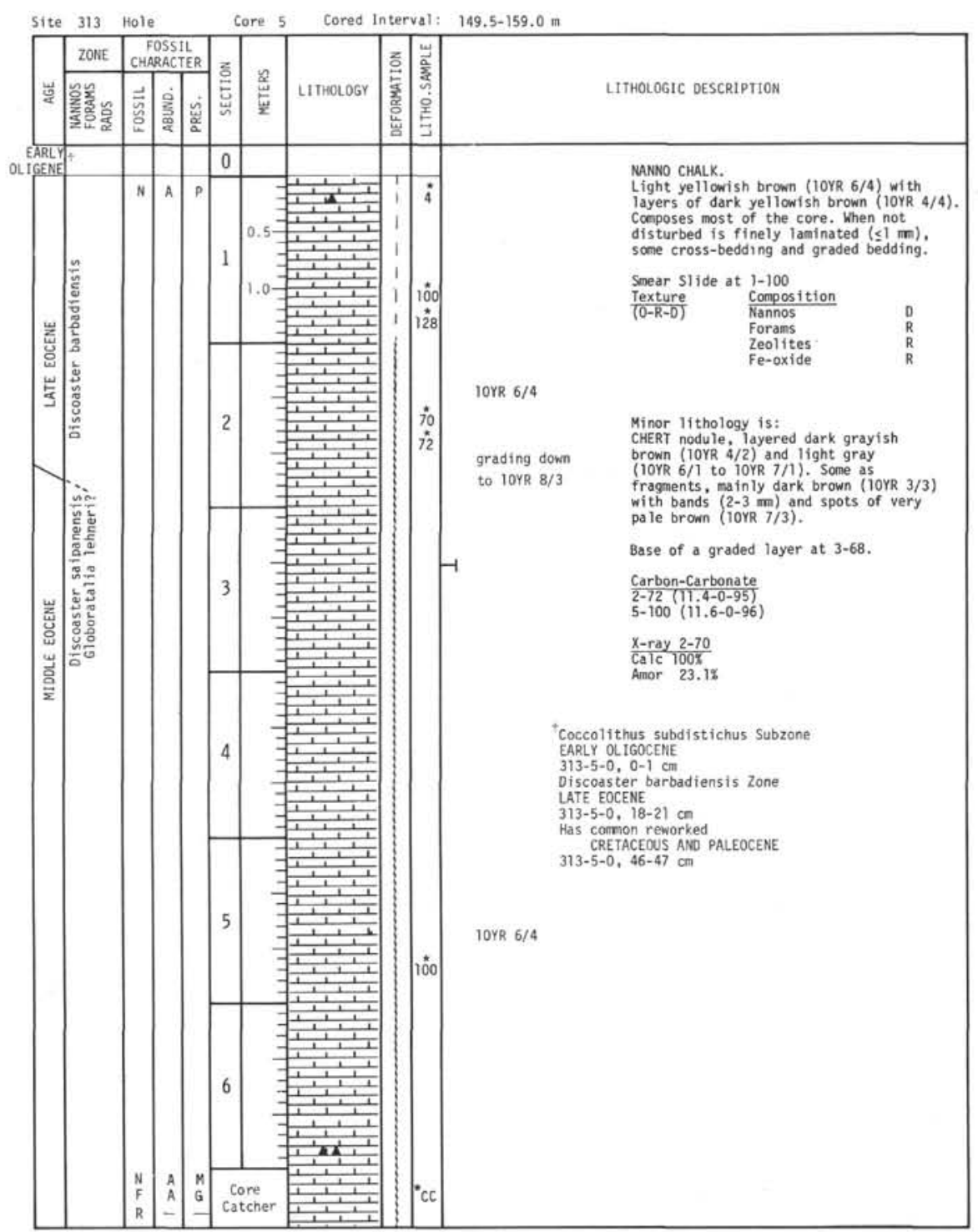

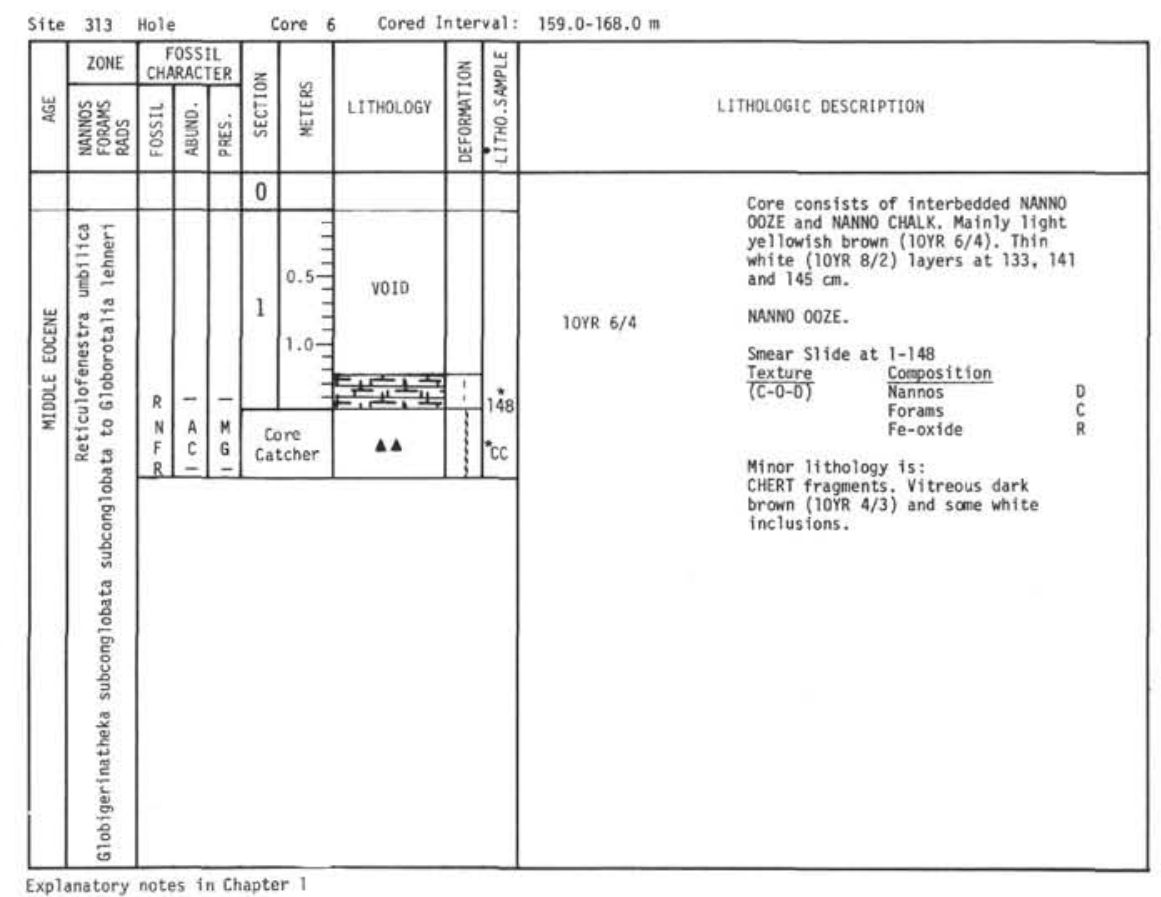


Site 313 Hole Core 8 Cored Interval: $177.0-186.5 \mathrm{~m}$

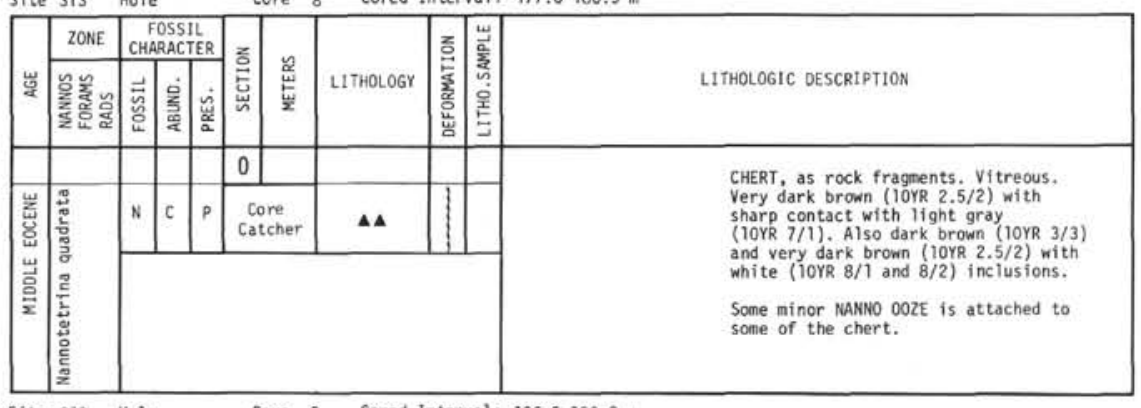

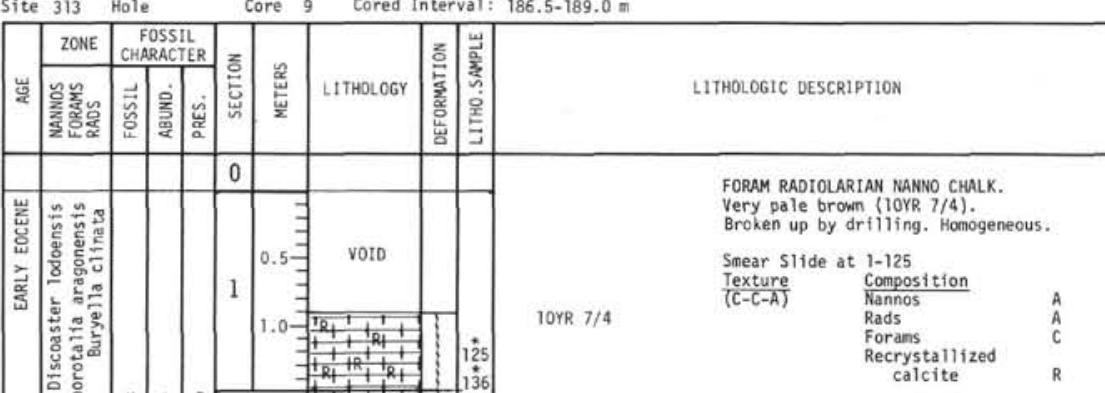

Minor 1 ithology is:

CHERT, as fragments. Very dark gray
$\left(10 Y R^{3} 3 / 1\right)$ and brown (10YR $\left.4 / 3\right)$ with finely laminstef with sh with partly silicified very pale brom

$\frac{\text { Carbon-Carbonate }}{-136-(8,9-0-70)}$

\begin{tabular}{|c|c|c|c|c|c|c|c|c|c|}
\hline \multicolumn{2}{|c|}{ Site 313} & \multicolumn{3}{|c|}{ Hole } & Core 10 & \multicolumn{3}{|c|}{ Cored Interval: $189.0-195.5 \mathrm{~m}$} & \multirow[b]{3}{*}{ LITHOLOGIC DESCRIPTION } \\
\hline & ZONE & \multicolumn{3}{|c|}{$\begin{array}{r}\text { FOSSIL } \\
\text { CHARACTER }\end{array}$} & \multirow[b]{2}{*}{ 奠 } & \multirow[b]{2}{*}{ LITHOLOGY } & \multirow{2}{*}{ 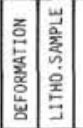 } & & \\
\hline 岁 & 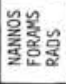 & 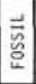 & & & & & & & \\
\hline & & & & & 0 & & & & \multirow{2}{*}{ 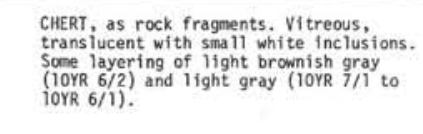 } \\
\hline & & N & - & - & $\begin{array}{c}\text { Core } \\
\text { Catcher }\end{array}$ & ${ }^{4}$ & & & \\
\hline
\end{tabular}




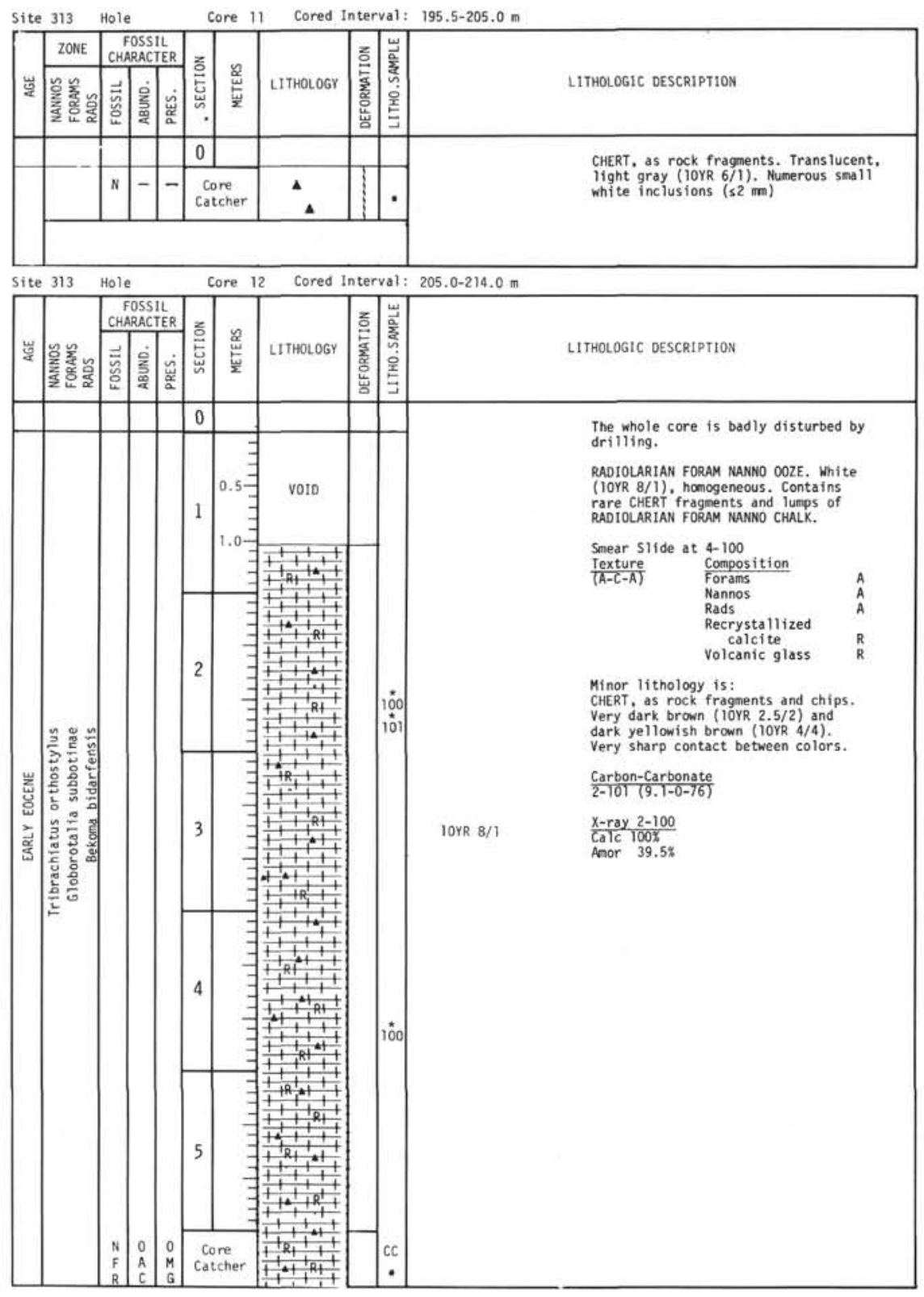

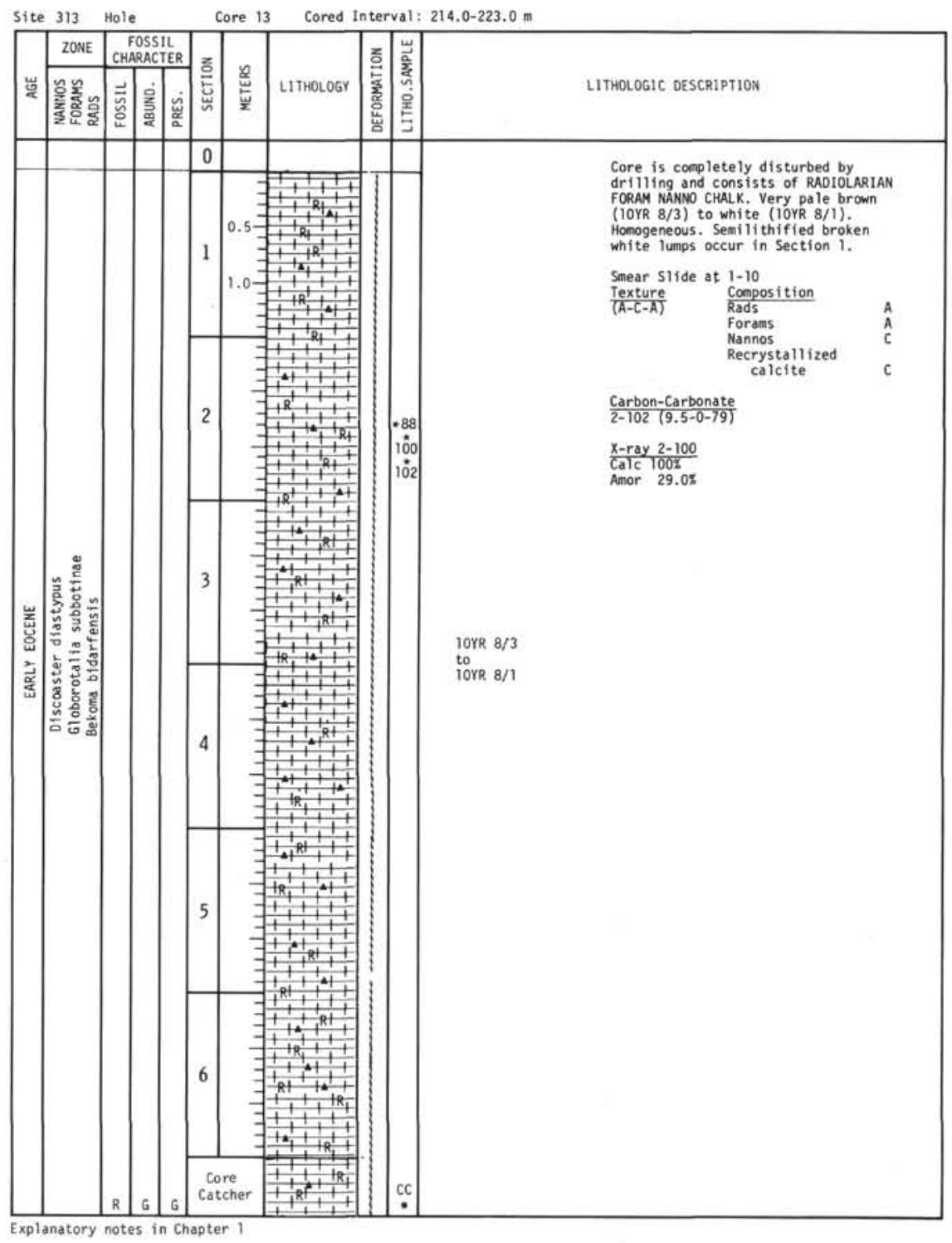




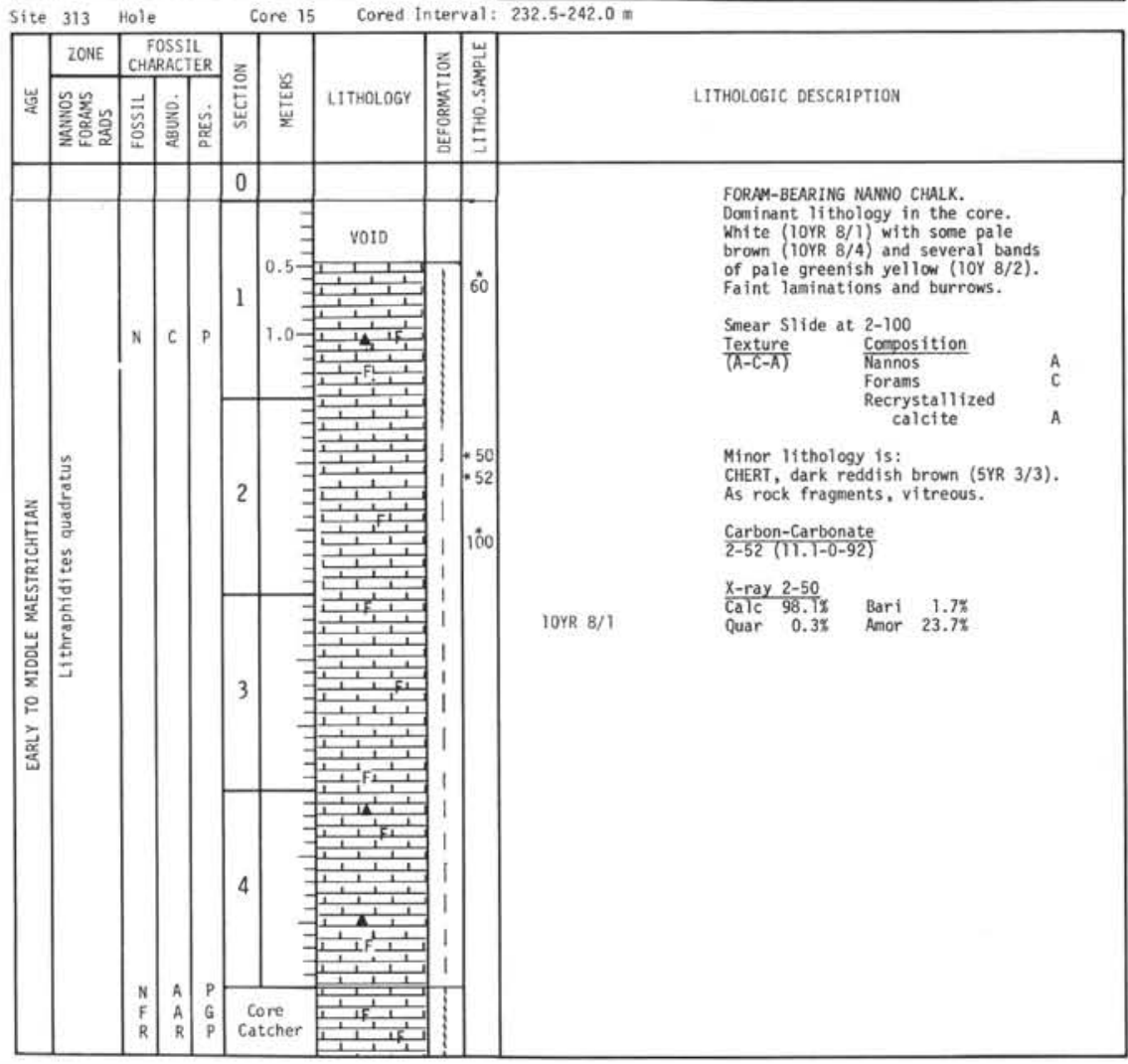

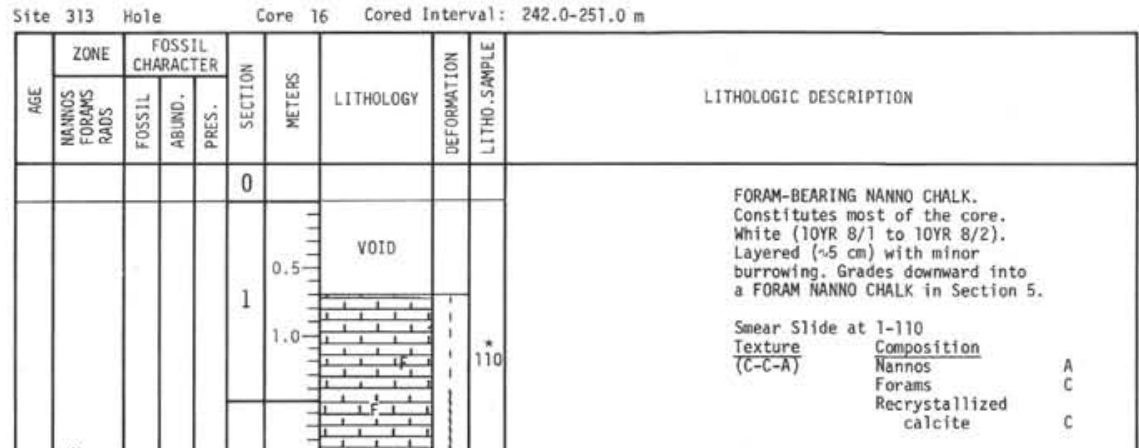

Minor 11 thnology is:

CHERT, as rock fragments. Light dark brown (7.5YR 4/4). Curved outer surface of notule present $\frac{\text { Carbon-carbonate }}{2-95(111.5-0.95)}$

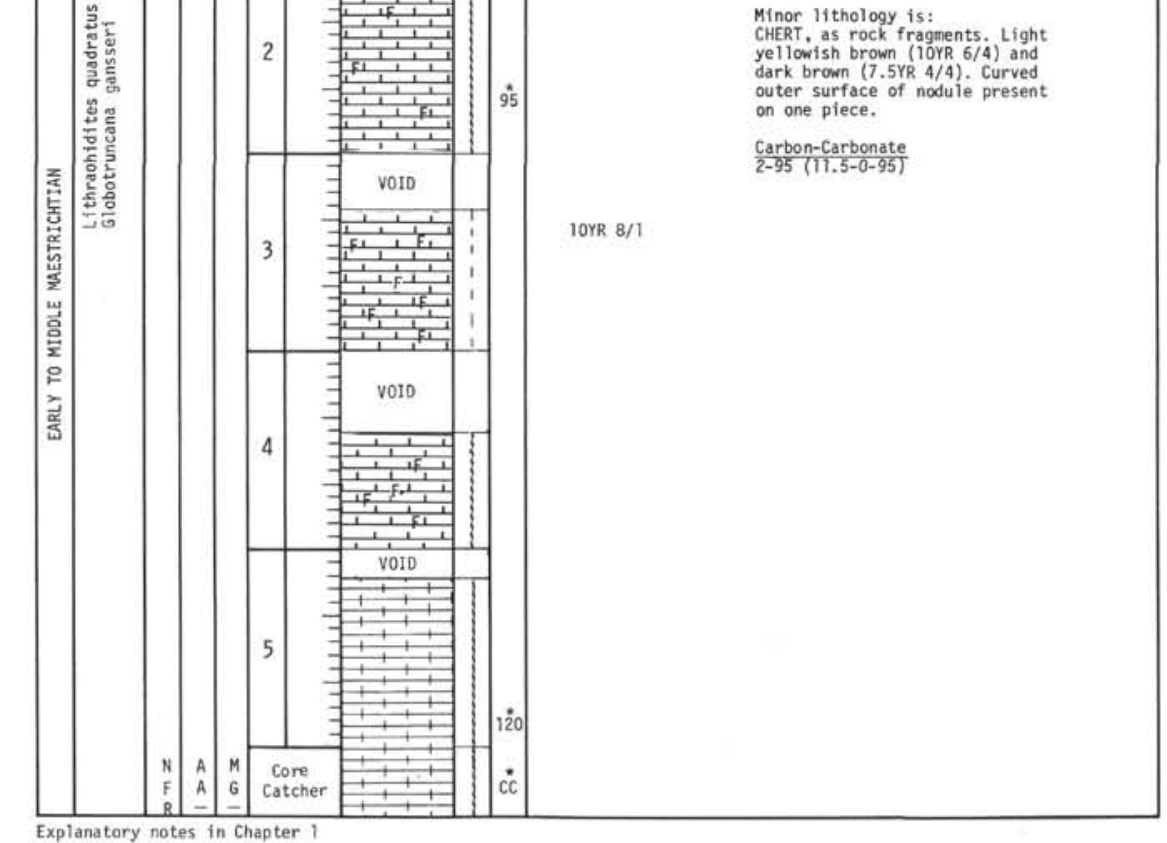




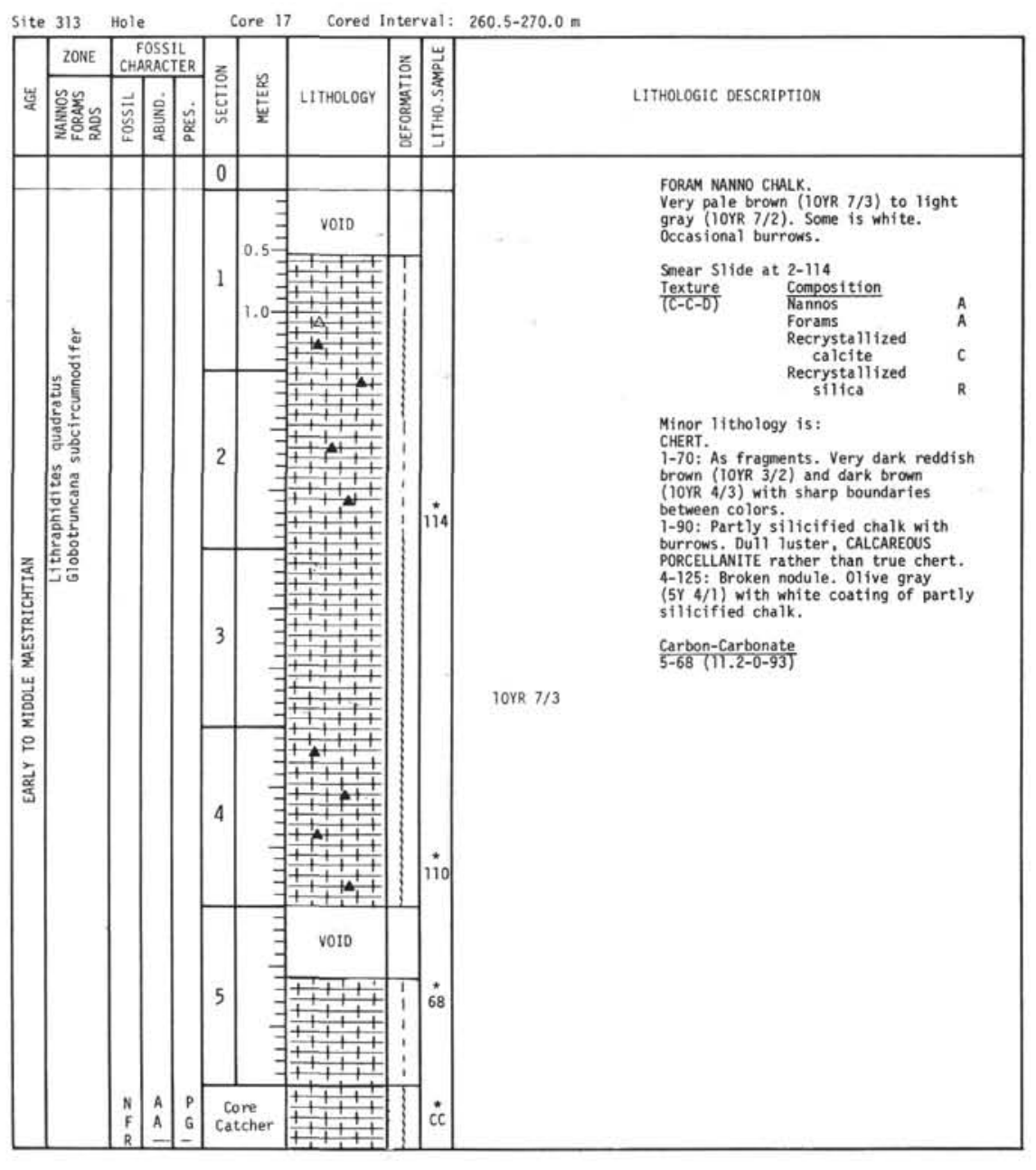

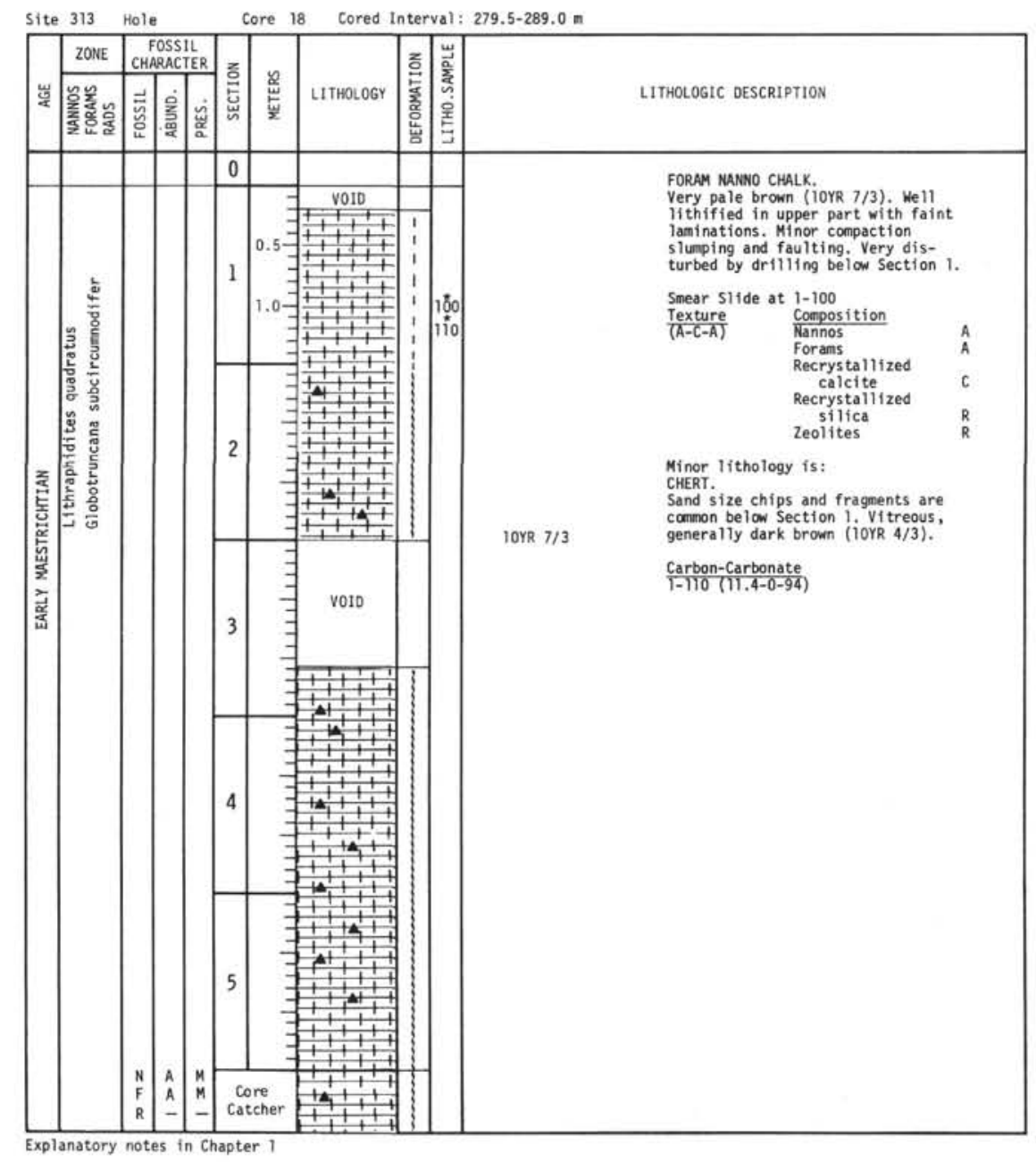




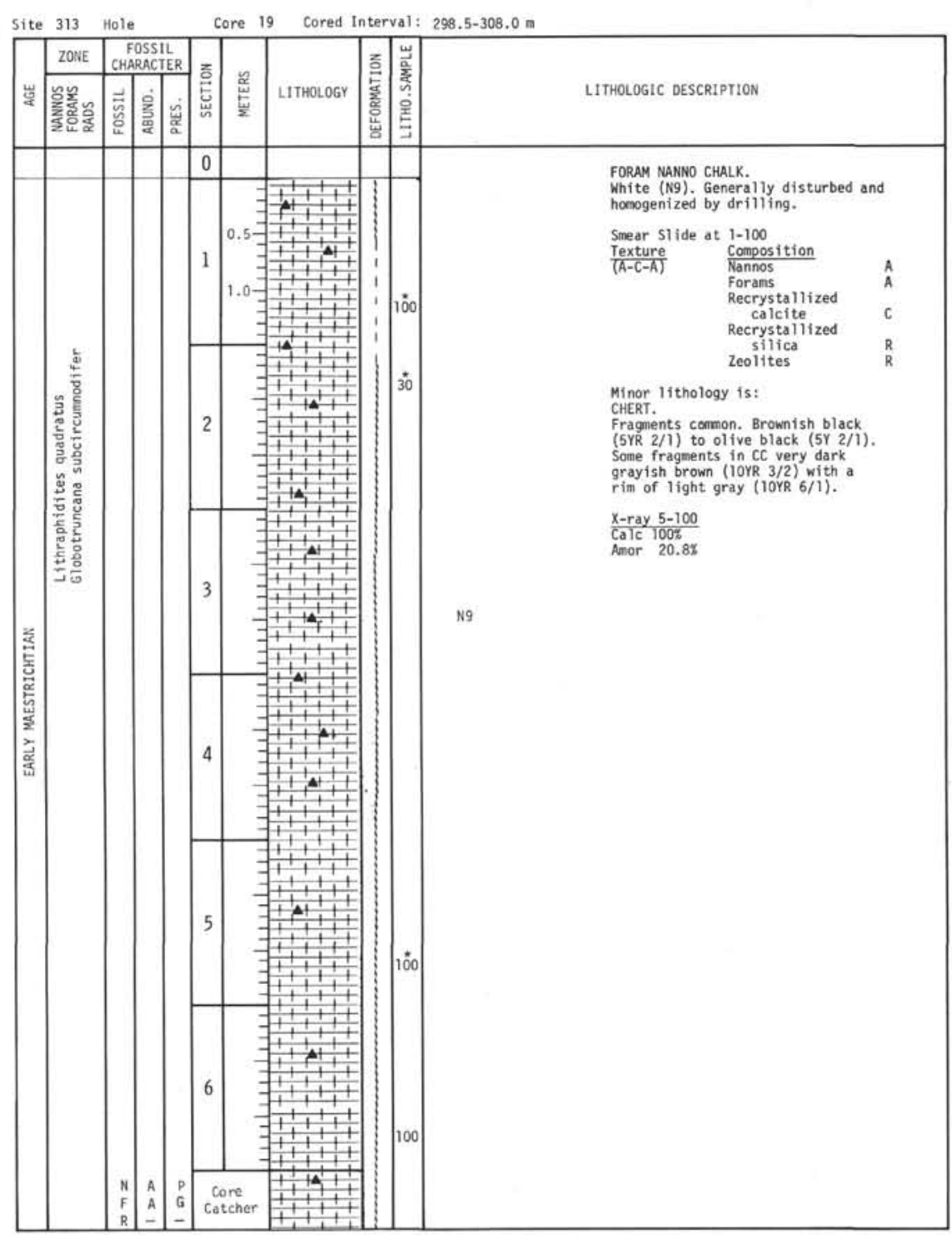

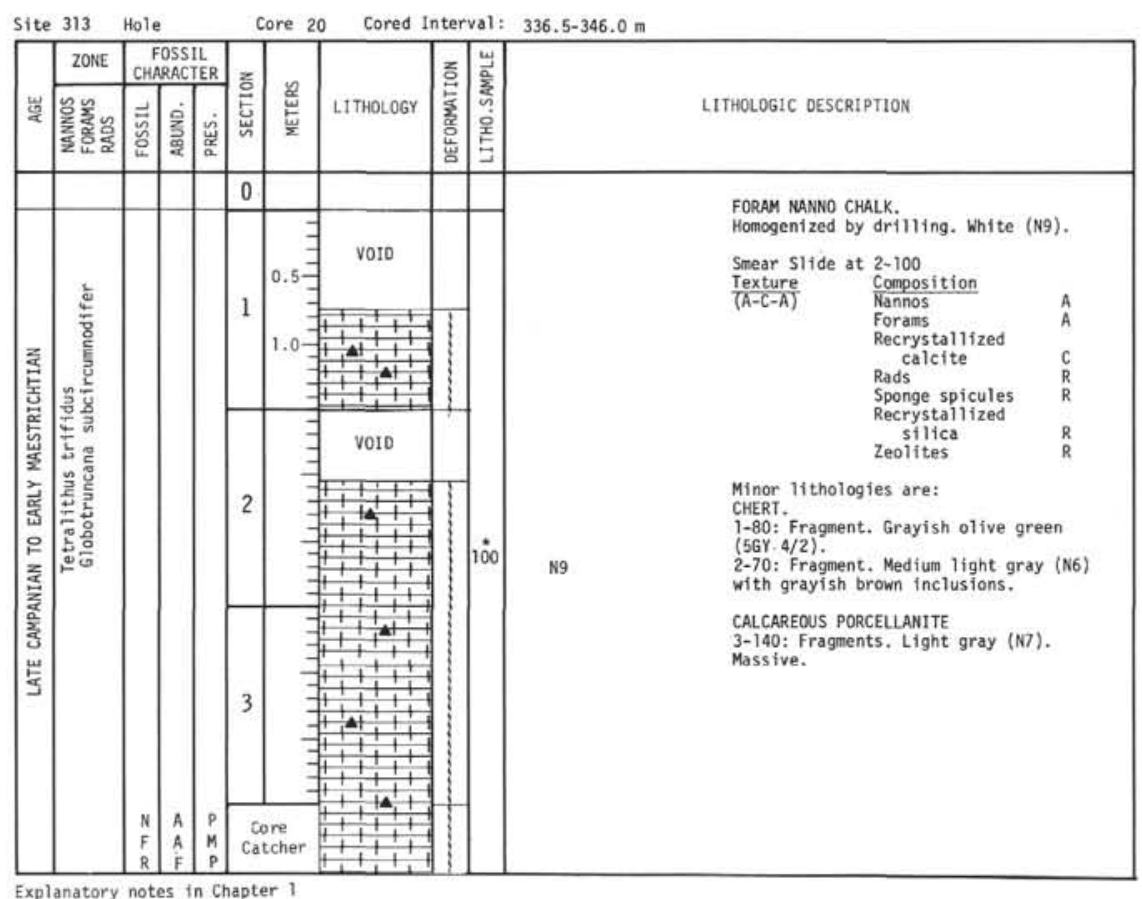




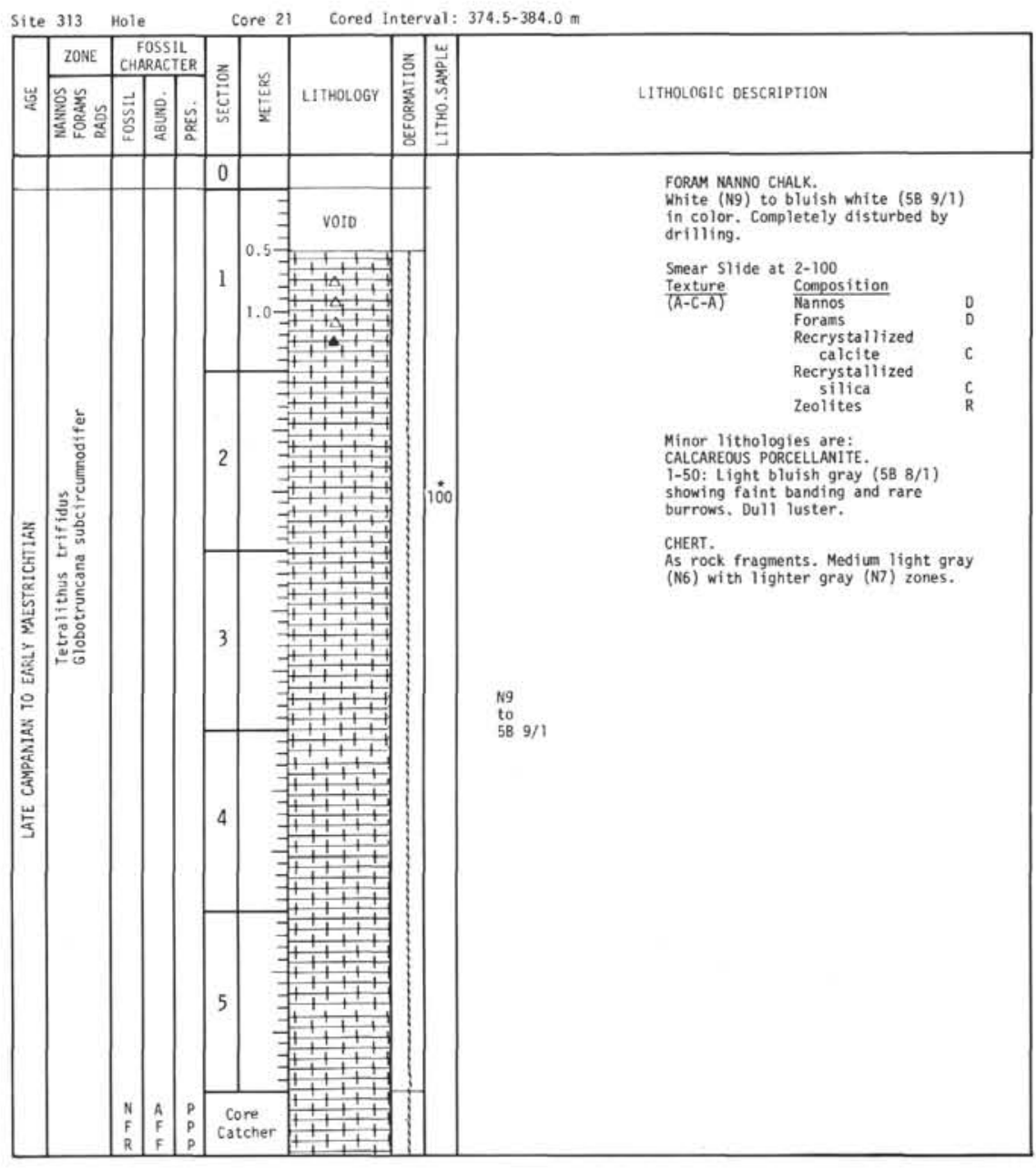

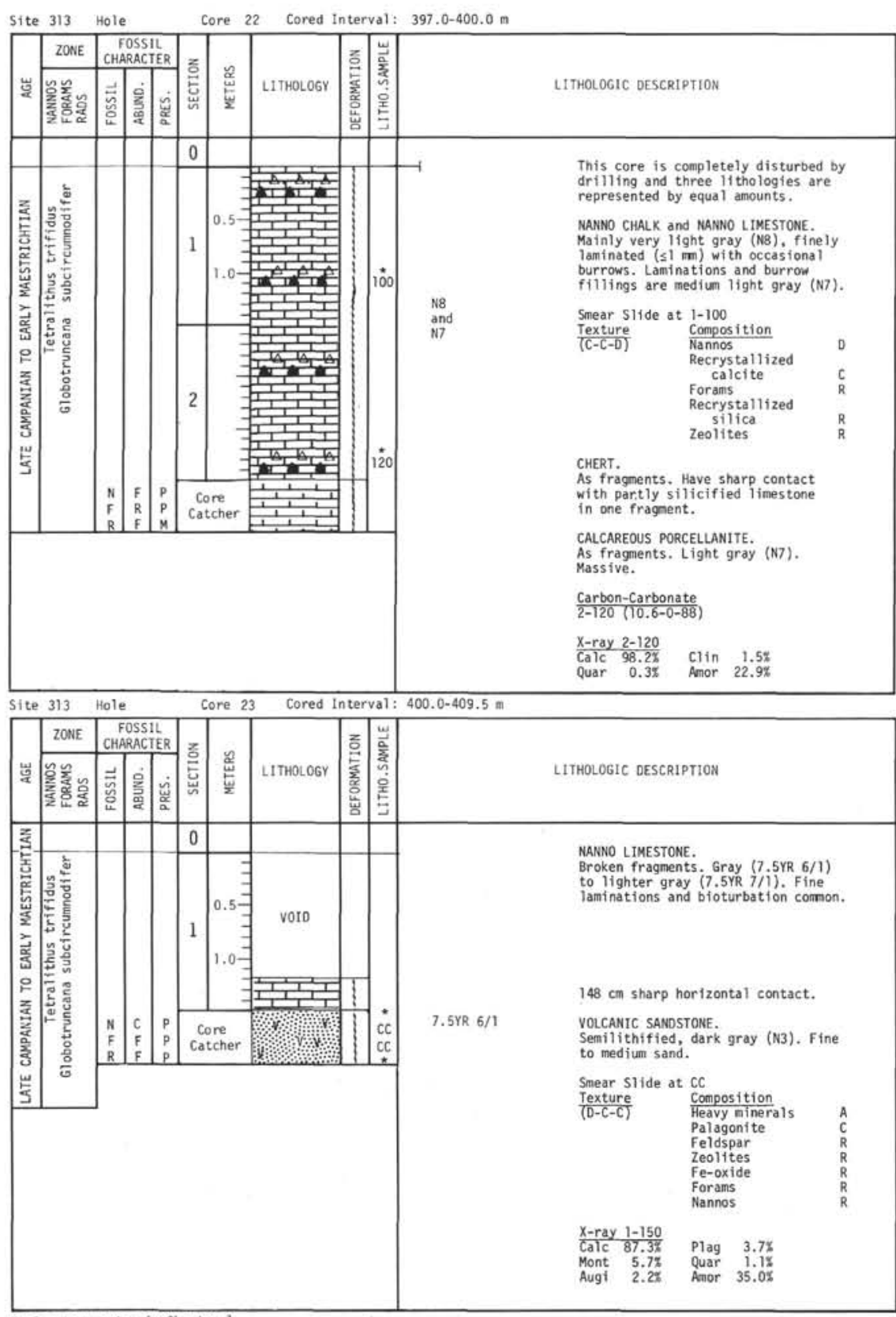

Explanatory notes in Chapter 


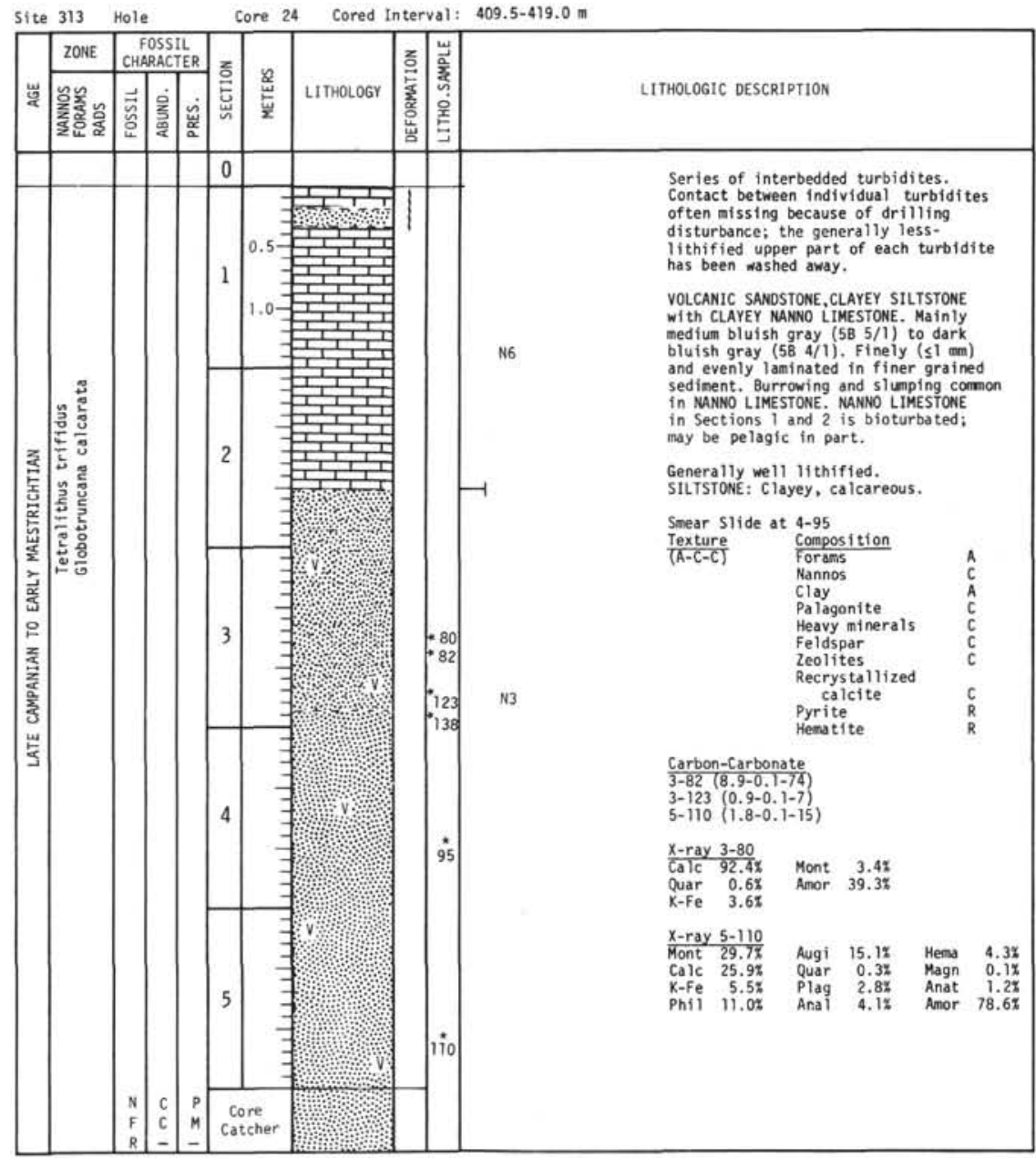

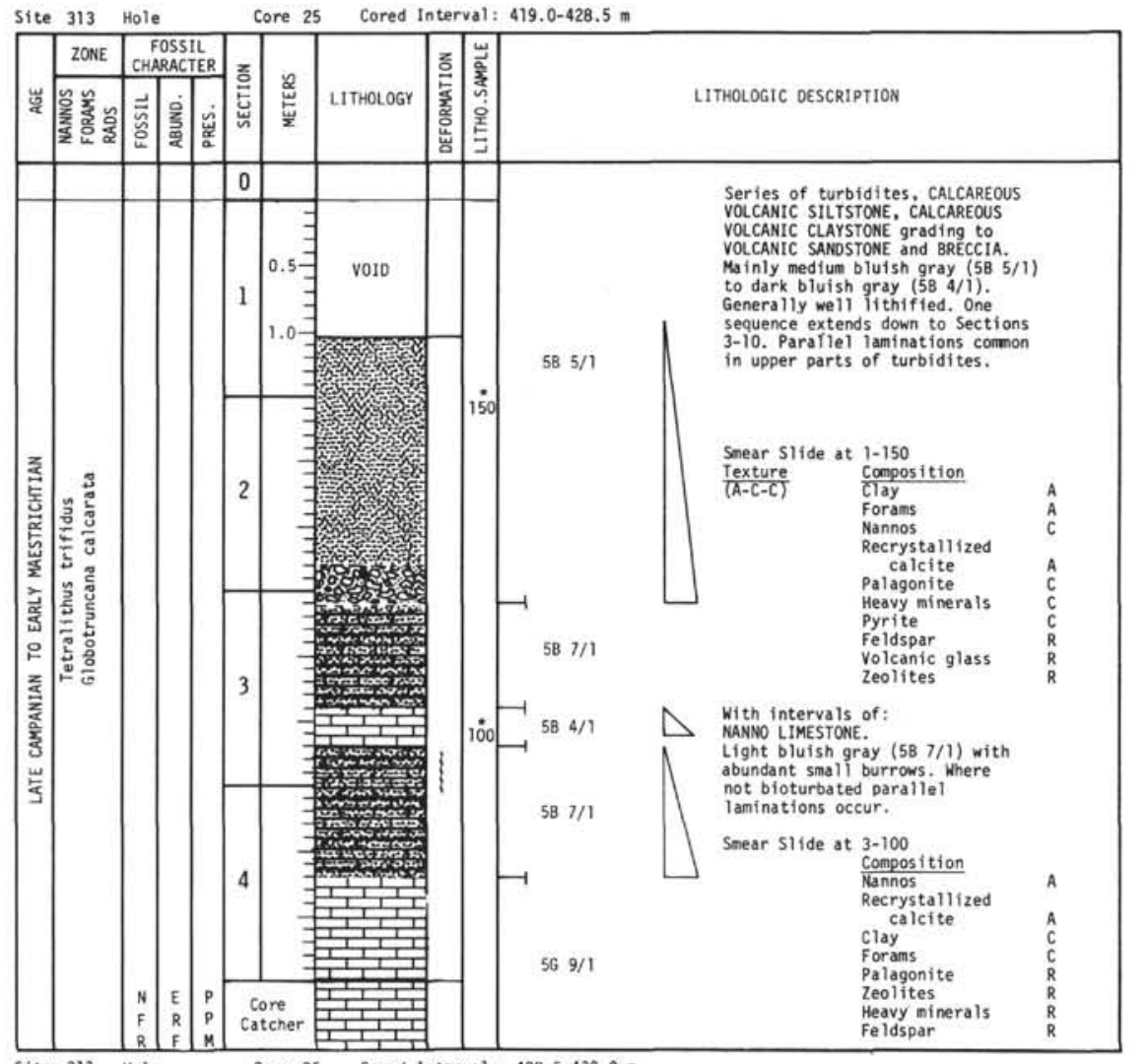

\begin{tabular}{|l|l|l|l|l|l|l|}
\hline Site 313 & Hole \\
\hline
\end{tabular}




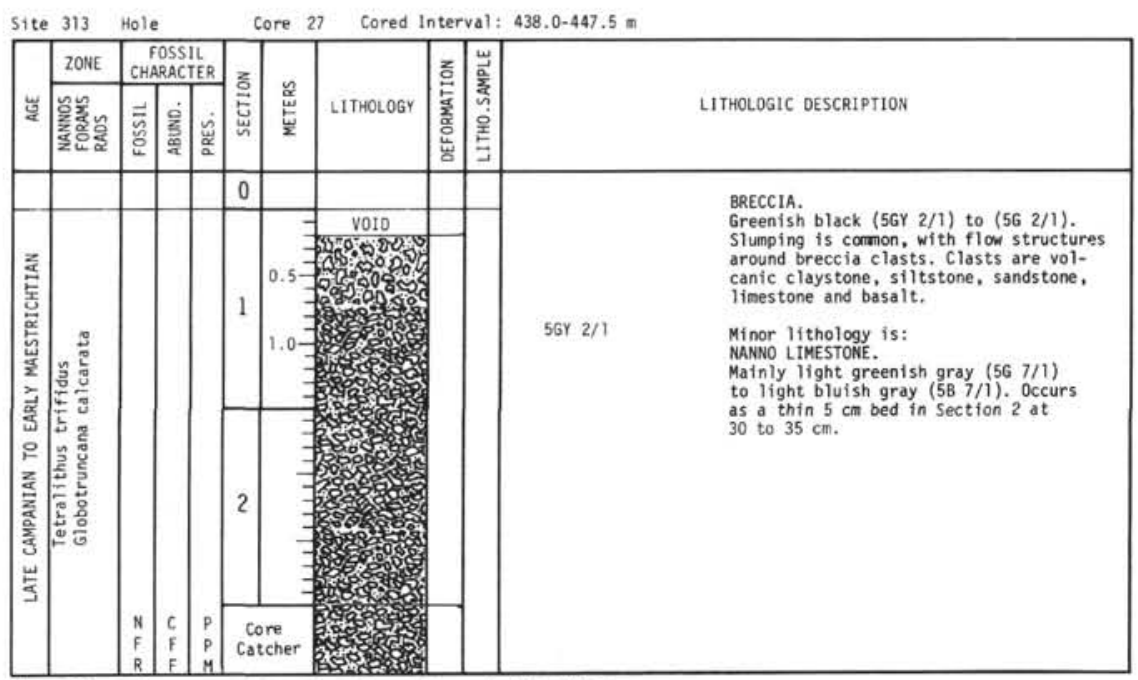

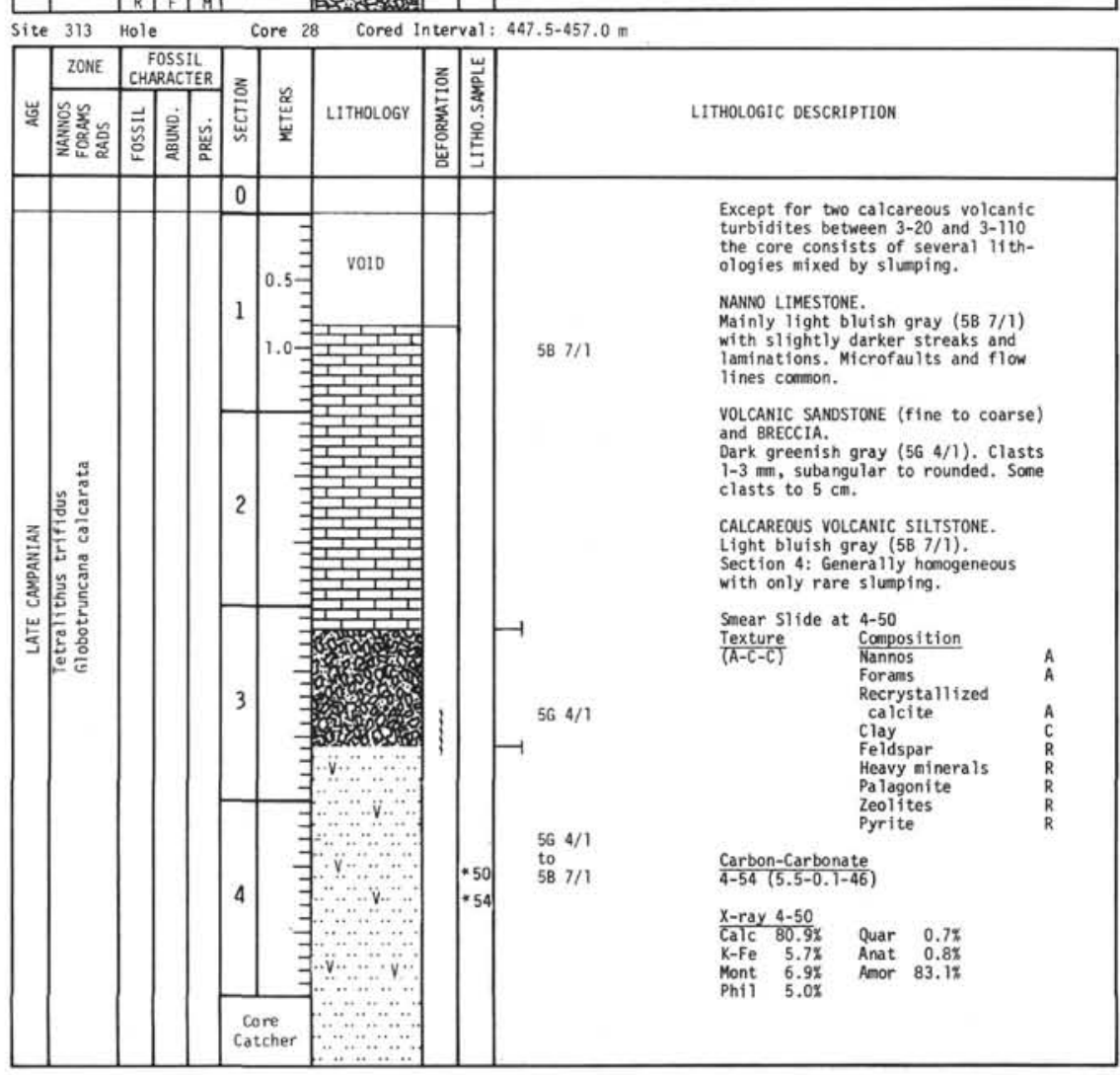

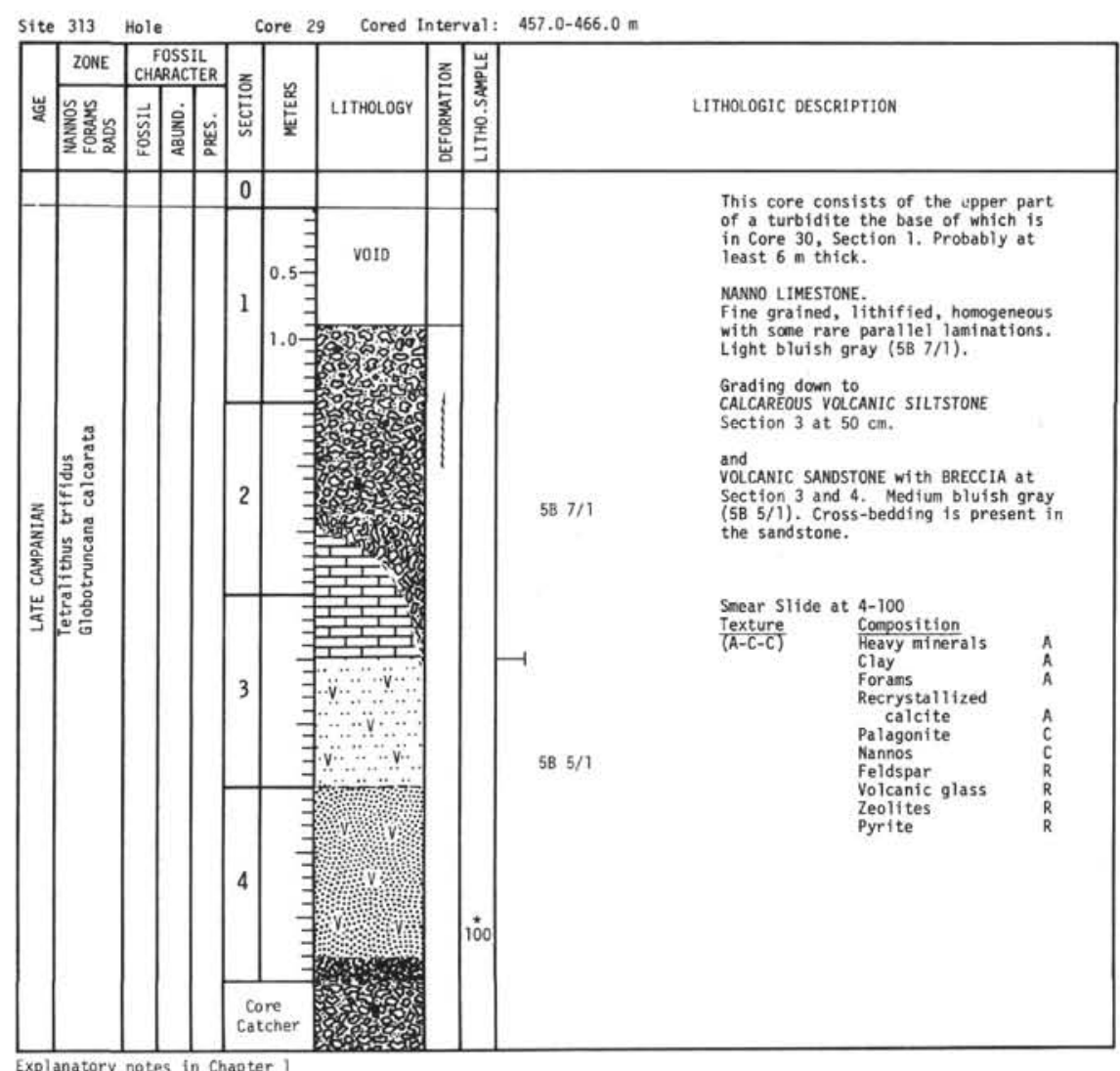

Explanatory notes in Chapter 1 


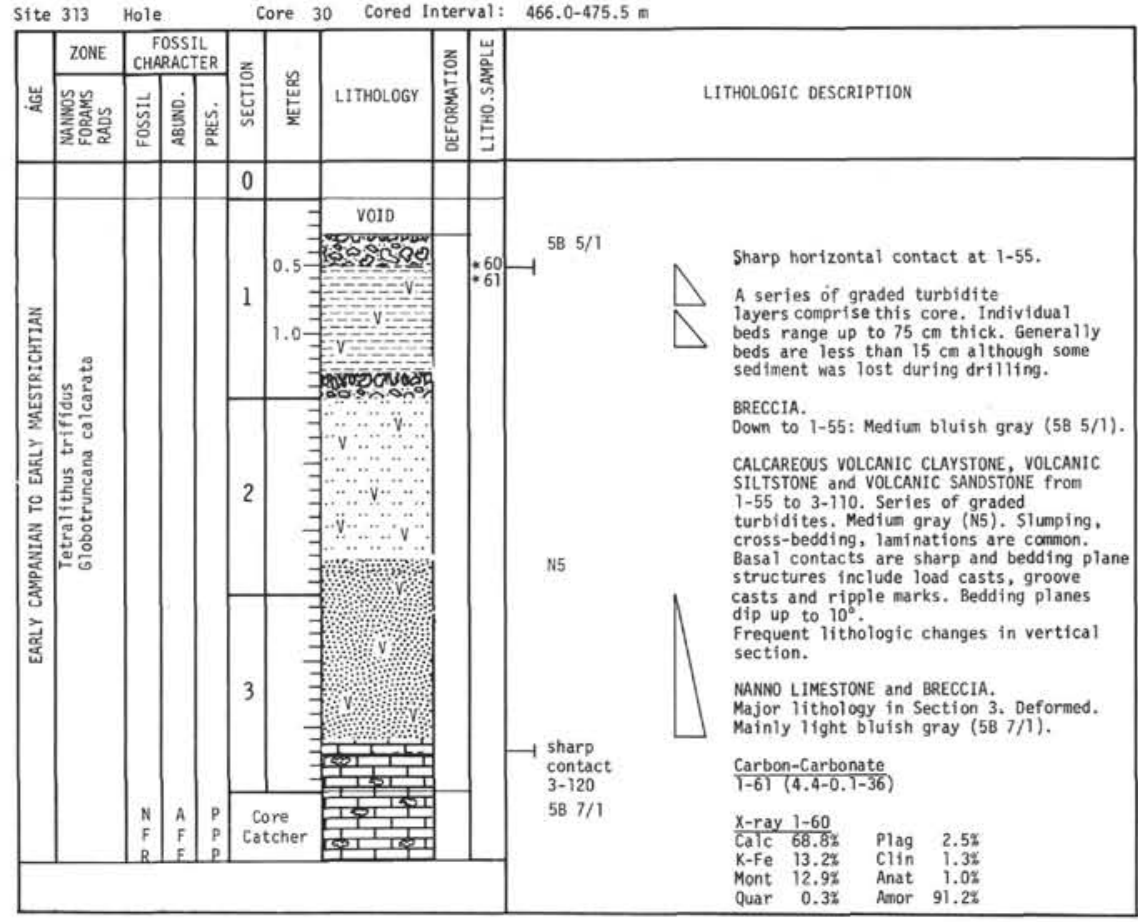

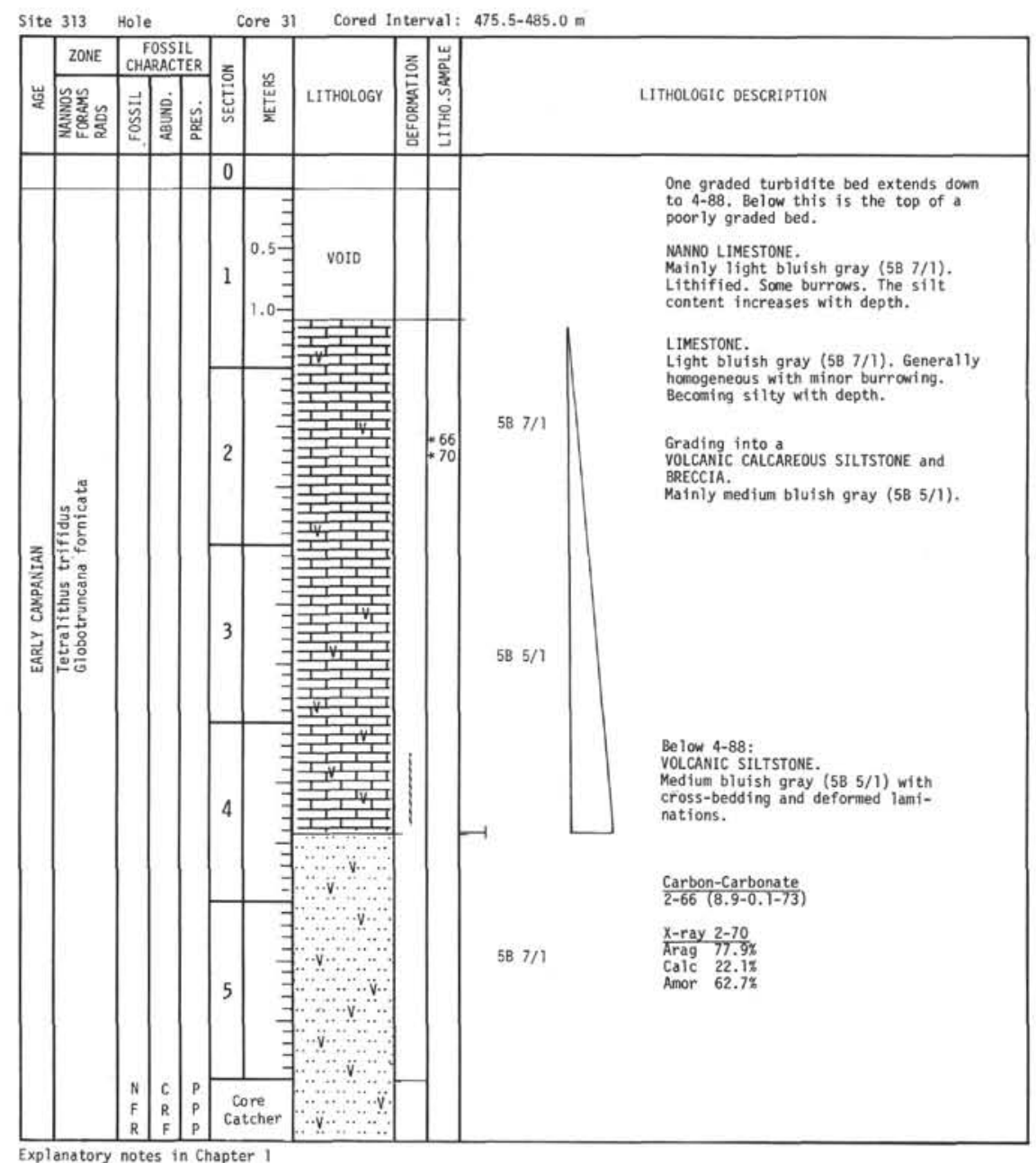




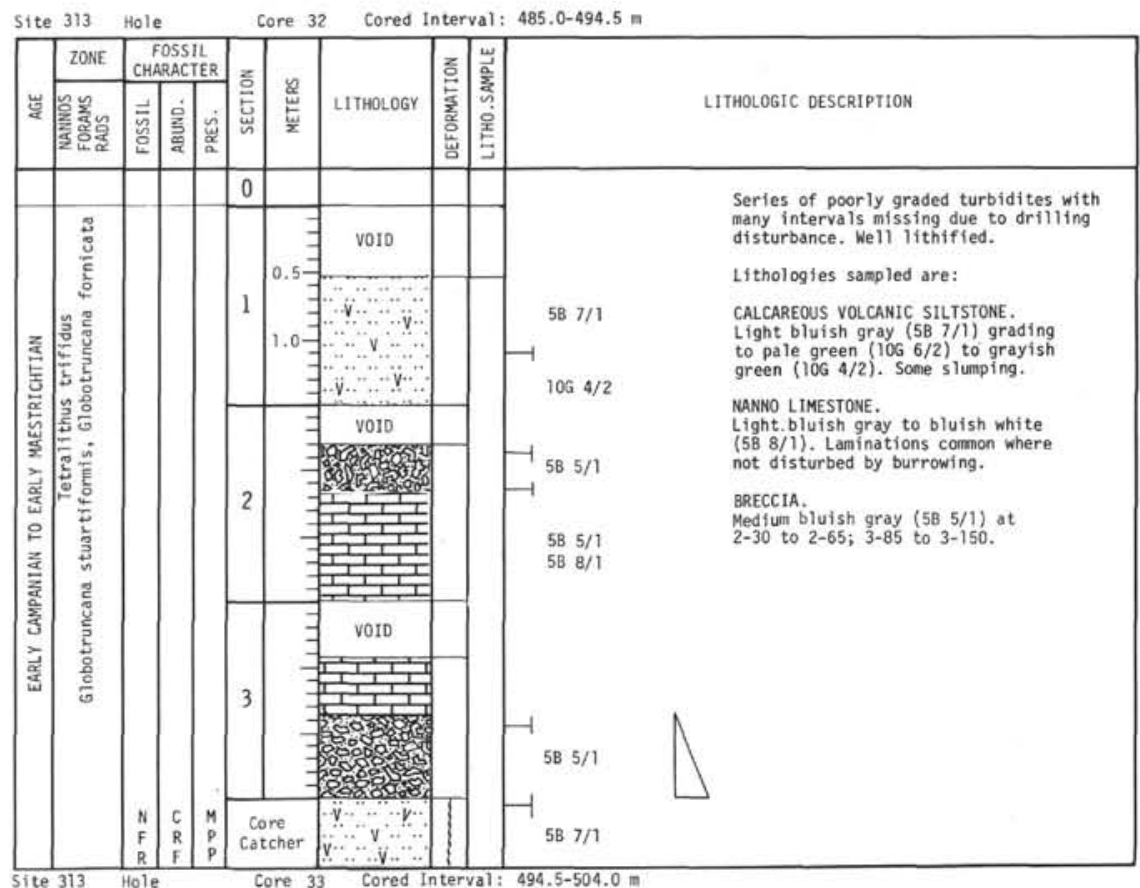

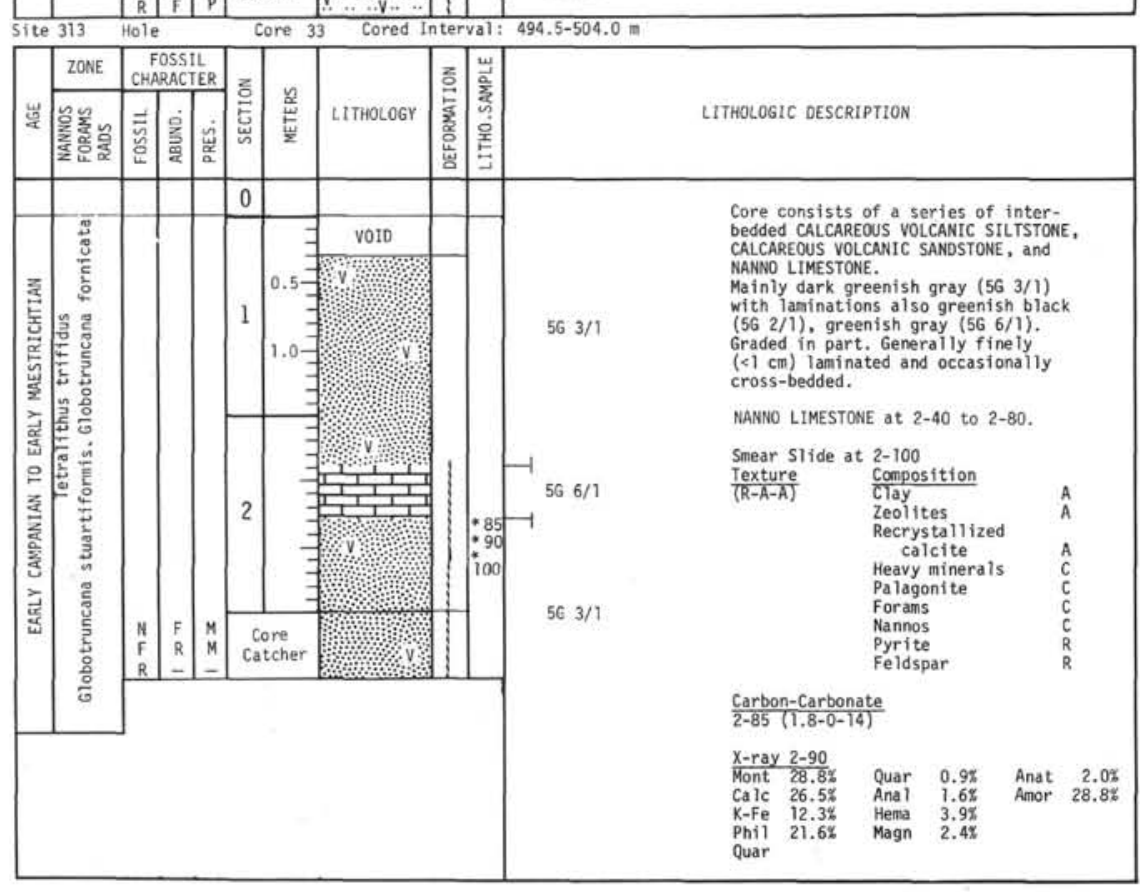

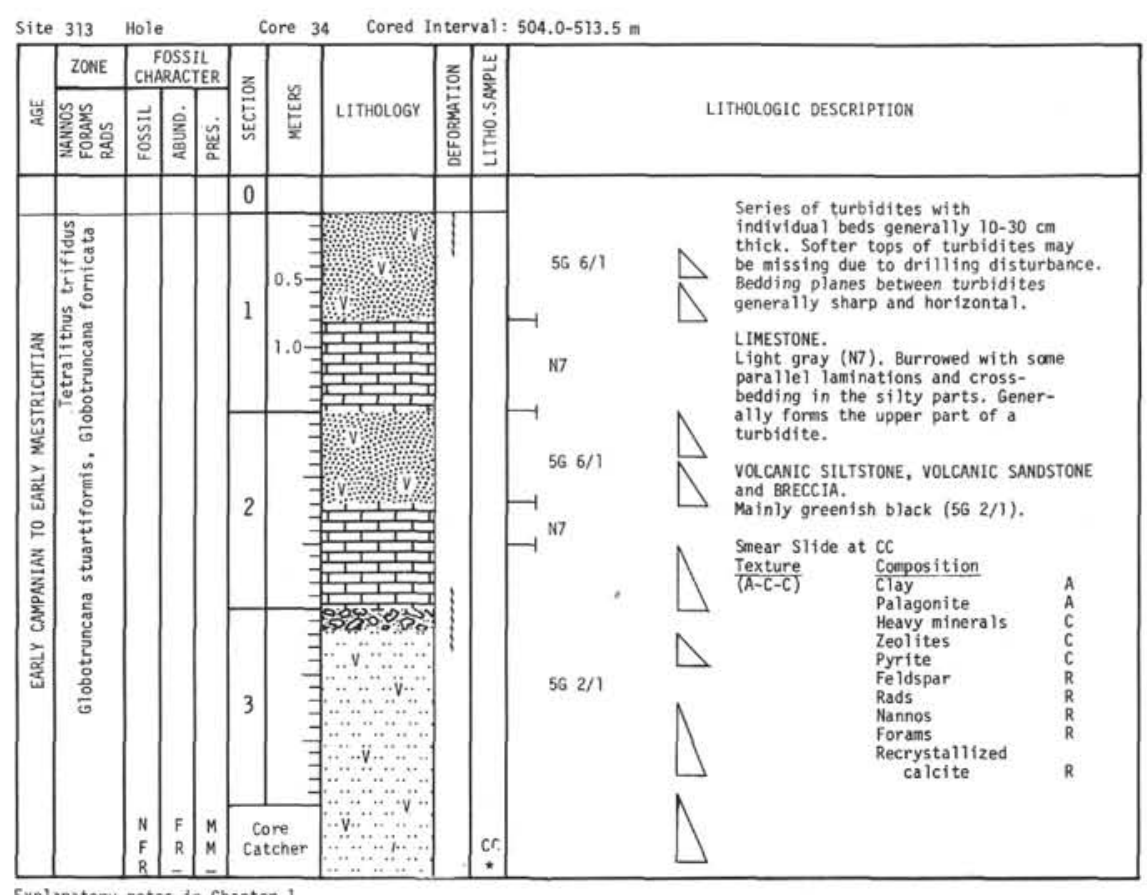



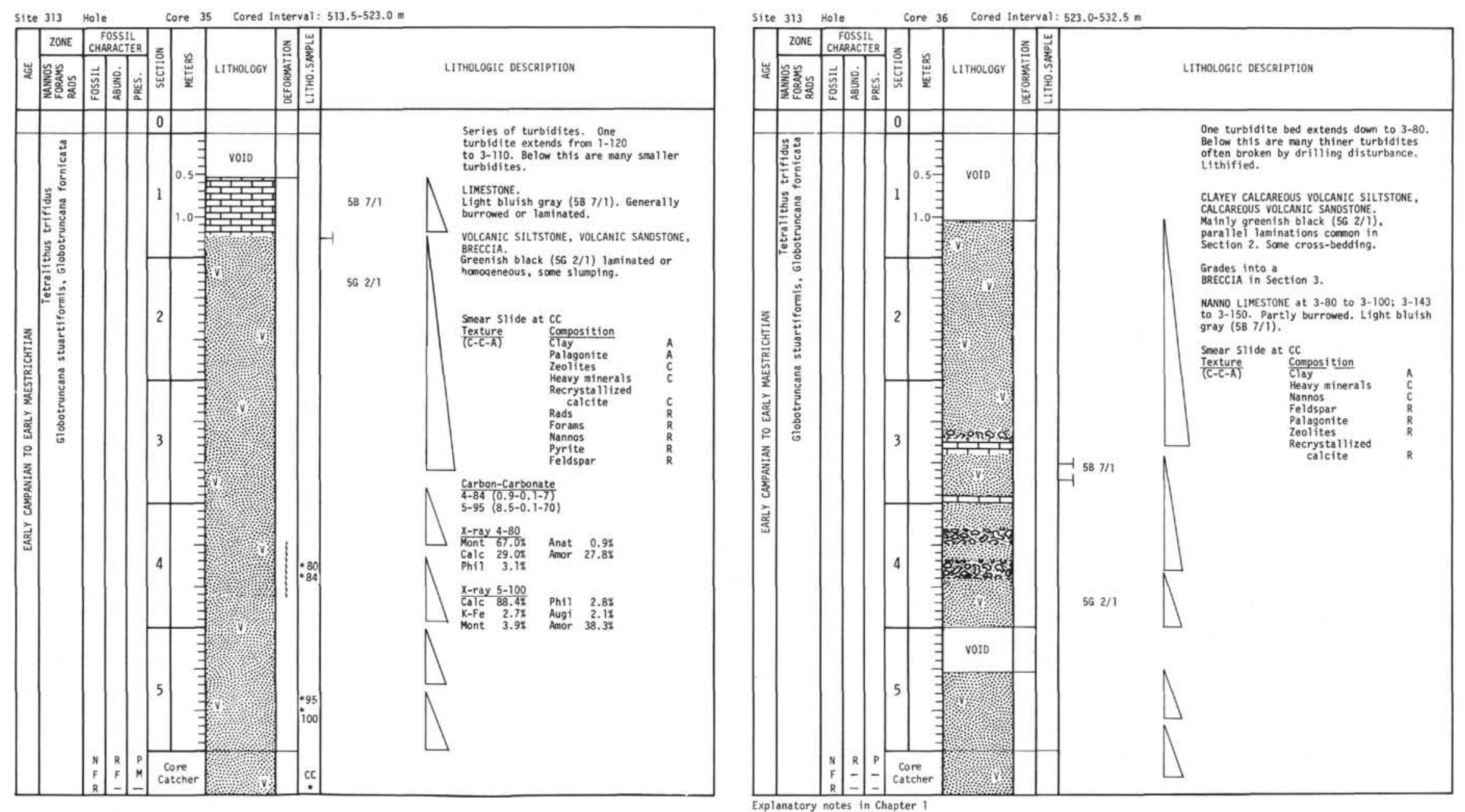


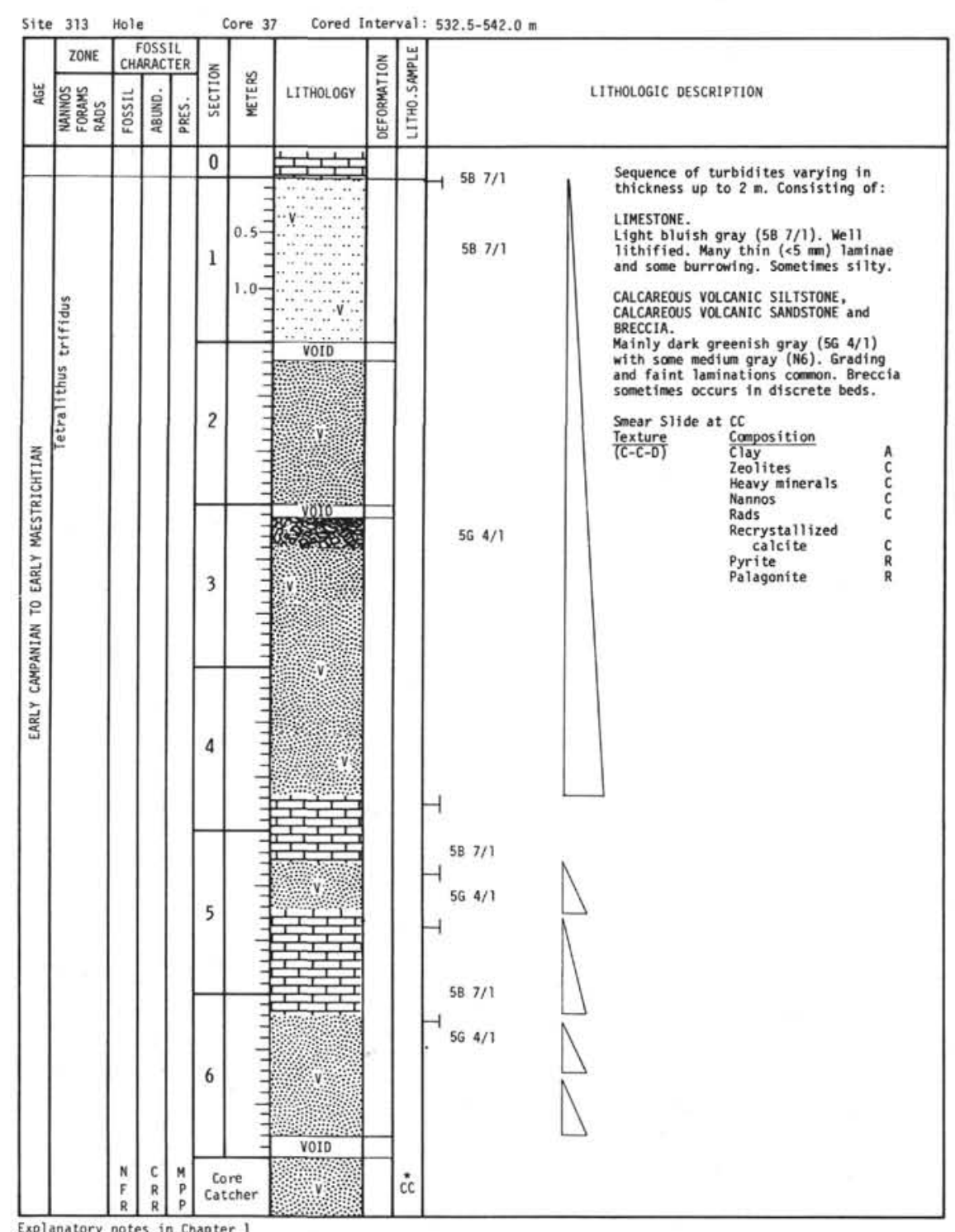

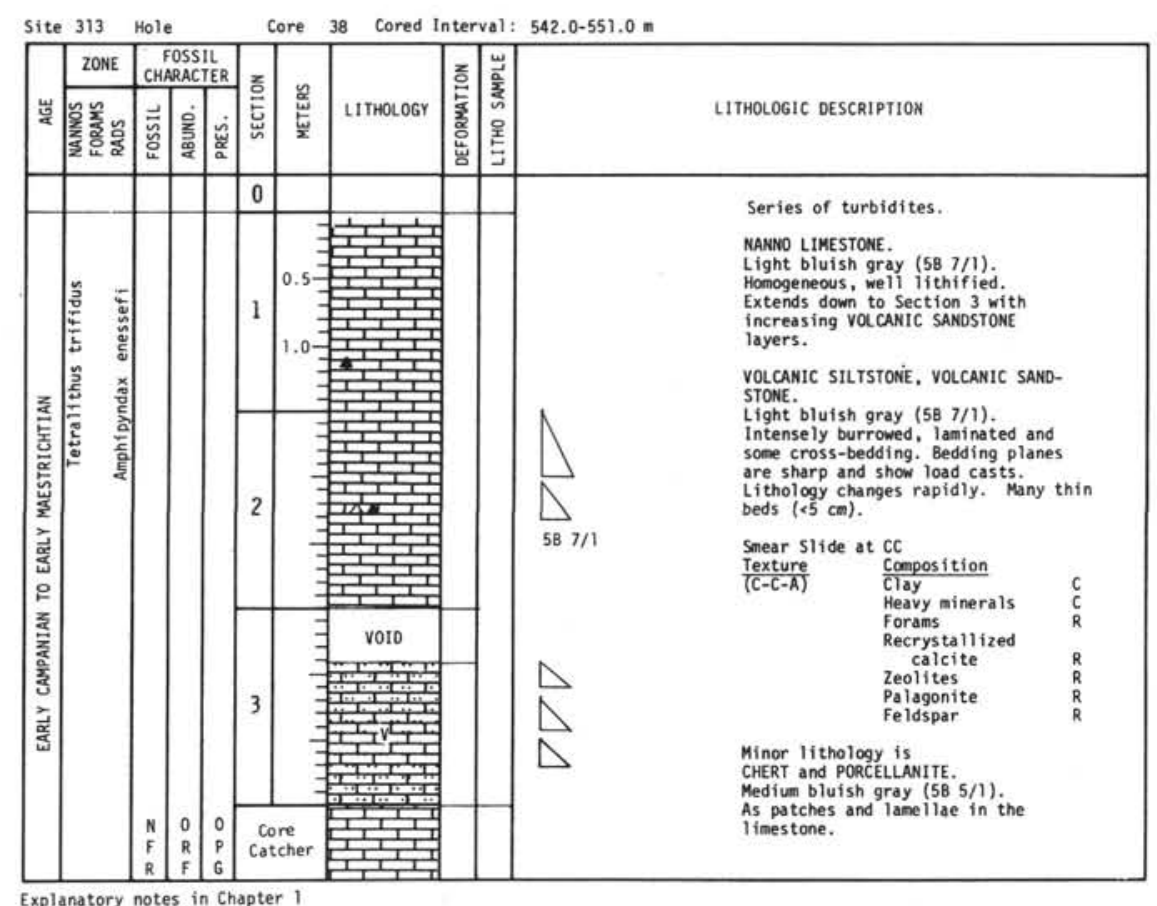




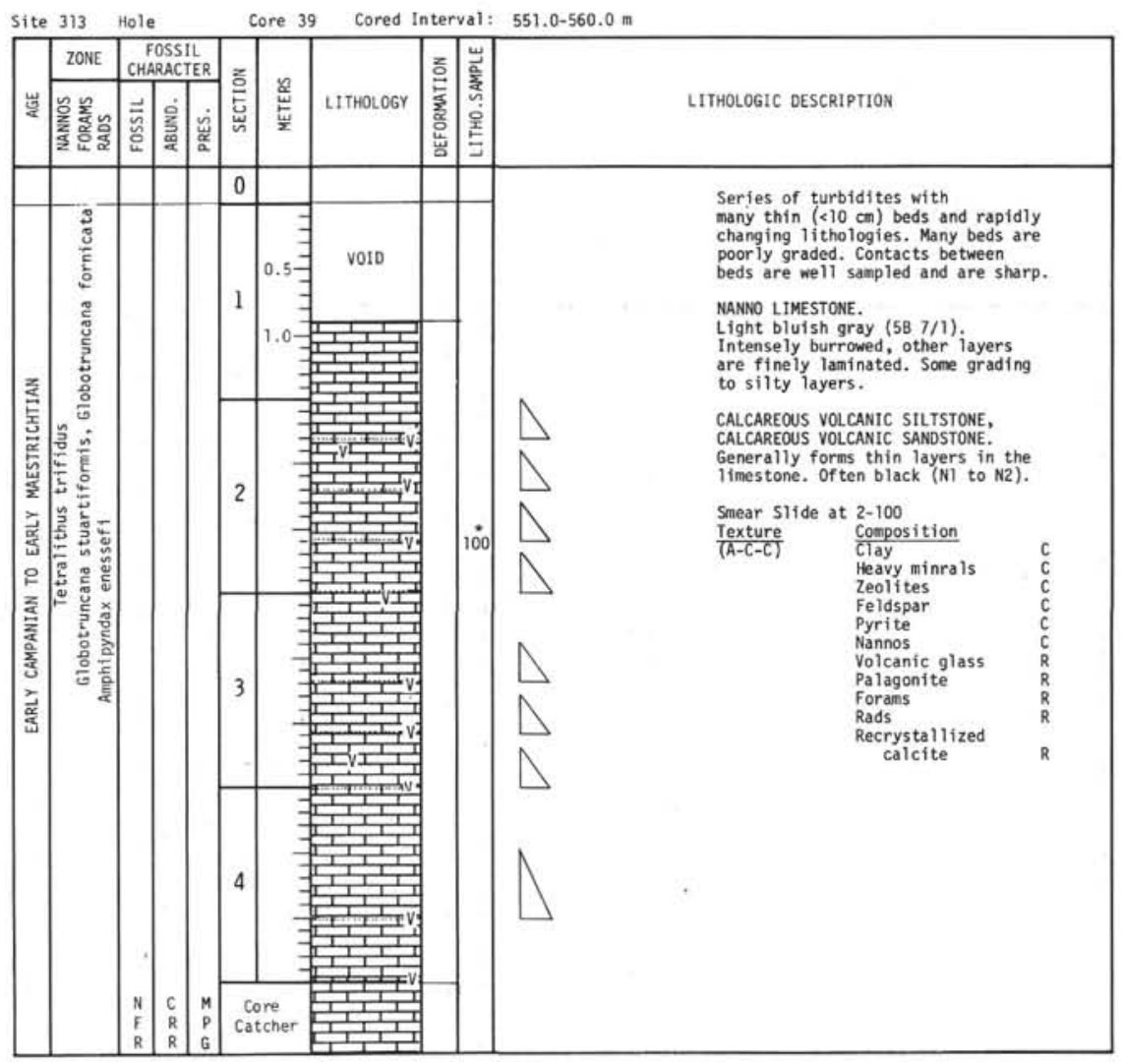

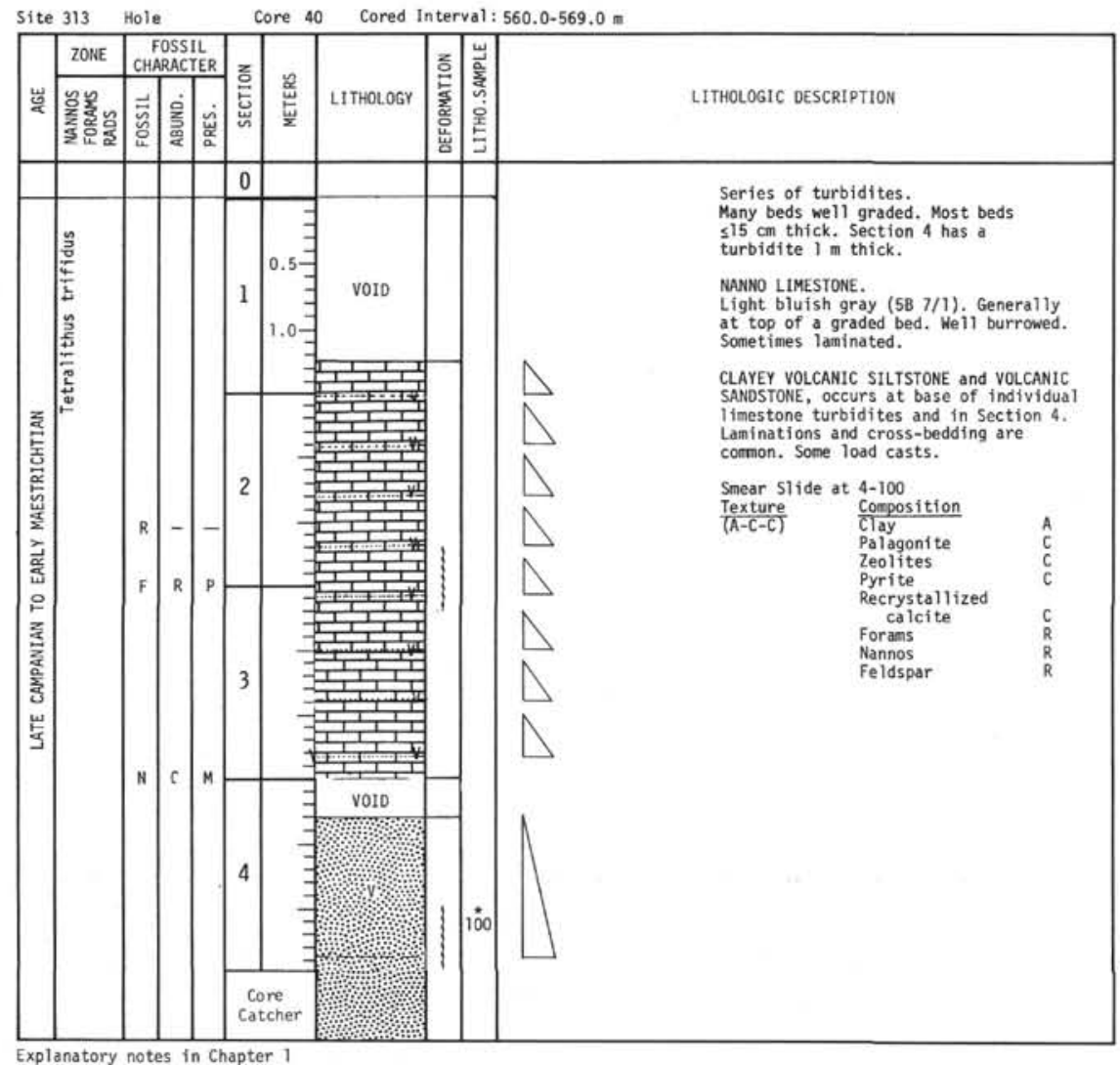




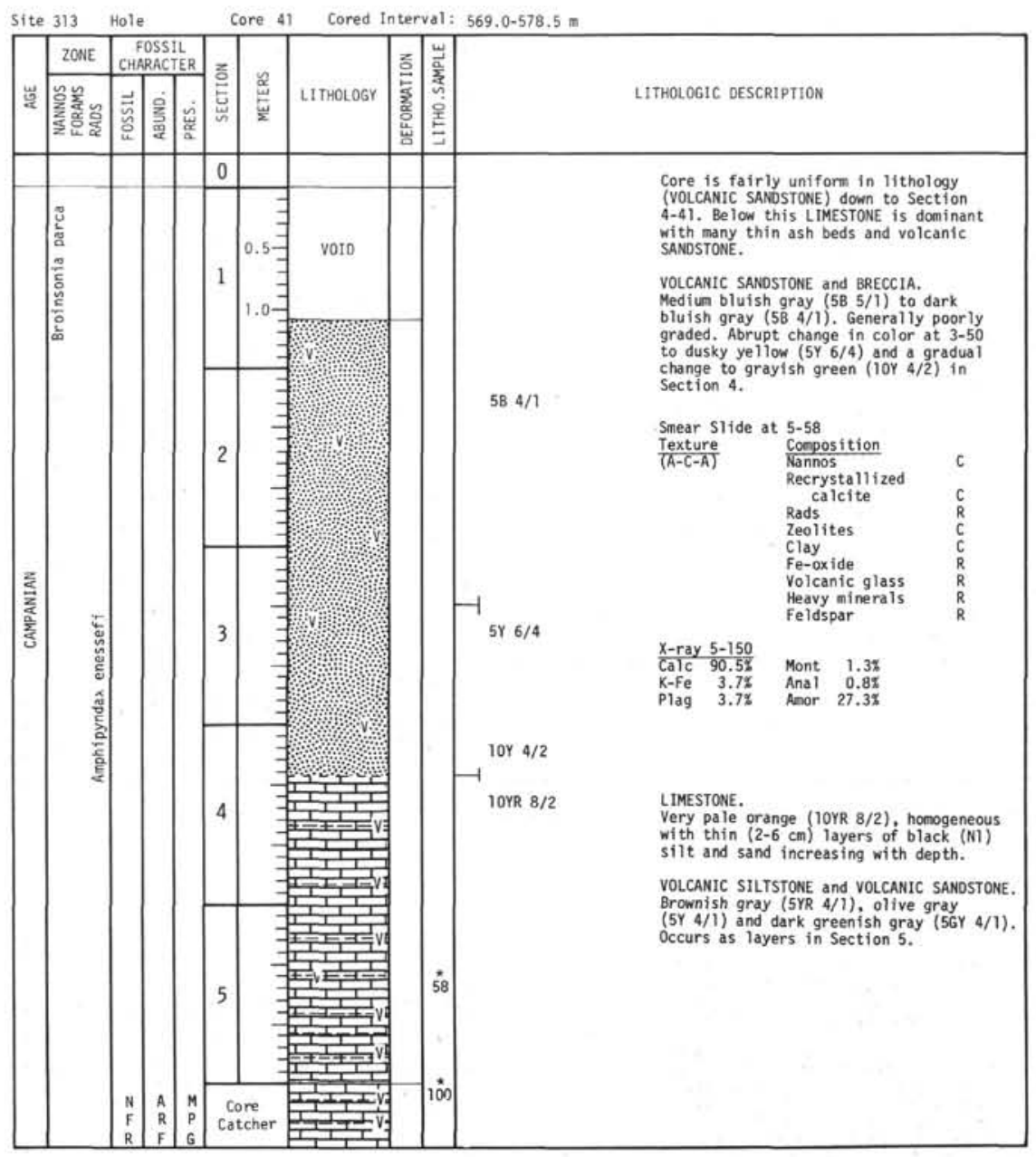

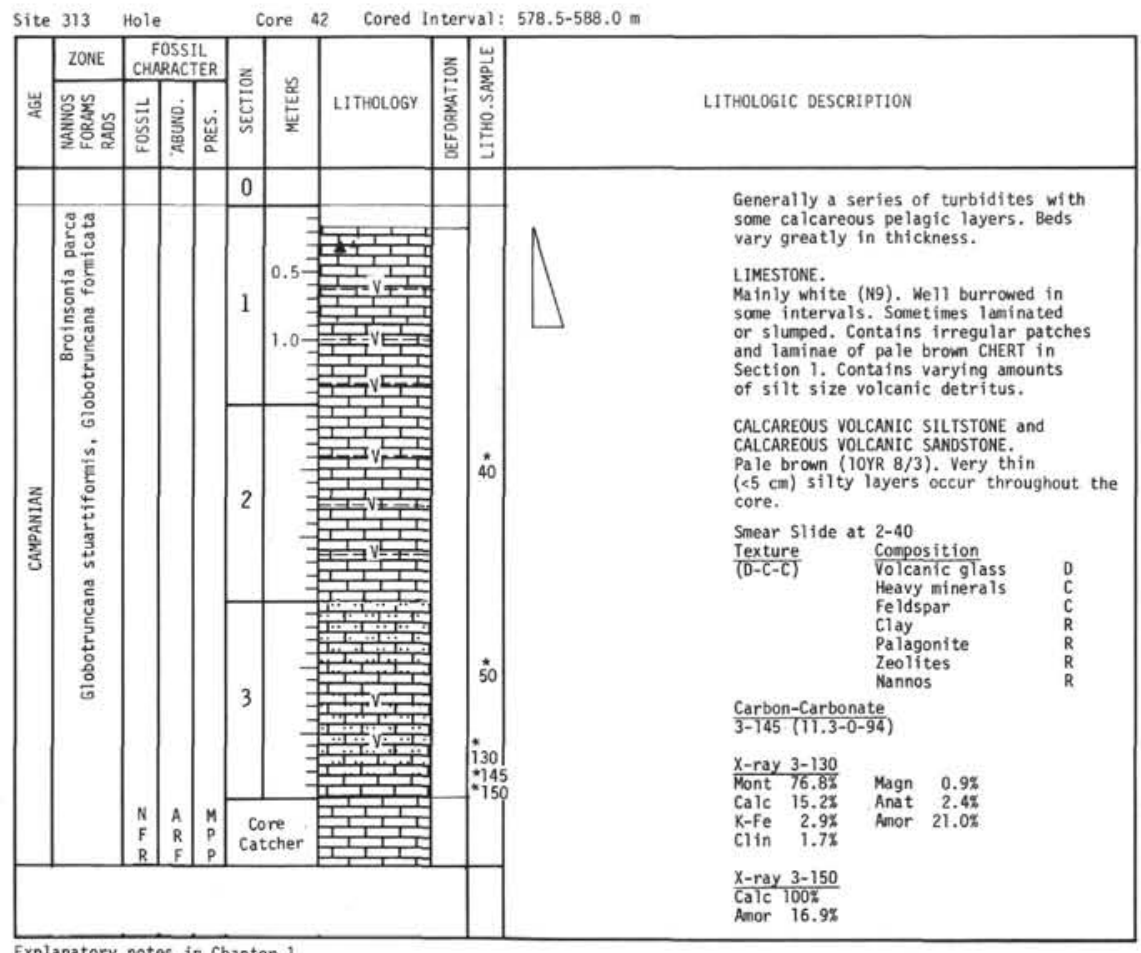




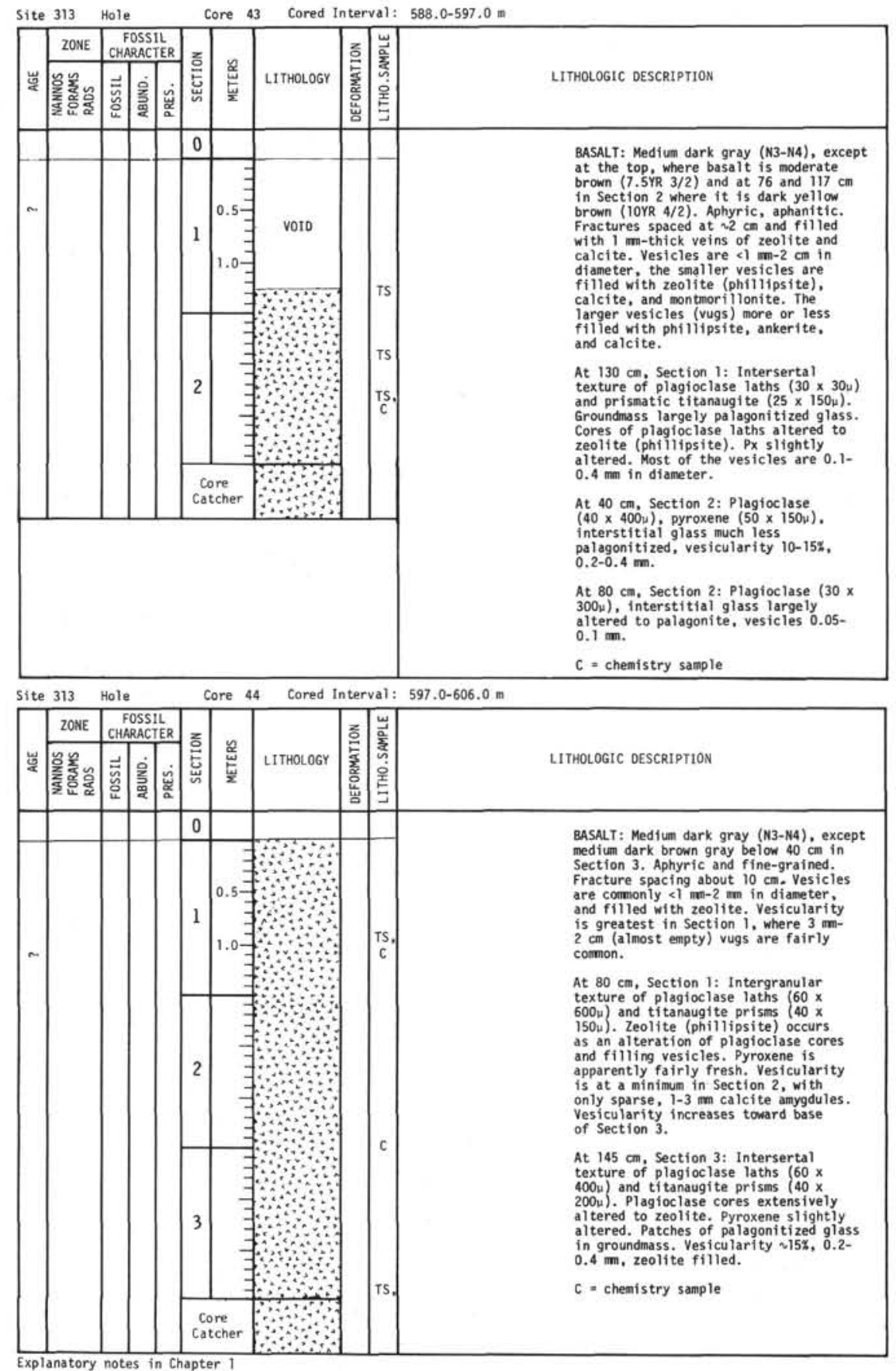


CORE $313-1$

- = GRAPE WET-BULK DENSITY, g/cc

๑ Syringe porosity, \%

COMPRESSIONAL SOUND VELOCITY

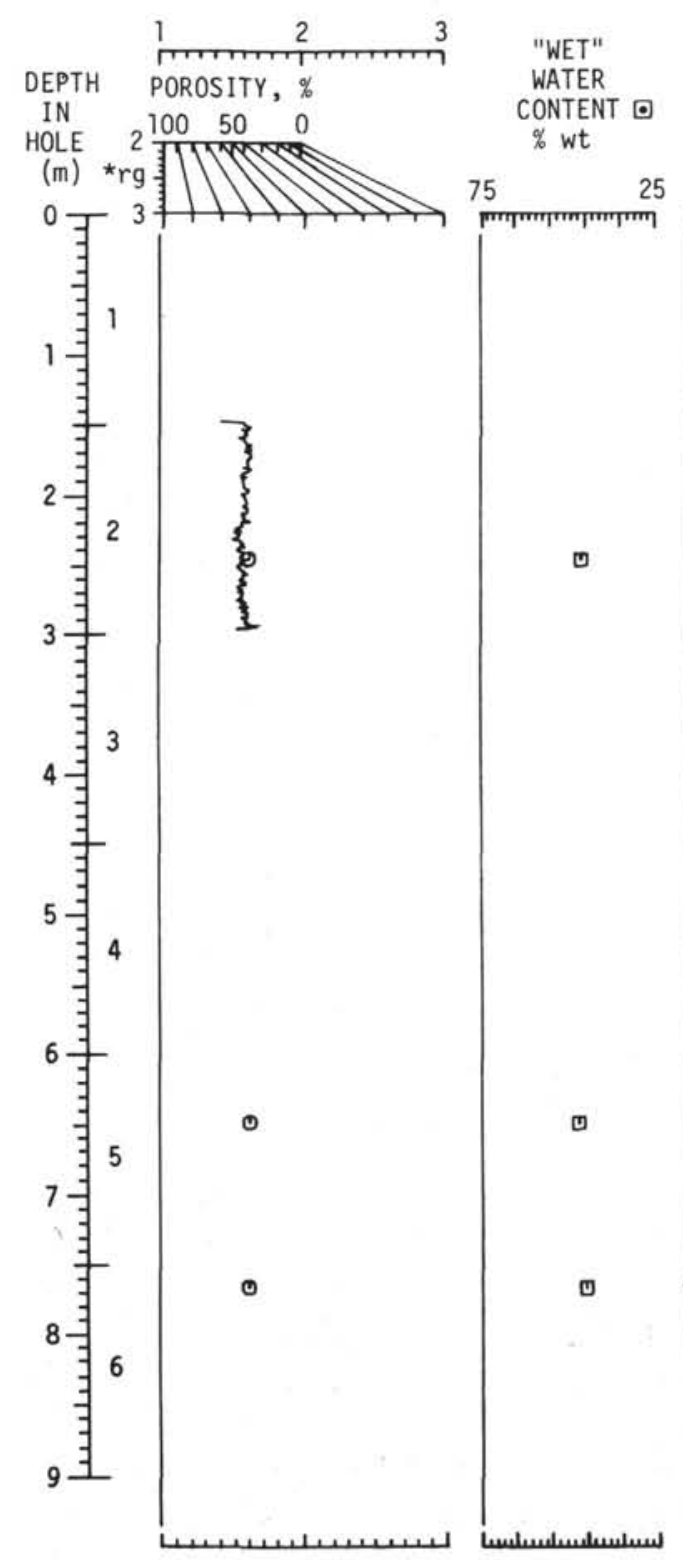

$\sigma$ = Perpendicular To Bedding

$\Delta=$ Parallel To Bedding

$\mathrm{km} / \mathrm{sec}$

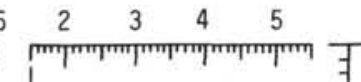

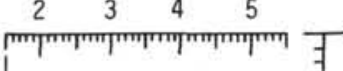

CORE $313-2$

- $=$ GRAPE WET-BULK DENSITY, $g / c c$

- Syringe porosity, \% COMPRESSIONAL SOUND VELOCITY

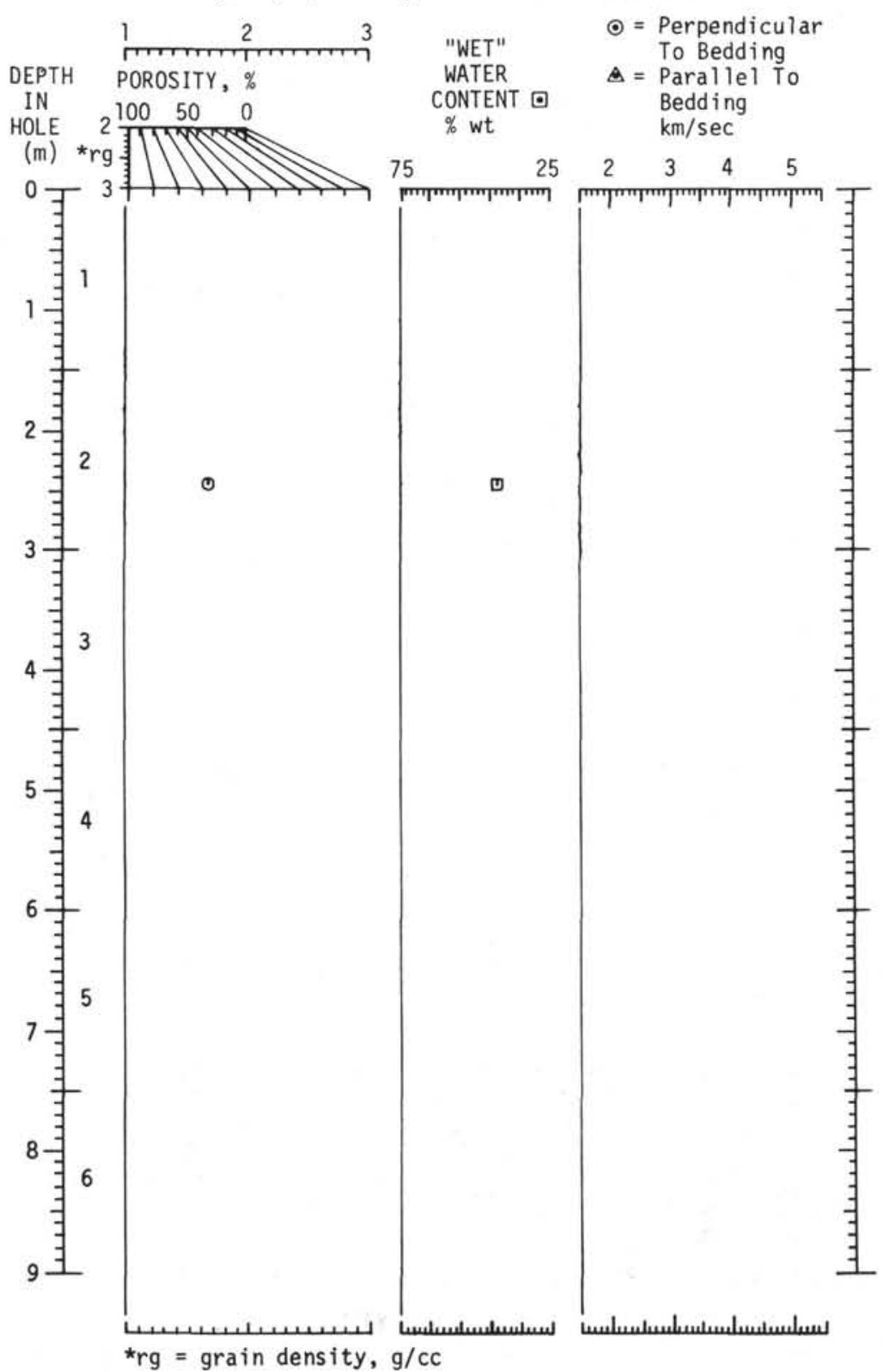


- Syringe porosity, \% COMPRESSIONAL SOUND VELOCITY

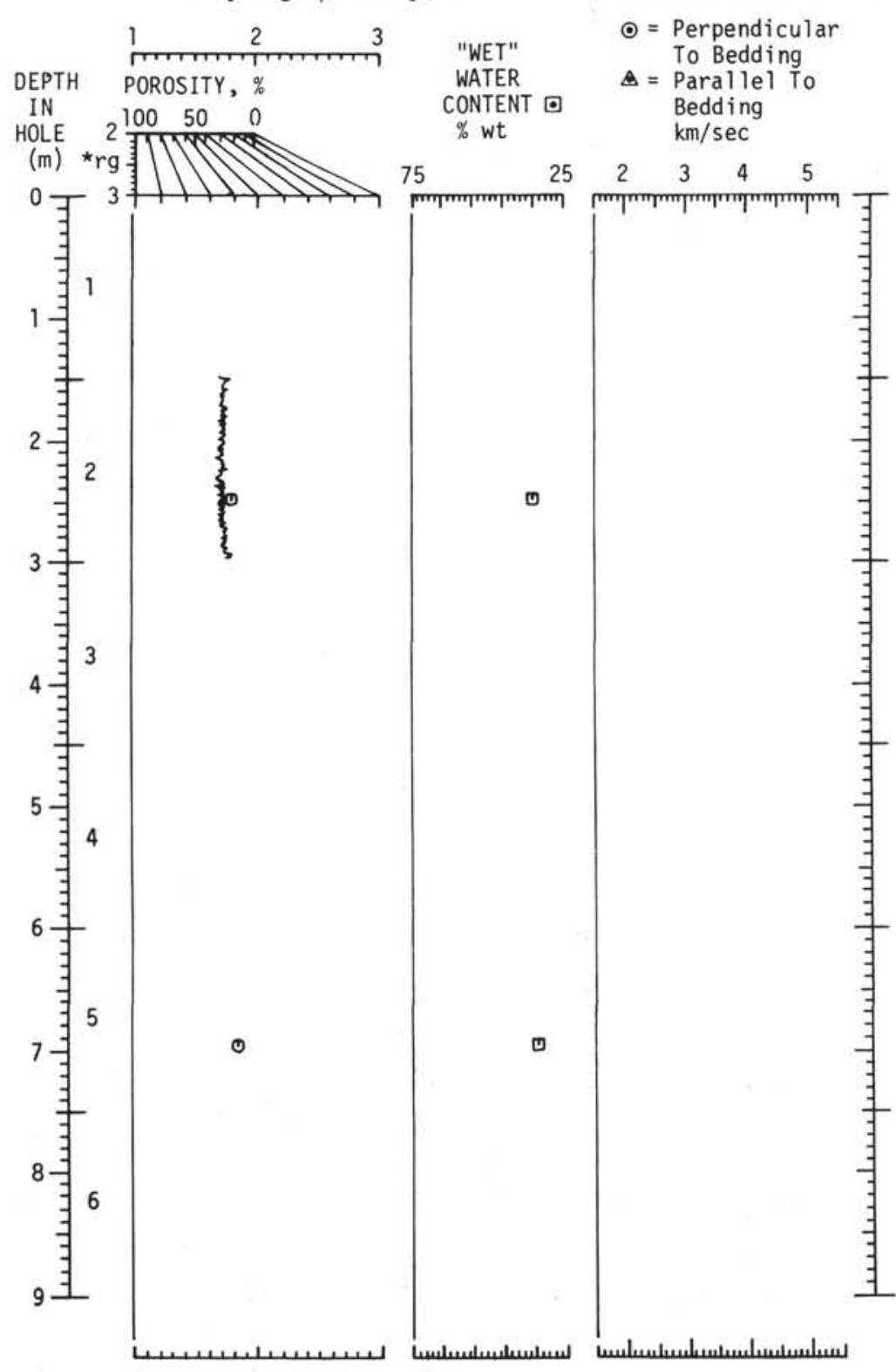

${ }^{*}$ rg $=$ grain density, $g / c c$
- Syringe porosity, \% COMPRESSIONAL SOUND VELOCITY

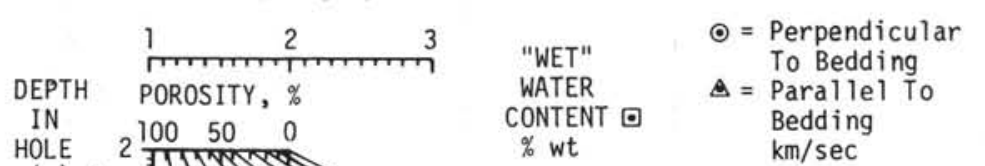

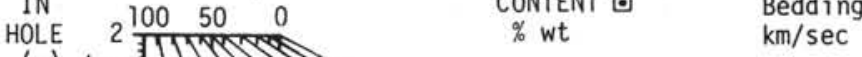

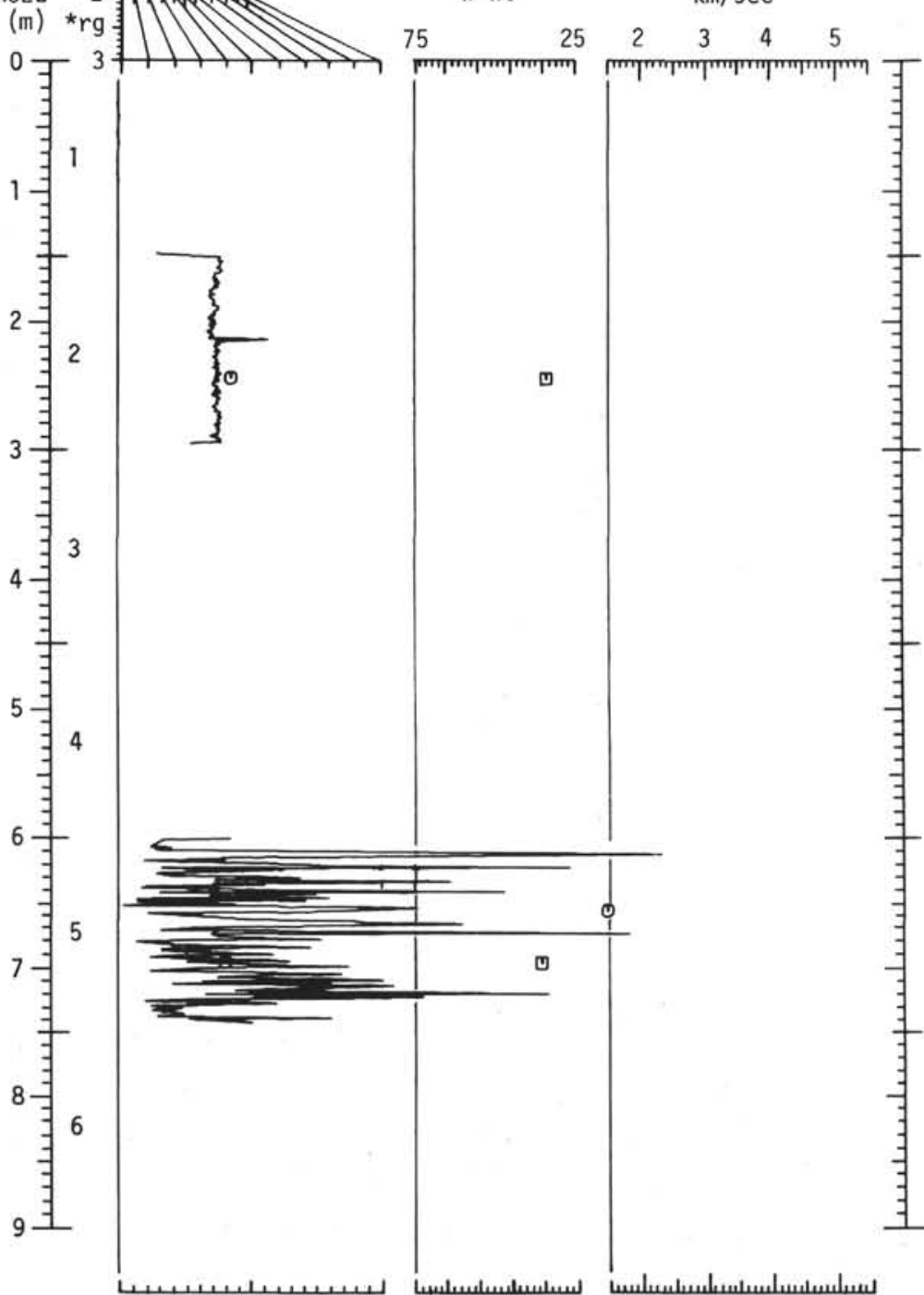

${ }^{*}$ rg $=$ grain density, $g / c c$ 
CORE $313-5$

- $=$ GRAPE WET-BULK DENSITY, g/cc .

- Syringe porosity, \% COMPRESSIONAL SOUND VELOCITY

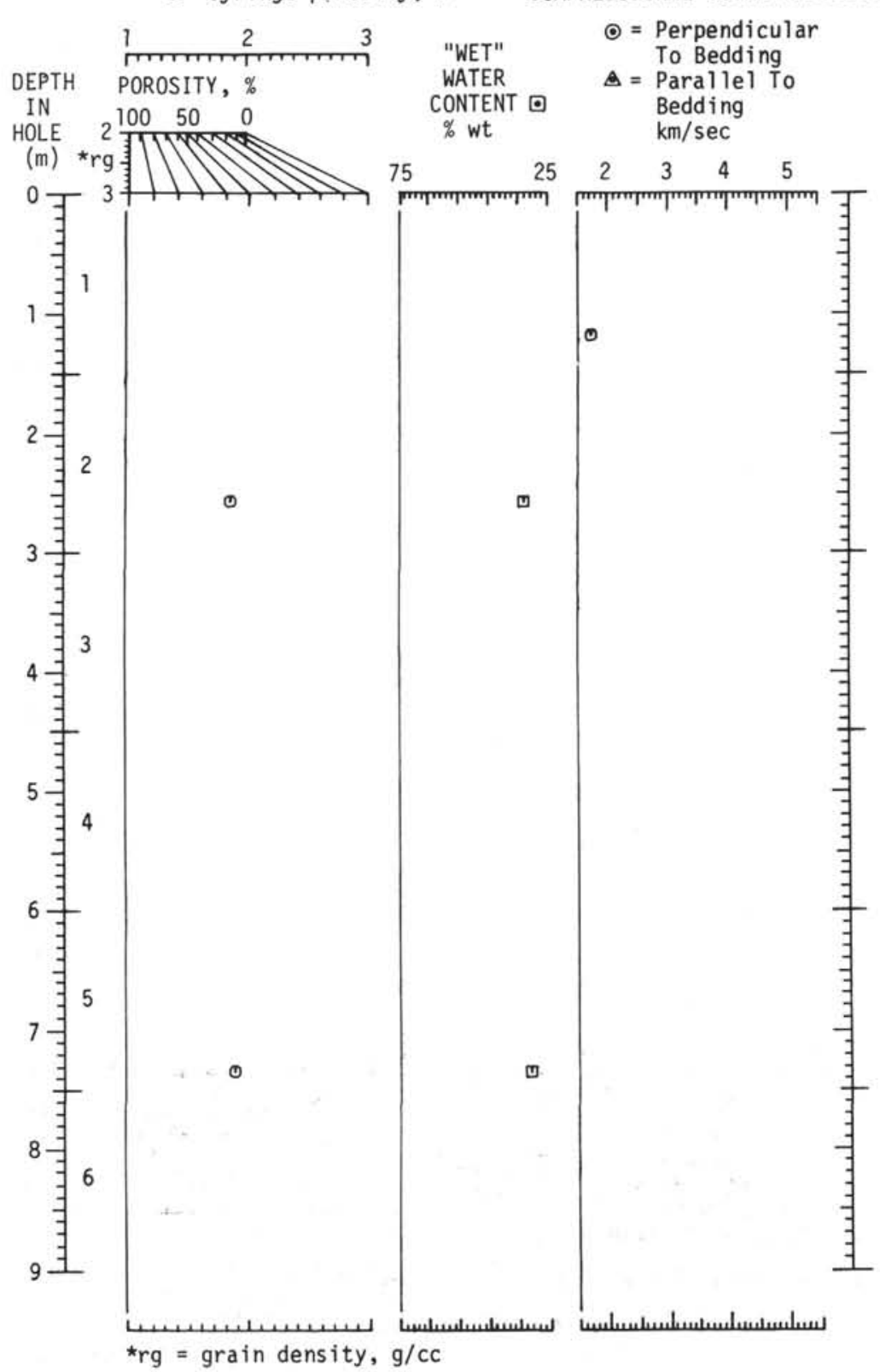

CORE $313-7$

- = GRAPE WET-BULK DENSITY, g/cC

- Syringe porosity, $\%$ COMPRESSIONAL SOUND VELOCITY

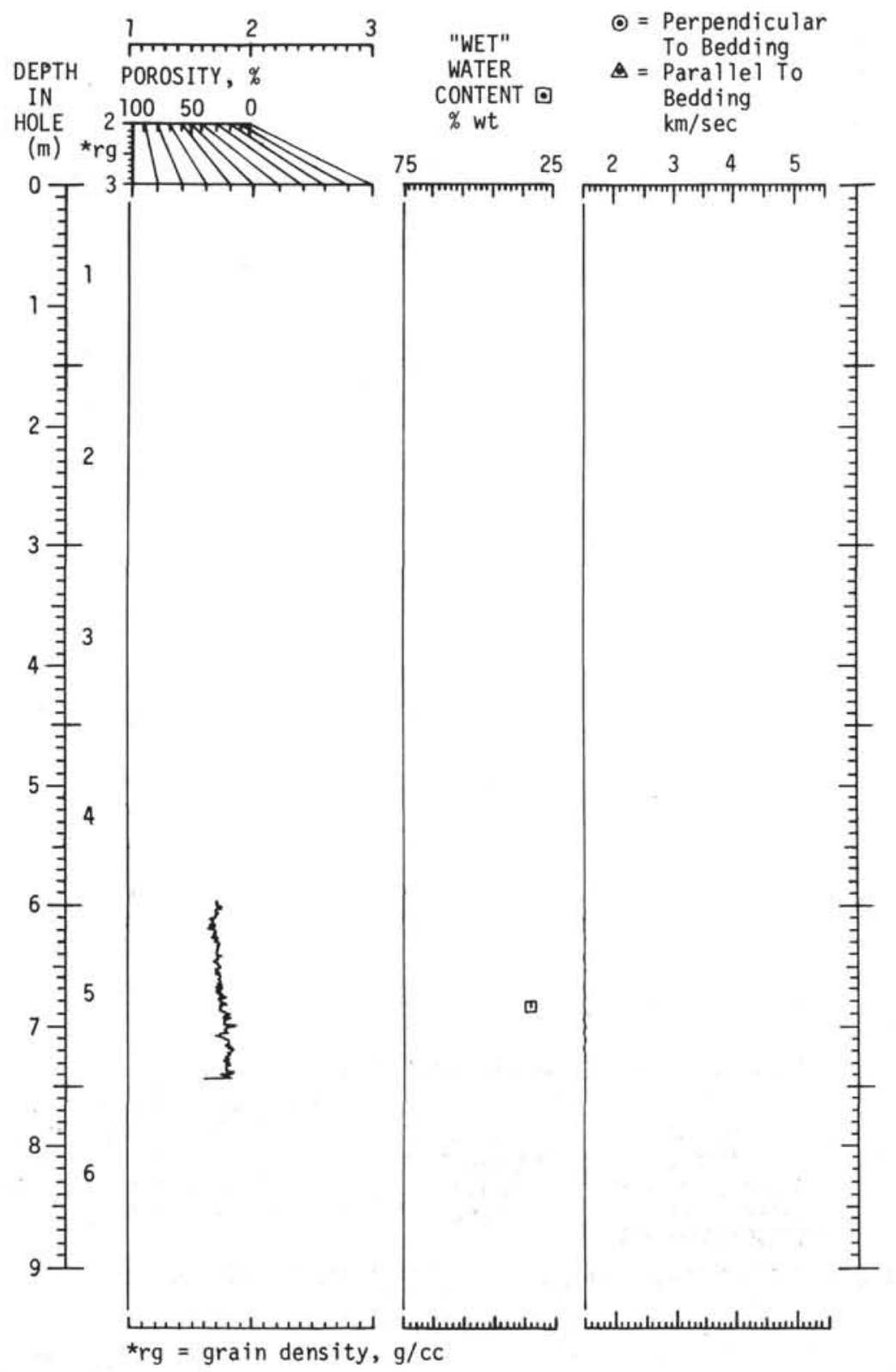


- Syringe porosity, \% COMPRESSIONAL SOUND VELOCITY

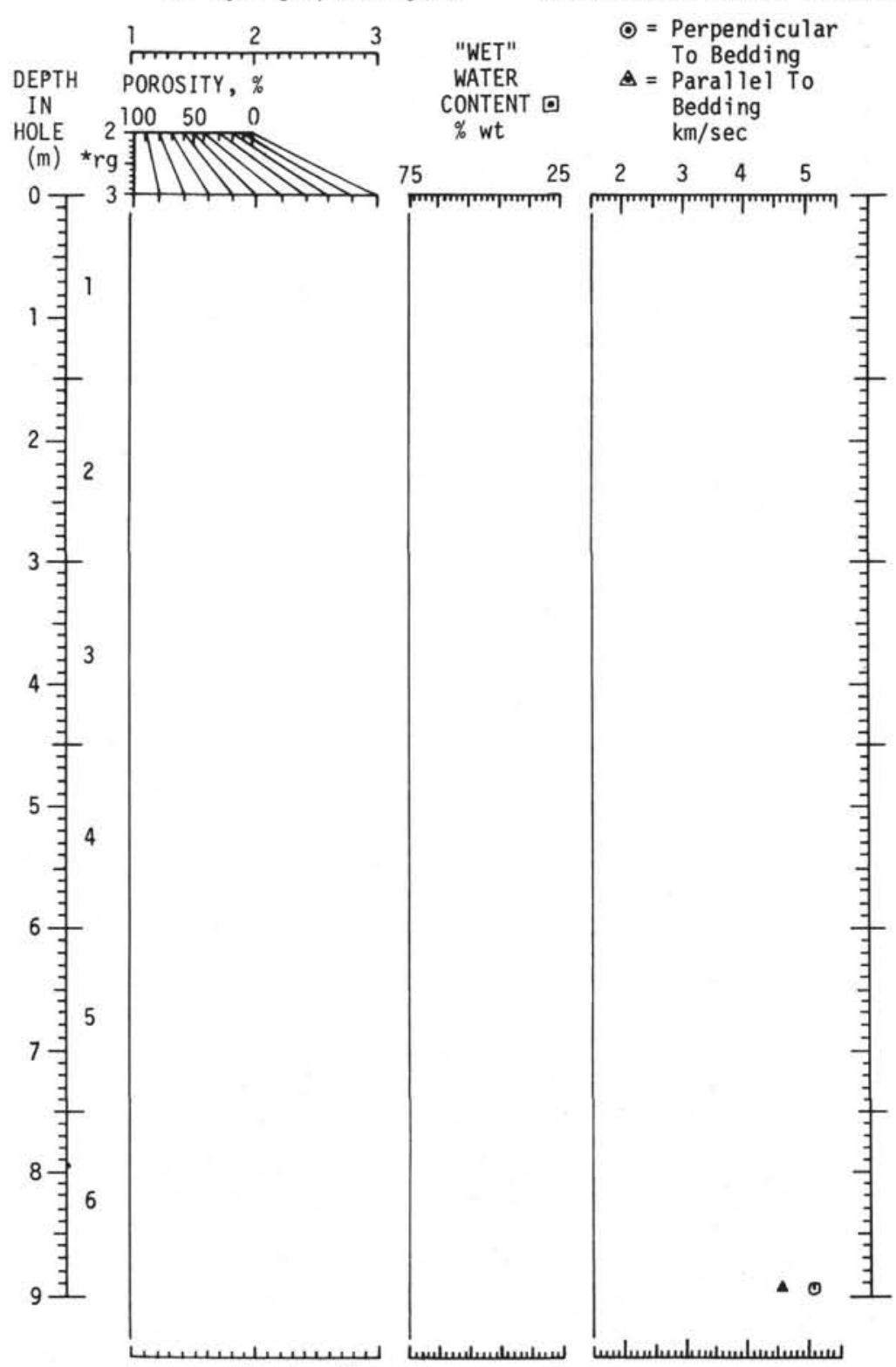

$*^{*}$ g $=$ grain density, g/cc
$=$ GRAPE WET-BULK DENSITY, g/cC

○ Syringe porosity, $\%$ COMPRESSIONAL SOUND VELOCITY

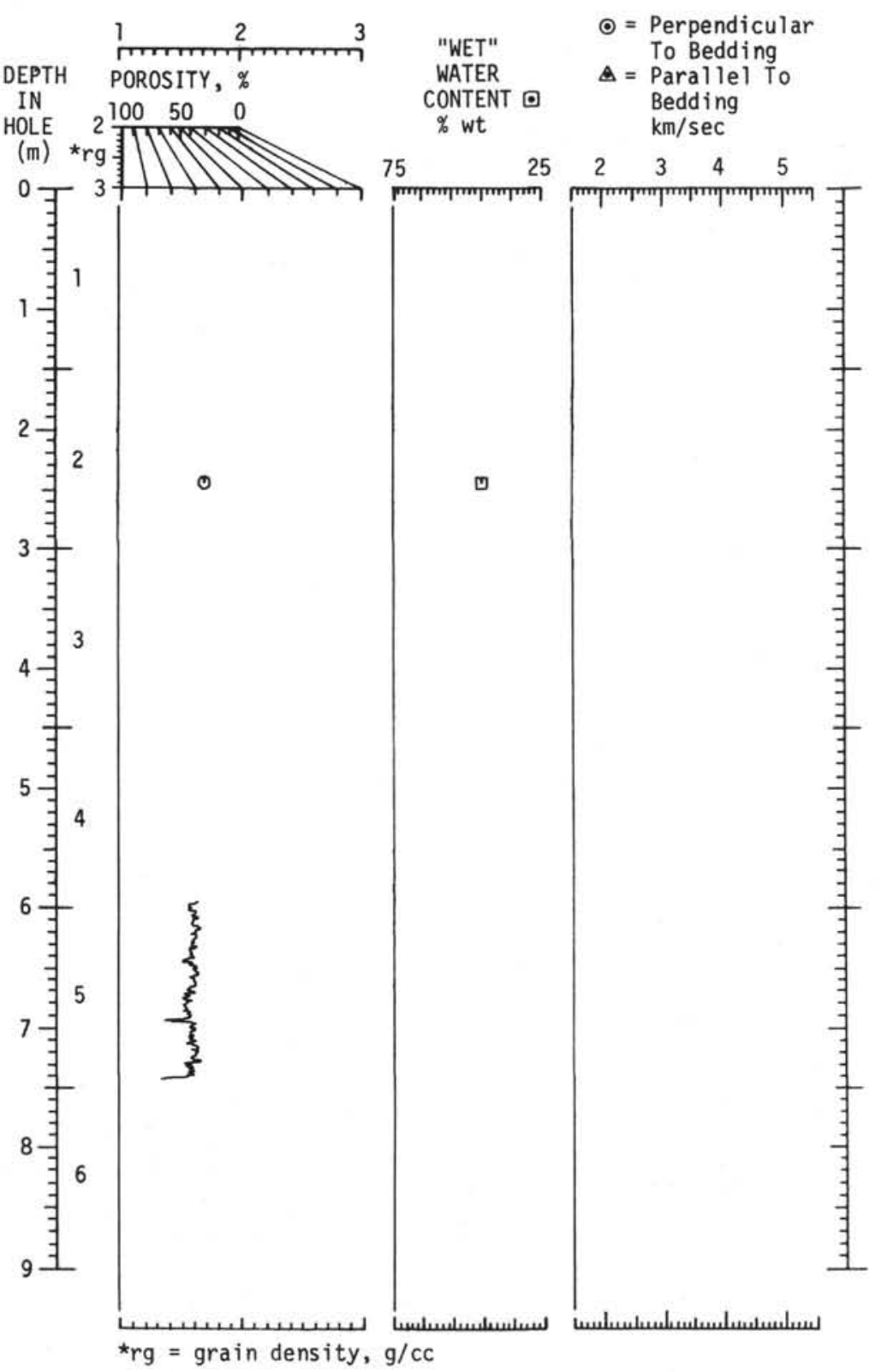


CORE $313-13$

- = GRAPE WET-BULK DENSITY, $\mathrm{g} / \mathrm{cc}$

○ Syringe porosity, \%

COMPRESSIONAL SOUND VELOCITY

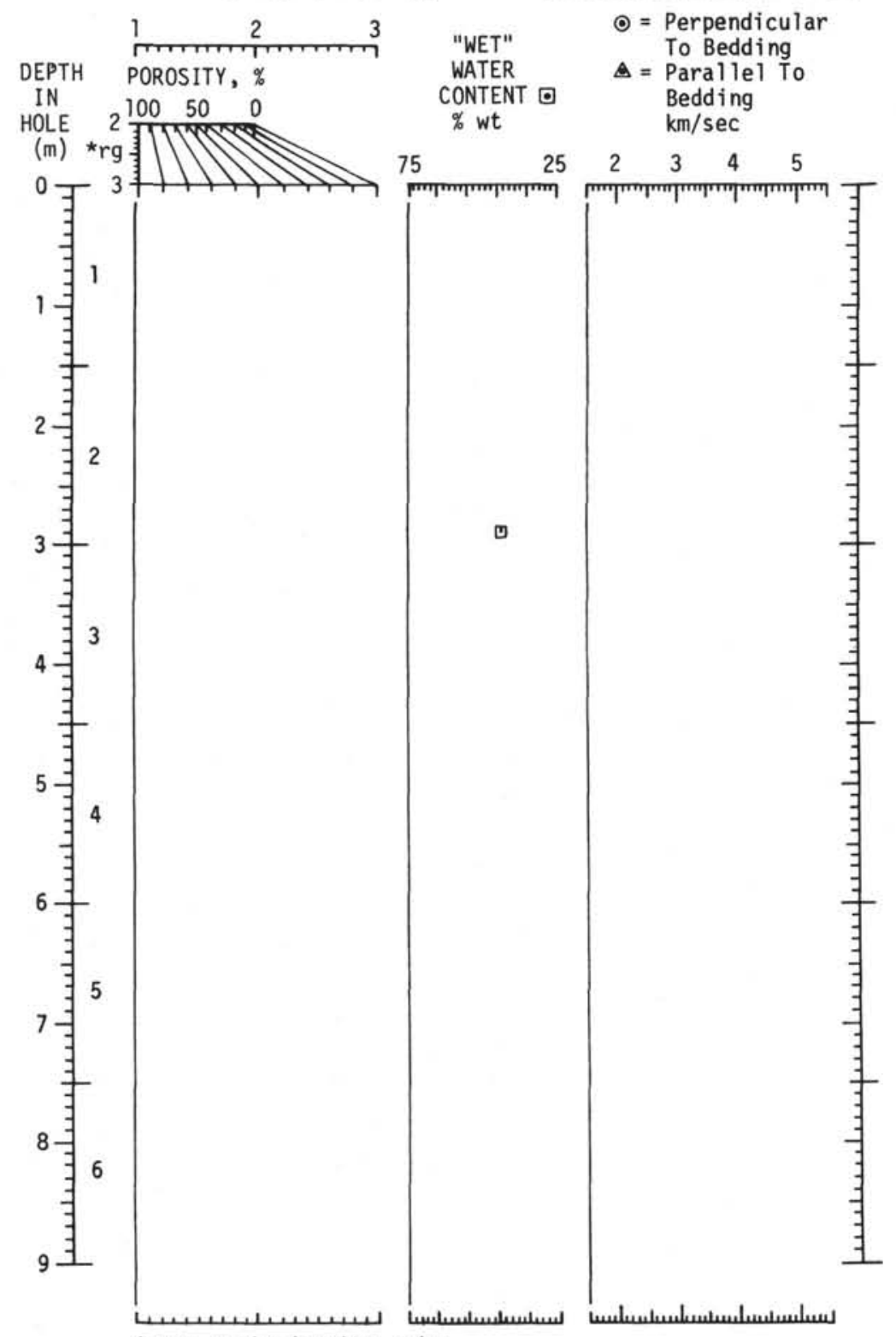

${ }^{*}$ rg $=$ grain density, $g / c c$
CORE $313-15$

- $=$ GRAPE WET-BULK DENSITY, g/cc

○ Syringe porosity, \% COMPRESSIONAL SOUND VELOCITY

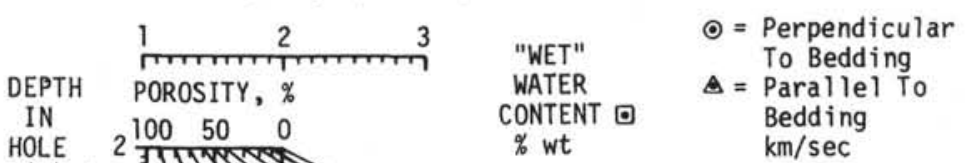

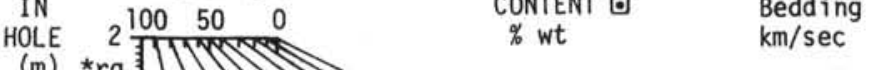

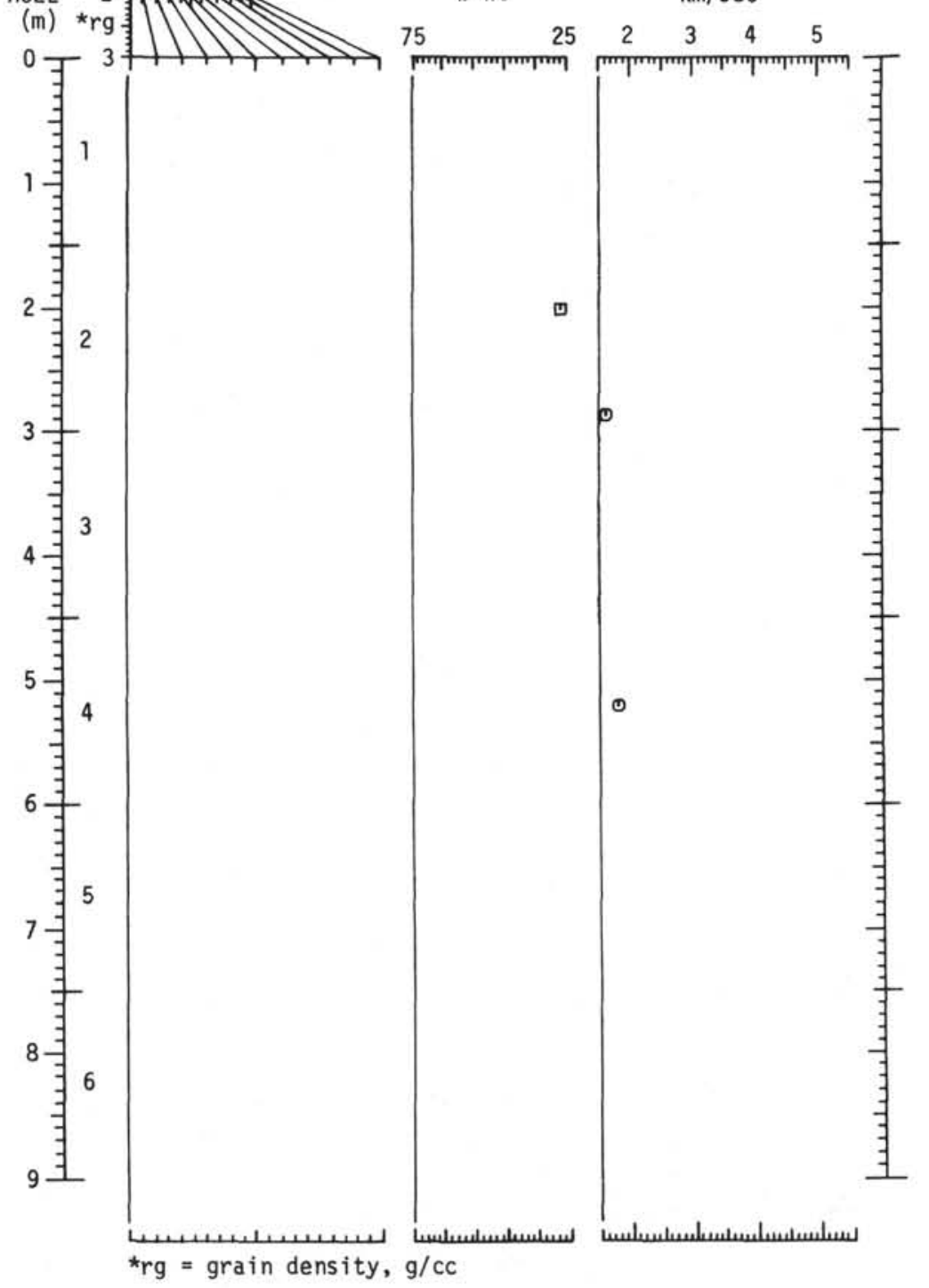


○ Syringe porosity, \% COMPRESSIONAL SOUND VELOCITY
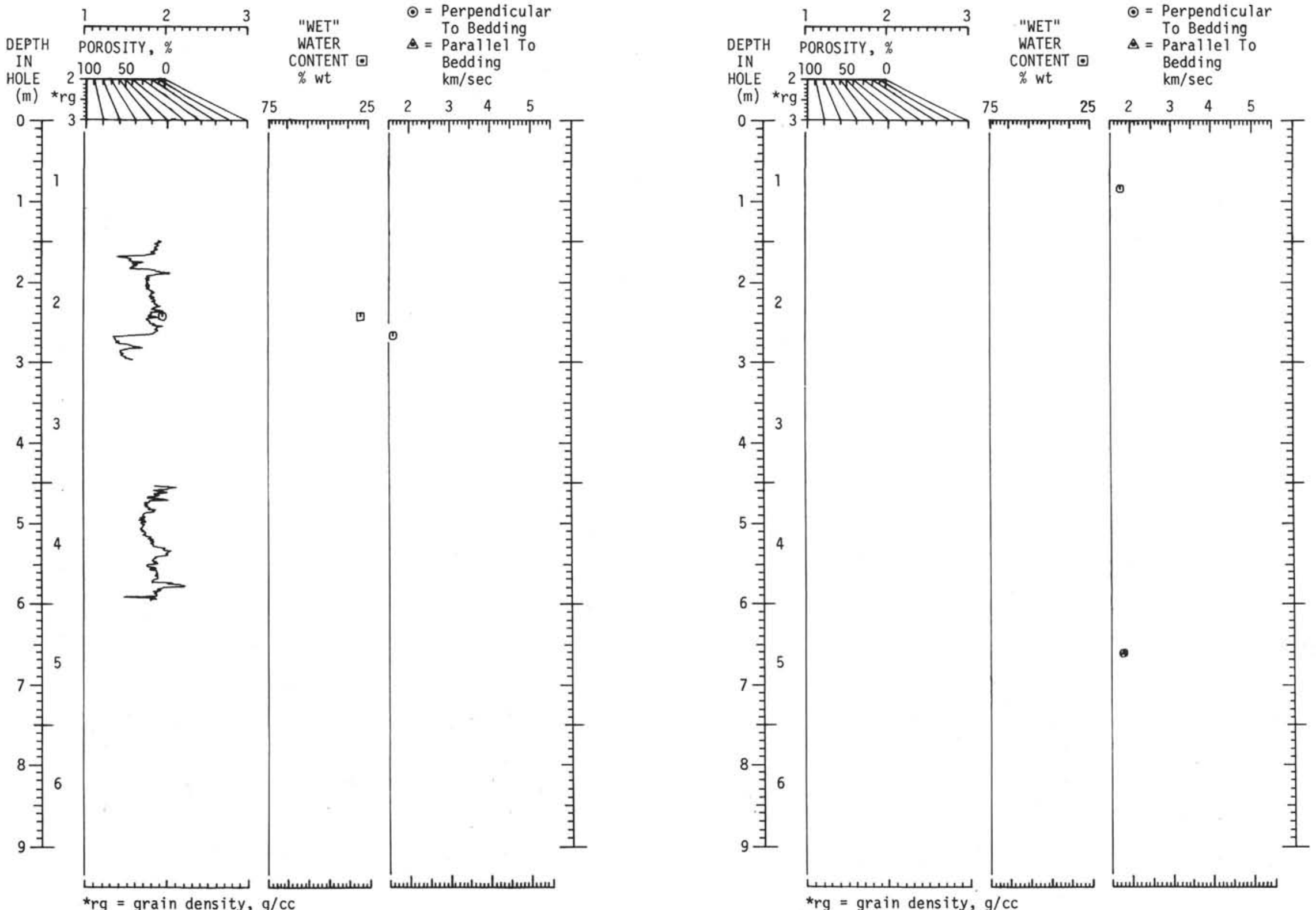
CORE $\quad 313-19$

- $=$ GRAPE WET-BULK DENSITY, $g / c c$

- Syringe porosity, \% COMPRESSIONAL SOUND VELOCITY

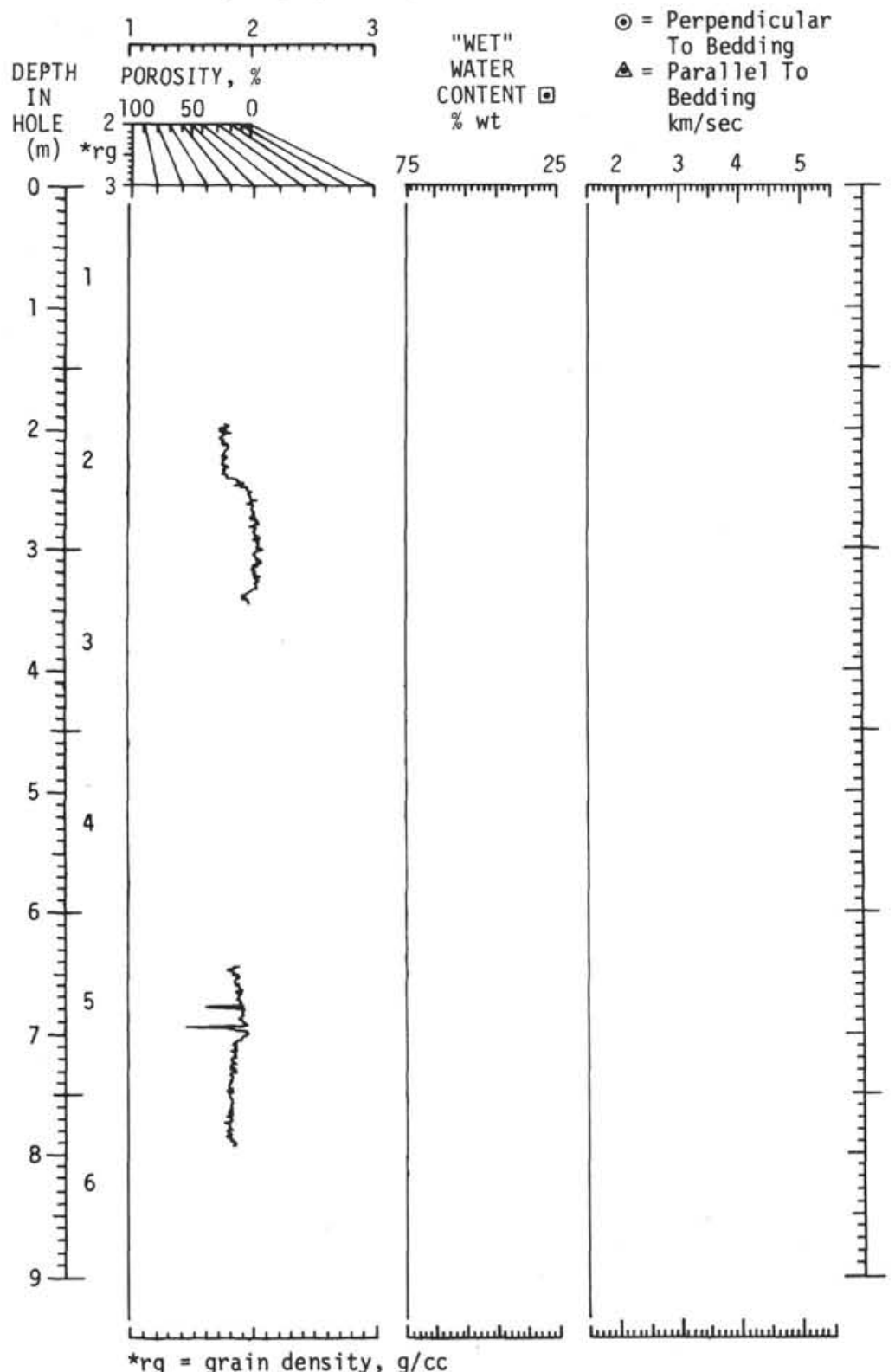

CORE $\quad 313-20$

- = GRAPE WET-BULK DENSITY, g/cc

- Syringe porosity, \% COMPRESSIONAL SOUND VELOCITY

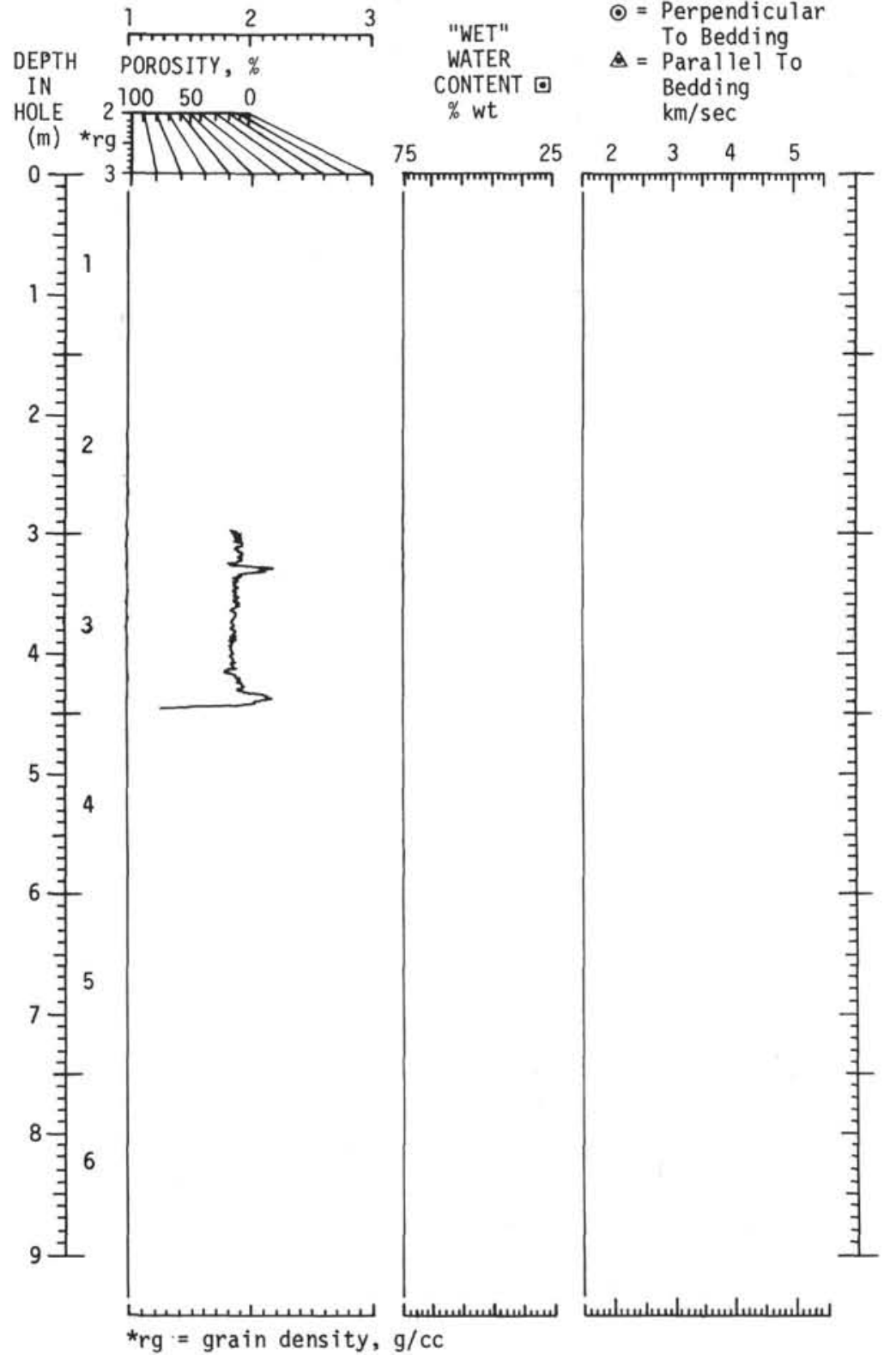


- Syringe porosity, $\%$ COMPRESSIONAL SOUND VELOCITY

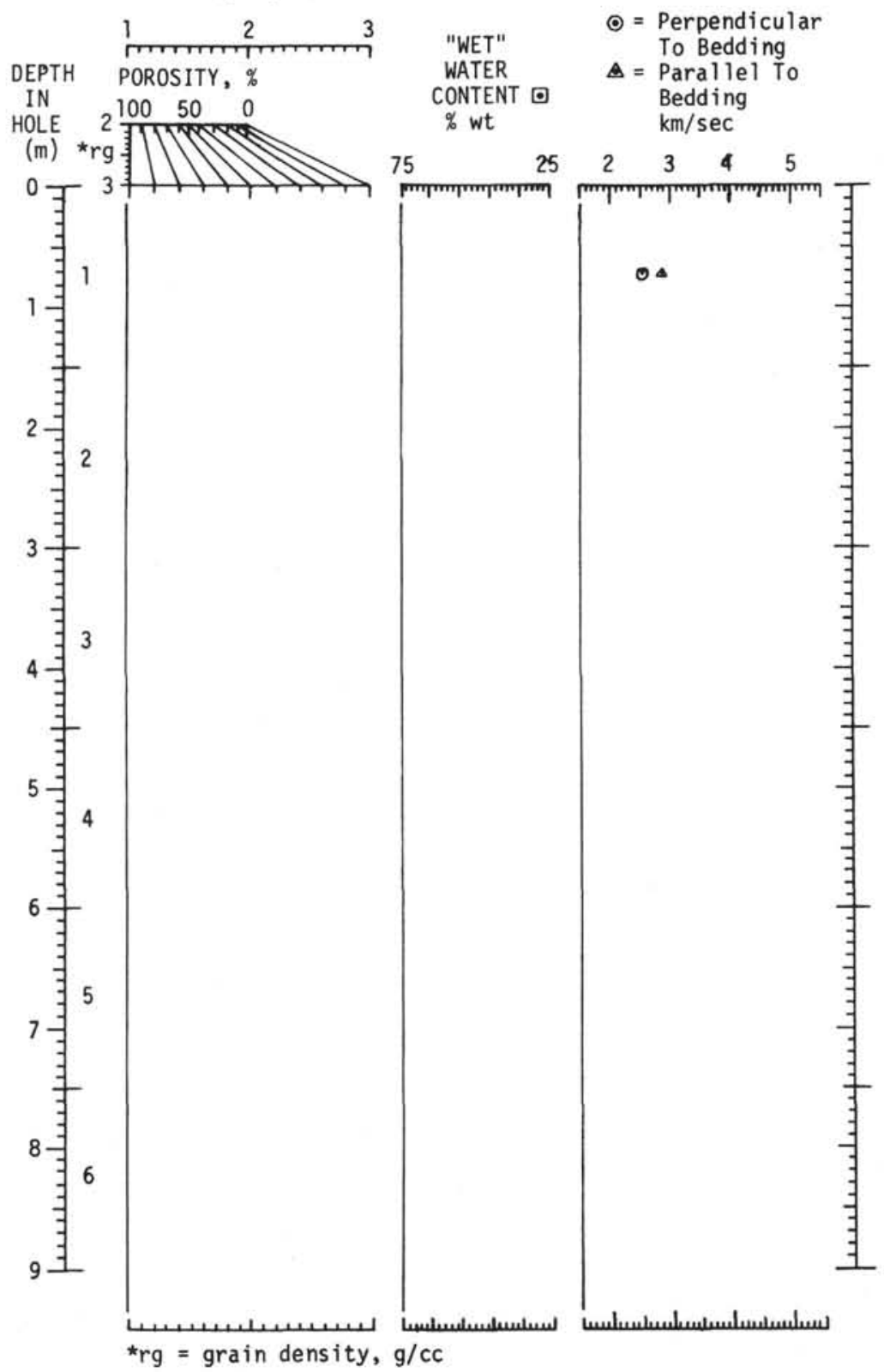

- Syringe porosity, \%

COMPRESSIONAL SOUND VELOCITY
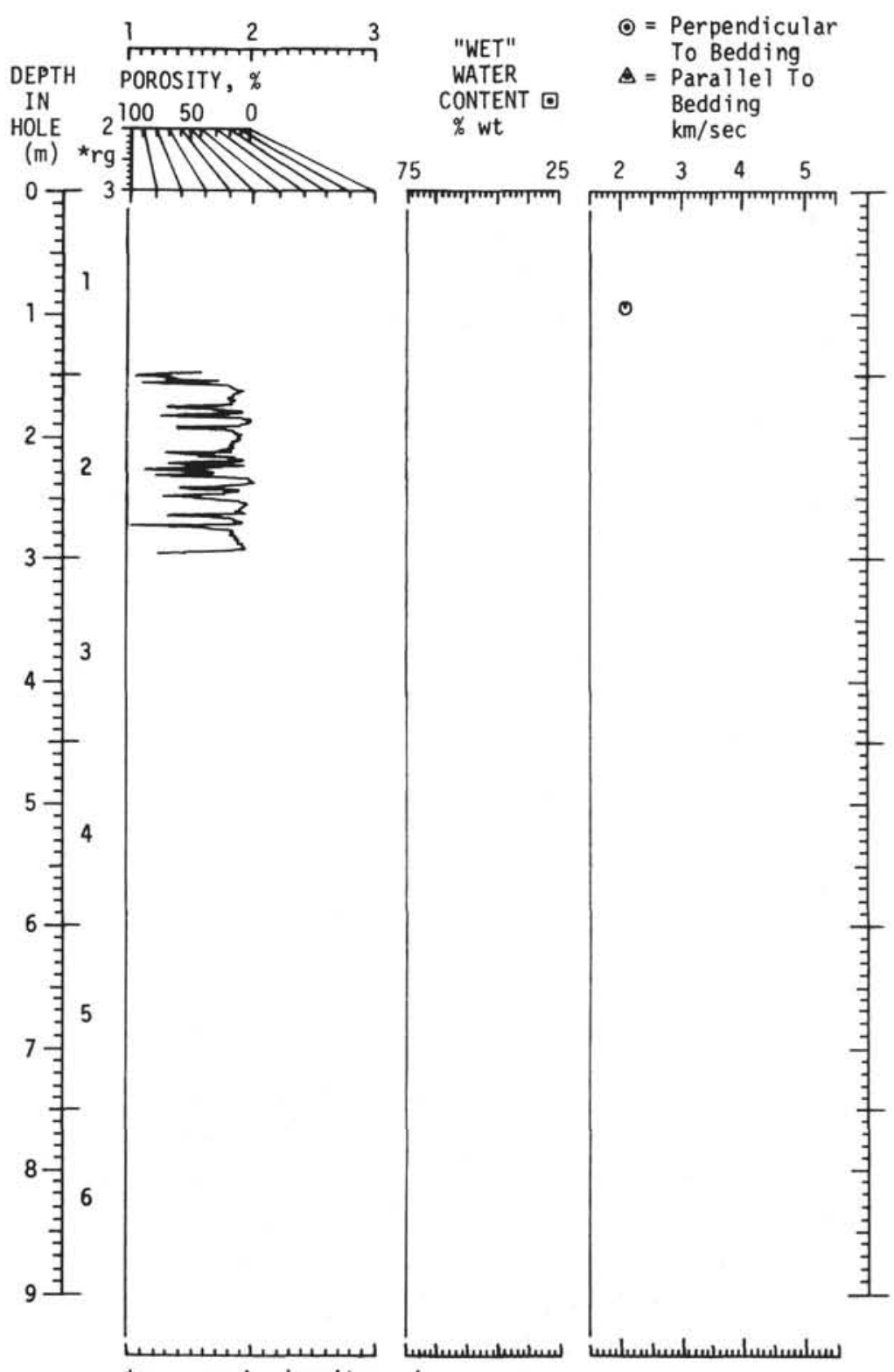

${ }^{*} r g=$ grain density, $g / c c$ 
CORE 313-24

- $=$ GRAPE WET-BULK DENSITY, $g / c c$

- Syringe porosity, \% COMPRESSIONAL SOUND VELOCITY

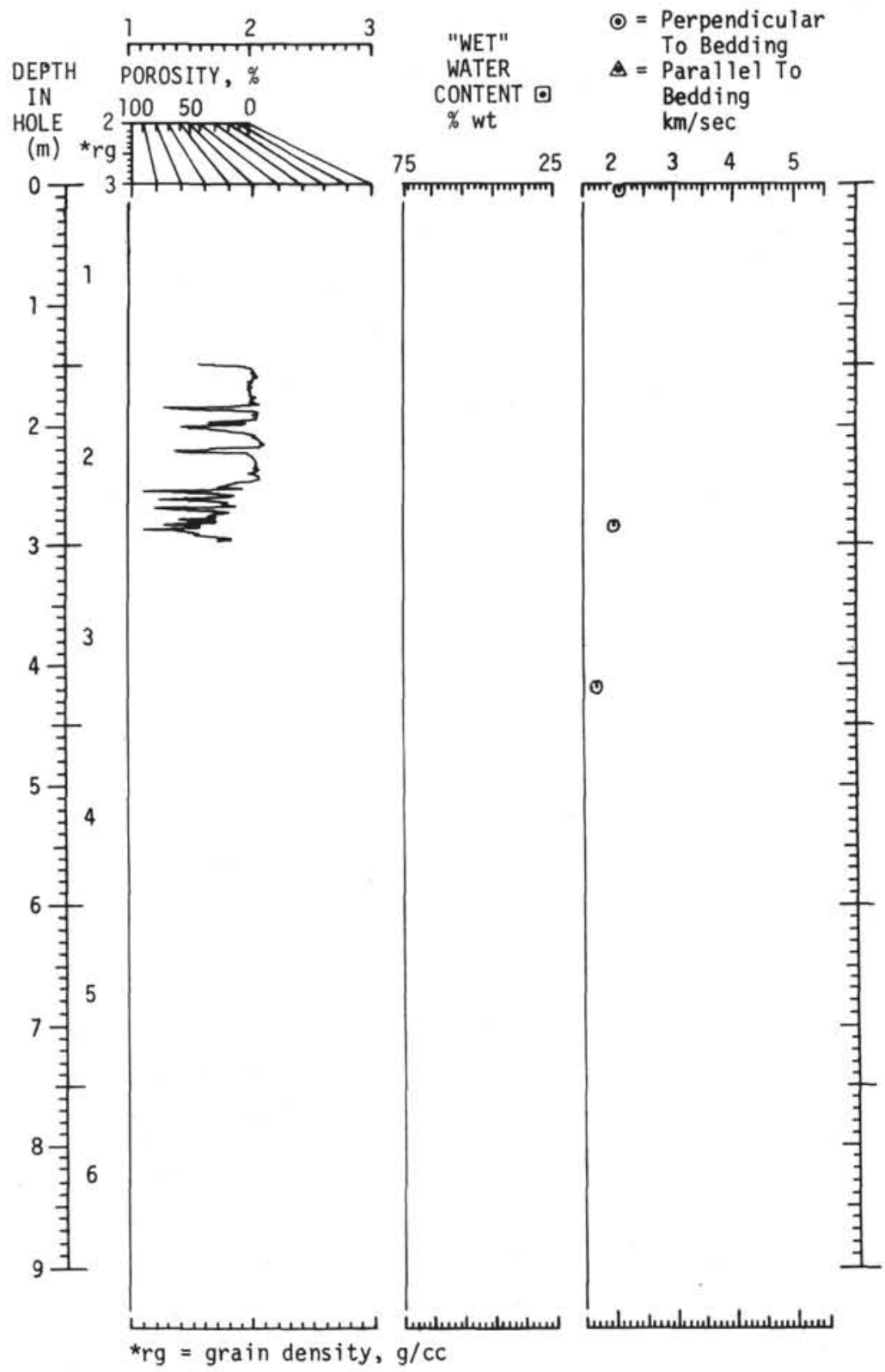

CORE $313-25$

- $=$ GRAPE WET-BULK DENSITY, $g / c c$

○ Syringe porosity,

COMPRESSIONAL SOUND VELOCITY

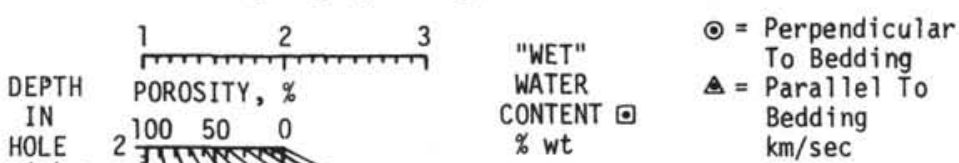

HOLE 2 TH $1000 \%$ wt

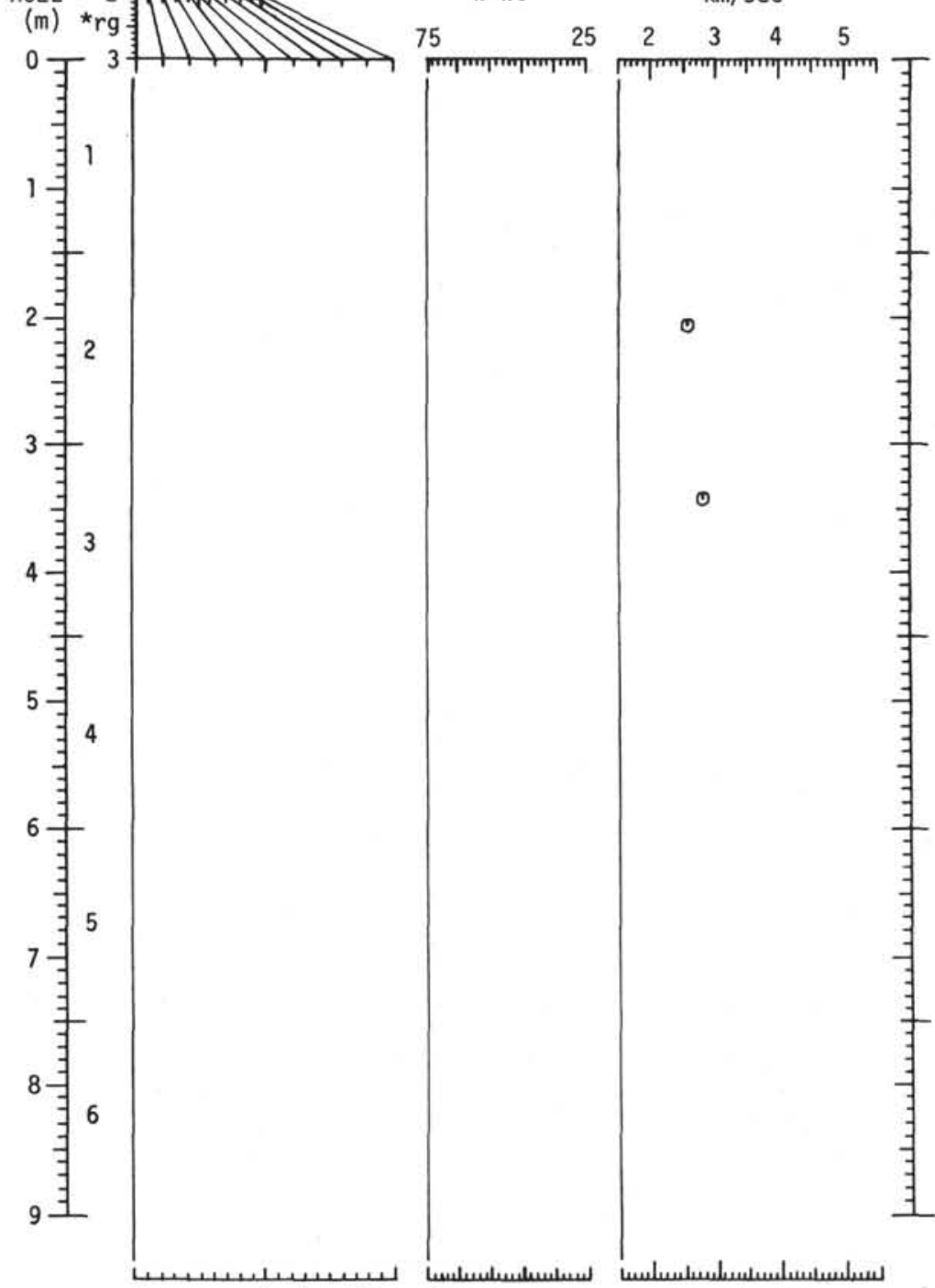

${ }^{*} r g=$ grain density, g/cc 
- Syringe porosity, \% COMPRESSIONAL SOUND VELOCITY

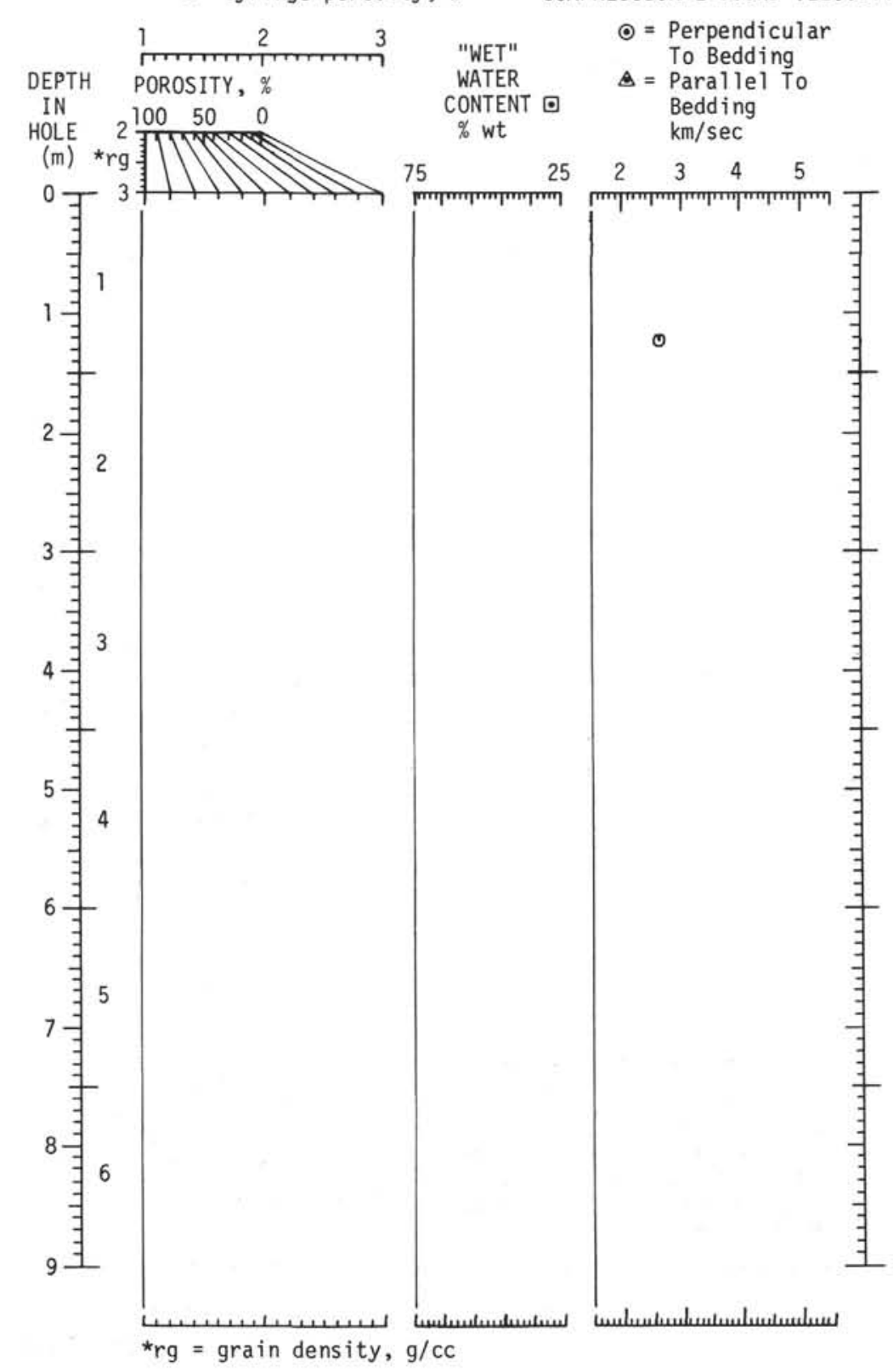

- = GRAPE WET-BULK DENSITY, g/cC

- Syringe porosity, \% COMPRESSIONAL SOUND VELOCITY

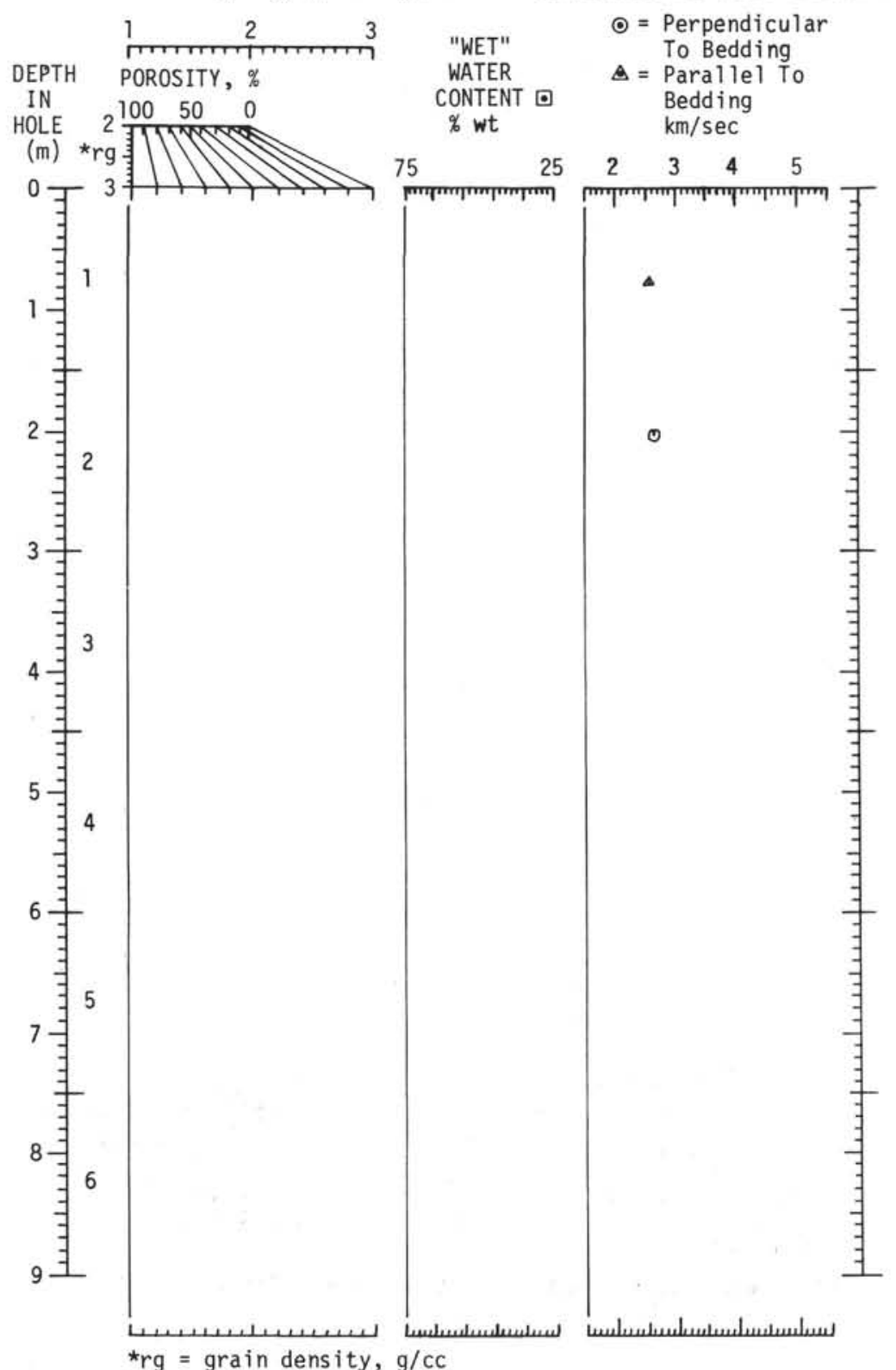


CORE $313-28$

$-=$ GRAPE WET-BULK DENSITY, $\mathrm{g} / \mathrm{cc}$

๑ Syringe porosity, \% COMPRESSIONAL SOUND VELOCITY

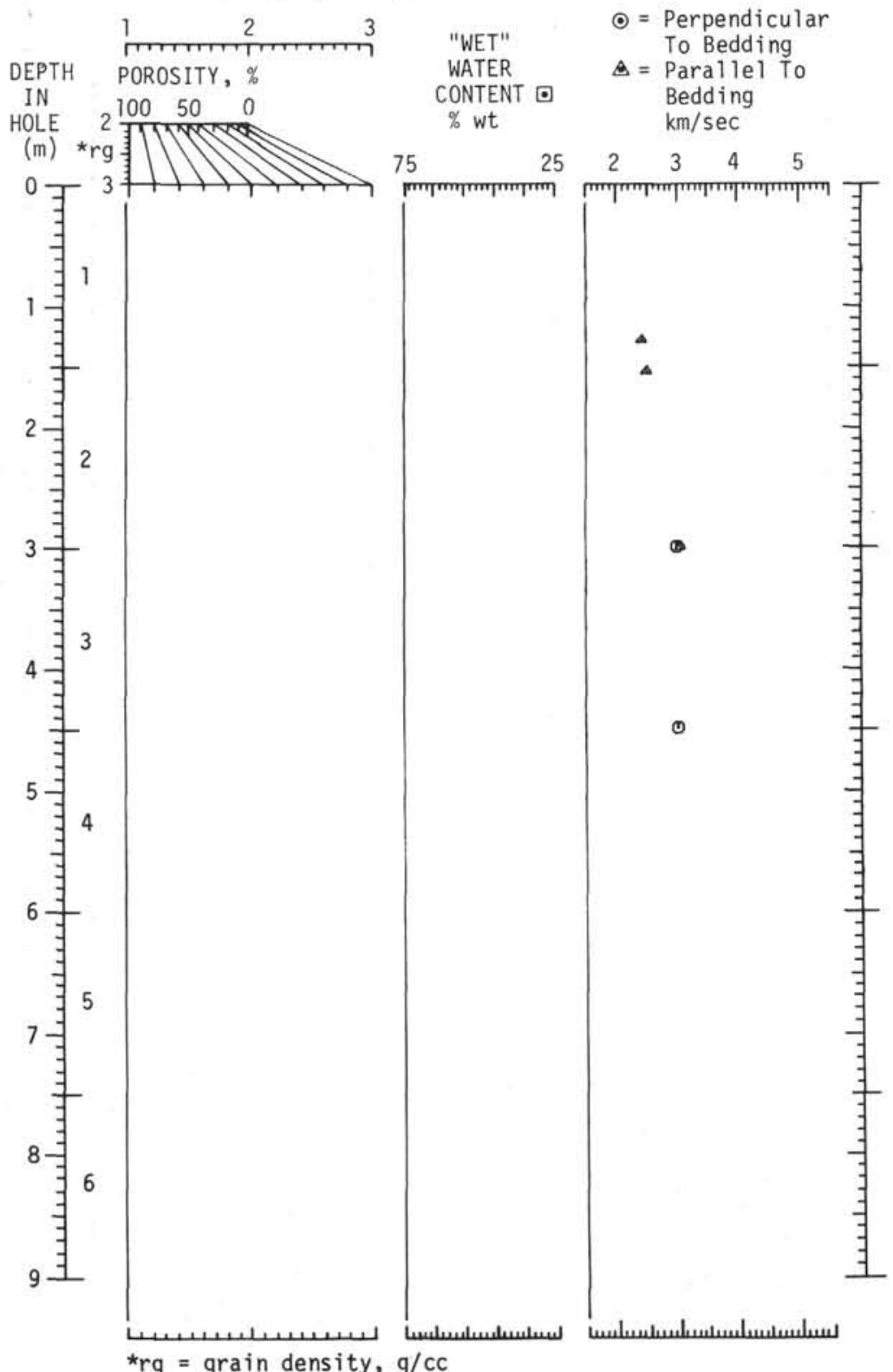

CORE $\quad 313-29$

- $=$ GRAPE WET-BULK DENSITY, $g / c C$

○ Syringe porosity, \%

COMPRESSIONAL SOUND VELOCITY

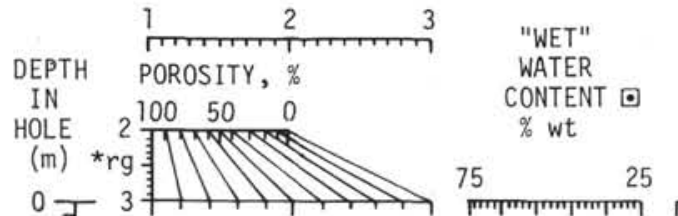

$\odot=$ Perpendicular To Bedding

= Parallel To Bedding $\mathrm{km} / \mathrm{sec}$

$\begin{array}{llll}2 & 3 & 4 & 5\end{array}$

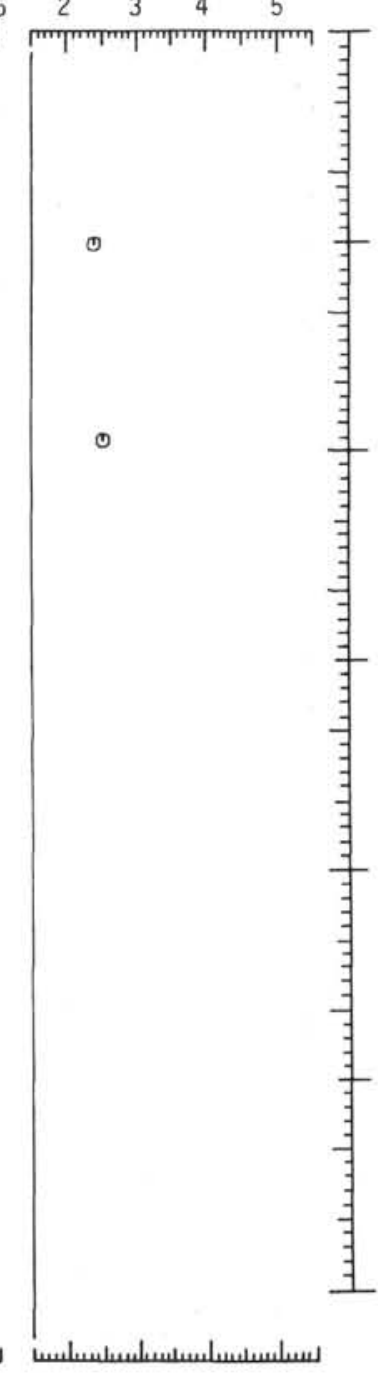


$-=$ GRAPE WET-BULK DENSITY, $\mathrm{g} / \mathrm{cC}$

- Syringe porosity, $\%$ COMPRESSIONAL SOUND VELOCITY

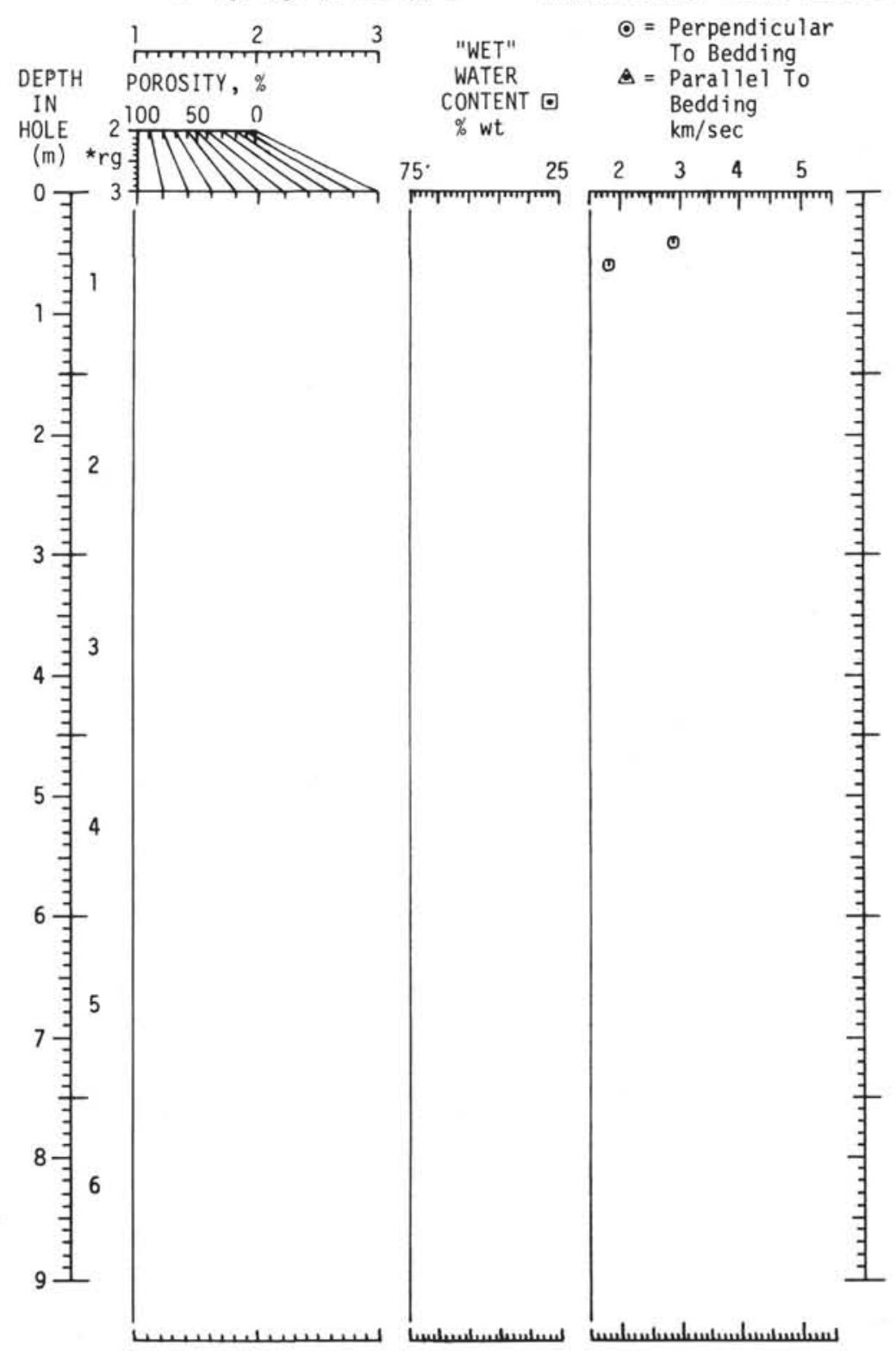

$-=$ GRAPE WET-BULK DENSITY, $g / c C$

- Syringe porosity, \% COMPRESSIONAL SOUND VELOCITY

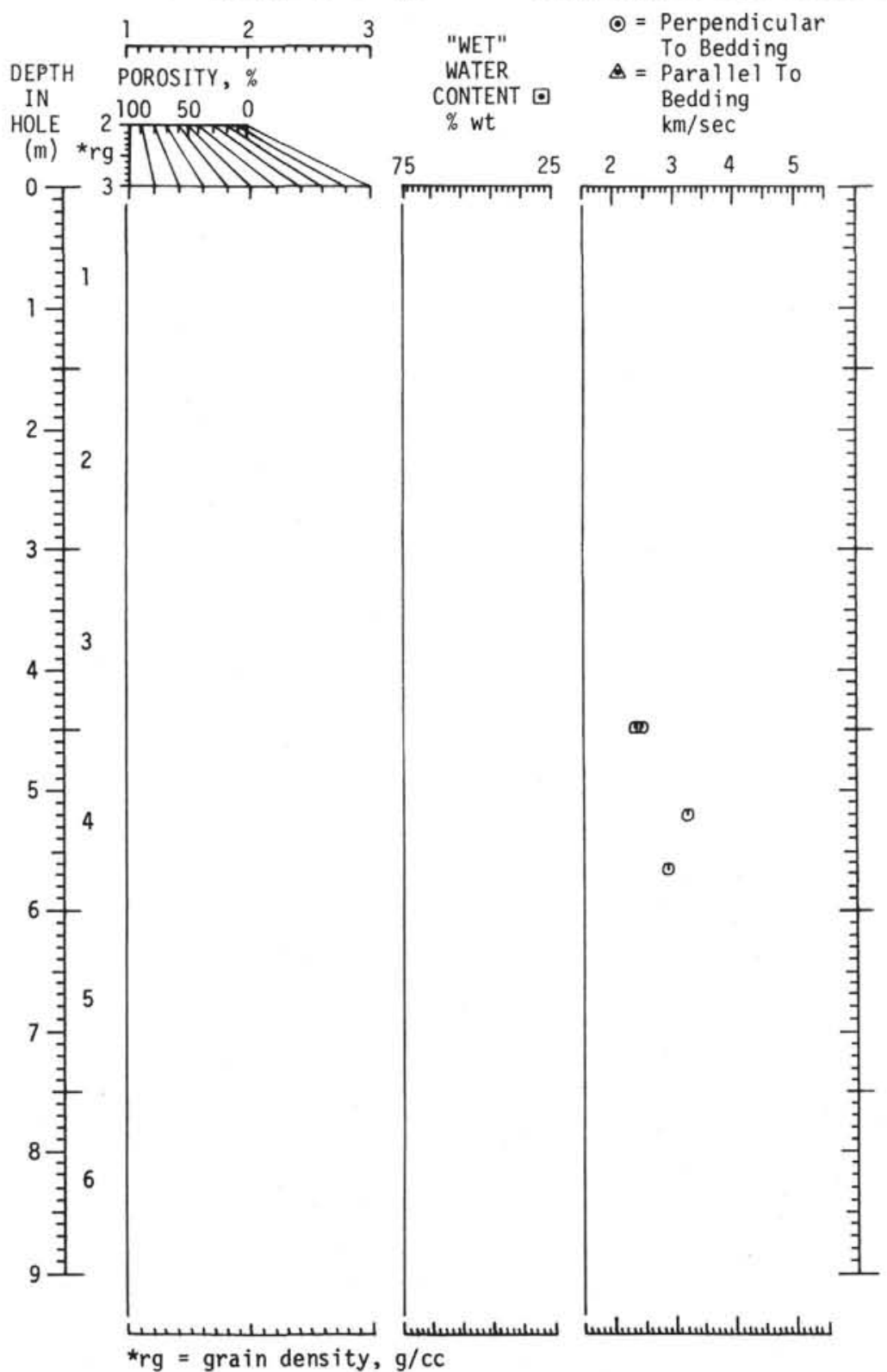


CORE $313-35$

- $=$ GRAPE WET-BULK DENSITY, g/cC

○ Syringe porosity, $\%$ COMPRESSIONAL SOUND VELOCITY

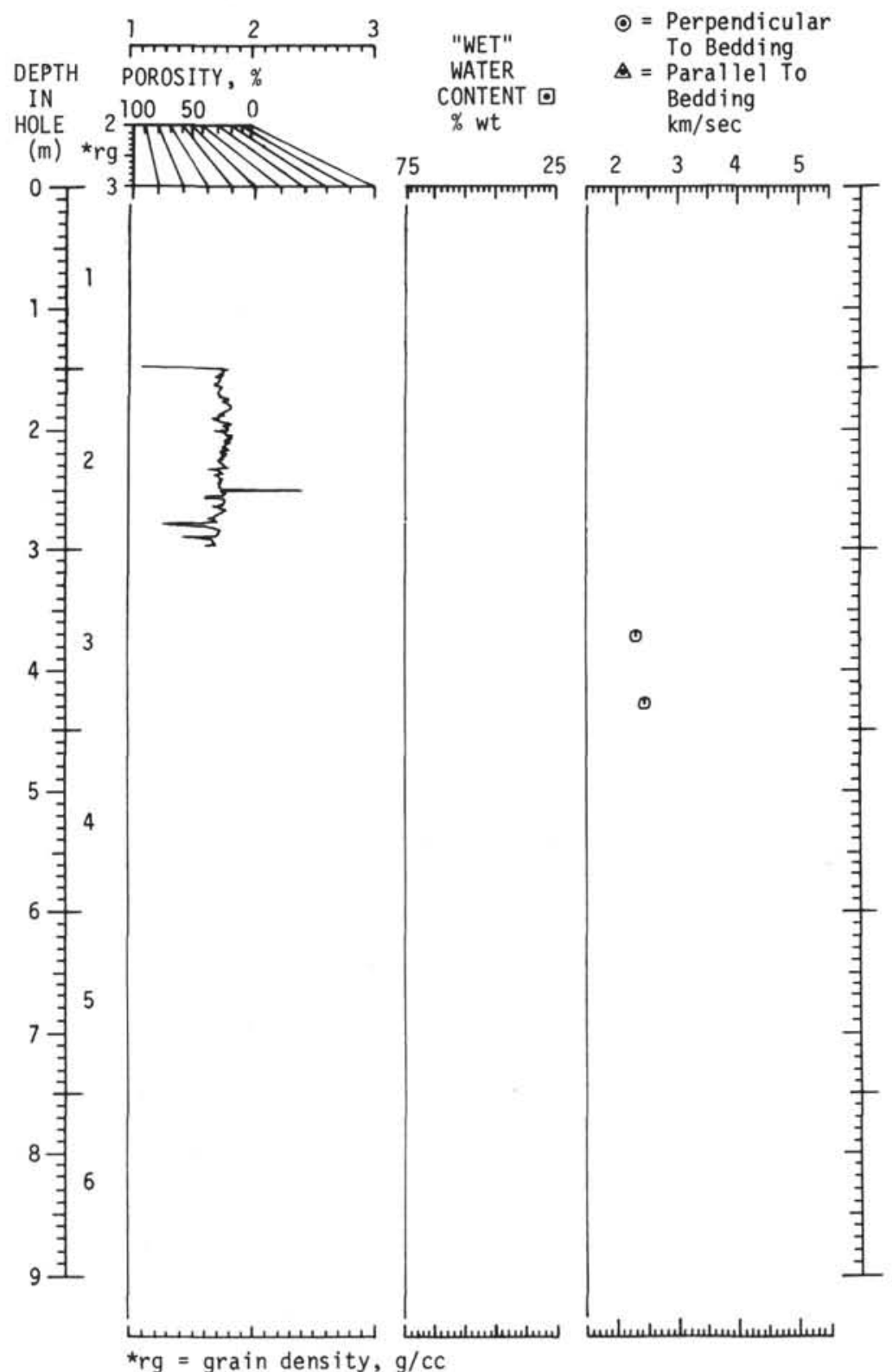

CORE $313-36$

- $=$ GRAPE WET-BULK DENSITY, $g / c c$

- Syringe porosity, \% COMPRESSIONAL SOUND VELOCITY

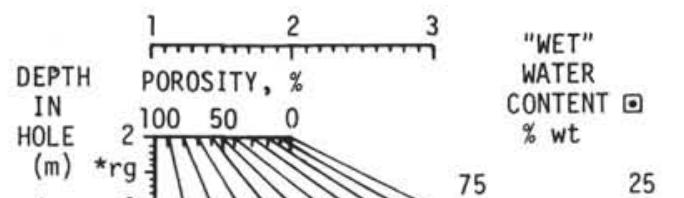

0 = Perpendicular To Bedding Parallel Bedding

$\begin{array}{llll}2 & 3 & 4 & 5\end{array}$

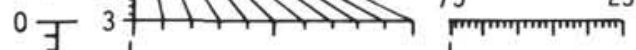

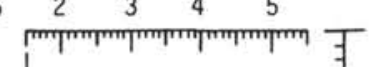

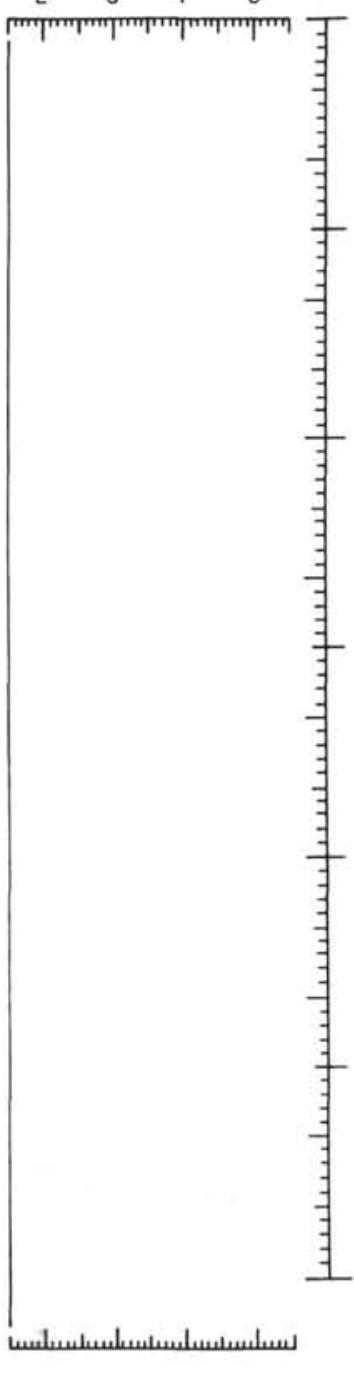


- Syringe porosity, \% COMPRESSIONAL SOUND VELOCITY

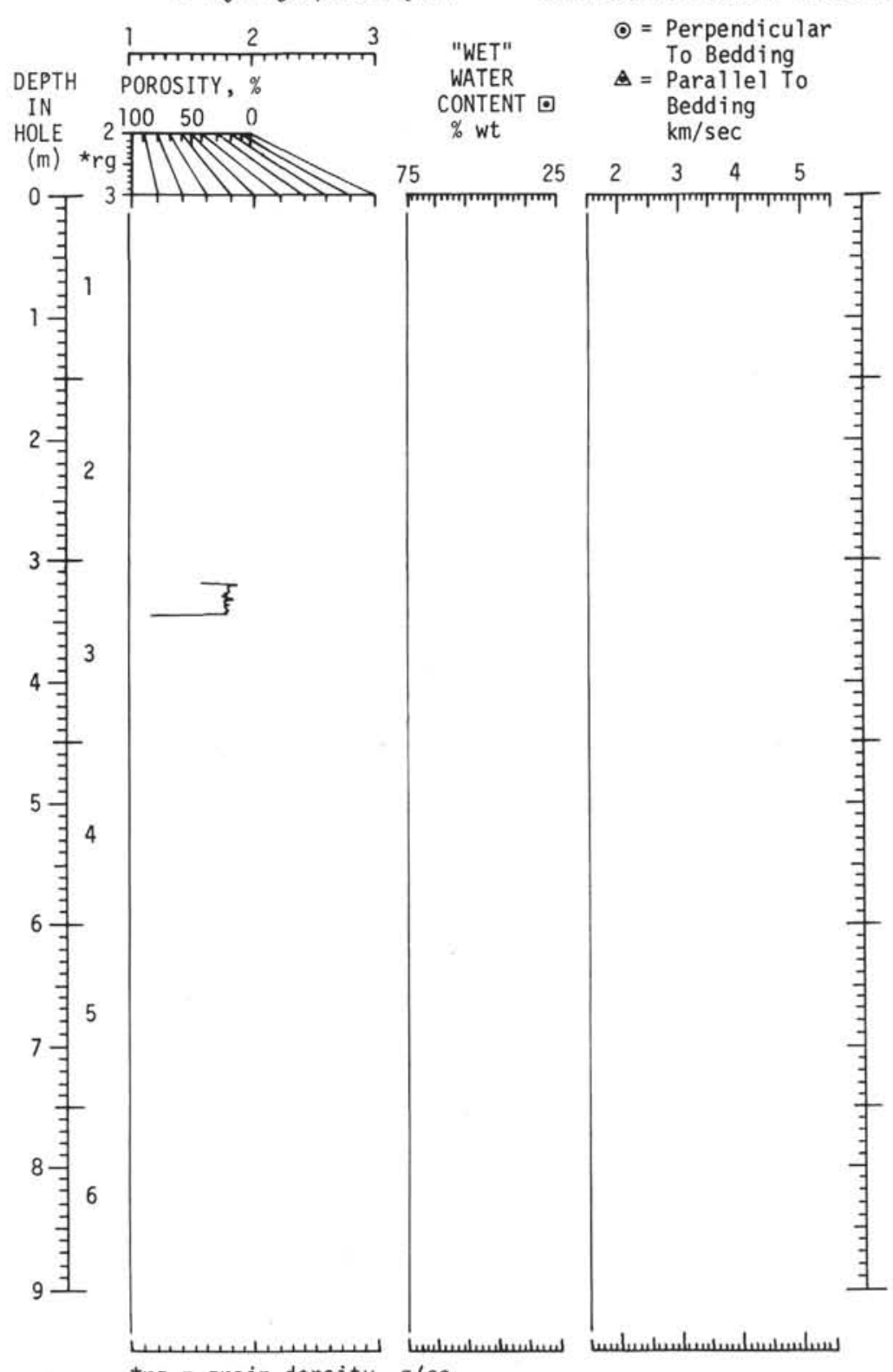

- $=$ GRAPE WET-BULK DENSITY, g/cC

- Syringe porosity, \% COMPRESSIONAL SOUND VELOCITY

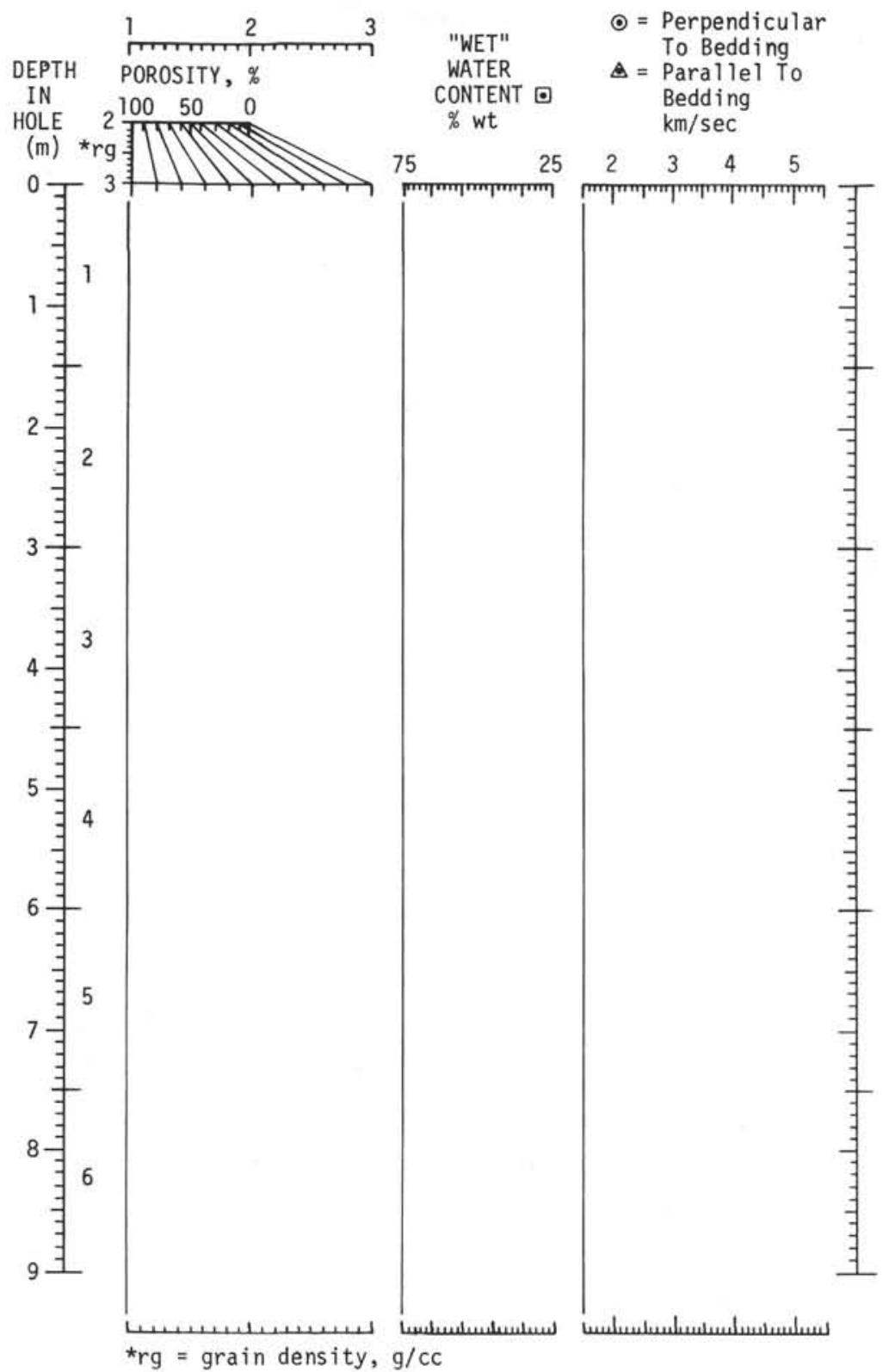


CORE $313-39$

$-=$ GRAPE WET-BULK DENSITY, $\mathrm{g} / \mathrm{cC}$

- Syringe porosity, \% COMPRESSIONAL SOUND VELOCITY

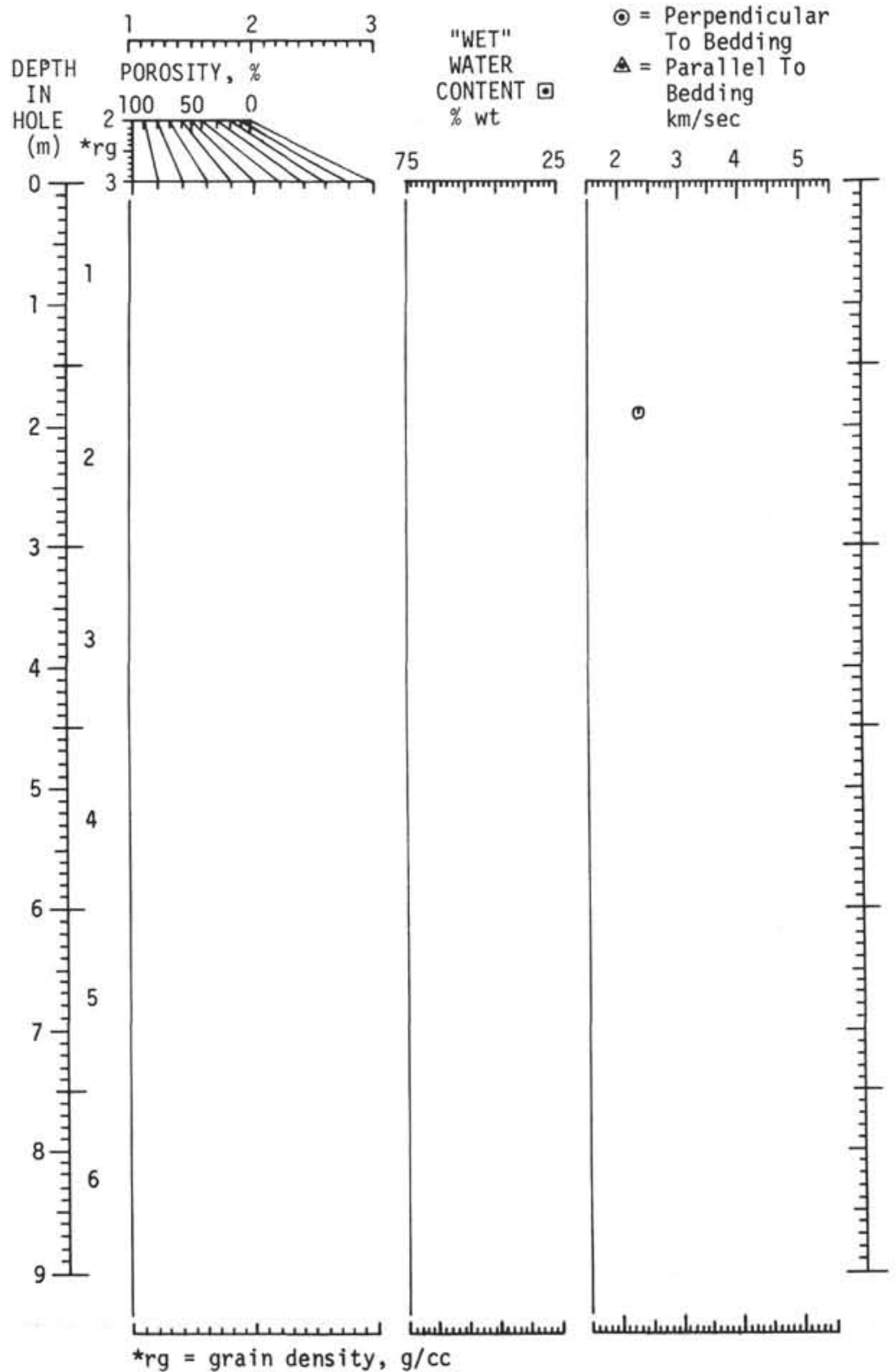

CORE $\quad 313-41$

$-=$ GRAPE WET-BULK DENSITY, $\mathrm{g} / \mathrm{cc}$

○ Syringe porosity, \% COMPRESSIONAL SOUND VELOCITY

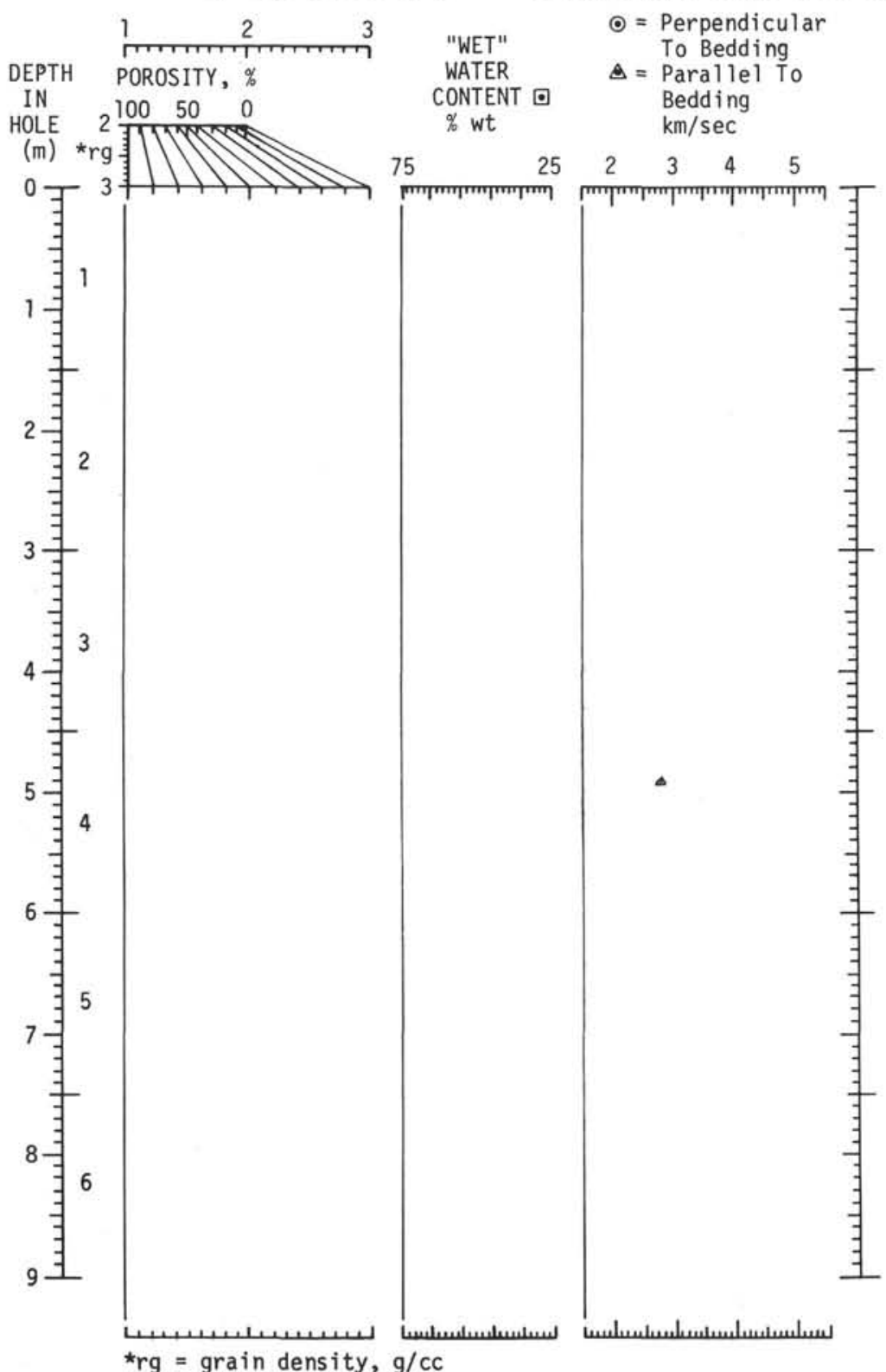


- Syringe porosity, \% COMPRESSIONAL SOUND VELOCITY

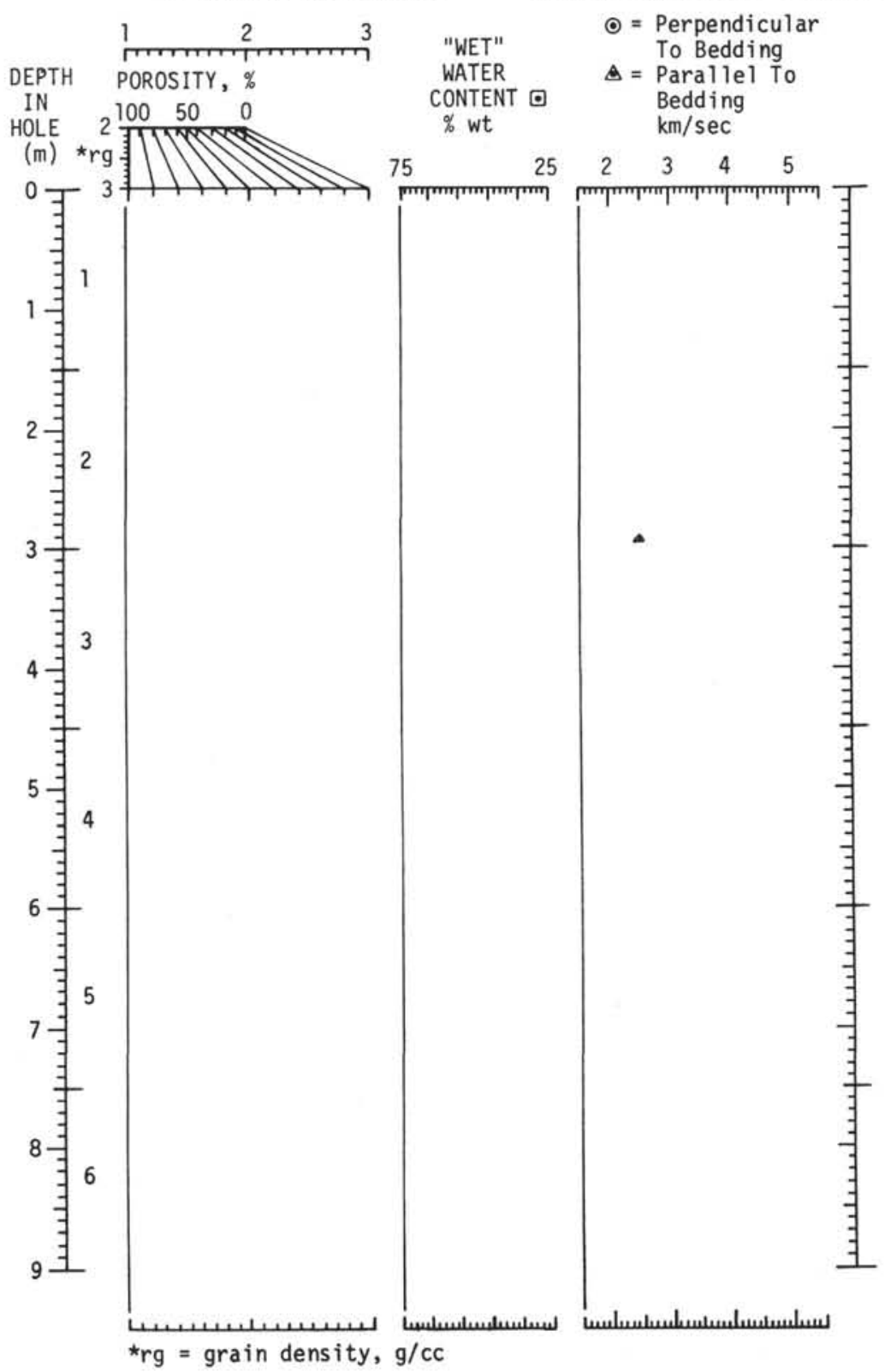

$-=$ GRAPE WET-BULK DENSITY, $g / c c$

- Syringe porosity, \% COMPRESSIONAL SOUND VELOCITY

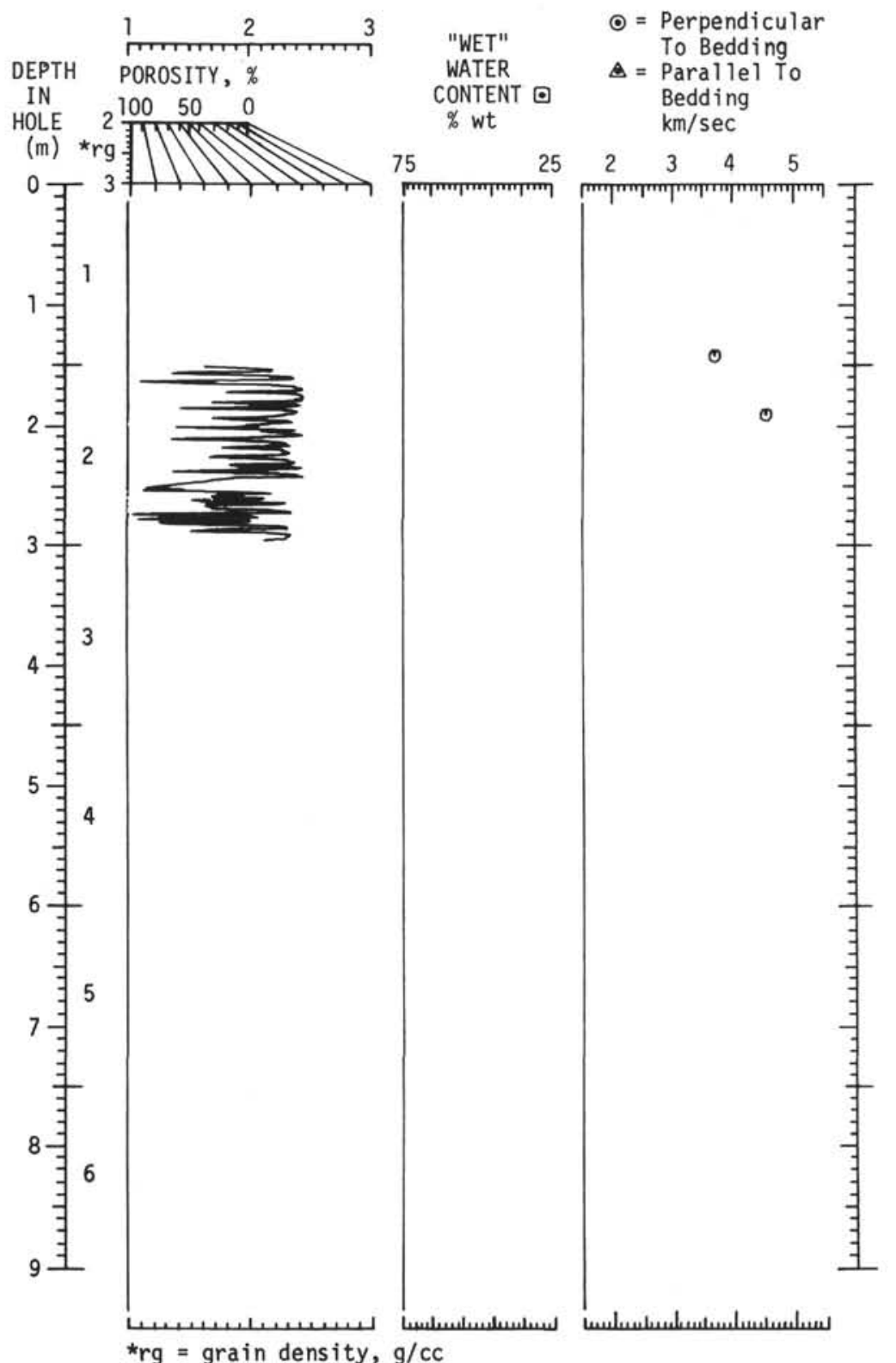


CORE $\quad 313-44$

- = GRAPE WET-BULK DENSITY, g/cC

- Syringe porosity, \% COMPRESSIONAL SOUND VELOCITY

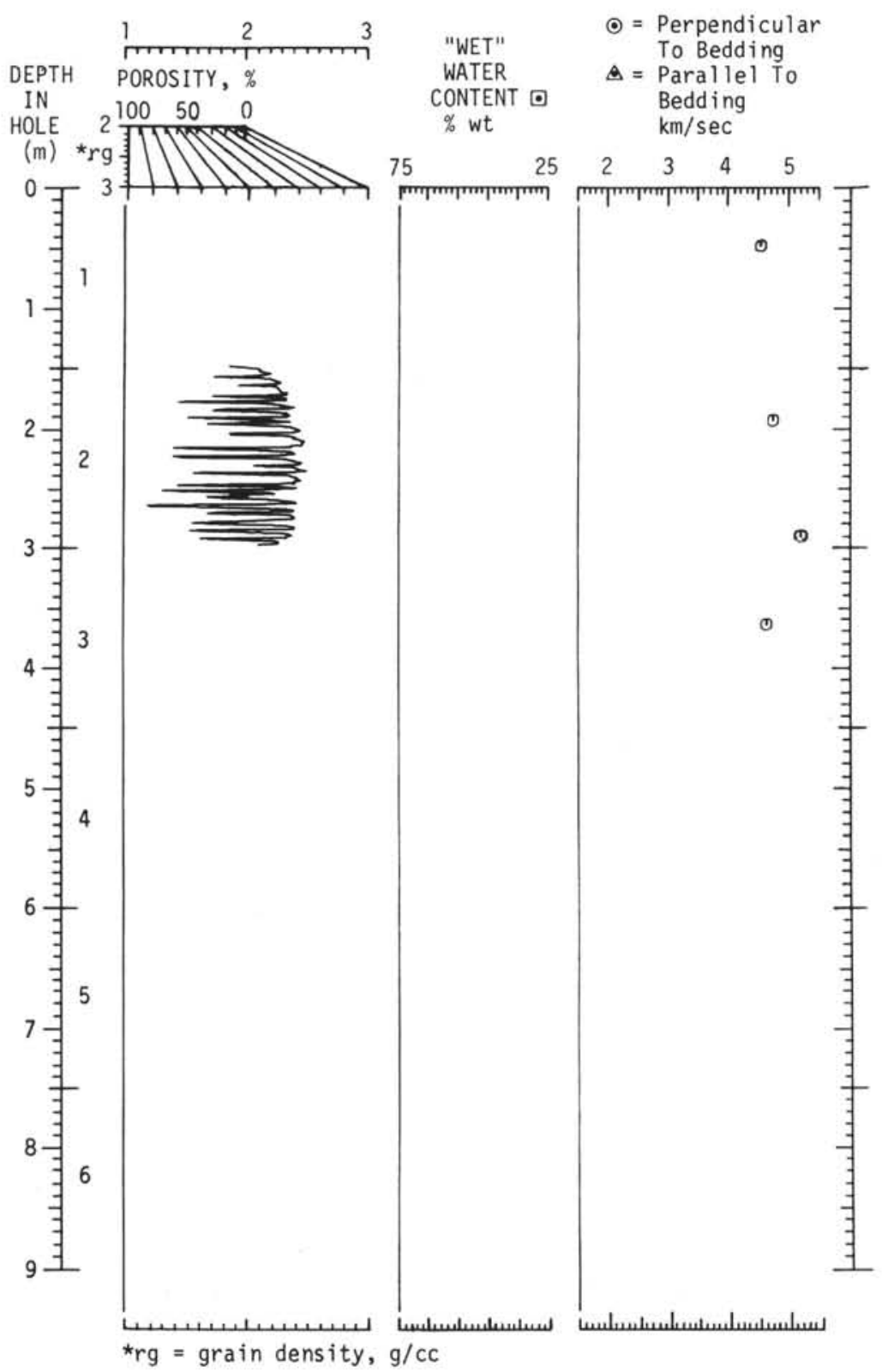




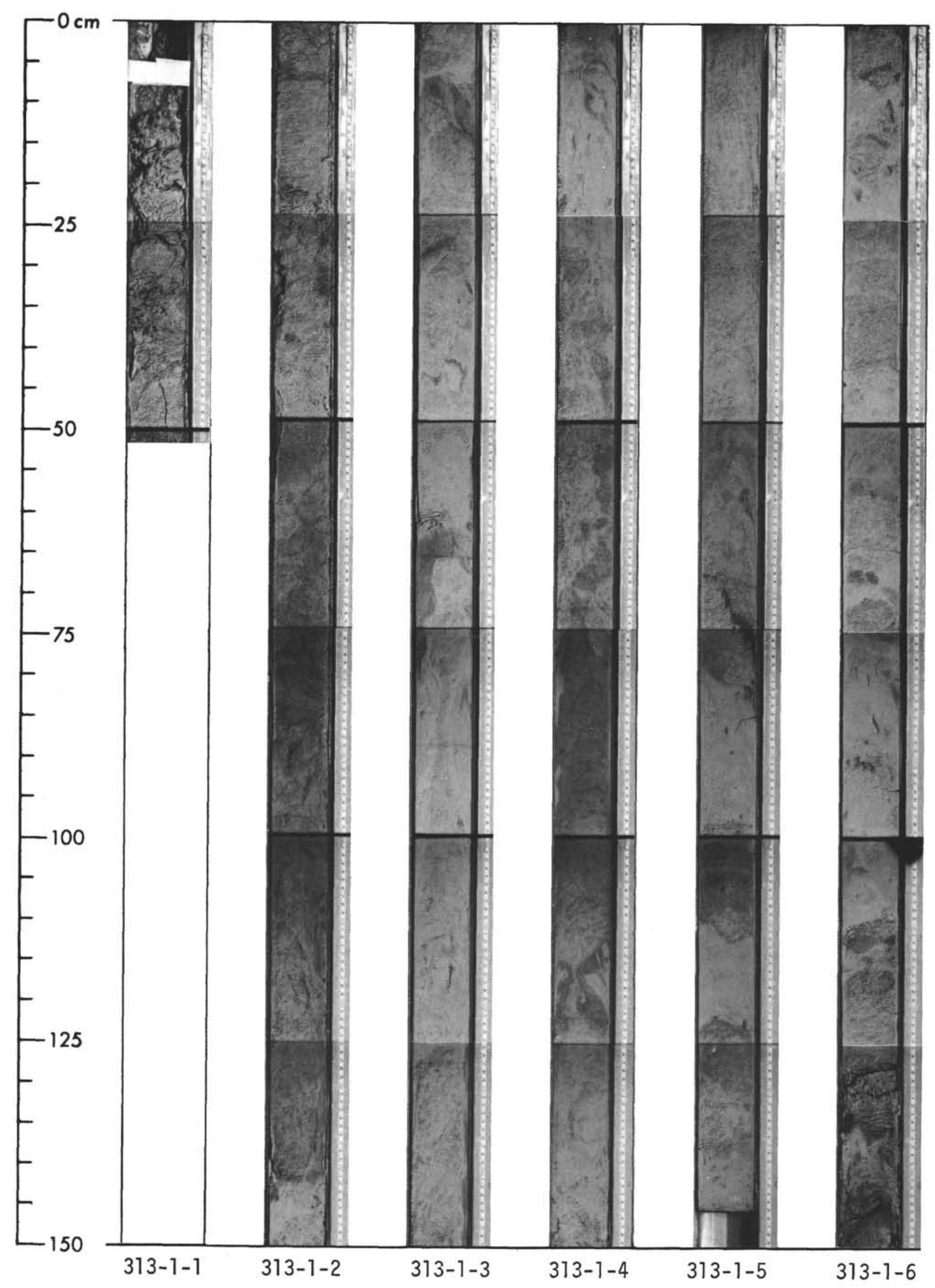




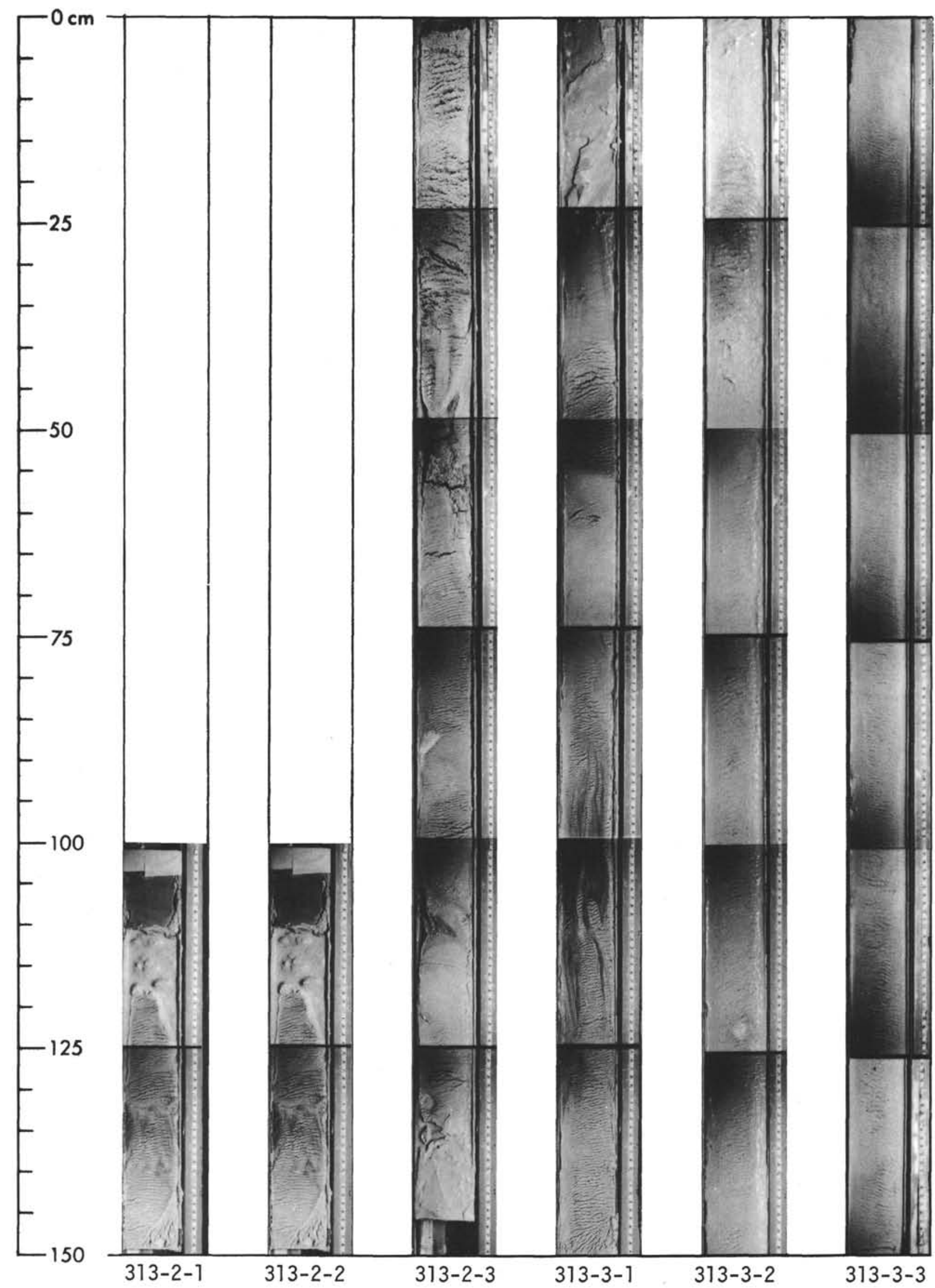




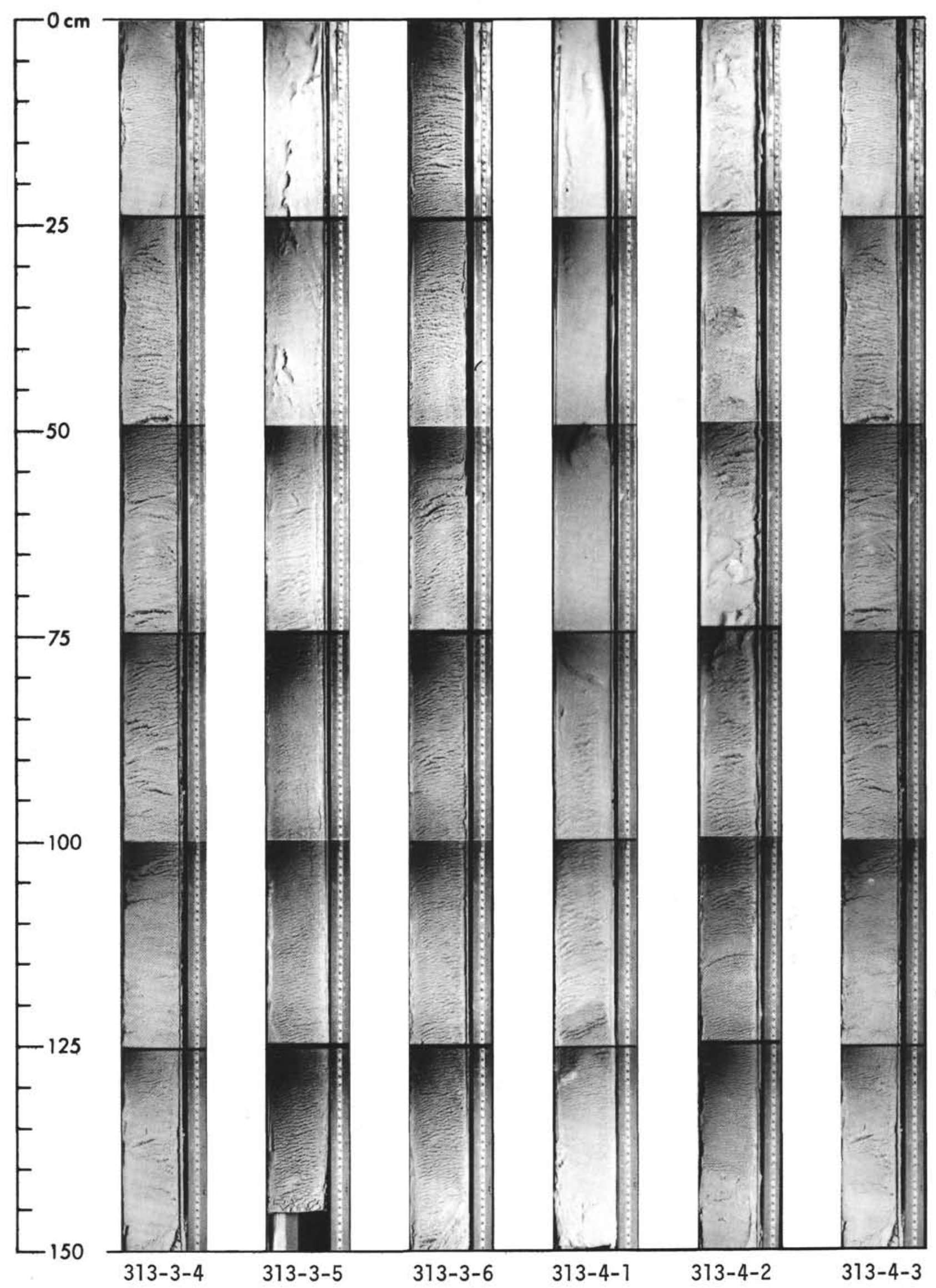




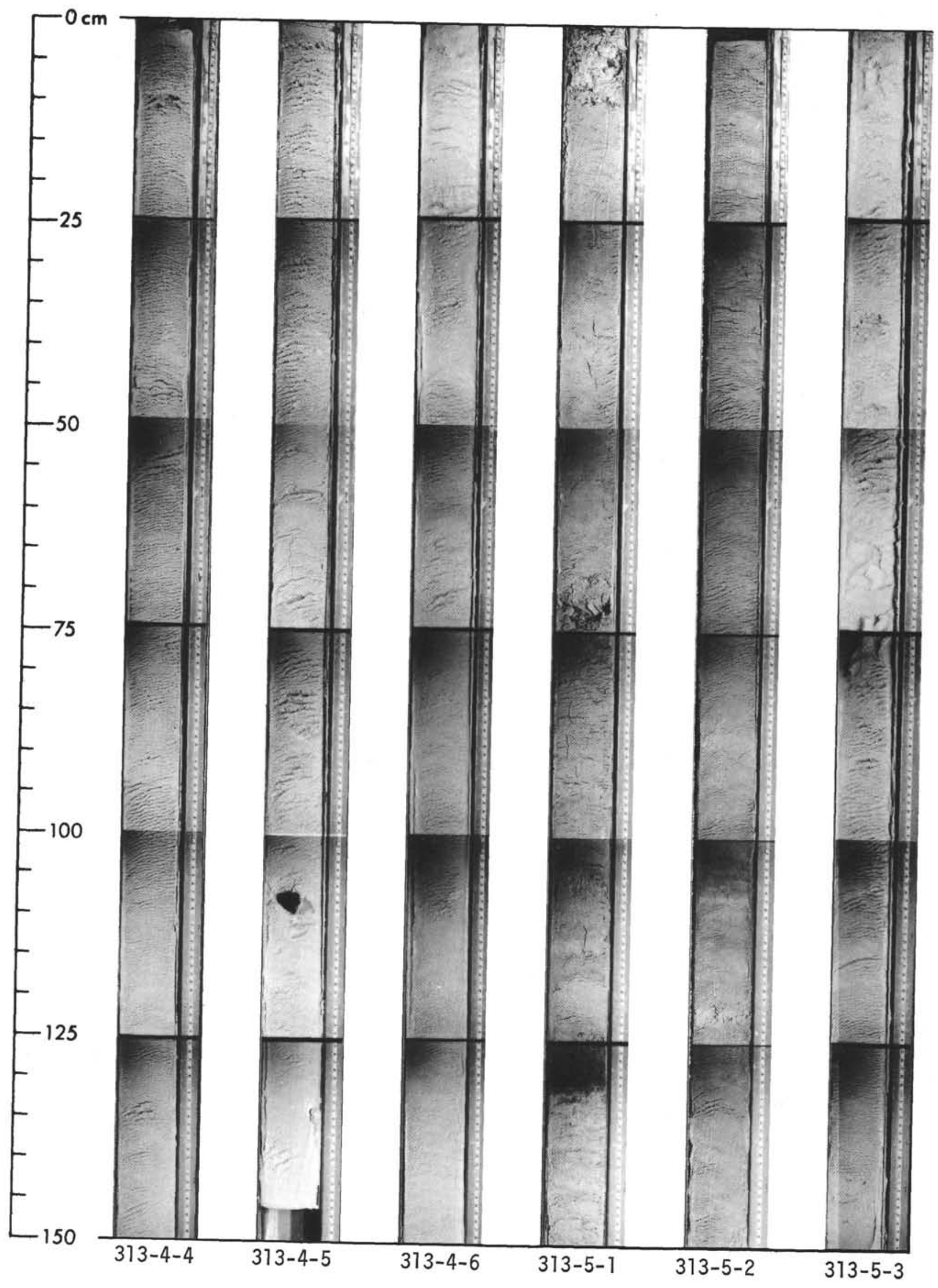




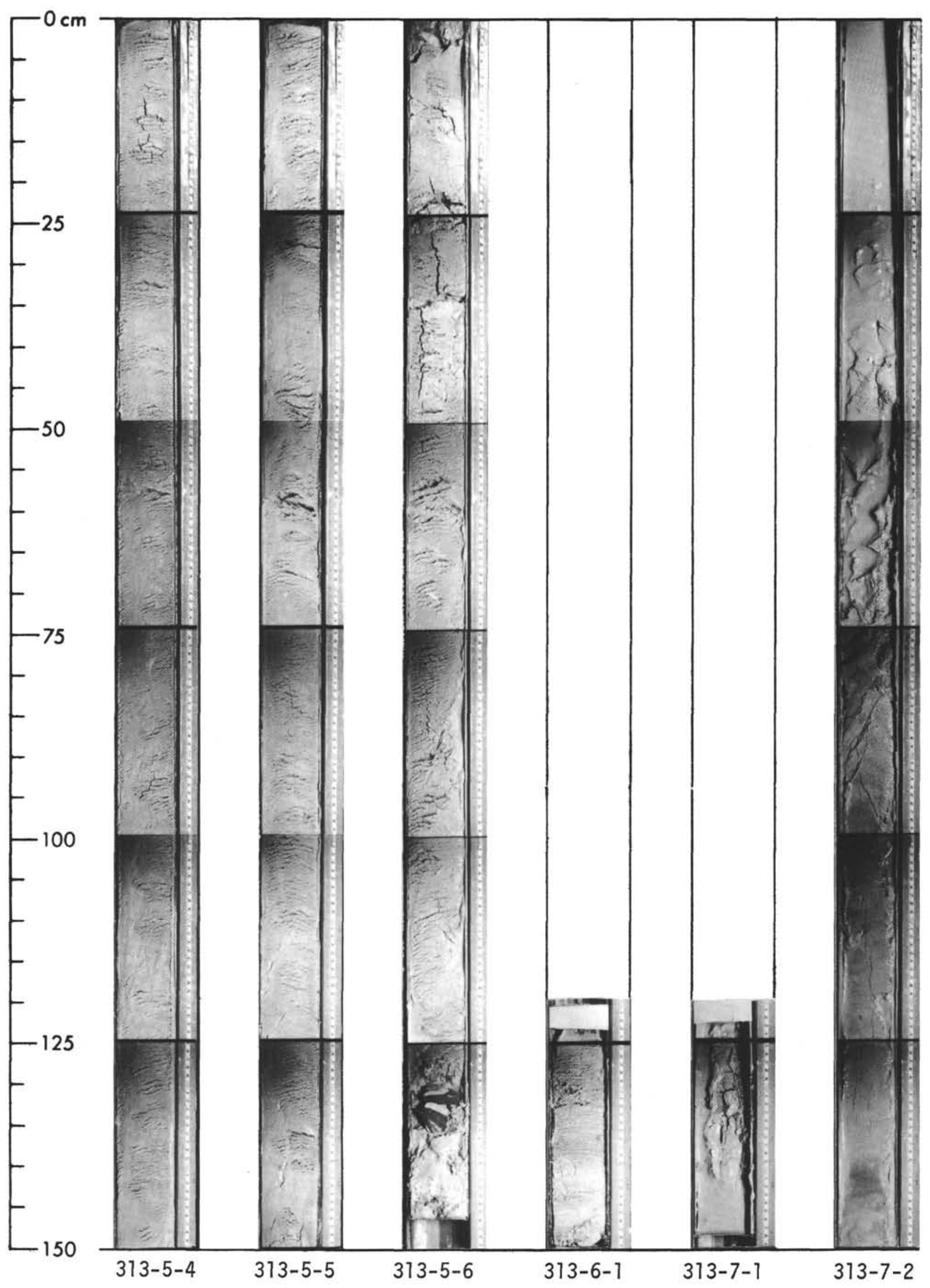




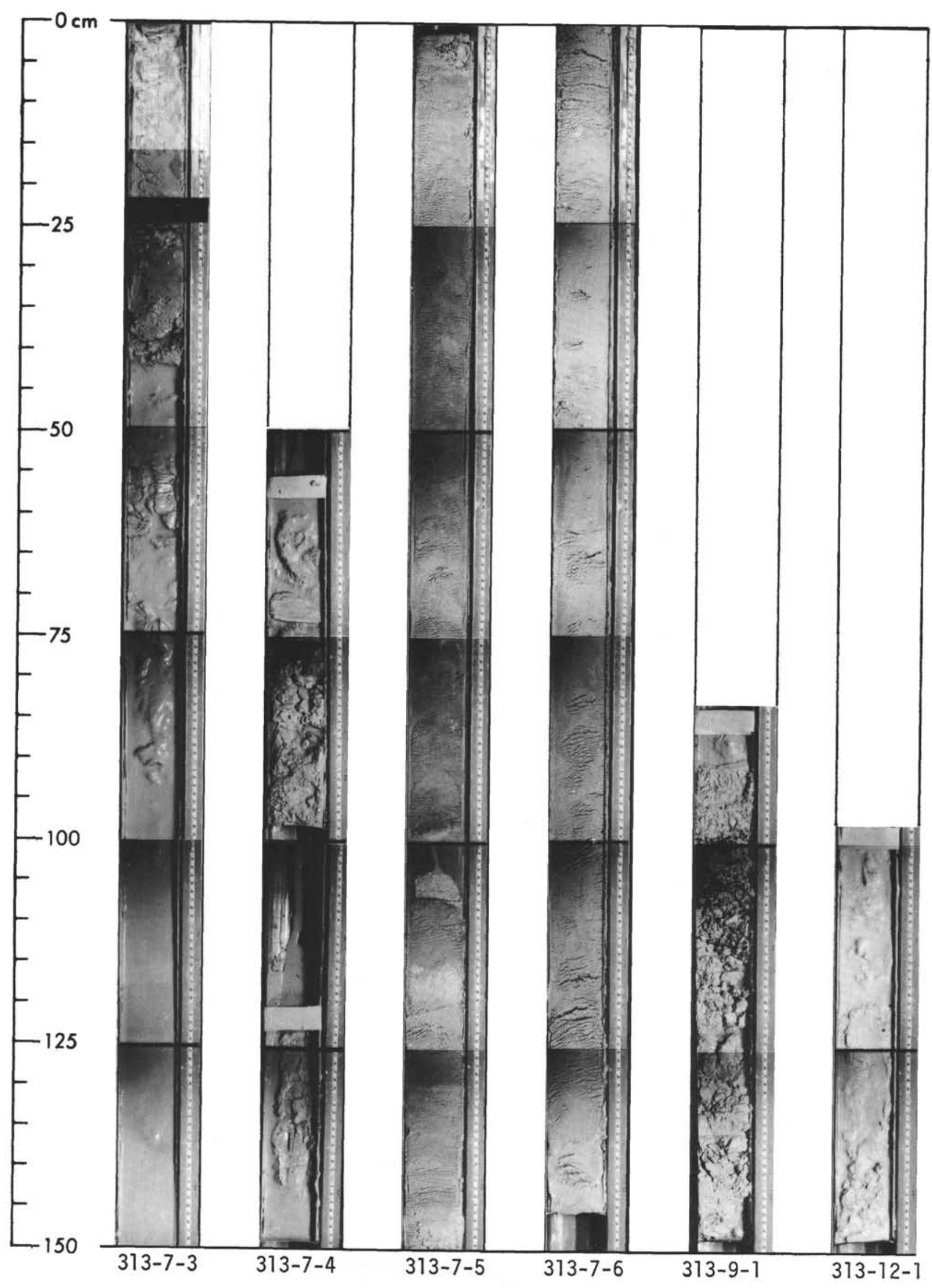




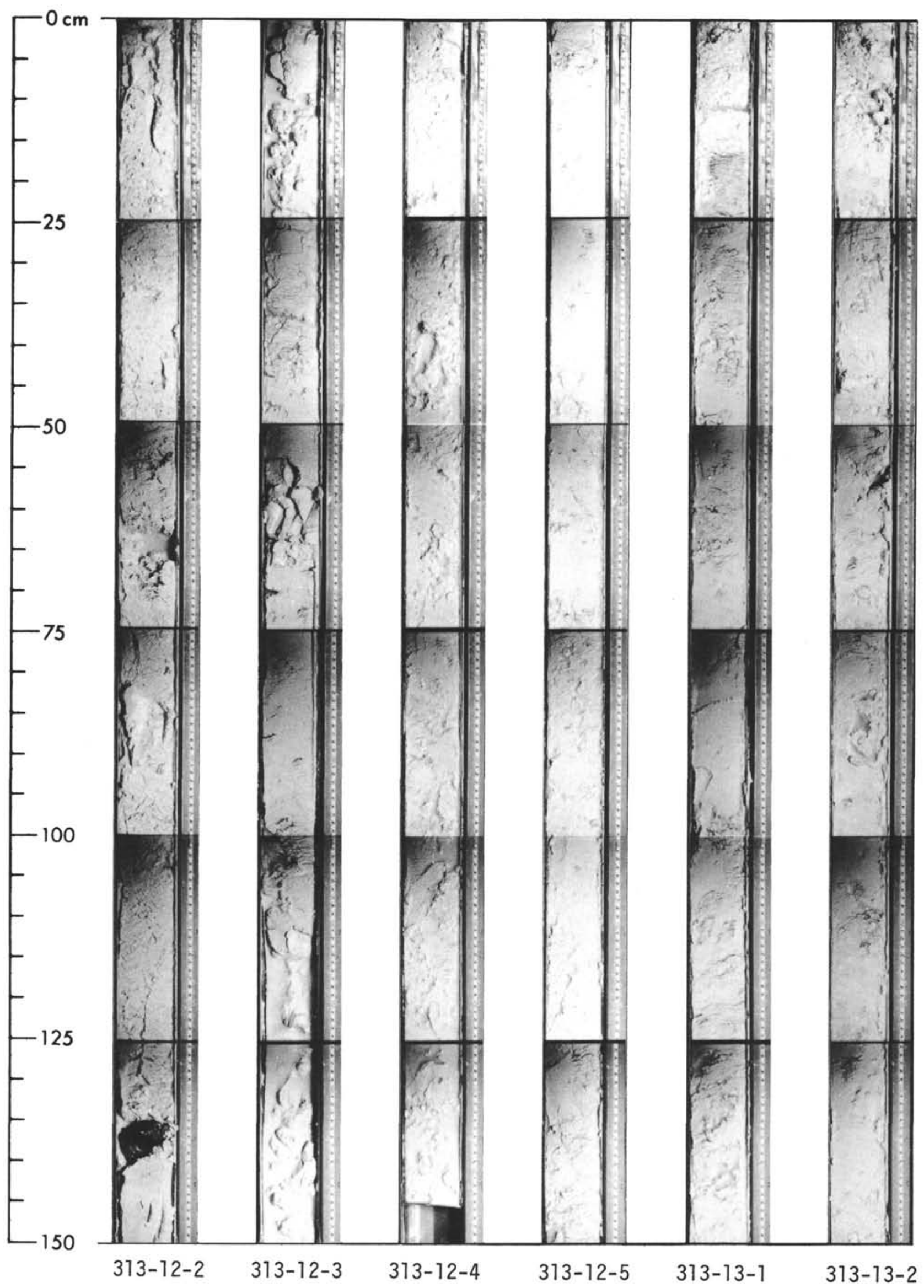




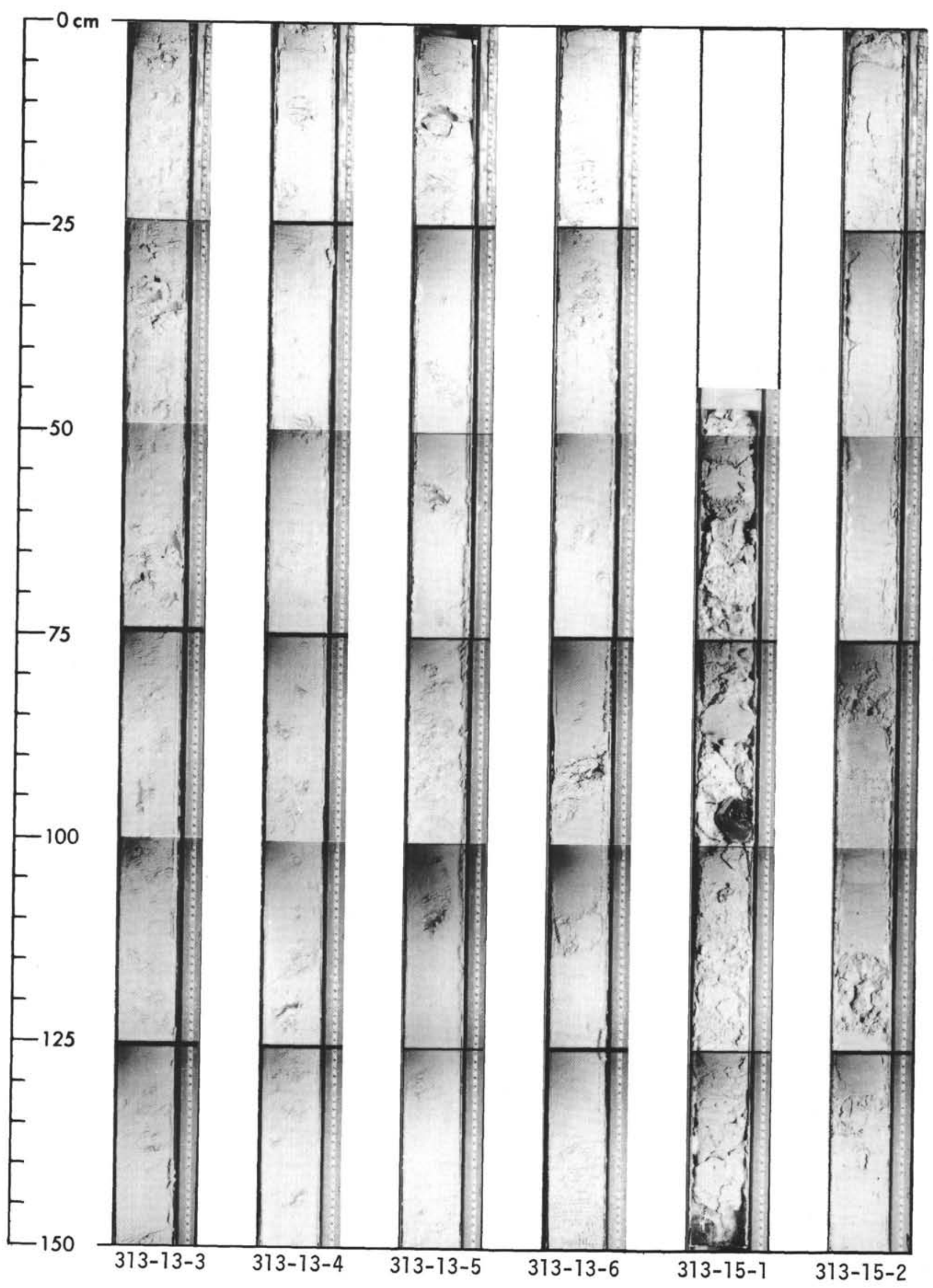




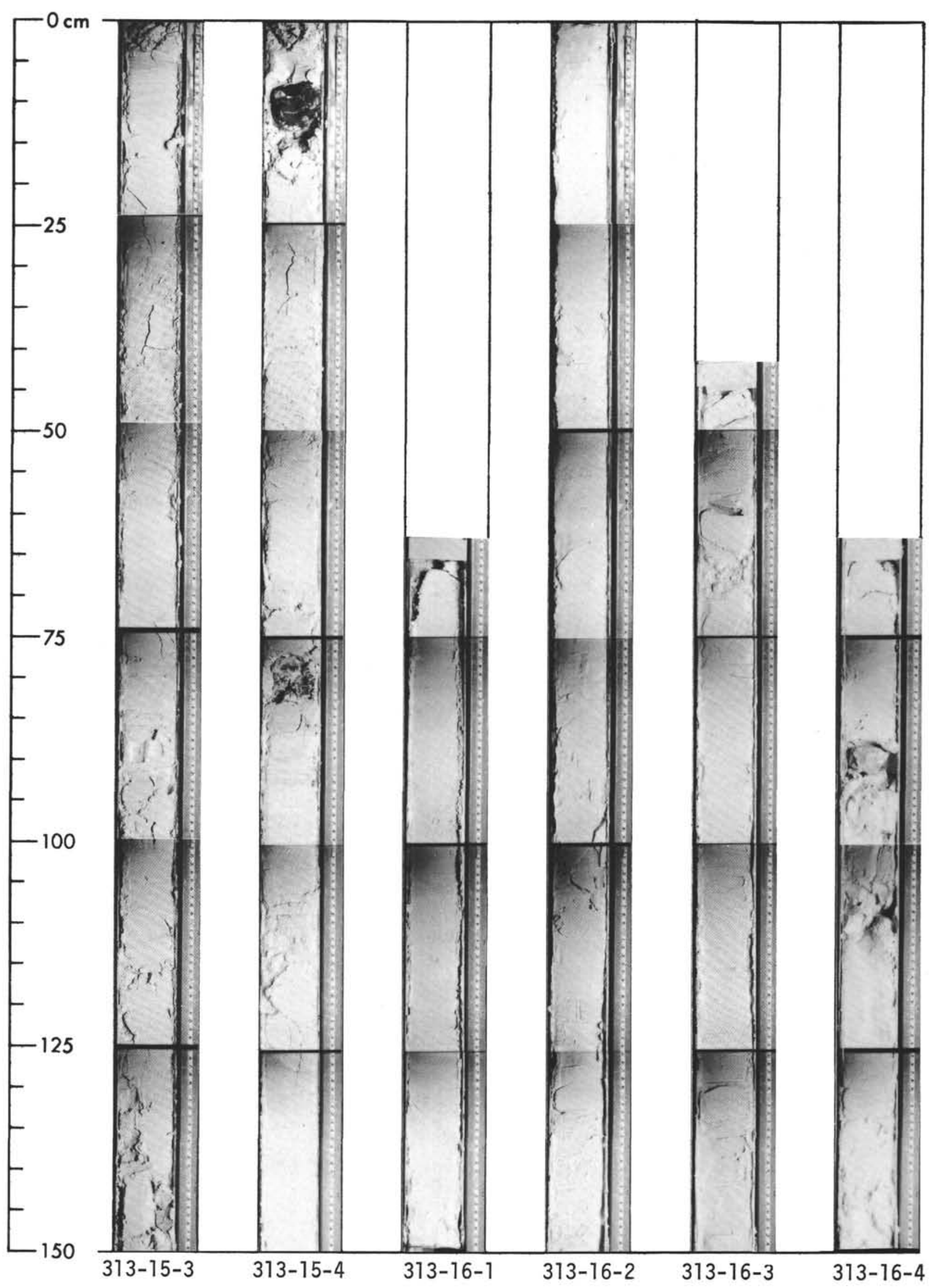




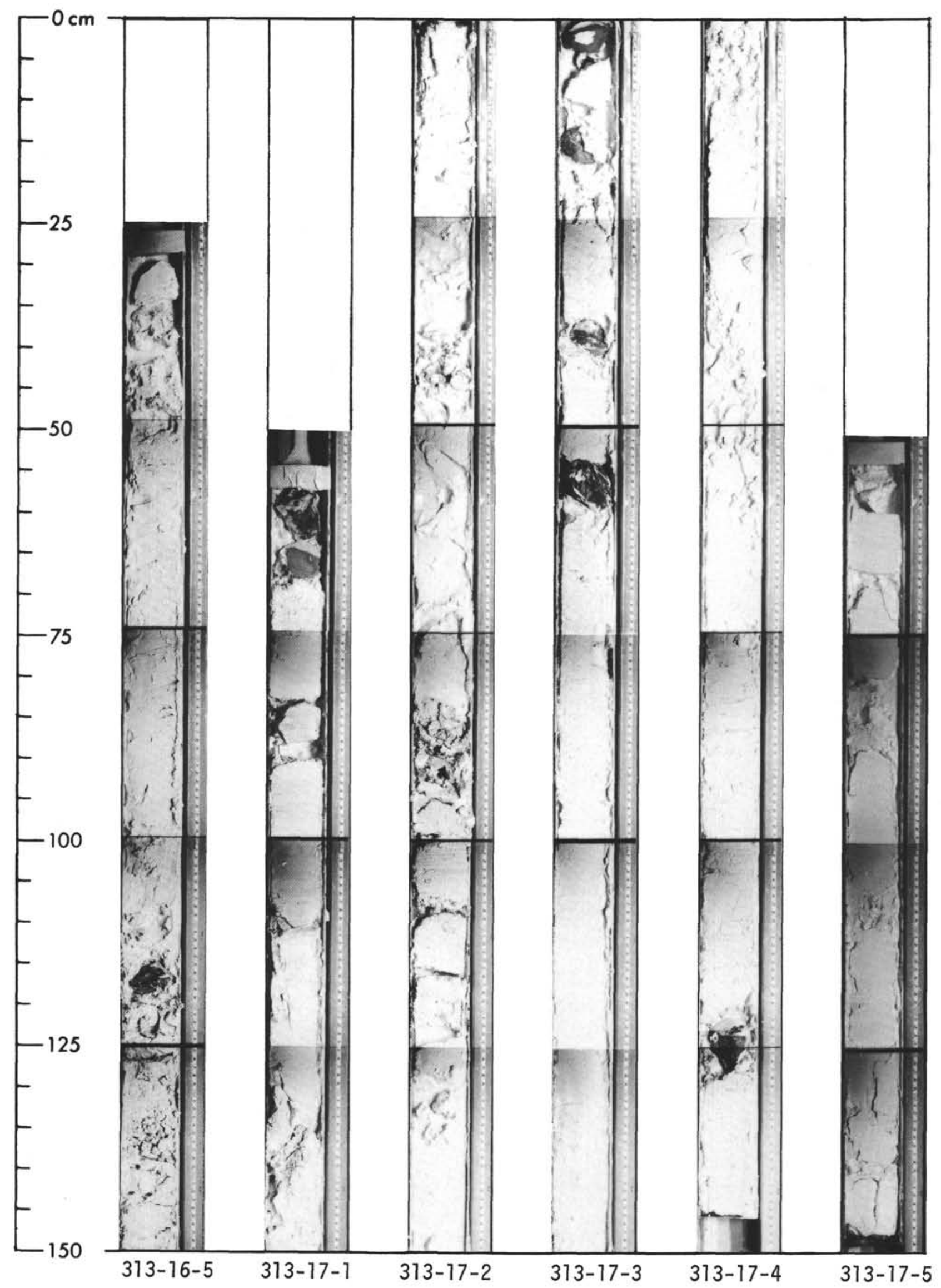




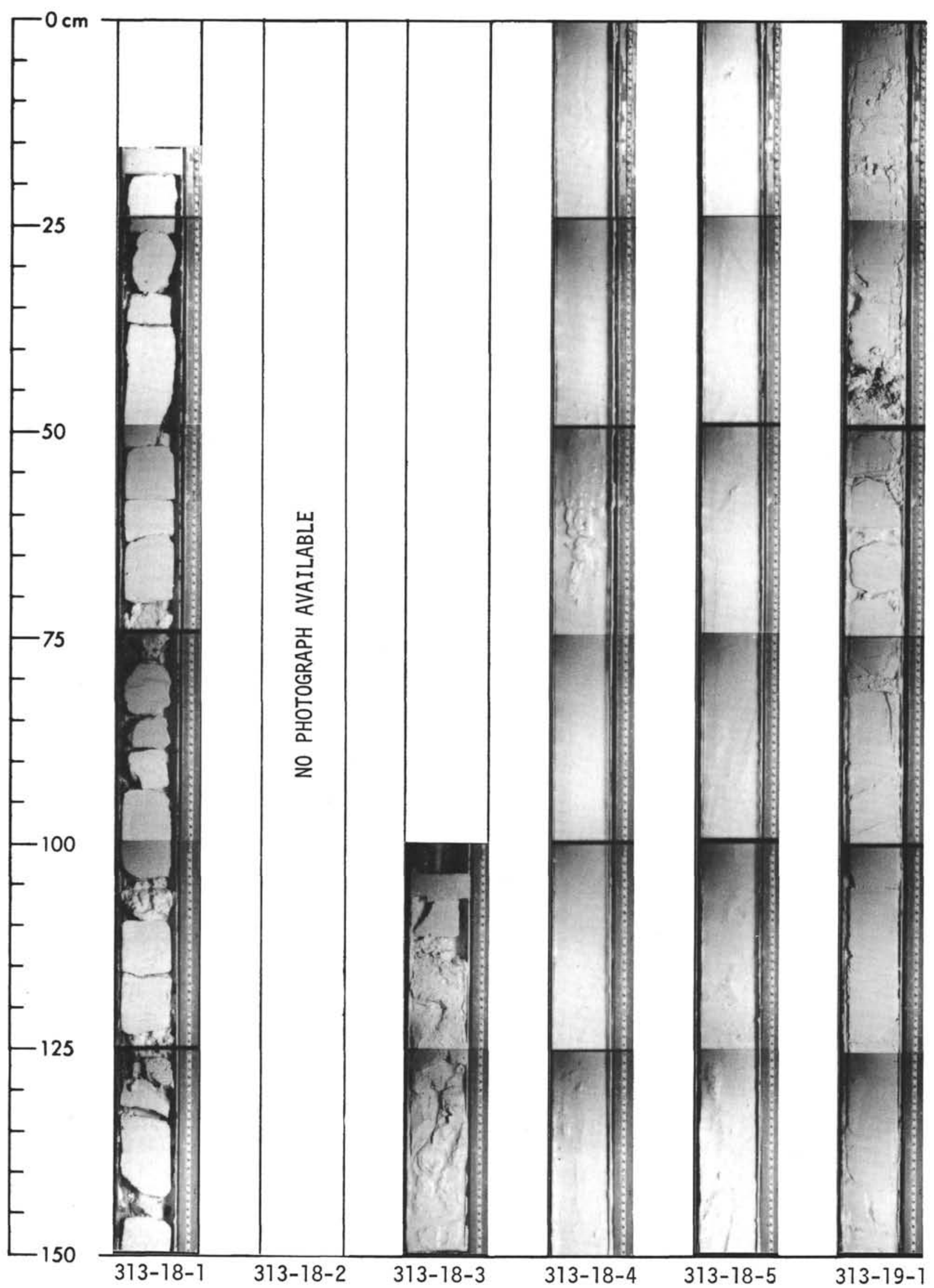


SITE 313

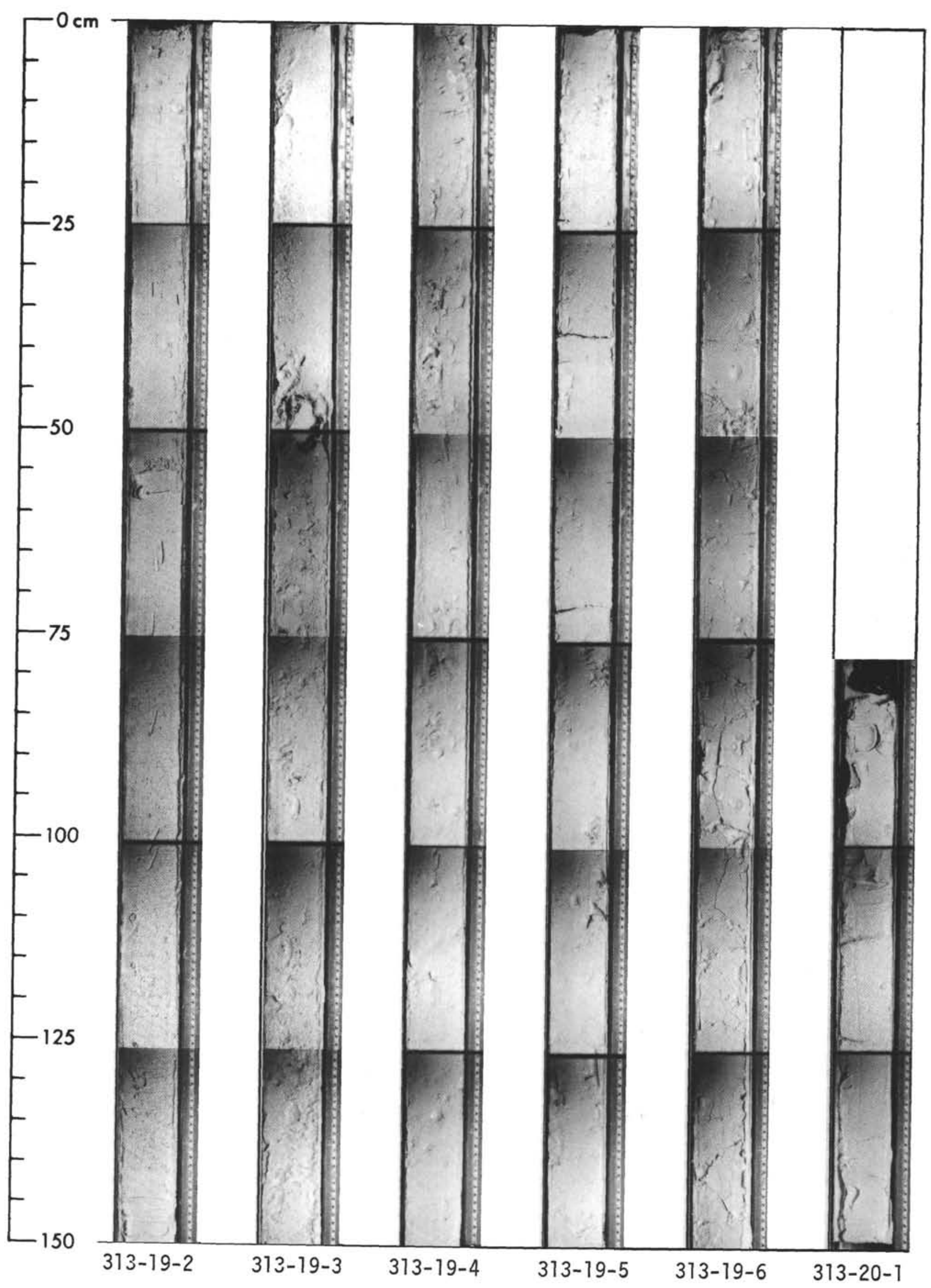




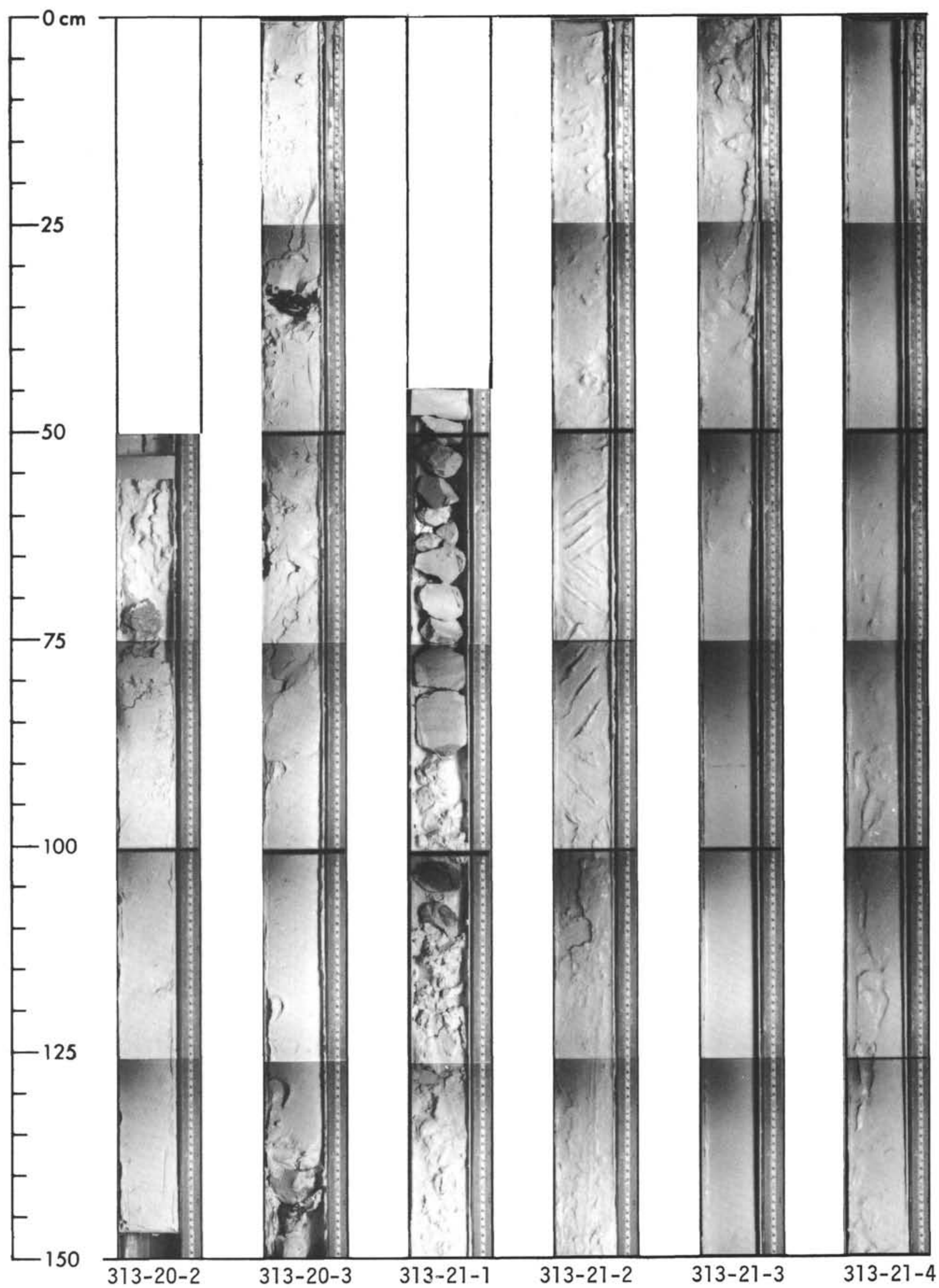




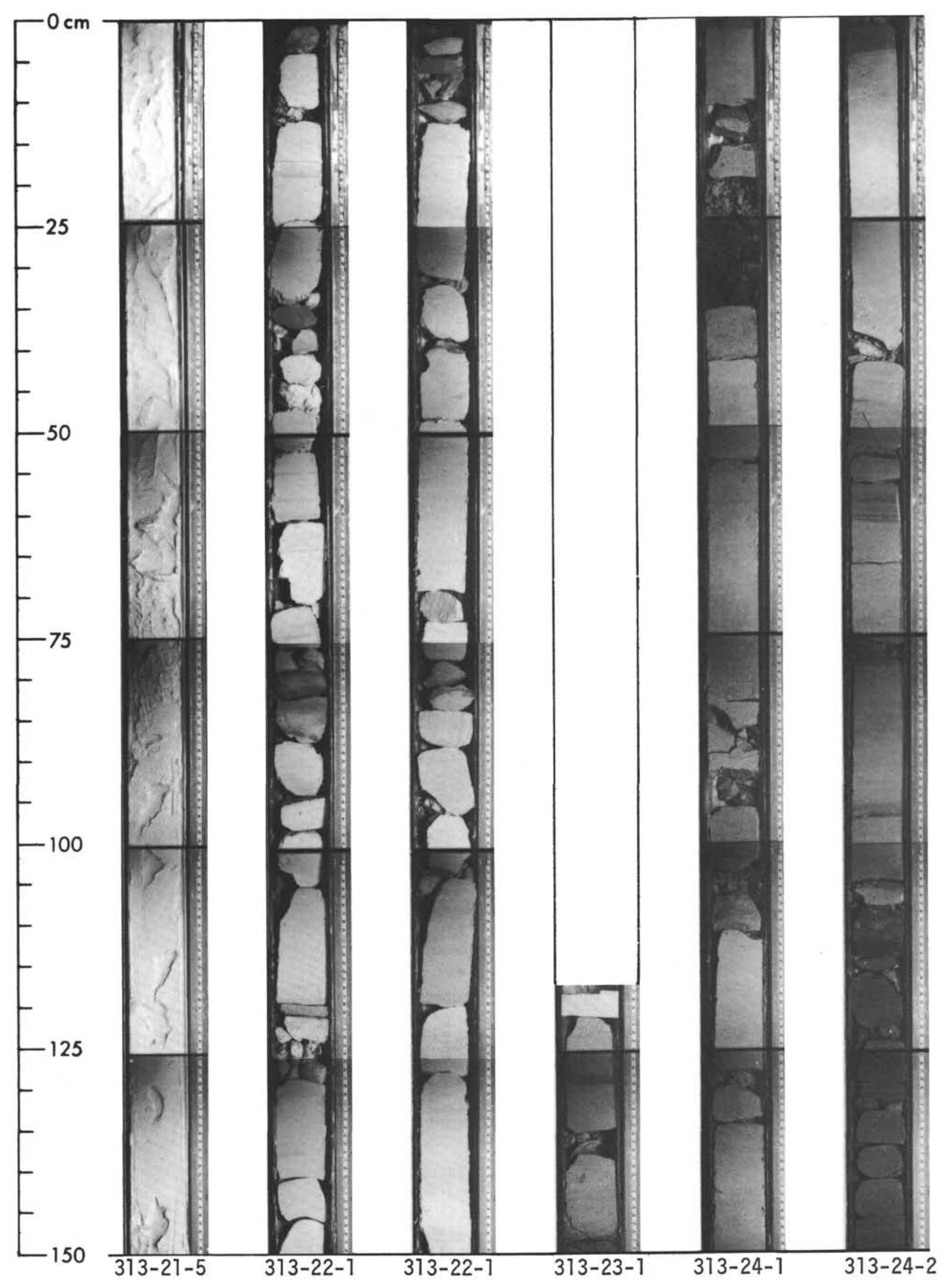




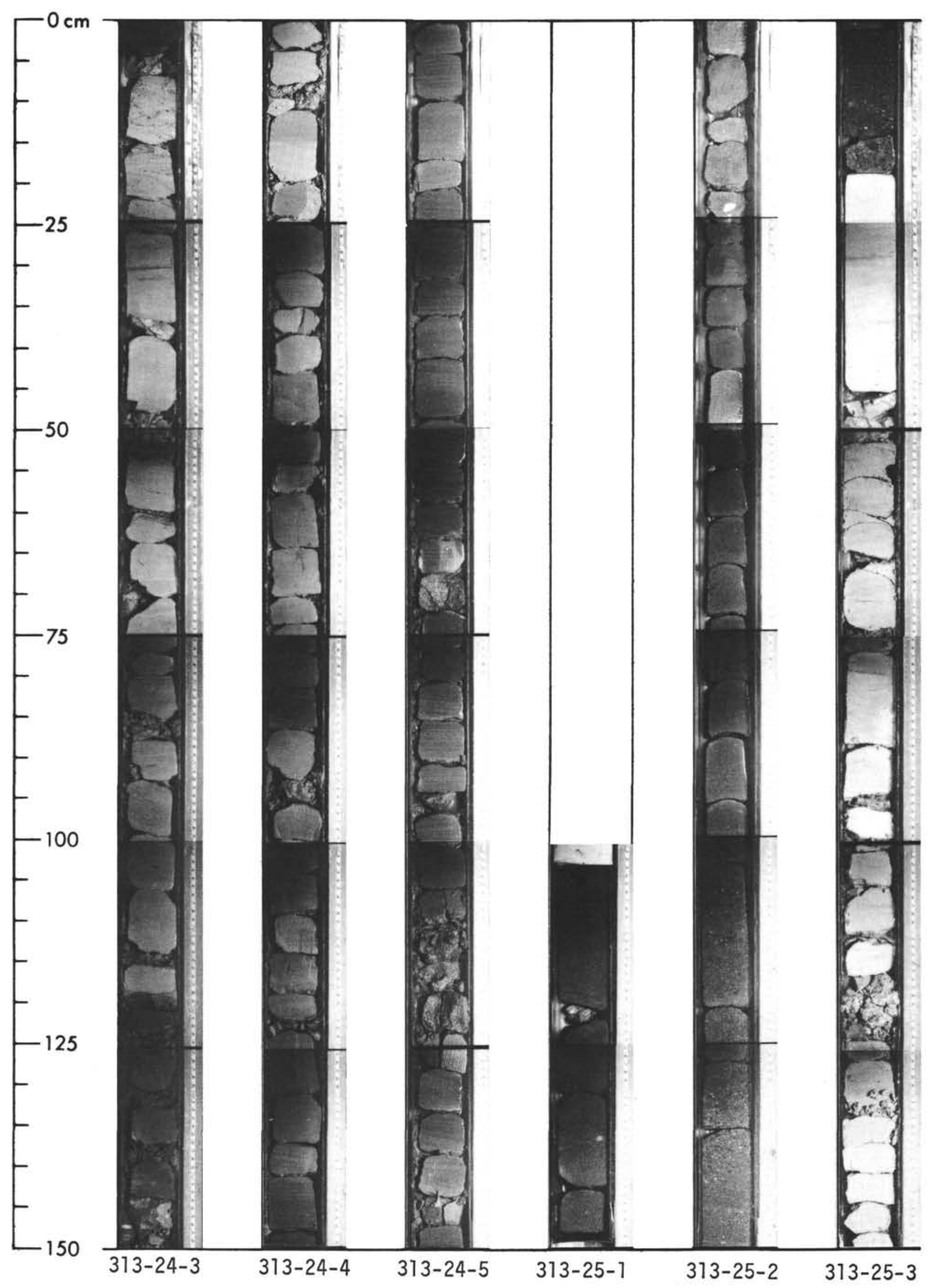




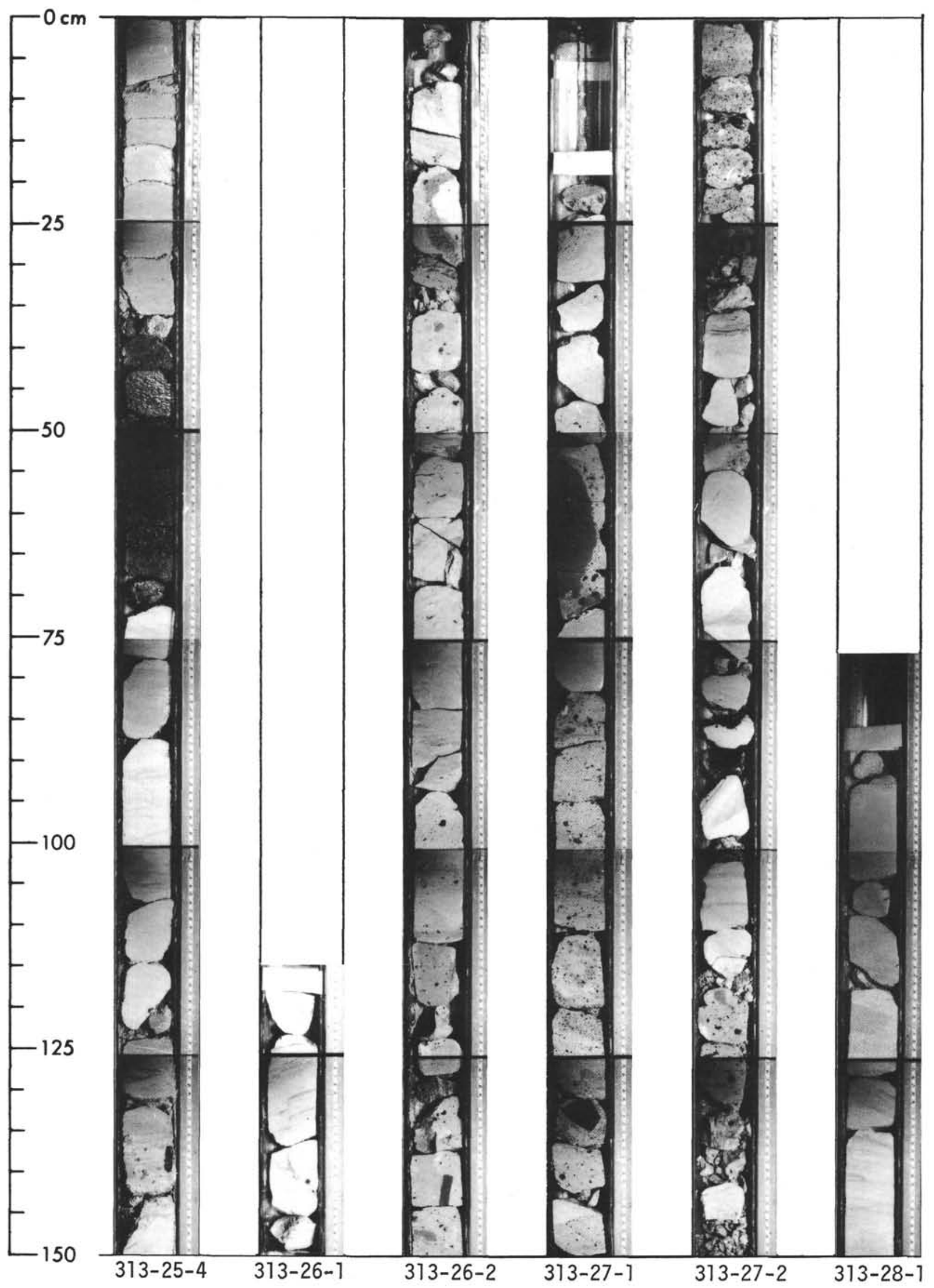




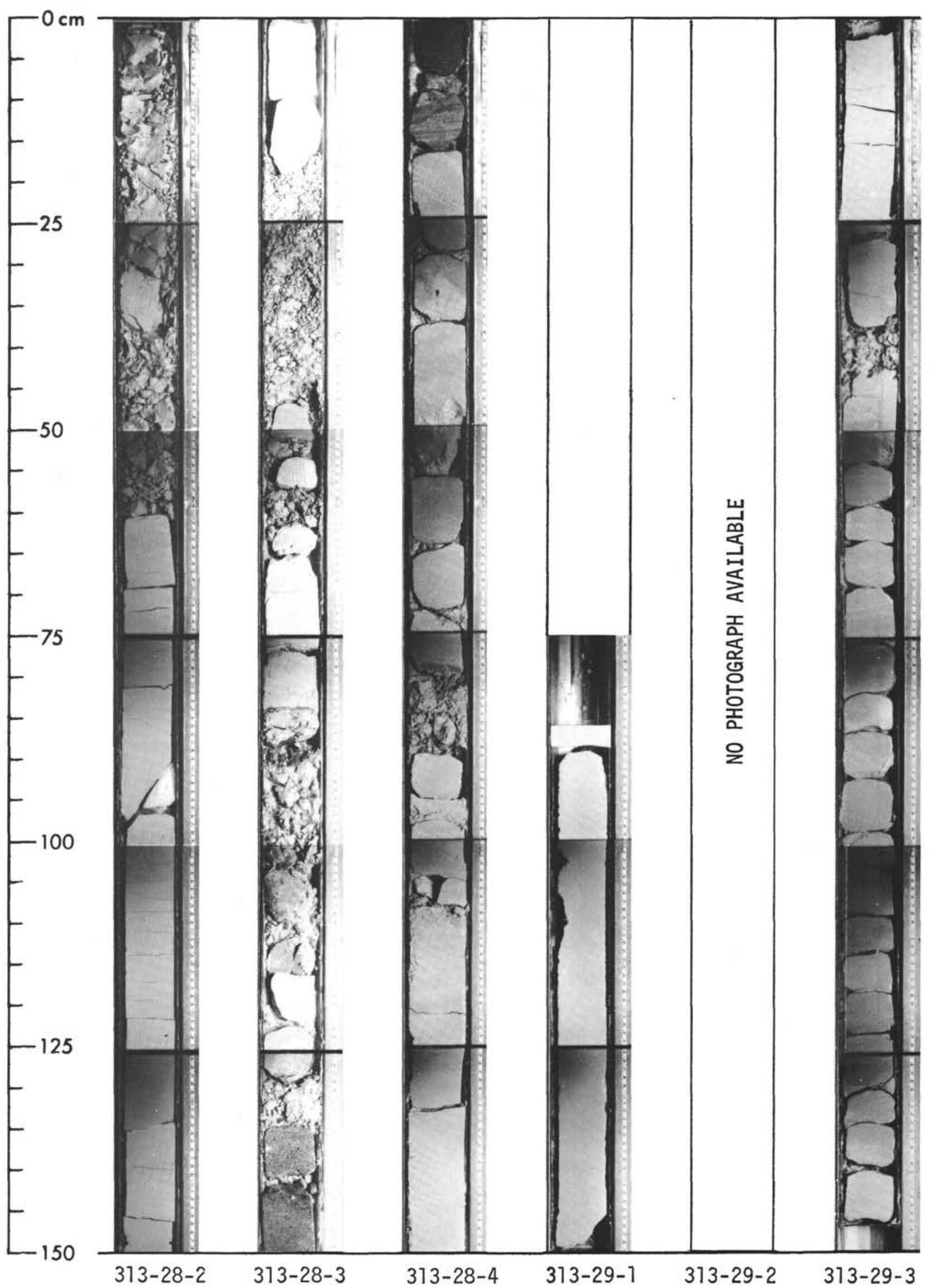




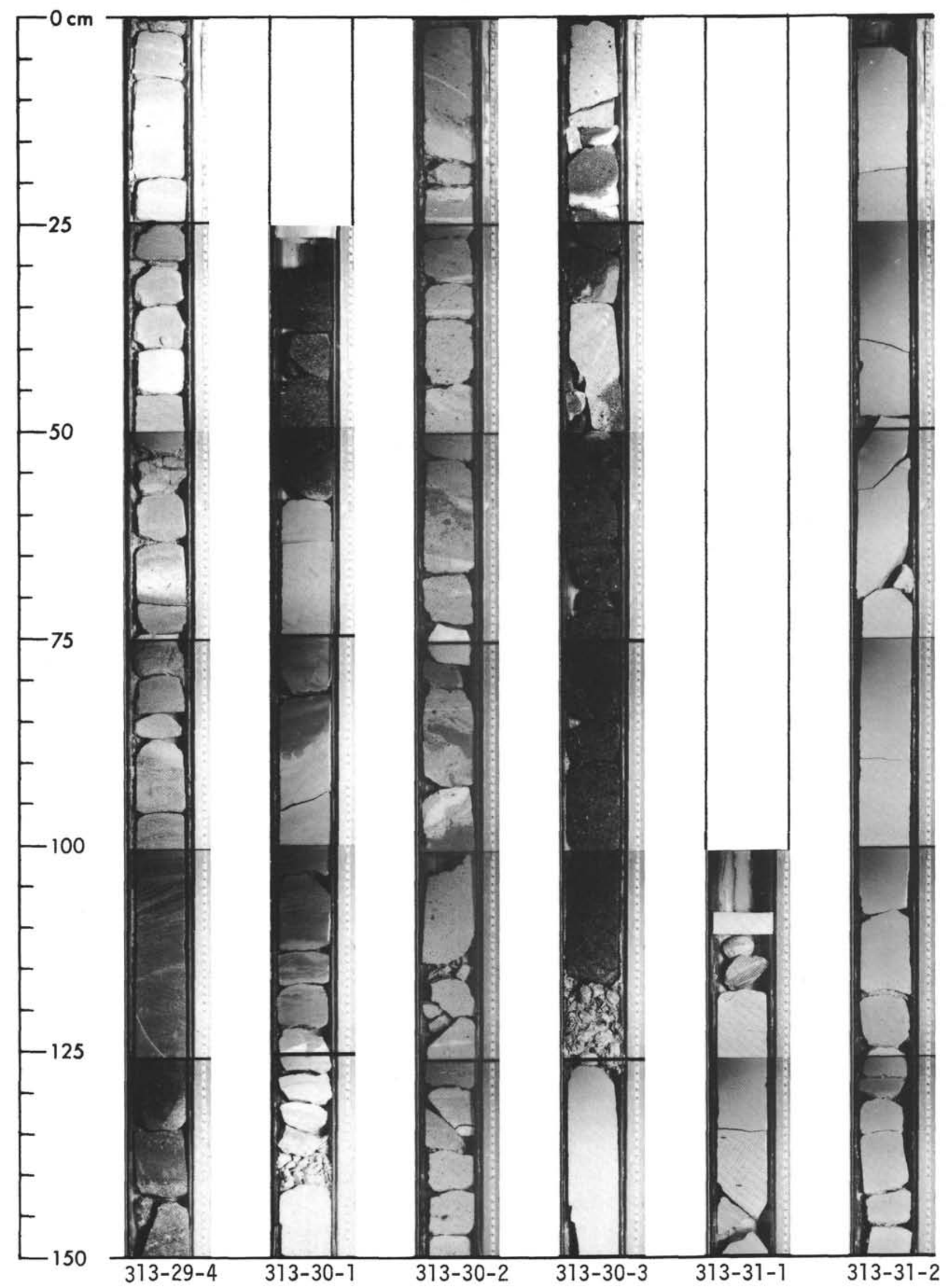




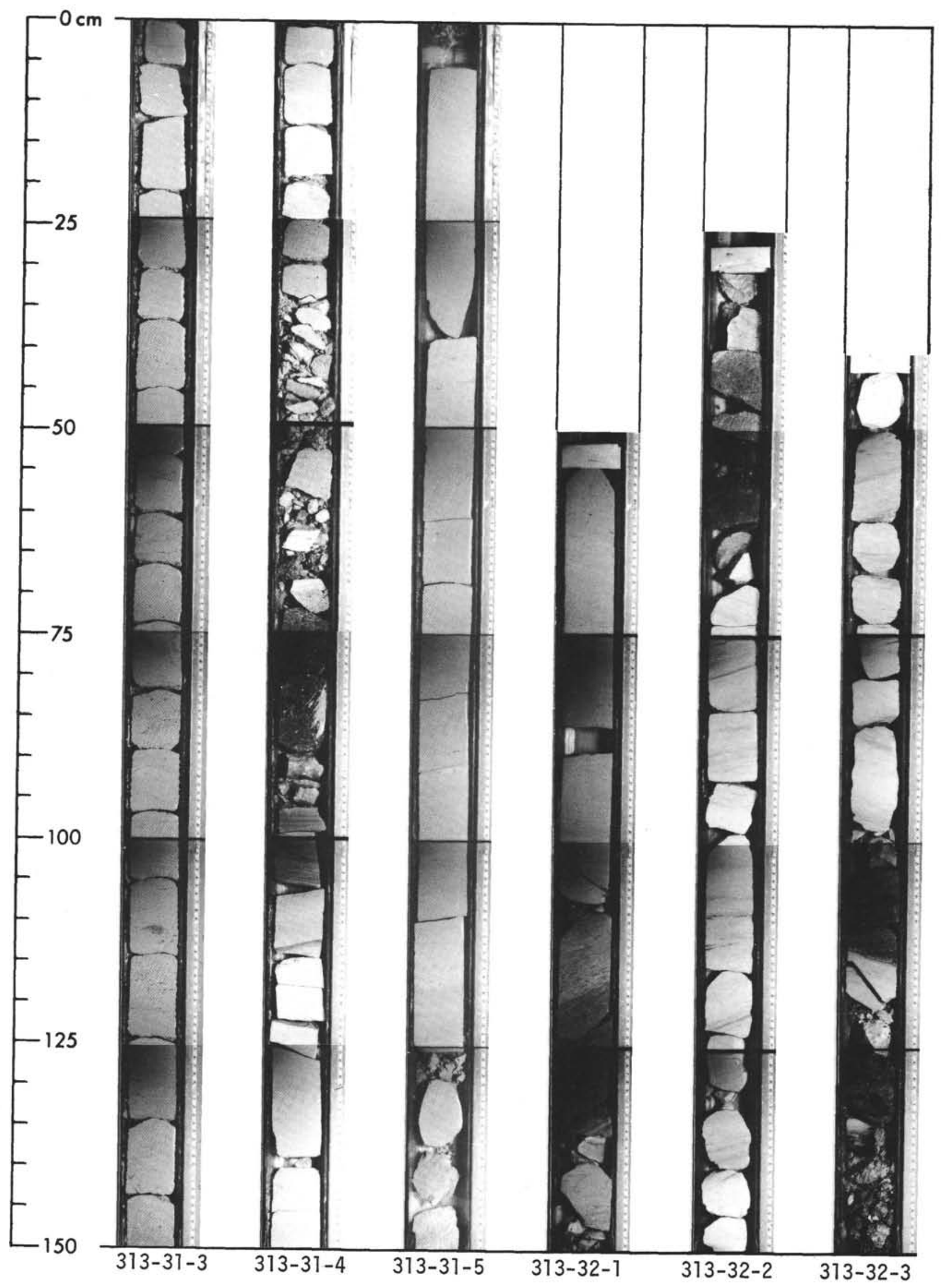




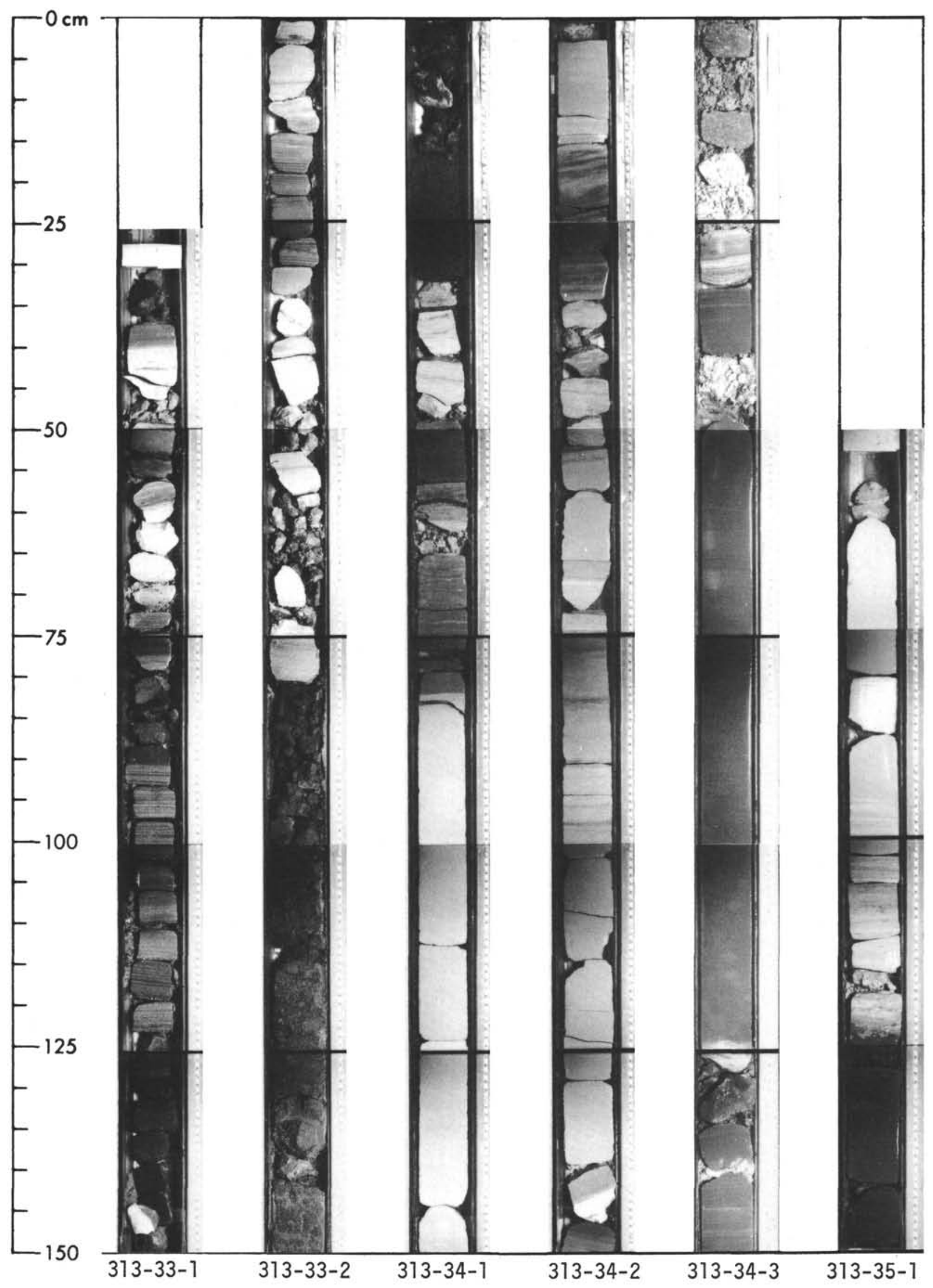




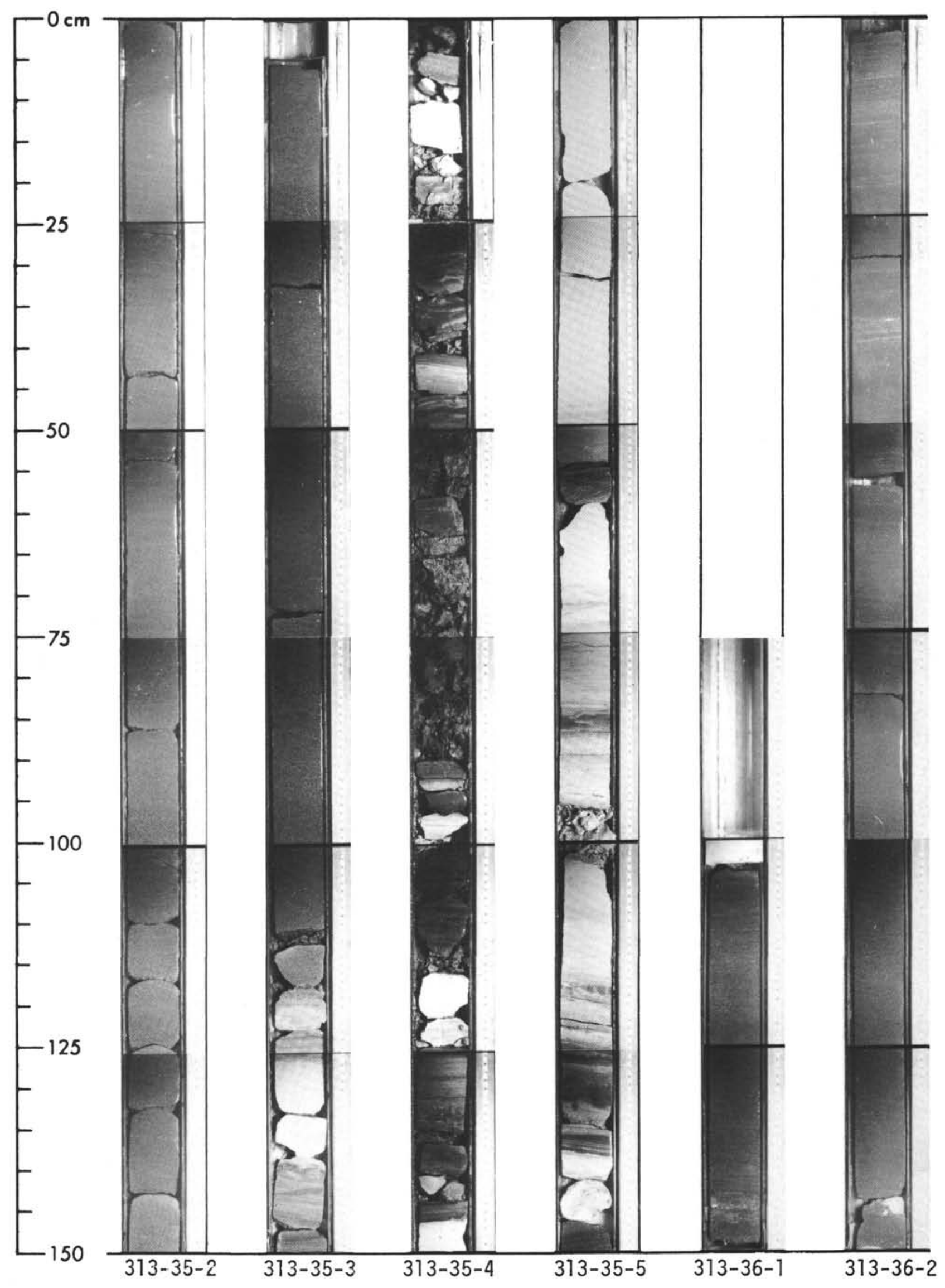


SITE 313

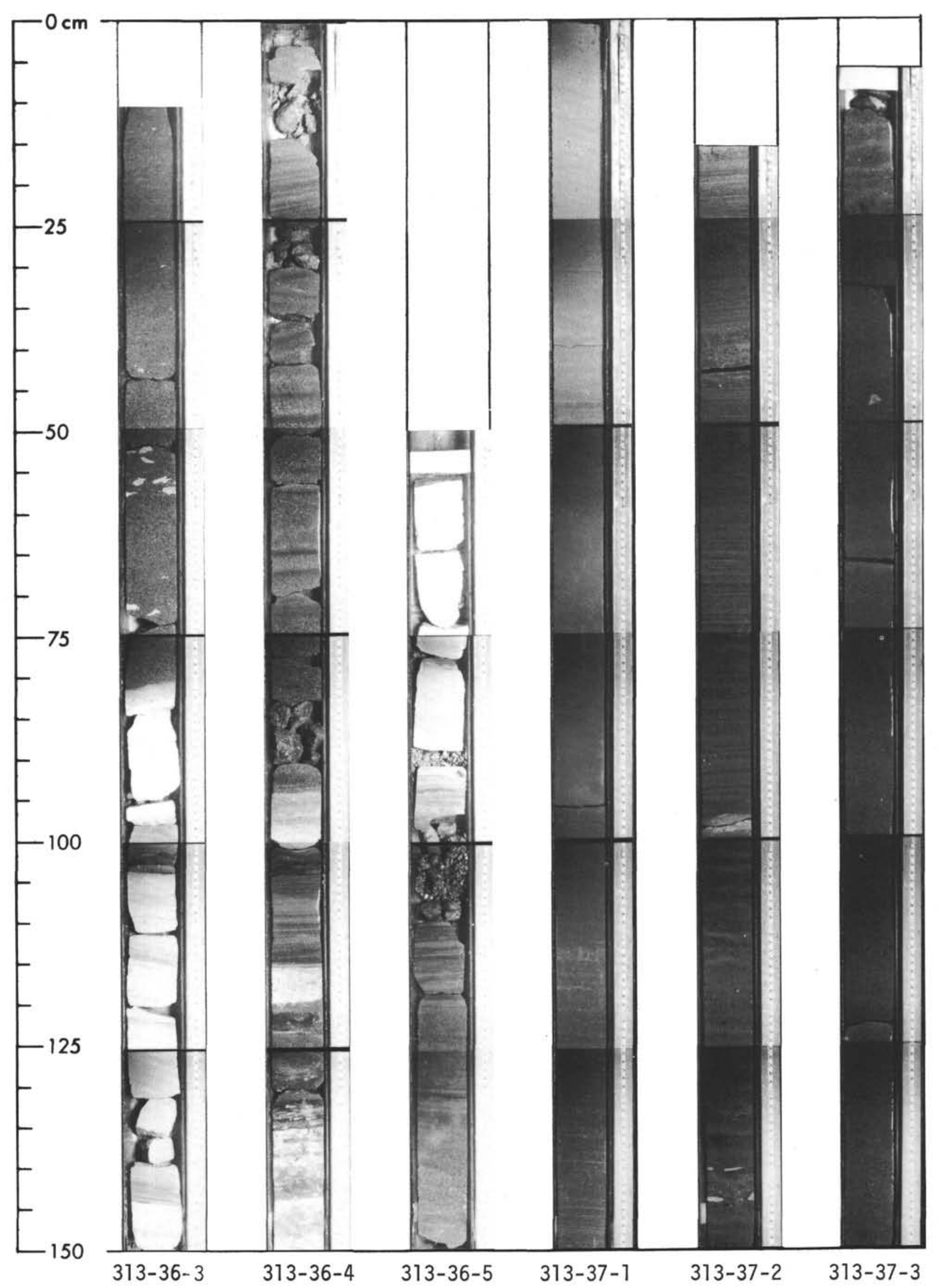




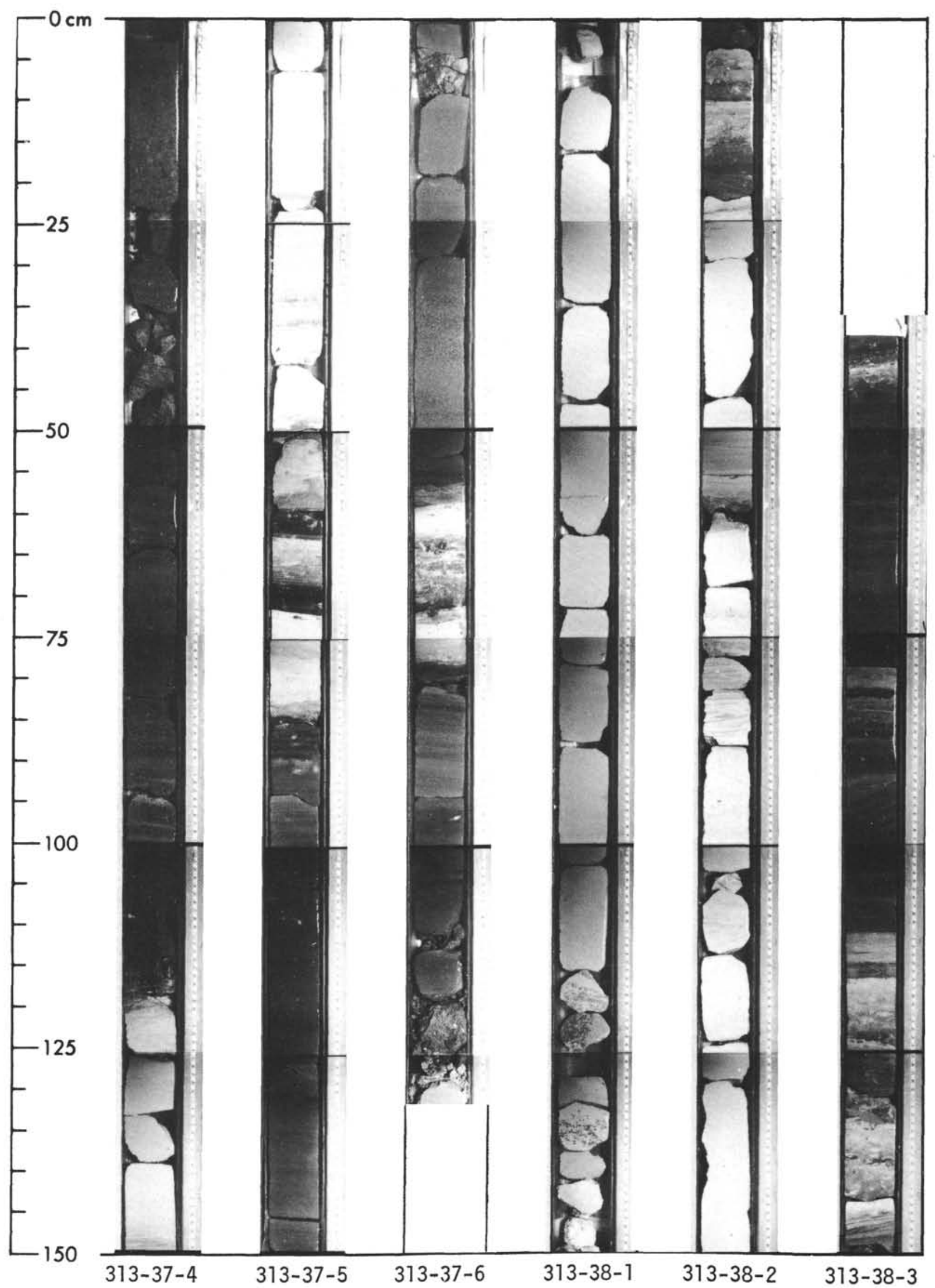




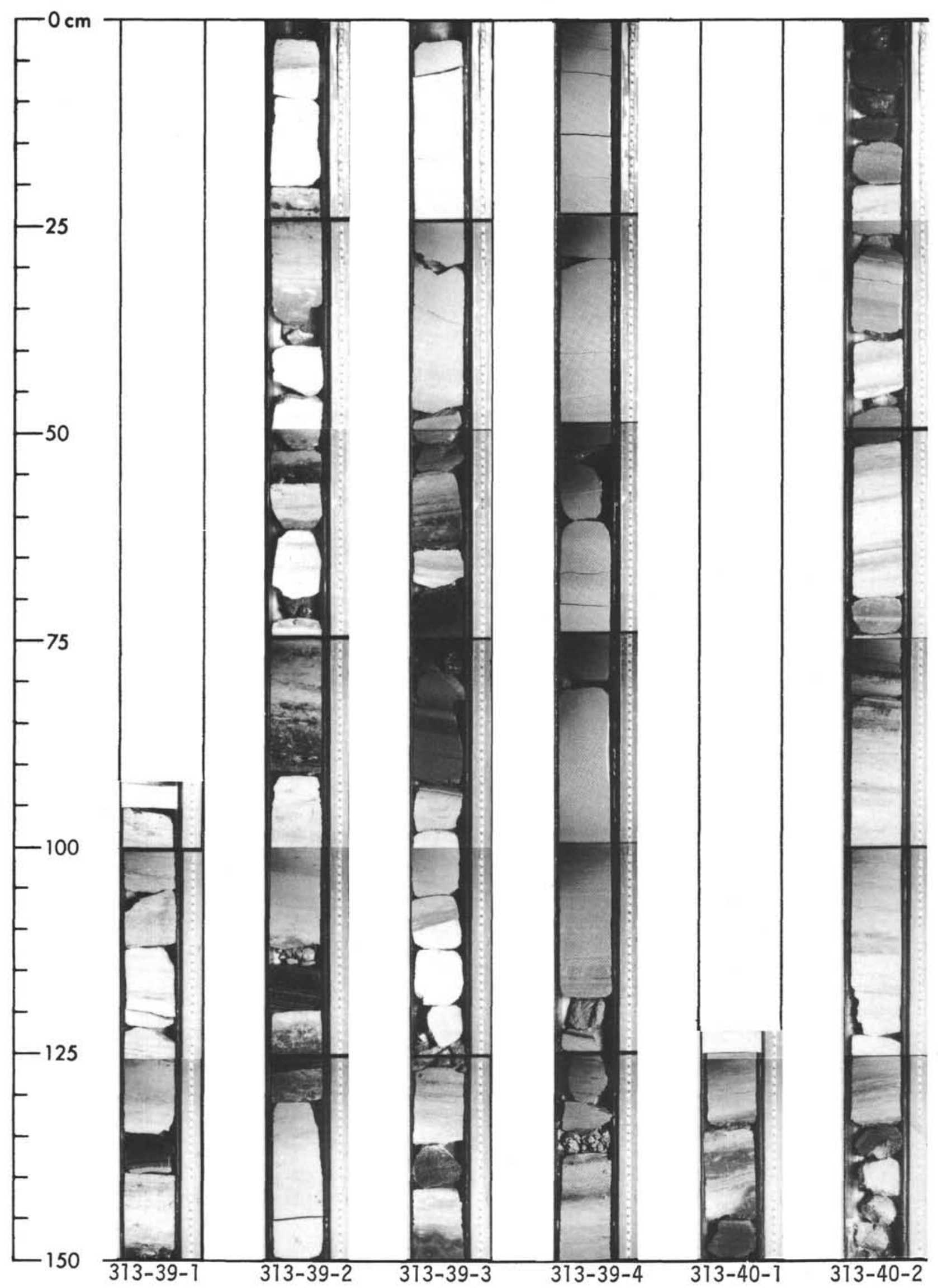




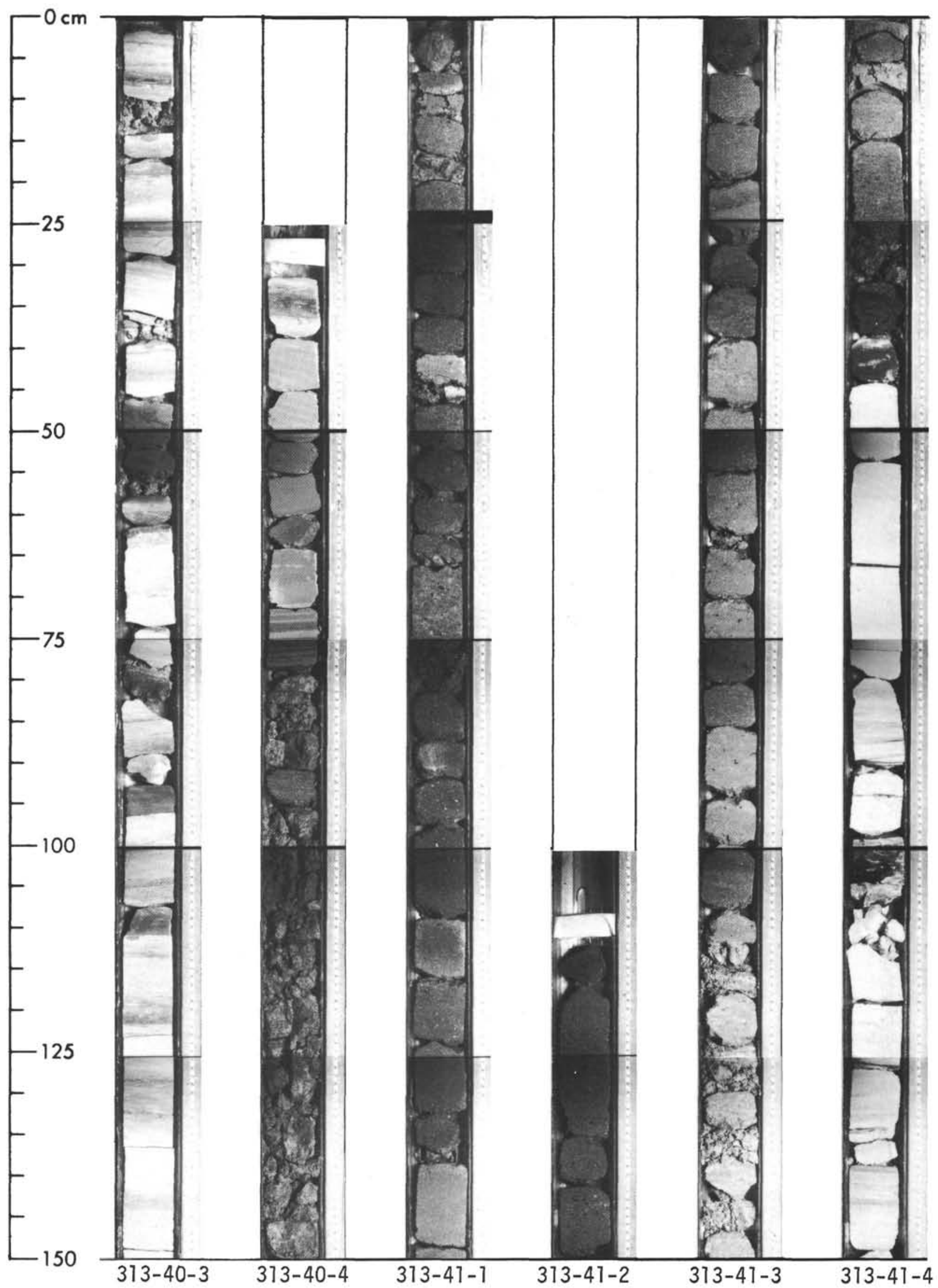




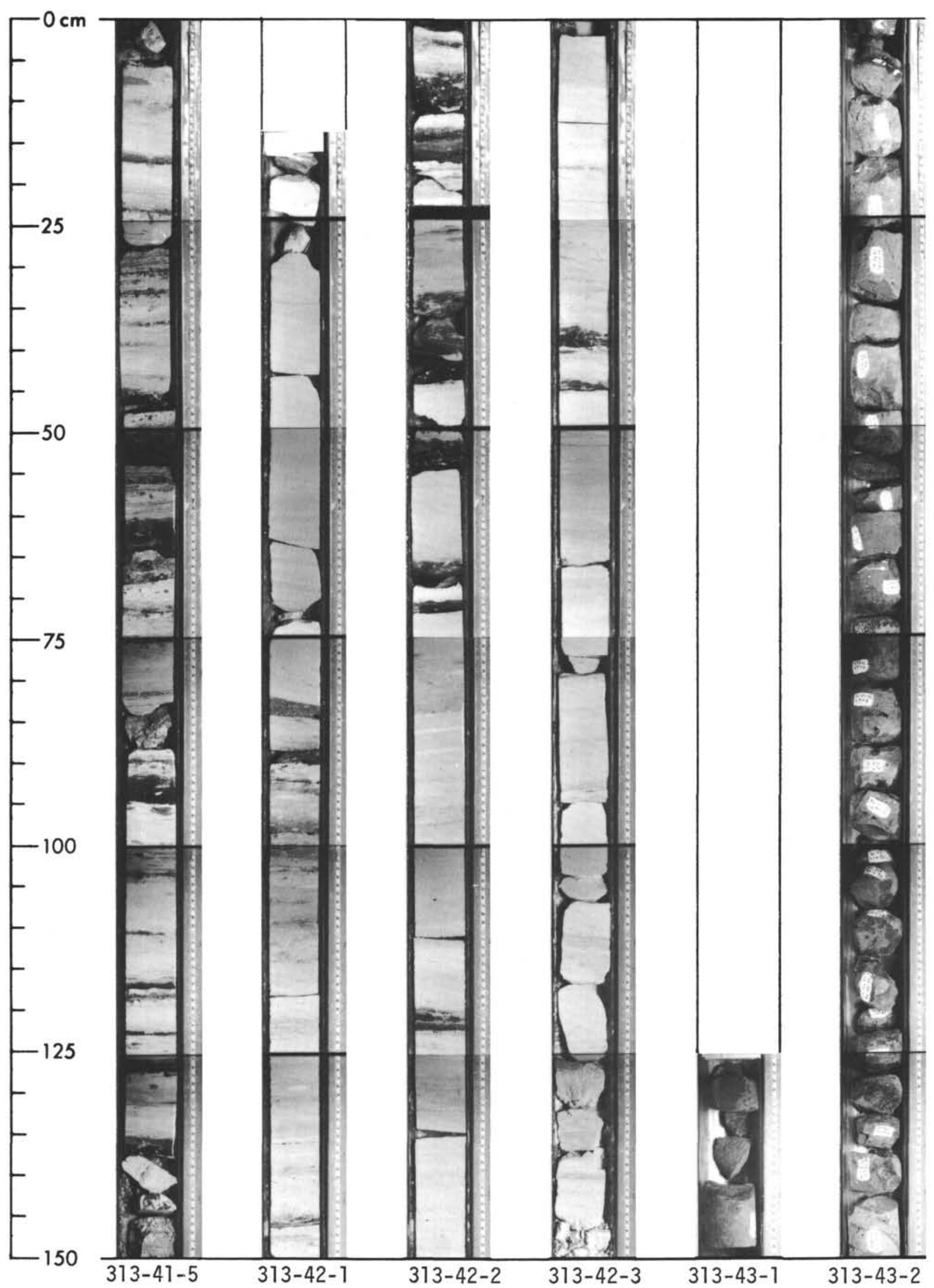




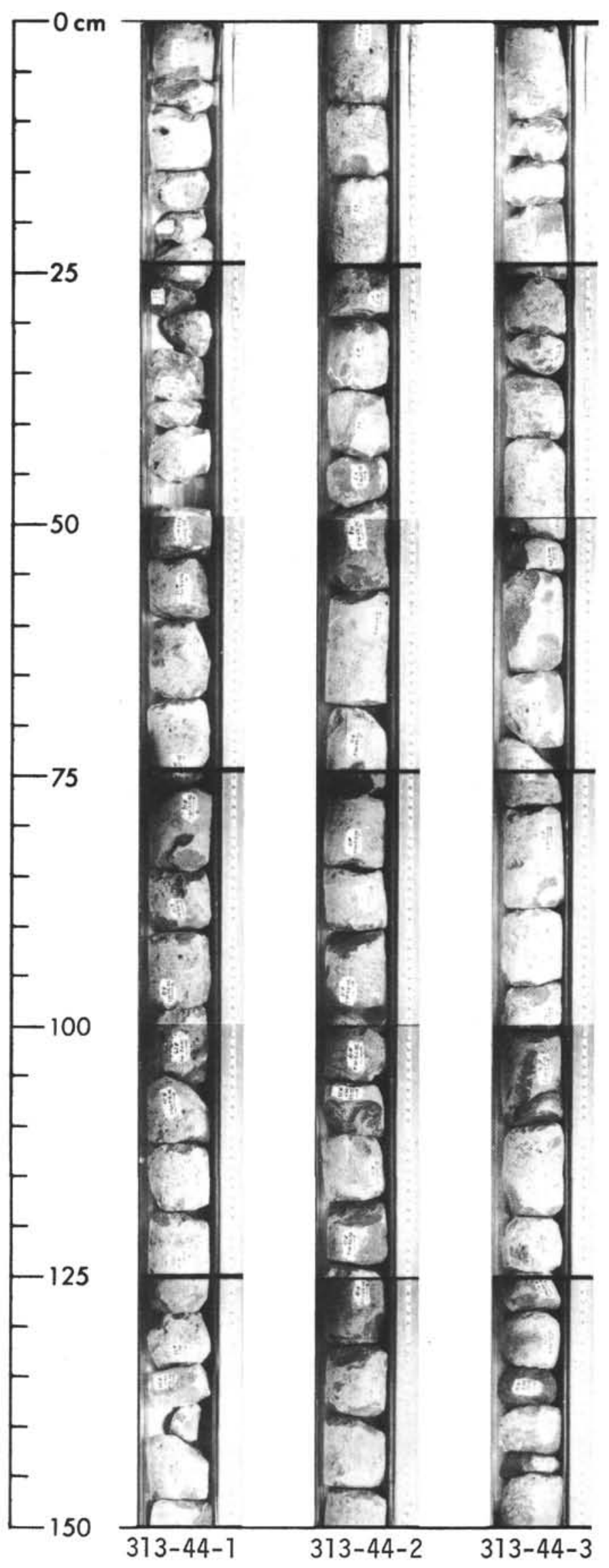

